\author{
UNIVERSIDADE DE SÃO PAULO \\ FACULDADE DE FILOSOFIA, LETRAS E CIÊNCIAS HUMANAS \\ DEPARTAMENTO DE GEOGRAFIA \\ PROGRAMA DE PÓS-GRADUAÇÃO EM GEOGRAFIA HUMANA
}

Maria Luisa Rocha Ferreira de Mendonça

Modo Capitalista de Produção e Agricultura:

A construção do conceito de Agronegócio 


\author{
UNIVERSIDADE DE SÃO PAULO \\ FACULDADE DE FILOSOFIA, LETRAS E CIÊNCIAS HUMANAS \\ DEPARTAMENTO DE GEOGRAFIA \\ PROGRAMA DE PÓS-GRADUAÇÃO EM GEOGRAFIA HUMANA
}

\title{
Modo Capitalista de Produção e Agricultura: \\ A construção do conceito de Agronegócio
}

\section{Maria Luisa Rocha Ferreira de Mendonça}

Tese apresentada ao Departamento de Geografia da Faculdade de Filosofia, Letras e Ciências Humanas da Universidade de São Paulo, para obtenção do título de Doutor em Geografia Humana.

Orientador: Prof. Dr. Ariovaldo Umbelino de Oliveira

São Paulo

2013 


\section{FOLHA DE APROVAÇÃO}

Autor: Maria Luisa Rocha Ferreira de Mendonça

Título: Modo Capitalista de Produção e Agricultura: A construção do conceito de Agronegócio

Orientador: Prof. Dr. Ariovaldo Umbelino de Oliveira

Tese apresentada ao Departamento de Geografia da Faculdade de Filosofia, Letras e Ciências Humanas da Universidade de São Paulo, para obtenção do título de Doutor.

Área de Concentração: Geografia Humana.

Prof. Dr(a).

Banca Examinadora

Instituição: Assinatura:

Prof. Dr(a).

Instituição: Assinatura:

Prof. Dr(a).

Instituição: Assinatura:

Prof. Dr(a).

Instituição: Assinatura:

Prof. Dr(a).

Instituição: Assinatura:

Aprovado em: 


\section{$\underline{\text { Agradecimentos }}$}

Muita gente imagina que escrever uma tese de doutorado é um processo individual, que requer isolamento. Eu também pensava assim. Mas minha experiência na realização deste trabalho me mostrou exatamente o contrário. Esta tese é fruto da colaboração de inúmeras pessoas, algumas bem próximas e outras que ofereceram sugestões quase que por acaso. Quando propomos nos debruçar sobre determinado tema e aprofundar nossa investigação, encontramos apoio e apreciações pelo caminho, algumas propositais e outras inesperadas. É por essa razão que com certeza a lista de agradecimentos será incompleta. Porém, feita a ressalva, gostaria de agradecer algumas contribuições em especial.

No Departamento de Geografia da Universidade de São Paulo encontrei um grupo excepcional de professores e colegas. Agradeço o apoio do meu orientador, Ariovaldo Umbelino de Oliveira, e dos professores Larissa Mies Bombardi, Marta Inez Medeiros Marques, Heinz Dieter Heidemann e Anselmo Alfredo. Foi de extrema importância a convivência com outros colegas da pós-graduação, tanto nas disciplinas quanto no grupo de estudo de $O$ Capital. Agradeço em particular a Fábio T. Pitta e Carlos Vinicius Xavier, com quem realizei pesquisas e publicações, pela troca de ideias e angústias.

No contexto mais amplo, esta tese recebeu influência dos muitos anos de trabalho com movimentos sociais rurais, principalmente com a Via Campesina, o Movimento Sem Terra (MST), a Comissão Pastoral da Terra (CPT), o Movimento dos Atingidos por Barragens (MAB), o Movimento de Mulheres Camponesas (MMC) e o Movimento de Pequenos Agricultores (MPA). Outra contribuição essencial partiu da equipe da Rede Social de Justiça e Direitos Humanos, que me proporcionou o respaldo necessário para a realização da pesquisa.

As fontes de referência foram enriquecidas por sugestões de amigos como Mônica Dias Martins, Juca Juliano de Carvalho, Guilherme Delgado, Raj Patel, Peter Rosset, Shalmali Guttal, Kit Miller, Philip McMichael, João Pedro Stédile, Cliff Welch, Biorn Maybury-Lewis, Cleber Folgado, Valter Israel da Silva, Frei Sérgio Görgen, Ricardo Rezende Figueira, Nikhil Aziz, Gerardo Cerdas, Cynthia Vazquez e Miguel Altieri.

Agradeço o apoio de muitas outras pessoas amigas, familiares, que estiveram comigo nessa caminhada. E, de forma especial, sou grata ao carinho do meu filho Luiz que monitorava por telefone todos os meus passos na USP. No trajeto de volta para casa, eu sempre contava com o conforto daquela voz perguntado — você vai demorar? Agora, nem tanto. 


\section{Modo Capitalista de Produção e Agricultura: A construção do conceito de Agronegócio}

\section{$\underline{\text { Resumo }}$}

Esta tese investiga fatores que exerceram influência na construção da imagem da agricultura no modo capitalista de produção e sua representação através do conceito que passou a ser difundido como agronegócio. O uso deste termo se propagou tanto nos círculos acadêmicos, quanto nos meios políticos e de comunicação. A chamada industrialização da agricultura ocorre principalmente a partir dos anos 1950, em um contexto de crise de superacumulação de capital em nível mundial. No Brasil, este modelo ganha força principalmente a partir dos anos 1960 e combina a grande exploração agrícola com o estímulo ao uso de insumos industriais. É no período marcado pelo caráter monopolista ou imperialista do capital que se observa o processo de industrialização da agricultura, conhecido popularmente como agronegócio. A propriedade monopolista pressupõe a incorporação de todos os momentos da chamada cadeia produtiva, desde o controle sobre matérias primas até a circulação das mercadorias, considerando-se o papel essencial do capital financeiro. A internacionalização deste modelo através da exportação de capitais aprofundou a especialização dos monocultivos em determinados países e a divisão internacional do trabalho, a partir da herança colonial. A função do Estado como principal agente facilitador de financiamento para o agronegócio serve de alavanca para as determinações do capital financeiro. Observamos que a criação do conceito de agronegócio, como forma de gerar uma moldura ideológica para a intensificação da industrialização da agricultura, ocorre em um contexto determinado pela reprodução crítica do capital. Tal análise nos leva a entender a relação dialética entre acumulação e crise, como elementos simultâneos e permanentes na lógica do capital, mesmo que sua manifestação apareça de forma polarizada e cíclica. Desta forma, consideramos que na atual conjuntura de predominância do capital financeiro, ou seja, de dependência do agronegócio em relação ao mercado de dinheiro, seu o principal produto seria a própria dívida.

Palavras-chave: Agronegócio; Industrialização da agricultura; Capital financeiro; Crise de superacumulação; Dívida. 
Agriculture in the Capitalist Mode of Production: The construction of the Agribusiness concept

\section{$\underline{\text { Abstract }}$}

This thesis investigates factors that influenced the construction of the image of agriculture in the capitalist mode of production and its representation by the concept that was disseminated as agribusiness. The use of this word became common in academic and political spheres, as well as in the media. The so-called industrialization of agriculture was more prevalent particularly after 1950's, in a context of a crisis of over-accumulation of capital internationally. In Brazil, this production model was supported especially after 1960, and combined large plantations with the use of industrial inputs. The historical period identified as imperialist and characterized by monopolist capital coincides with the process of agriculture industrialization. Monopolist property includes all elements of the production chain, from the control over raw materials until commodity circulation, considering the role of financial capital. The internationalization of this system through capital export increased monocropping in some countries and the international division of labor, based on their colonial history. The role of the State as the main instrument to provide subsidies to agribusiness functioned as a stimulus to the predominance of financial capital. The concept of agribusiness was created as an ideological framework to intensify the industrialization of agriculture, in a context determined by the critical reproduction of capital. This analysis leads us to understand the dialectical relation between accumulation and crisis, as simultaneous and permanent elements in the logic of capital, even if they appear in a polarized and cyclical form. Therefore, in the current context of predominance of fictional capital, in other words, when agribusiness depends on financial markets, its main product is debt.

Key-words: Agribusiness; Industrialization of agriculture; Financial capital; Crisis of overaccumulation; Debt. 
Agricultura en el Modo Capitalista de Producción y Construcción del Concepto de Agronegocio

\section{$\underline{\text { Resumen }}$}

El estudio analiza los factores que ejercieron influencia en la construcción de la imagen de la agricultura en el modo capitalista de producción y su representación a través del concepto que pasó a ser difundido como agronegocio. El uso de este término se propagó tanto en los círculos académicos, como en los medios políticos y de comunicación. La llamada industrialización de la agricultura se da principalmente a partir de los años 1950, en un contexto de crisis de sobreacumulación de capital a nivel mundial. En Brasil, este modelo se fortalece en especial a partir de los años de 1960 y combina las grandes explotaciones agrícolas con el estímulo al uso de insumos industriales. Así, coincidiendo con un período marcado por el carácter monopolista o imperialista del capital, observamos este proceso de industrialización de la agricultura, conocido popularmente como agronegocio. La propiedad monopólica presupone la incorporación de todos los momentos de la llamada cadena productiva, desde el control sobre las materias primas hasta la circulación de las mercancías, considerándose el papel esencial del capital financiero. La internacionalización de este modelo a través de la exportación de capitales profundizó la especialización de los monocultivos en determinados países, y la división internacional del trabajo, a partir de la herencia colonial. La función del Estado como principal agente facilitador del financiamiento para el agronegocio sirve de palanca para las determinaciones del capital financiero. Observamos que la creación del concepto de agronegocio, como forma de producir un marco ideológico para la intensificación de la industrialización de la agricultura, ocurre en un contexto determinado por la reproducción crítica del capital. Este análisis nos permite entender la relación dialéctica entre acumulación y crisis, como elementos simultáneos y permanentes de la lógica del capital, aunque su manifestación aparezca de forma polarizada y cíclica. De esta manera, consideramos que en la actual coyuntura de predominio del capital financiero, o sea, de dependencia del agronegocio con relación al mercado de dinero, su principal producto sería la propia deuda.

Palabras llave: Agronegocio; Industrialización de la agricultura; Capital financiero; Crisis de sobreacumulación; Deuda. 


\section{SUMÁRIO}

Introdução

06

Capítulo 1 - Agricultura no modo capitalista de produção..................................... 13

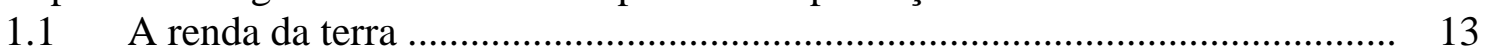

$1.2 \quad$ A propriedade da terra ....................................................................... 19

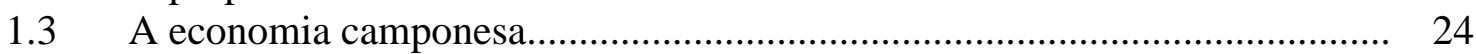

Capítulo 2 - Crise-Acumulação no modo capitalista de produção.............................. 34

2.1 A industrialização da agricultura ............................................................. 34

2.2 O Imperialismo como mecanismo de acumulação capitalista .................... $\quad 40$

2.3 Capital financeiro e monopólios agroindustriais ....................................... 46

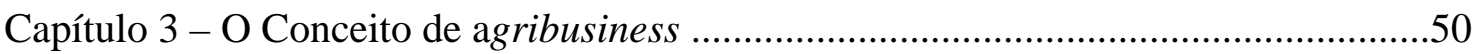

3.1 A influência de John Davis e Ray Goldberg como ideólogos do agribusiness ..50

3.2 A Segunda Guerra Mundial e o avanço do agronegócio ....................................54

3.3 A exportação do modelo do agronegócio para a América Latina ........................57

3.4 O período pós-guerra e a crise de superacumulação ............................................66

3.5 A influência da "economia evolucionária" na concepção do agronegócio ........74

3.6 A utilização do conceito de agronegócio no pensamento neo-malthusiano ........82

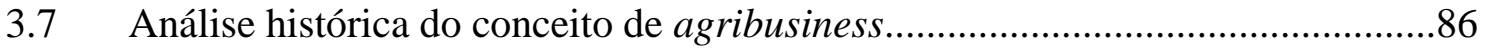

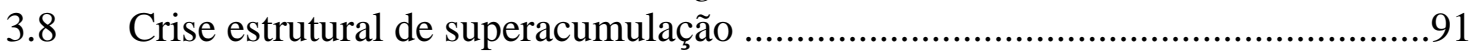

3.9 A "revolução verde" como base ideológica do agronegócio ..............................96

Capítulo 4 - O conceito de complexo agroindustrial .................................................104

4.1 A influência positivista na análise de políticas agrárias ...................................104

4.2 A definição de complexo agroindustrial no contexto brasileiro ........................108

4.3 Política Agro-Pecuária no Brasil de 1960 a 1990: Análise do jornal

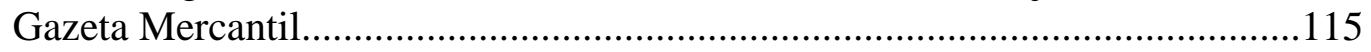

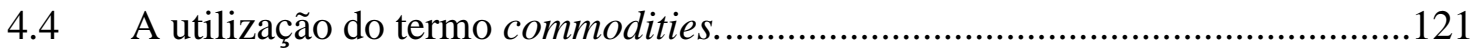

Capítulo 5 - O Conceito de Agronegócio no Brasil .......................................................140

5.1 A concepção das chamadas cadeias produtivas na agricultura ........................140

5.2 A visão neoliberal e o agronegócio ....................................................................144

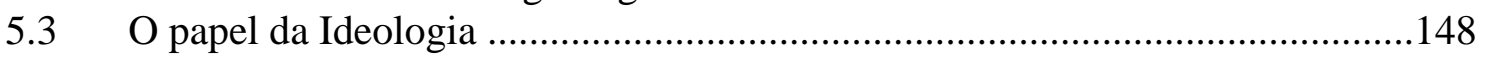

$5.4 \quad$ O uso do termo agribusiness no Brasil .......................................................... 155

Capítulo 6 - A difusão do termo agronegócio no Brasil .................................................166

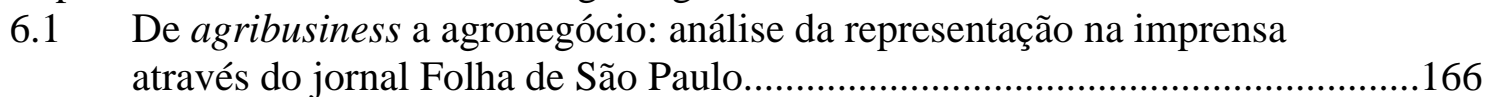

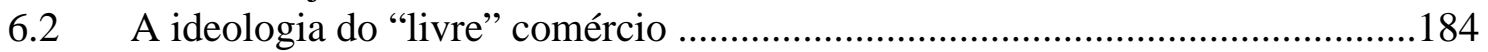

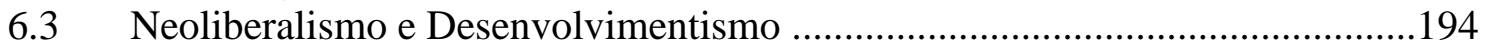

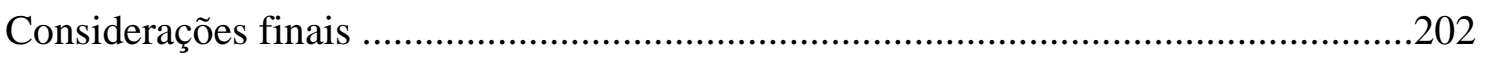

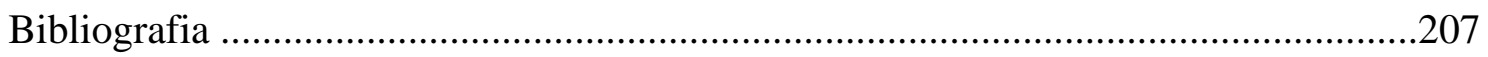




\section{Introdução}

O foco desta tese foi investigar fatores e mecanismos que exerceram influência na construção da imagem da agricultura no modo capitalista de produção e sua representação através do conceito que passou a ser difundido como agronegócio. O uso deste termo se propagou tanto nos círculos acadêmicos, quanto nos meios políticos e de comunicação. A chamada industrialização da agricultura ocorre principalmente a partir dos anos 1950, em um contexto de crise de superacumulação de capital em nível mundial. No Brasil, este modelo ganha força principalmente a partir dos anos 1960 e combina a grande exploração agrícola com o estímulo ao uso de insumos químicos e industriais.

Utilizamos a teoria do valor que embasou o pensamento de Karl Marx em $O$ Capital, ao identificar tendências do modo capitalista de produção a partir de determinadas condições materiais. Nosso estudo inclui o papel da ideologia, entendida no contexto do materialismo dialético como método de análise através do qual Karl Marx e Friedrich Engels reconfiguram o debate filosófico sobre sujeito e objeto, contrapondo-se tanto ao pensamento positivista quanto ao iluminismo idealista, na obra A Ideologia Alemã.

No primeiro capítulo abordamos concepções teóricas sobre a renda da terra com base na compreensão do capital como relação social. A renda da terra assume caráter particular no capitalismo, inserida no âmbito da lógica categorial da forma-mercadoria e do caráter abstrato que a propriedade adquire neste modo de produção. O conceito de propriedade fundiária é utilizado por Marx como abstração que se concretiza em valor mediante a metamorfose da apropriação do trabalho abstrato em lucro ou renda da terra.

De acordo com tal compreensão, o produto da agricultura capitalista é determinado pela busca de realização do valor, entendido no contexto da relação capital-trabalho. É justamente a forma diferenciada de organização do trabalho que se constitui como ponto central no debate sobre a agricultura camponesa. É possível, portanto, partir das categorias fundamentais das relações sociais no modo capitalista de produção para distinguir a chamada unidade econômica camponesa, que tem como principal produto o próprio trabalho camponês. 
É no período marcado pelo caráter monopolista ou imperialista do capital que se observa o processo de industrialização da agricultura, conhecido popularmente como agronegócio. A propriedade monopolista pressupõe a incorporação de todos os momentos da chamada cadeia produtiva, desde o controle sobre matérias primas até a circulação das mercadorias, considerando-se o papel essencial do capital financeiro. A mobilidade do capital faz com que se verifique esse movimento em nível mundial, mesmo com algumas características distintas, que são determinadas por um processo de territorialização a partir da apropriação da renda da terra nos moldes capitalistas.

A formação de monopólios demonstra que a contradição inerente à composição orgânica do capital (constante e variável) não se dá a partir de um desenvolvimento mecânico e linearmente crescente, como se força produtiva significasse avanço tecnológico. Esta interpretação reforça a ideia dominante de que o capital constante se constituiria a partir de investimentos ou riscos dos capitalistas. Ao contrário, Marx desvenda o segredo do capital constante, que só pode se formar a partir do trabalho acumulado. Tal análise nos leva a entender a relação dialética entre acumulação e crise, como elementos simultâneos e permanentes na lógica do capital, mesmo que sua manifestação apareça de forma polarizada e cíclica.

No segundo capítulo observamos que a criação do conceito de agronegócio, como forma de gerar uma moldura ideológica para a intensificação da industrialização da agricultura, ocorre em um contexto determinado pela reprodução crítica do capital. A expansão do capital no campo favorece setores industriais, caracterizados pelo monopólio de empresas transnacionais de insumos químicos e máquinas agrícolas. Portanto, a industrialização da agricultura se insere no âmbito da relação contraditória entre crise e acumulação de capital.

A noção linear e progressiva de desenvolvimento permanece na atualidade e é frequentemente utilizada para definir a situação econômica dos chamados países em desenvolvimento. Esta definição gera a impressão de que estes países estariam a caminho de um patamar ideal nos moldes capitalistas; seria somente uma questão de tempo. O processo de desenvolvimento das forças produtivas, particular ao modo capitalista de produção, se expressa através da concorrência entre capitais, porém não deve ser confundido com avanço tecnológico. 
A chamada crise de superprodução não é resultado do subconsumo ou de um suposto desequilíbrio entre oferta e demanda. O que ocorre é um aumento proporcional de capital constante em relação ao capital variável. A busca por valorização gera aumento da composição orgânica do capital, que eleva a produtividade do trabalho, o que significa, ao mesmo tempo, impossibilidade de explorar trabalho impedindo a valorização, já que o trabalho é a única fonte de produção de valor. O Estado, por sua vez, cumpre o papel de mediador de empréstimos bancários e subsídios para o agronegócio, o que representa transferência de trabalho acumulado para financiar insumos industriais na agricultura. A função do Estado como principal agente facilitador de financiamento para o agronegócio serve também de alavanca para as determinações do capital financeiro.

O capítulo três sistematiza os fatores que influenciaram a publicação do livro $A$ Concept of agribusiness, de John Davis e Ray Goldberg, em 1957. O livro traz como premissa central a ideia de que o campo estaria passando por uma "revolução tecnológica”. De acordo com tal perspectiva, seria necessário formular políticas estatais de apoio à grande exploração agrícola e a sistemas de transporte, processamento e distribuição de alimentos e fibras. Como parte do que formaria o chamado agribusiness, os autores incluem proprietários de terra e indústrias, instituições de pesquisa, grupos de lobby, além do aparato estatal.

Os elementos que marcaram a economia estadunidense no período pós-guerra refletem uma situação típica de crise de superacumulação. Na agricultura, o aumento da produtividade de grãos e a crescente demanda por investimentos para cobrir os custos com a mecanização geraram a necessidade da criação de diversas políticas governamentais de subsídios internos e também para exportação. A internacionalização deste modelo através da exportação de capitais aprofundou a especialização dos monocultivos em determinados países e a divisão internacional do trabalho, a partir da herança colonial. Empresas transnacionais passaram a controlar os estoques mundiais de grãos, o que estimulou a especulação financeira com commodities agrícolas.

No sentido de contextualizar a ideologia predominante no período pós-guerra e em particular o discurso em defesa do desenvolvimento do agronegócio, buscamos analisar a influência exercida pela chamada "economia evolucionária", segundo a qual as leis econômicas seguiriam o caminho do desenvolvimento biológico, através do 
progresso tecnológico. Ao contrário de tal perspectiva, nossa análise da relação capitaltrabalho, centrada nas contradições do processo produtivo, revela o movimento de desequilíbrio na composição orgânica do capital na agricultura, com o aumento da parte constante em relação ao trabalho vivo a ser explorado.

Entendemos que a chamada industrialização da agricultura gera aumento do capital constante em relação à possibilidade de exploração de mais-valia. A formação de monopólios é resultado da concorrência capitalista, mas, principalmente, da necessidade de se expandir os ativos das empresas e com isso ampliar sua capacidade de acesso a créditos. Ao mesmo tempo, os processos de fusões e aquisições de empresas do agronegócio expressam o caráter contraditório do modo capitalista de produção, pois acabam por eliminar a concorrência como força motora do desenvolvimento das forças produtivas. Portanto, este movimento será necessariamente crítico, já que indica a impossibilidade de valorização do capital, que passa a depender dos sistemas de crédito e subsídios, ou do capital fictício, para se reproduzir.

No capítulo quatro, descrevemos a utilização do termo complexo agroindustrial no Brasil, que era associado à noção linear de progresso e desenvolvimento, como sinônimos de avanço tecnológico. A partir da década de 1960, a agricultura brasileira torna-se mais dependente do uso de insumos industriais e continua a priorizar o mercado externo. Assim, o setor agrícola no Brasil se constitui como consumidor de insumos industriais, o que significaria aprofundar uma dupla dependência da agricultura em relação à indústria e ao mercado internacional. Geraldo Müller (1989) denomina esta conjuntura de "tríplice aliança", que expõe a articulação entre o capital nacional, o capital internacional e o Estado.

Este cenário acarretou ainda uma dependência crescente do agronegócio em relação ao acesso a créditos para cobrir custos de produção com maquinário e insumos químicos, controlados por empresas multinacionais. Guilherme Delgado (2012) observa que o chamado complexo agroindustrial, atualmente denominado de agronegócio, foi alavancado por um conjunto de medidas estatais que possibilitaram a abertura de linhas de crédito especiais para o setor, o que aprofundou a predominância do capital financeiro na agricultura.

Com a intenção de ilustrar o processo de transformação na agricultura brasileira, realizamos uma pesquisa em veículos de comunicação que foram pioneiros na utilização 
do termo agronegócio. O estudo teve como referência mudanças de linguagem principalmente em relação à palavra-chave utilizada para descrever o modelo agrícola predominante. A análise de reportagens e opiniões contribuiu com nossa compreensão sobre os processos sociais, econômicos e políticos que vieram a gerar a popularização da palavra agronegócio e suas conotações mais frequentes.

No capítulo cinco, verificamos as implicações da associação entre os termos agronegócio e cadeias produtivas, que teve como propósito agregar atividades agroquímicas, industriais e comerciais aos cálculos econômicos da agricultura. A pesquisa abrange principalmente a década de 1990, quando prevalecia a política governamental conhecida como neoliberal. Apesar de justificadas através do discurso em defesa do Estado mínimo, as privatizações de setores estratégicos da economia brasileira representaram maior transferência de mais-valia social para o setor privado através do aparato estatal. Portanto, o suposto Estado mínimo nunca existiu para o capital. Naquele mesmo período, os ideólogos do agronegócio passaram a utilizar o termo agricultura familiar para definir o sistema através do qual pequenos agricultores deveriam fatalmente se integrar às chamadas cadeias produtivas.

No capítulo seis, aprofundamos nossa pesquisa sobre as raízes ideológicas que constituíram o conceito de agronegócio. Na década de 1990, o movimento global do capital financeiro e a especulação nos mercados de futuro e de commodities são facilitados por políticas de ajuste estrutural, identificadas com o modelo econômico neoliberal. Naquele período se estimulam também políticas de abertura comercial, que geram dumping de produtos agrícolas no mercado brasileiro.

Um tema comum entre os ideólogos do agronegócio é o apelo para a redução dos subsídios e pela liberalização dos mercados nos países ricos, ao mesmo tempo em que demandam o apoio estatal para o agronegócio no Brasil. Este tipo de pensamento está presente no lobby exercido pelo agronegócio e organizado através de espaços políticos e instituições de classe, que articulam determinados grupos econômicos para exercer pressão sobre órgãos governamentais.

Identificamos a permanência do discurso sobre a vocação agrícola do Brasil, relacionado com a noção de desenvolvimento como se representasse um processo linear, rumo a um suposto patamar ideal. Este tipo de pensamento pode ser identificado tanto entre os ideólogos do neoliberalismo quanto entre correntes consideradas 
desenvolvimentistas. Da mesma forma, o discurso baseado na defesa do avanço tecnológico na agricultura torna-se conveniente no sentido de conciliar as ideologias desenvolvimentista e neoliberal. Nosso estudo sobre a representação do agronegócio na imprensa brasileira sugere que as ideias de desenvolvimento, crescimento e avanço tecnológico, tendo como significado um movimento progressivo, marca tanto o pensamento das correntes desenvolvimentistas quanto das neoliberais. Ambas defendem apoio estatal para a agricultura extensiva, baseada nas chamadas cadeias produtivas, ou seja, no sistema do agronegócio.

A palavra neodesenvolvimentismo passou a ser utilizada de forma corriqueira recentemente no Brasil, sem que se aprofunde o debate sobre seu significado. A confusão mais frequente acorre quando se tenta adaptar um conceito econômico para descrever o cenário político. Tal visão distorce o conceito de desenvolvimento das forças produtivas analisado por Marx no modo capitalista de produção, essencial para entendermos a crítica à economia política.

Se o objetivo de ressuscitar o termo desenvolvimentismo é definir campos político-partidários, ele se torna inadequado. Como explica Mônica Martins (2008), o termo faz referência ao projeto nacional-desenvolvimentista dos anos 1950, nos moldes da Comissão Econômica para a América Latina (CEPAL), que implantou um modelo econômico baseado no Estado planejado para apoiar o setor privado, com participação do capital estrangeiro, o que veio a gerar a crise da dívida nos anos 1980. Hoje, o papel do Estado mantém a função de transferir mais-valia social para o setor privado, principalmente através da expansão do agronegócio e de projetos energéticos e de infraestrutura, centrados no controle da terra, água e minério. Com o agravamento da crise econômica mundial, principalmente a partir de 2008, verificamos o retorno da aplicação de medidas típicas do período chamado neoliberal.

É possível observar que os elementos que integram os períodos de expansão do agronegócio coincidem com aqueles identificados como determinantes para gerar crise. Por exemplo, o aprofundamento da política governamental que aposta nos mercados de futuro gera maior dependência do agronegócio em relação ao capital financeiro e aumenta a instabilidade no mercado de commodities. Portanto, concluímos que tais fatores de estímulo à acumulação se convertem em limites na realização do produto do agronegócio que seria a valorização de capitais. Desta forma, consideramos que na atual 
conjuntura de predominância do capital financeiro, ou seja, de dependência do agronegócio em relação ao mercado de dinheiro, seu o principal produto seria a própria dívida. 


\section{Capítulo 1 - Agricultura no Modo Capitalista de Produção}

\section{A renda da terra}

Esta tese tem como base a compreensão do capital como relação social, a partir do método materialista dialético que embasou o pensamento de Marx ao identificar tendências do modo capitalista de produção, investigadas a partir de determinadas condições materiais. Uma das categorias centrais em nossa análise sobre o conceito de agronegócio é a renda da terra, cuja compreensão é essencial para definirmos o próprio papel da agricultura no modo capitalista de produção. A renda da terra assume um caráter particular no capitalismo e, por isso, deve ser entendida no âmbito da lógica categorial da forma-mercadoria. Em O Capital, Marx explica que:

A renda só pode se desenvolver como renda monetária com base na produção de mercadorias, ou melhor, na produção capitalista, e ela se desenvolve na mesma medida em que a produção agrícola se torna produção de mercadorias; (...) pois na mesma medida o produto agrícola se torna mercadoria, valor de troca e valor. $\mathrm{Na}$ mesma medida em que, com a produção capitalista, se desenvolve a produção de mercadorias e, por conseguinte, a produção de valor, desenvolve-se a produção de mais-valia e de mais-produto. Mas na medida em que esta última se desenvolve, desenvolve-se a capacidade da propriedade fundiária no sentido de captar, mediante seu monopólio sobre a terra, uma parte crescente dessa mais-valia (MARX, Livro III, Tomo II,1985, p. 139-140).

Marx inicia o livro I de $O$ Capital com a análise da forma-mercadoria, ou seja, a partir da forma mais elementar na qual se expressa a aparência (aparentemente concreta) do capital. Porém, o segredo ou essência da forma-mercadoria só pode ser compreendido a partir de seu conteúdo aparentemente abstrato (valor). Para Marx, "O corpo da mercadoria que serve de equivalente figura sempre como corporificação do trabalho humano abstrato e é sempre o produto de determinado trabalho concreto, útil. Esse trabalho concreto torna-se portanto expressão de trabalho humano abstrato" (MARX, Livro I, Tomo I, 1983, p. 61).

É nesse sentido que a forma valor "oculta uma relação social”, ou seja, esconde a relação entre as classes sociais no capitalismo, na qual o trabalho abstrato se converte em única fonte de valorização, através da mais-valia, na produção de mercadorias (MARX, Livro I, Tomo I, 1983, p. 60). A relação dialética entre essência e aparência ou abstrato-concreto é chave para chegarmos ao fetiche da mercadoria. Para Marx, aparência não significa não-existência, assim como essência não é algo destituído de concretude: "É portanto uma segunda peculiaridade da forma equivalente que trabalho 
concreto se converta na forma de manifestação de seu contrário, trabalho humano abstrato (MARX, Livro I, Tomo I, 1983, p. 61).

A teoria de Marx sobre o valor e a mais-valia, sem a qual seria impossível entendermos a lógica do capital, está baseada na relação capital-trabalho, mesmo que o trabalho se expresse a partir de sua identidade negativa - o não-trabalho. Para Marx, o trabalho humano é uma abstração concreta ("dispêndio de cérebro, nervos, músculos, sentidos, etc.”), que se realiza como medida de produção de valor nas mercadorias, a partir da contradição entre valor de uso e valor de troca:

Ao desaparecer o caráter útil dos produtos do trabalho, desaparece o caráter útil dos trabalhos neles representados, e desaparecem, portanto, as diferentes formas concretas desses trabalhos, que deixam de diferenciar-se um do outro para reduzir-se em sua totalidade a igual trabalho humano, a trabalho humano abstrato (MARX, Livro I, Tomo I, 1983, p. 47).

Por sua vez, o valor das mercadorias aparece não a partir do que realmente é tempo de trabalho abstrato - mas a partir da negação de suas categorias no processo de formação de valor, pois o valor de troca é somente forma de manifestação que ocorre a partir da abstração dos valores de uso no universo das mercadorias ou, ao mesmo tempo, de sua objetivação a partir do trabalho abstrato ${ }^{1}$. A forma valor se expressa a partir de seu caráter fetichista, no preço das mercadorias, através de seu equivalente universal - o dinheiro - que na verdade não tem valor.

Esta contradição está presente na própria constituição do capital e se manifesta tanto na sua forma de reprodução ampliada ${ }^{2}$ como na reprodução simples, através da relação entre valor de uso e valor de troca. A forma-mercadoria, portanto, funciona como modo de apresentação fetichista do capital. O fetichismo pode ser definido como o caráter "fantasmagórico" da mercadoria, que "esconde" o trabalho abstrato e assume a função de garantir sociabilidade ao modo capitalista de produção. Em outras palavras, o

\footnotetext{
${ }^{1}$ Marx esclarece que, "Uma coisa pode ser valor de uso, sem ser valor. É esse o caso, quando a sua utilidade para o homem não é mediada por trabalho. Assim, o ar, o solo virgem, os gramados naturais, as matas não cultivadas, etc. Uma coisa pode ser útil e produto do trabalho humano sem ser mercadoria. Quem com seu produto satisfaz sua própria necessidade cria valor de uso mas não mercadoria (MARX, Livro I,Tomo I, 1983, p. 49).

${ }^{2}$ Em Elementos Fundamentais para a Crítica da Economia Política (Grundrisse), Marx faz referência ao caráter simultâneo do capital em relação à sua composição orgânica no processo de reprodução ampliada: "lo que en un proceso de producción aparece como supuesto de material e instrumento, en el otro es producto, y esta renovación, debe efectuarse de manera constantemente simultánea" (Marx, 1997, p. 273).
} 
fetichismo mantém as relações sociais de classe em um campo de aparente "normalidade", convertendo em aceitável uma irracionalidade que aparece como racional no modo capitalista de produção ${ }^{3}$ (ou funcional, se utilizarmos uma categoria positivista). Para Marx:

(...) a forma mercadoria e a relação de valor dos produtos de trabalho, na qual ele se representa, não têm que ver absolutamente nada com sua natureza física e com as relações materiais que daí se originam. Não é mais nada que determinada relação social entre os próprios homens que para eles aqui assume a forma fantasmagórica de uma relação entre coisas (...) Isso eu chamo o fetichismo que adere aos produtos de trabalho, tão logo são produzidos como mercadorias. (...) Esse caráter fetichista do mundo das mercadorias provém, como a análise precedente já demonstrou, do caráter social peculiar do trabalho que produz mercadorias (MARX, Livro I, Tomo I, 1983, p. 71).

Para desvendar o segredo da mercadoria Marx entendeu que o trabalho abstrato se converte em valor a partir do tempo médio de trabalho de toda a classe trabalhadora. Portanto, todos os tempos individuais de trabalho são abstraídos em um único tempo e, com isso, o próprio tempo é entendido como simultaneidade e não como um decurso linear. Este entendimento é fundamental para desvendarmos o caráter abstrato que o trabalho adquire no capitalismo, já que sua suposta medida, que aparece como tempo de trabalho, se concretiza em valor a partir do lucro médio do trabalho social, como explica Marx:

A força conjunta de trabalho da sociedade, que se apresenta nos valores do mundo das mercadorias, vale aqui como uma única e a mesma força de trabalho do homem, não obstante ela ser composta de inúmeras forças de trabalho individuais. Cada uma dessas forças de trabalho individuais é a mesma força de trabalho do homem como a outra, à medida que possui o caráter de uma força média de trabalho social (MARX, Livro I, Tomo I, 1983, p. 48).

É nesse sentido que, quando Marx se refere à “mudança da força produtiva”, não significa um desenvolvimento linear sucessivo, como muitas vezes é interpretado. Ou seja, o movimento que Marx caracterizou como "desenvolvimento das forças produtivas" não constitui um processo progressivo de "avanço tecnológico" e sim a

\footnotetext{
${ }^{3}$ Esta observação significa que as contradições internas do capitalismo constituem sua própria identidade, como explica Alfredo (2009): "Marx, numa primeira negação da dialética hegeliana - isto é, sem negá-la como superação, mas incorporando-a como método de análise de uma sociedade determinada, a totalidade do capital - tal como conceito sintético universalizador de seus distintos momentos, incorpora, ao contrário, a efetividade das ilusões ou fetiches como condição inalienável da própria efetividade do conceito socialmente definido" (ALFREDO, 2009, p. 382).
} 
determinação dialética que revela a contradição interna do modo capitalista de produção. De acordo com Marx:

(...) à crescente massa de riqueza material pode corresponder um decréscimo simultâneo da grandeza de valor. Esse movimento contraditório origina-se do duplo caráter do trabalho. Força produtiva é sempre, naturalmente, força produtiva de trabalho útil concreto, e determina, de fato, apenas o grau de eficácia de uma atividade produtiva adequada a um fim, num espaço de tempo dado (MARX, Livro I,Tomo I, 1983, p. 52-53).

Tal afirmação nos leva a concluir que a contradição interna da forma-mercadoria não ocorre no tempo como sucessão, mas está presente em sua forma mais simples, como explica Marx: "O segredo de toda forma valor encerra-se nessa forma simples de valor. Na sua análise reside a verdadeira dificuldade" (MARX, Livro I, Tomo I, 1983, p. $54)$.

A contradição inerente à composição orgânica do Capital (constante e variável) não se dá a partir de um desenvolvimento mecânico e linearmente crescente, como se força produtiva significasse avanço tecnológico. Esta interpretação reforça a ideia dominante de que o capital constante se constituiria a partir de investimentos ou riscos dos capitalistas ${ }^{4}$. Ao contrário, Marx desvenda o segredo do capital constante, que só pode se formar a partir do trabalho acumulado. ${ }^{5}$ Marx reitera este debate no livro II de $O$ Capital, quando descreve o capital constante como fruto da mais-valia social acumulada. Ao explicar o papel do capital constante adicional na acumulação e reprodução ampliada, ele afirma que:

O mais-produto, portador de mais-valia, nada custa a seus apropriadores, os capitalistas. Não têm de adiantar, de modo algum, dinheiro ou mercadorias a fim de obtê-lo. (...) O trabalhador, com seu trabalho, não apenas lhes conserva seu capital constante; ele não só lhes repõe o valor-capital variável por uma parte do valor correspondente criada de novo em forma-mercadoria; com seu mais-trabalho fornece-lhes, além disso, a mais-valia existente sob a forma de

\footnotetext{
${ }^{4} \mathrm{Na}$ introdução de Capital, Ernest Mandel esclarece que: "Máquinas nunca poderão, por si mesmas, contratar nenhuma fração da força social de trabalho dispensável, a não ser em ficção científica". Original em inglês: "Machines can never, in and by themselves, hire any fraction of the disposable social labour force, except in science fiction" (1977, p. 52-53).

5 Engels resume a chave para a compreensão do "caráter interno" do modo de produção capitalista: "Essas duas grandes descobertas - a concepção materialista da história e a revelação do segredo da produção capitalista através da mais-valia - nós a devemos a Karl Marx" (ENGELS, 2005, p. 67).
} 
mais-produto. Mediante a venda sucessiva desse mais-produto, eles formam o tesouro, capital monetário potencial adicional. No caso que estamos examinando, o mais-produto consiste de antemão em meios de produção de meios de produção" (MARX, Livro Segundo, Volume II, 1984, p. 361-362).

Principalmente a partir do advento da Grande Indústria, a força de trabalho não pode ser medida apenas através do número de trabalhadores ocupados, já que na lógica do capital o valor é estabelecido pelo tempo médio de trabalho social, ou seja, de toda a sociedade, incluindo sua relação com o trabalho ocioso (tanto o chamado "exército de reserva", quanto o trabalho realmente dispensável em relação ao desenvolvimento das forças produtivas, que significa o tempo excedente entre trabalho necessário e mais trabalho). É nesse sentido que a relação capital-trabalho no processo produtivo será sempre central na análise do modo capitalista de produção, mesmo que ocorram variações na forma de organização do trabalho. O entendimento de Marx sobre a condição social determinante no capitalismo, que concede ao trabalho um caráter de "abstração-concreta" demonstra que:

Nenhum produtor, tanto industrial quanto agrícola, considerado isoladamente, produz valor ou mercadoria. Seu produto só se torna valor e mercadoria em determinado contexto social. Primeiro, à medida que aparece como representação de trabalho social, portanto seu próprio tempo de trabalho como parte do tempo de trabalho social em geral; segundo, esse caráter social de seu trabalho aparece como caráter social impresso em seu produto, por meio do caráter monetário e da permutabilidade geral determinada pelo preço (MARX, Livro III, Tomo II,1985, p. 140).

A definição de trabalho abstrato é fundamental para a compreensão do caráter dialético do modo capitalista de produção. Para Marx, o desenvolvimento das forças produtivas gera aumento do capital constante ou trabalho "morto" (máquinas, infraestrutura, matérias primas, avanço tecnológico, etc.) na composição orgânica do capital e, consequentemente, diminuição do capital variável (trabalho "vivo"). Para compensar este desequilíbrio, ocorre uma oscilação entre a taxa e a massa de mais-valia. O tempo de não-trabalho (que Marx chama de disposable time, em inglês) resultante da substituição do trabalho vivo (capital variável) por trabalho morto (capital constante) gera um limite do capital para com ele mesmo; em outras palavras, uma limitação na sua capacidade de explorar trabalho como fonte da produção do valor.

O desenvolvimento das forças produtivas gera trabalho improdutivo, ou "promessa de trabalho" na versão fetichista da modernização. O método materialista dialético em Marx serve de base para a compreensão da teoria da queda tendencial da 
taxa de lucro na indústria e também da tendência de diminuição da taxa de renda da terra na agricultura capitalista. De acordo com Marx:

Com a queda da taxa de lucro, cresce o mínimo de capital que o capitalista individual precisa ter em mãos para o emprego produtivo do trabalho (...). E, simultaneamente cresce a concentração, pois, além de certos limites, um capital grande com pequena taxa de lucro acumula mais rapidamente do que um capital pequeno com taxa grande. Essa concentração crescente provoca, por sua vez, em certo nível, nova queda da taxa de lucro (MARX, Vol. IV, Livro III, Tomo I, 1988, p. 180).

Tal análise nos leva a entender a relação dialética entre acumulação e crise, como elementos simultâneos e permanentes na lógica do capital, mesmo que sua manifestação apareça de forma polarizada e cíclica. Ou seja, crise é acumulação e acumulação é crise. Mais uma vez, observamos que a lógica do capital se manifesta a partir de seu caráter fetichista - o que aparentemente é acumulação na realidade é crise. Portanto, a crise do capital não se dá pela superprodução ou pelo subconsumo, mas pela impossibilidade de valorização do valor, o que nos faz concluir que sua contradição central se dá no processo produtivo e não na circulação. Esse processo ocorre tanto na composição do capital industrial quanto na agricultura capitalista, que tem como particularidade o potencial de gerar sobrelucro ou renda da terra. Segundo Marx:

Grande indústria e grande agricultura, exploradas industrialmente, atuam conjuntamente. Se, originariamente, elas se diferenciam pelo fato de que a primeira devasta e arruína mais a força de trabalho e por isso a força natural do homem e a última, mais diretamente a força natural da terra, mais tarde, ao longo do desenvolvimento, ambas se dão as mãos, ao passo que o sistema industrial na zona rural também extenua os trabalhadores e, por sua vez, a indústria e o comércio proporcionam à agricultura os meios para esgotamento da terra" (MARX, Livro III, Tomo II,1985, p. 266).

O estudo de Marx sobre a renda da terra pressupõe uma condição especial de monopólio sobre "uma porção do globo terrestre" que é apropriada como propriedade privada. Os elementos gerais de renda diferencial incluem condições particulares naturais ou forças produtivas que não são fruto do trabalho humano como, por exemplo, a fertilidade do solo, fontes de água, minério, entre outras. Em O Capital (Livro III, Tomo II, 1985), Marx explica que o título de propriedade sobre uma parcela do globo terrestre significa que:

Parte da sociedade exige da outra um tributo pelo direito de habitar a Terra, assim como, de modo geral, está implícito na propriedade fundiária o direito dos proprietários de explorar o corpo terrestre, as entranhas da Terra, o atmosfera e, com isso, a manutenção e o desenvolvimento da vida" (MARX, Livro III, Tomo II,1985, p. 238). 
O conceito de propriedade fundiária é utilizado por Marx como uma abstração que, no modo capitalista de produção, só se concretiza em valor mediante a metamorfose da apropriação do trabalho abstrato, que se converte em lucro ou renda da terra. Marx esclarece que:

A propriedade fundiária não gera, portanto, a parte do valor que as transforma [terras e quedas-d'água] em sobrelucro. [...] É a causa, não a criação deste sobrelucro, mas de sua metamorfose para a forma de renda fundiária, e portanto da apropriação dessa parte do lucro, ou do preço da mercadoria, pelo proprietário da terra ou da queda-d'água (MARX, Livro III, Tomo II, 1985, p. 146).

$\mathrm{Na}$ agricultura, elementos da renda diferencial da terra propiciam aos capitalistas condições mais favoráveis para aumentar sua taxa de lucro, ou até obter sobrelucro. Porém, este sobrelucro não é proveniente do capital, mas “do emprego de uma força natural monopolizável e monopilizada pelo capital” (MARX, Livro III, Tomo II, 1985). Essa "força natural", por si só, tampouco é fonte de sobrelucro, mas deve ser entendida como "base natural" de elevação da produtividade do trabalho, considerando-se a realização do valor na forma-mercadoria e a relação dialética entre valor de uso e valor de troca, como observa Marx:

Assim, o valor de uso é sobretudo portador do valor de troca, mas não sua causa. O mesmo valor de uso, caso pudesse ser obtido sem trabalho, não teria nenhum valor de troca, mas continuaria a ter sua utilidade natural como valor de uso (MARX, Livro III, Tomo II, 1985, p. 145).

\section{$\underline{\text { A propriedade da terra }}$}

A análise da renda da terra na obra de Marx, compreendida a partir da metamorfose do trabalho abstrato, nos leva a investigar o próprio caráter abstrato que a propriedade da terra adquire no modo capitalista de produção. De acordo com tal compreensão, o produto da agricultura capitalista, baseado na propriedade privada da terra, é determinado pela busca de realização do valor, entendido no contexto da relação capital-trabalho. A definição de Kostas Vergopoulos esclarece o papel da propriedade da terra no capitalismo:

Se o estudo de toda a agricultura só pode começar pelo solo, é claro que não se trata do solo físico mas do solo-mercadoria, particular ao capitalismo". (...) Crescendo o peso da renda, o capitalismo assume a agricultura como um todo, nela instalando um dispositivo que lhe permite recuperar o máximo do sobretrabalho camponês. O processo de instalação desse dispositivo revela 
processos análogos aos que conhecemos na história sob o nome de "acumulação primitiva" (VERGOPOULOS, 1977, p. 45).

O debate sobre a propriedade da terra no modo capitalista de produção é analisado por Renata Paoliello a partir da relação entre a posse e a instituição da propriedade privada. A autora faz uma análise histórica da posse da terra, que teve origem "nos países da Europa ocidental mediterrânea, pautados pelo sistema jurídicolegal de inspiração romana (“jus civile”), na figura jurídica de omne agro deserto, ou seja, a terra deserta é de todos, de quem a ocupar e cultivar" (PAOLIELLO, 1992, p.2).

Em relação ao contexto brasileiro, Paoliello explica que:

Em 1850, promulga-se a Lei de Terras do Império que visa consolidar a propriedade titular com caráter mercantil predominante, ou seja, recobrir legalmente a terra na prática convertida em valor mobiliário, (...) até então, grandes e pequenos são possuidores, quer dizer, têm assegurado seu direito porque detêm a coisa - a terra - de fato, têm sua propriedade concreta, e não porque têm um direito de propriedade em abstrato, representado em um título negociável. (...) A diversidade das formas de representar e de praticar esse direito possessório como um direito de propriedade é correlata à diversidade dos campesinatos brasileiros, e à variação das formas de propriedade territorial que os definem (PAOLIELLO, 1992, p. 4-5).

Sabemos que a instituição da propriedade privada não é particular somente à atividade agrícola no capitalismo. Assim como as formas categoriais que analisamos anteriormente, como trabalho e valor, a forma de propriedade ou a forma-mercadoria como totalidade, determina este modo de produção. Entretanto, consideramos necessário ressaltar o caráter particular que o monopólio da terra assume no modo capitalista de produção. De acordo com Kostas Vergopoulos, tal particularidade decorre da raridade relativa do fator terra. $\mathrm{O}$ autor esclarece, porém, que seu argumento:

(...) não deve ser concebido num sentido naturalista, mas em suas relações com o universo social do MPC [modo de produção capitalista], que fazem deste monopólio um 'bem econômico', um produto social. A propriedade fundiária moderna é a personificação da terra no MPC, como a propriedade industrial capitalista é a personificação do capital. Não há nada de naturalista em tudo isso. Há, ao contrário, um processo segundo o qual as coisas se convertem em relações sociais (VERGOPOULOS, 1977, p. 57-58).

A partir deste esclarecimento, é possível analisarmos o fator terra como força produtiva, que não provêm do trabalho humano, mas que possui a capacidade de aumentar a produtividade do trabalho (MARX, Livro III, Tomo II, 1985, p. 143) ${ }^{6}$. Nesse

\footnotetext{
${ }^{6}$ Marx explica que "Essa monopolização das forças naturais, ou melhor, o incremento da força de trabalho acarretado por elas, (...) pode elevar a parte do produto do trabalho que representa
} 
sentido, forças produtivas como fertilidade do solo, fontes de água e outros elementos da renda diferencial da terra podem servir como fatores "compensatórios" ou "contrariantes" para minimizar a contradição presente na composição orgânica do capital ou, como já mencionamos, na relação entre capital constante e variável.

Marx define dois tipos de renda diferencial da terra, sempre lembrando que significam a metamorfose do trabalho produtivo em sobrelucro, calculado a partir da diferença entre a taxa média de lucro do capital em geral e a taxa de lucro gerada no pior solo. A chamada Renda Diferencial I inclui determinados fatores como fertilidade e localização da terra, considerando-se propriedades da mesma extensão com o mesmo investimento de capital. Segundo Marx, este tipo de renda diferencial seria:

(...) resultado da produtividade diferente de iguais investimentos de capital em superfícies iguais de fertilidade diferente, de tal modo que a renda diferencial era determinada pela diferença entre o rendimento do capital investido no solo pior, sem renda, e do capital investido no solo melhor (MARX, Livro III, Tomo II, 1985, p. 165).

A Renda Diferencial II acrescenta às condições de fertilidade e localização da terra um volume diferenciado de investimento de capital com o propósito de aumentar a produtividade do trabalho. Marx esclarece que os dois tipos de renda diferencial estão interligados, já que na agricultura capitalista uma proporção maior de capital é geralmente aplicada nos melhores solos. Isso significa que a Renda Diferencial I pressupõe "diferenças na distribuição de capital (e na capacidade de crédito)", ao mesmo tempo em que, acrescentando-se a Renda Diferencial II, o resultado "faz com que capitais investidos no solo deem resultados ou produtos desiguais" (MARX, Livro III, Tomo II, 1985, p 167).

$\mathrm{Na}$ atualidade, estes elementos nos permitem averiguar as determinações do movimento de apropriação da renda da terra pelo capital como parte da contradição crise-acumulação. Na medida em que a agricultura se torna mais extensiva, com a disseminação do modelo conhecido como agronegócio, aumenta a necessidade de investimentos em insumos industriais e também em meios de transporte para comercialização em grande escala. Contudo, através deste mesmo processo, a renda da terra tende a diminuir já que normalmente os maiores investimentos de capital são feitos nos solos mais férteis, eliminando do mercado regulador da taxa média de lucro as

mais-valia em relação à parte que se transforma em salários" (MARX, Livro III, Tomo II, 1985, p. 143). 
propriedades menos produtivas e, consequentemente, diminuindo a lucratividade das mais produtivas.

O aumento do custo de produção e da produtividade do trabalho gera, portanto, uma tendência de diminuição da renda da terra. Esta constatação é fundamental no sentido de esclarecer que chamada crise de superprodução não significa abundância de mercadorias e falta de mercados consumidores. Em outras palavras, não se constitui como um simples problema de relação entre oferta e procura, como muitas vezes é interpretada. A situação de crise de superprodução ou de superacumulação ocorre a partir de uma contradição própria do modo capitalista de produção, determinada pela tendência através da qual o desenvolvimento das forças produtivas diminui a capacidade de valorização do valor, ou seja, da capacidade de exploração de trabalho vivo em relação ao emprego de capital constante no processo produtivo. Sobre este ponto, Vergopoulos (1977) esclarece que, "Segundo o raciocínio marxista, o preço do mercado agrícola crescente não implica num aumento de valor, já que apenas o trabalho vivo cria valores. A propriedade fundiária é apenas uma relação que permite captar valores criados pelo trabalho" (VERGOPOULOS, 1977, p. 58).

Quando Marx explica a metamorfose do sobrelucro em renda fundiária fica claro que o sentido é contrapor-se à visão positivista ${ }^{7}$ de desenvolvimento das forças produtivas. A interpretação positivista imagina que Marx, ao invés de estabelecer uma teoria científica sobre o valor no capitalismo, tivesse defendido a contínua valorização do valor como processo sucessivo natural de chegada ao socialismo. Mais uma vez, lembramos que o autor identifica um processo semelhante ao da queda tendencial da taxa de lucro na indústria, já que entende o modo capitalista de produção como um momento histórico. A propriedade privada nos moldes capitalistas é vista por Marx como abstrata e transitória, já que a "fonte material do título" sobre a terra são as relações de produção, que tendem a transformar-se:

(...) a propriedade privada de certos indivíduos sobre o globo terrestre parecerá tão absurda quanto a propriedade privada de um ser humano sobre o outro. Mesmo uma sociedade inteira, uma nação (...) em conjunto não são proprietárias da Terra. São apenas possuidoras, usufrutárias dela, e (...) devem legá-la melhorada às gerações posteriores (MARX, Livro III, Tomo II, 1985, p. 239).

\footnotetext{
${ }^{7}$ Michael Löwy explica que o positivismo pressupõe que "a sociedade é regida por leis naturais", (LÖWY, 2009, p. 19) e, portanto, não pode ser confundido com o método materialista dialético elaborado por Marx.
} 
O caráter ao mesmo tempo extensivo e intensivo que a agricultura capitalista adota com o modelo do agronegócio pressupõe a combinação entre o latifúndio e a dependência de insumos industriais. É a redução da taxa de lucro na indústria que determina a tendência do capital em migrar para ramos menos produtivos, como a agricultura, no sentido de obter lucro suplementar. Por sua característica monopolista, a renda da terra gera condições especiais de produção que permitem transferência de valor para capitais com uma composição orgânica mais elevada.

Ao considerarmos a contradição inerente à forma-mercadoria no âmbito dos elementos da renda diferencial como determinantes na tendência de superacumulação do capital, é possível identificar que a acumulação do capital na agricultura é simultânea à crise. Estes são alguns dos aspectos que iremos investigar na chamada industrialização da agricultura ou na formação do complexo agroindustrial, que passou a ser conhecido como agronegócio. Para isso, será necessário observar em que medida a tendência de crise de valorização do valor na atual fase do capitalismo, determinada também pelo papel do capital financeiro, está relacionada com a renda da terra.

Segundo a concepção de Delgado (2012), o estudo sobre a relação entre o capital financeiro e o mercado de terras é essencial para entendermos a construção do agronegócio:

(...) na formulação original - do capital financeiro na agricultura - a acumulação de capital, sob múltiplas formas de capital, é integrada ao capital aplicado em terras. E nessa integração de capitais, a captura da renda de terra é essencial. Da mesma maneira, a montagem institucionalizada de um sistema de crédito para a agricultura (SNCR) é também essencial ao processo de construção dos complexos agroindustriais e da função dos capitais aí operantes, com clara estratégia de perseguição da taxa média de lucro do capital operante em múltiplos setores e atividades (DELGADO, 2012, cap. 5).

A análise de Delgado (2012) relaciona os elementos da renda diferencial da terra com o papel do capital financeiro e mostra como foi necessário criar um sistema especial de crédito para tornar possível a industrialização da agricultura no Brasil. Este fato revela o próprio caráter crítico do modo capitalista de produção, que só é capaz de se reproduzir na atualidade a partir da determinação do mercado de dinheiro. O autor esclarece ainda a relação entre a especulação financeira, os mercados de commodities e o mercado de terras. A aparência desta relação fica evidente no preço da terra, que se converte em mera abstração na medida em que: 
(...) é a expressão empírica da expectativa de renda da terra capitalizada, calculada pelos agentes de mercado em cada conjuntura. (...) O processo de relançamento da valorização fundiária, (...) reflete o "boom" de commodities mundiais. E neste sentido, outros mercados nacionais de terras e arrendamentos também o refletem (DELGADO, 2012, cap. 5).

O caráter abstrato que a renda da terra adquire no modo capitalista de produção é desvendado por Marx através da Fórmula Trinitária, que explica tanto o lucro de capital quanto a renda fundiária como formas aparentes da mais-valia:

Lucro de capital (ganho empresarial mais juros) e renda fundiária não são, portanto, nada mais que componentes específicos da mais-valia, categorias em que esta é distinguida conforme ela recai no capital ou na propriedade fundiária, rubricas que, no entanto, não alteram nada em sua essência. Somados, constituem o total da mais-valia social (MARX, Livro III, Tomo II, 1985, p. 274).

\section{$\underline{\text { A economia camponesa }}$}

A descrição de Marx sobre o processo de formação do modo capitalista de produção, ou a Assim Chamada Acumulação Primitiva, contradiz a interpretação de que a passagem do feudalismo para o capitalismo teria ocorrido de maneira etapista, natural ou mecânica. Pelo contrário, a violência é considerada por Marx como principal força produtiva, que se institucionaliza como consenso do que constituiria trabalho produtivo através da “conquista, a subjugação, o assassínio para roubar". Para Marx, este processo serve de alavanca em "todos os momentos em que grandes massas humanas são arrancadas súbita e violentamente de seus meios de subsistência". Tal análise considera que o processo histórico "assume coloridos diferentes nos diferentes países" (MARX, Livro I, Tomo II, p. 261-263).

Marx revela que as categorias essenciais do capital - trabalho abstrato e valor se constituíram a partir da imposição de políticas sistemáticas e abruptas de expropriação da terra e dos meios de subsistência dos camponeses, que foram submetidos a diversas formas de crueldade e tortura, ou condenados à morte, caso não submetessem seu trabalho nos moldes capitalistas. Portanto, a transição do feudalismo para o capitalismo não ocorre de forma natural ou a partir de um processo evolutivo, de continuidade, onde o germe do capitalismo estaria presente na sociedade feudal. Pelo contrário, foi necessária uma ruptura violenta das relações de produção anteriores, que tampouco se deu de forma homogênea em nível mundial. 
Esta observação revela que a lógica permanente de reprodução do capital não ocorre de maneira idílica, tampouco está fora da esfera da contradição. A partir da descrição de Marx, que caracterizou como acumulação primitiva o decorrer histórico de formação do capitalismo, outros autores entenderam que tais mecanismos seriam permanentes na lógica de reprodução do capital. Para Vergopoulos, "A acumulação primitiva não pertence apenas à pré-história, ou à história do capitalismo, mas é também um pressuposto indispensável à recondução cotidiana atual do sistema. Isto é ainda mais válido para o que diz respeito à reprodução ampliada" (VERGOPOULOS, 1977, p. 46).

Tal compreensão nos leva a analisar a permanência de uma parcela significativa da produção agrícola que não é tipicamente capitalista porque não provém do trabalho assalariado. Porém, se considerarmos o modo capitalista de produção como totalidade, concluímos que a produção camponesa não é externa ao capitalismo. A parcela da produção agrícola que não provem majoritariamente do trabalho assalariado é justamente aquela que demanda uma grande quantidade de trabalho e, sendo assim, poderíamos argumentar que não se viabilizaria nos moldes da agricultura extensiva ou do agronegócio. A definição de uma economia camponesa, tipicamente não capitalista, mas relacionada de forma contraditória ao modo capitalista de produção, implica uma concepção do capital como relação social, ou seja, como relação de classe.

Ao desvendar o modo capitalista de produção, Marx parte do papel das classes sociais - "os proprietários de força de trabalho, os proprietários de capital e os proprietários de terra" (MARX, Livro III, Tomo II, 1985, p. 317). Sendo claramente um estudo sobre a lógica do capital, a obra de Marx descreve as relações de classe no capitalismo para chegar ao conceito de trabalho abstrato, ou seja, da própria força de trabalho como mercadoria, que se constitui como base da produção e reprodução do valor:

(...) as mercadorias apenas possuem objetividade de valor na medida em que elas sejam expressões da mesma unidade social de trabalho humano, pois sua objetividade de valor é puramente social e, então, é evidente que ela pode aparecer apenas numa relação social de mercadoria para mercadoria (MARX, Livro I, Tomo I ,1983, p. 54).

Estas mesmas categorias - trabalho abstrato e valor - estão presentes na análise de Marx sobre a renda fundiária. Assim como em outros setores produtivos, a determinação ou o produto da agricultura capitalista é a valorização do capital através 
da apropriação da mais-valia. Este é o segredo revelado por Marx quando propõe a seguinte pergunta:

(...) como é que a terra há de gerar um valor, isto é, um quantum de trabalho socialmente determinado e, ainda por cima, essa parte específica do valor de seus produtos que constitui a renda? A terra atua, por exemplo, como agente de produção na geração de um valor de uso, de um produto material, do trigo. Mas ela não tem nada a ver com a produção do valor do trigo. À medida que o valor se representa no trigo, o trigo é encarado apenas como determinado quantum de trabalho social objetivado (MARX, Livro III, Tomo II, 1985, p. 271).

É justamente a forma diferenciada de organização do trabalho que se constitui como ponto central no debate sobre a agricultura camponesa. É possível, portanto, partir das categorias fundamentais das relações sociais no modo capitalista de produção para distinguir a chamada unidade econômica camponesa. É importante observar que nossa análise não interpreta o conceito de unidade familiar limitando-se à naturalização da forma tradicional da instituição que se padronizou como família, ou como núcleo familiar estabelecido por laços sanguíneos, dotado de normas e hierarquias específicas. Pelo contrário, nossa intenção é identificar uma forma específica de organização do trabalho na produção camponesa que, a partir de uma determinada "unidade de produção", tende a superar o conceito tradicional de núcleo familiar em sua força de trabalho.

Um dos precursores das pesquisas sobre o papel da economia camponesa foi Alexander V. Chayanov, que escreve a obra La Organización de la Unidad Económica Campesina no início do período da revolução russa, quando os camponeses representavam $85 \%$ da população no país. $\mathrm{Na}$ análise sobre a categoria valor na produção camponesa, tanto Marx quanto Chayanov identificaram que uma parte do trabalho excedente dos camponeses é cedida gratuitamente à sociedade. Ao explicar a "gênese da renda fundiária capitalista", Marx descreve tal movimento como: "Uma parte do mais-trabalho dos camponeses que trabalham sob as piores condições é dada gratuitamente à sociedade e nem sequer entra na regulação dos preços de produção ou na formação do valor em geral” (MARX, Livro III, Tomo II, 1985, p. 261).

Chayanov utiliza as mesmas categorias que Marx (trabalho e valor) para entender a forma de organização do trabalho dos camponeses na Rússia. Ele constata que:

(...) a cada queda de preços se seguia um aumento na produção. Este tipo de resposta dos camponeses é uma resposta, digamos assim, tipicamente não 
capitalista. O que se supõe que uma empresa faça quando há uma queda de preços é reduzir a produção (CHAYANOV, 1974, p. 11).

Ao estudar a questão agrária e o capitalismo, Samir Amin retoma este debate ao resgatar o pensamento de Chayanov e utilizar as mesmas formas categoriais que Marx (terra, capital, trabalho) para definir o papel dos camponeses:

(...) um modo de produção camponês, não-capitalista, cujas unidades elementares são constituídas por famílias de camponeses trabalhadores, proprietários do solo, e cujo produto é destinado, principalmente, à autosubsistência da família, estando comercializada apenas uma fração deste. (...) Observa ele que pode-se diferenciar, nesse modo de produção, os 'fatores' da produção (terra, capital, trabalho) (AMIN, 1977, p. 27).

$\mathrm{O}$ autor conclui que, "Falar da economia camponesa da família dos modos pequeno-mercantes não é um contra-senso"; porém, esta afirmação vem acompanhada do seguinte esclarecimento: "o modo camponês não pode ser estudado fora do quadro da formação de conjunto onde está circunscrito" (AMIN, 1977, p. 28-29). Tal observação significa que apesar de não estar isolada das relações sociais capitalistas, a economia camponesa adquire um caráter tipicamente não capitalista.

Historicamente, o trabalho camponês incluiu atividades não agrícolas como a produção de manufaturas, utensílios e ferramentas para uso próprio. Os camponeses também buscaram garantir sua sobrevivência vendendo sua força de trabalho, tanto na agricultura quanto em setores industriais ou nos exércitos. Este tipo de movimento foi interpretado inicialmente por Lênin em seu livro O Desenvolvimento do Capitalismo na Rússia (1899) como se a classe camponesa tivesse uma condição transitória, ou seja, como se seu destino fosse se converter em classe operária ou em uma fração da burguesia. Chayanov, por sua vez, interpretava a diversidade nas formas de organização do trabalho camponês como condição da própria estratégia de reprodução camponesa. É importante notar que Chayanov não considerava sua teoria universalmente aplicável e tampouco pretendeu analisar o destino dos camponeses. Ao mesmo tempo, ele conclui que seria "evidente que dentro dos próximos dez anos a unidade de exploração doméstica camponesa, contudo, continuará sendo um fato inalterável em muitos países, incluindo a U.R.S.S”. (CHAYANOV, 1974, p. 40).

Em 1917, quando escreve $O$ Estado e a Revolução, Lênin descarta o desaparecimento dos camponeses e enfatiza que o processo revolucionário dependeria da participação política das classes proletária e camponesa, afirmando que: "A 
revolução capaz de arrastar a maioria do movimento só poderia ser 'popular' com a condição de englobar o proletariado e os camponeses. (...) Essas duas classes são solidárias, visto que a 'máquina burocrática e militar do Estado' as oprime, as esmaga e as explora" (LÊENIN, 2007, p. 65).

No contexto brasileiro, Otávio Velho aborda a diversidade de formas de definição tanto de camponeses quanto de proletários. No artigo, O Conceito de Camponês e sua Aplicação à Análise do Meio Rural Brasileiro, o autor considera que os tipos abstratos ou "puros" representariam um "caso-limite" e propõe:

(...) a possibilidade de encarar a questão não em termos de oposição pura e simples entre camponeses e proletários, mas como um continuum com dois casos-limite entre os quais teriam de ser colocadas todas as situações em que parceiros, meeiros, arrendadores, etc. podem ser encontrados em nosso interior em graus diversos de autonomia do trabalho (In: WELCH; MALAGODI; CAVALCANTI; WANDERLEY, Org., 2009, p. 95).

É possível derivar algumas questões a partir desta análise como, por exemplo, se a condição camponesa necessariamente se destitui no caso da venda ou da contratação esporádica de força de trabalho pelos camponeses. Em relação ao tipo de cultivo que é priorizado na unidade camponesa, nos perguntamos se o fato de em algum momento se realizar parcialmente o monocultivo subordinado à indústria capitalista destitui a possibilidade de manutenção da categoria como campesinato ou, como entendeu Chayanov, se as variações na forma de organização do trabalho fariam parte da própria necessidade de manutenção da classe camponesa. Em relação a este tema, a obra de Ariovaldo Umbelino de Oliveira nos ensina que:

(...) o processo de desenvolvimento do modo capitalista de produção no território brasileiro é contraditório e combinado. Isso quer dizer que, ao mesmo tempo em que este desenvolvimento avança reproduzindo relações especificamente capitalistas (implantando o trabalho assalariado, através da presença no campo do 'bóia-fria'), o capitalismo produz também, igual e contraditoriamente, relações camponesas de produção (através da presença do trabalho familiar no campo) (OLIVEIRA, 2004, p. 36).

Neste sentido, é importante avaliarmos o papel econômico da agricultura camponesa, seja para o mercado local ou para subsistência, que garante a reprodução tanto dos camponeses quanto dos trabalhadores nos centros urbanos. O papel da produção agrícola local e da agricultura de subsistência é comumente subestimado ou mesmo ignorado nos dados econômicos oficiais, apesar de garantir o sustento da maioria da população no Brasil e em âmbito mundial. No caso brasileiro, o Censo mais 
recente (2006) do Instituto Brasileiro de Geografia e Estatística (IBGE) constatou que, apesar de ocupar apenas um quarto da área agrícola, a agricultura camponesa é responsável pela maioria da produção de alimentos para os mercados locais. Em números, isto representa $87 \%$ da produção de mandioca, $70 \%$ de feijão, $46 \%$ do milho, $38 \%$ do café, $34 \%$ do arroz, $58 \%$ do leite, $59 \%$ de suínos, $50 \%$ das aves, $30 \%$ dos bovinos e $21 \%$ do trigo. A cultura com menor participação da agricultura familiar identificada no censo foi a soja (16\%). Em relação à geração de empregos, 12,3 milhões de trabalhadores no campo estão em estabelecimentos da agricultura camponesa, o que corresponde a $74,4 \%$ do total de trabalhadores no campo. Ou seja, de cada dez trabalhadores no campo, sete estão na agricultura camponesa, que emprega 15,3 pessoas por 100 hectares. No caso da agricultura extensiva, em cada 100 hectares são gerados apenas dois empregos (IBGE, 2006). Em nível internacional, estima-se que cerca de $70 \%$ dos alimentos sejam produzidos por camponeses, que representam cerca da metade da população mundial ${ }^{8}$.

A identificação de relações de produção não capitalistas, considerando-se o modo capitalista de produção como totalidade ${ }^{9}$, pode ser percebida a partir de processos diferenciados de acumulação. O próprio caráter mundial do capitalismo, explicitado com o Pacto Colonial entre a Europa e outros continentes, estabeleceu relações

\footnotetext{
8 "There are 1.5 billion on 380 million farms; 800 million more growing urban gardens; 410 million gathering the hidden harvest of our forests and savannas; 190 million pastoralists and well over 100 million peasant fishers. At least 370 million of these are also indigenous peoples. Together these peasants make up almost half the world's peoples and they grow at least $70 \%$ of the world's food" (ETC Group, 2009, p. 1).
}

${ }^{9}$ Ao abordar a questão metodológica a partir de Marx, Lukács afirma que "o método dialético trata sempre do mesmo problema: o conhecimento da totalidade do processo histórico" (LUKÁCS, 2003, p. 117). Em relação a este tema, Samir Amin esclarece que, "O empirismo apreende o capital a partir dos fenômenos imediatos: os equipamentos em que se cristaliza, as unidades de produção parceladas onde estes equipamentos estão localizados. O hábito da economia convencional de partir da 'microeconomia' reflete, simplesmente, sua incapacidade de compreender que o todo é superior à soma das partes" (AMIN, 1977, p. 16). O conceito de totalidade como constituinte do materialismo dialético é central também na obra de Henri Lefebvre, no sentido de superar as categorias das ciências parcelares que fragmentam o conhecimento: "Quando tentamos particularizar o conhecimento, nós o destruímos por dentro. (...) Se não houver insistência em direção à totalidade, teoria e prática aceitam o 'real' assim como é, e as 'coisas' assim como são: fragmentadas, divididas e desconectadas. Atividades, e consequentemente indivíduos, tornam-se 'reificados' como coisas e, exatamente como coisas, são separados uns dos outros". Original em inglês: "When we try to particularize knowledge, we destroy it from within. (...) If there is no insistence upon totality, theory and practice accept the 'real' just as it is, and 'things' just as they are: fragmentary, divided and disconnected. Activities, and therefore individuals, become 'reified' like things, and, just like things, are separated one from the other" (LEFEBVRE, 2008, p. 181). 
escravocratas, onde o trabalho adquiria condição de mercadoria. A obra de Rosa Luxemburg, A Acumulação do Capital, observa que:

O Capitalismo é a primeira forma econômica com força para propagar-se, uma forma cuja tendência é estender-se a todo o globo terrestre e eliminar todas as outras formas econômicas, não tolerando nenhuma outra a seu lado. Mas ao mesmo tempo é a primeira forma que não pode existir só, sem outras formas econômicas como seu meio e solo alimentador; que, ao mesmo tempo que tende a tornar-se uma forma mundial, sucumbe por sua incapacidade interna de ser essa forma de produção mundial (citação traduzida por LOUREIRO, 2003, p. 20).

Rosa Luxemburg retoma o debate sobre o processo de acumulação do capital em contraposição ao pensamento de correntes positivistas no marxismo, que ignoraram o tema por considerar a reprodução capitalista de forma mecânica e, portanto, determinista. Georg Lukács observa a importância da análise sobre a acumulação trazida por Luxemburg: “Após décadas de vulgarização do marxismo, a obra principal de Rosa Luxemburgo, A Acumulação do Capital, retoma o problema a partir desse ponto" (LUKÁCS, 2003, p. 109). Segundo o autor, a interpretação determinista propagada entre um setor do pensamento marxista gerou a ideia equivocada de que o desenvolvimento das forças produtivas ocorreria linearmente e, portanto, não seria necessário questionar a própria acumulação:

(...) do ponto de vista da economia vulgar, esse problema, com efeito, não deve ser colocado (...) a realidade econômica aparece como governada por leis eternas da natureza. (...) Assim, para a economia vulgar, a questão da acumulação torna-se um detalhe isolado (LUKÁCS, 2003, p. 112).

Entre os autores brasileiros, a interpretação positivista das relações sociais no capitalismo é criticada por Leandro Konder em A Derrota da Dialética. ${ }^{10}$ A obra retoma o debate sobre o papel do sujeito através do conceito de práxis, segundo o qual o trabalho humano teria um duplo papel, como abstração (alienação) no processo produtivo, porém com potencial gerador de consciência crítica e criativa. A análise de Konder, baseada no materialismo dialético, explica que "pela práxis o homem transformava a ordem das coisas e ao mesmo tempo se transformava" (KONDER, 2009, p. 71).

\footnotetext{
${ }^{10}$ Segundo o Konder, particularmente no período stalinista na União Soviética, "A dialética era negligenciada em favor de uma profissão de fé pretensamente materialista". Ao mesmo tempo, "A subjetividade era concebida em contraposição a essa 'objetividade' (...) e se concentrava no "partidarismo"” (KONDER, 2009, p. 90).
} 
É preciso esclarecer que Konder rejeita a positivação do trabalho e do sujeito, pois esclarece que as classes sociais no capitalismo seriam transitórias, já que constituem um determinado modo de produção. Este entendimento parte do materialismo dialético proposto por Marx, que se opõe à ideia de "continuidade evolutiva" e à noção de "causalidade rígida", automática da história, própria do pensamento positivista. $\mathrm{O}$ autor rejeita ainda a visão do sujeito como portador de uma suposta "natureza ética" com "anseios apaixonados de justiça", que caracterizam a visão idealista nos meios marxistas (KONDER, 2009, p.54-55).

A análise de Leandro Konder é inspirada em Georg Lukács e, particularmente, em sua obra História e Consciência de Classe, escrita em 1922, que teve como objetivo principal propor o aprofundamento da reflexão sobre o papel do sujeito e do método materialista dialético. Lukács esclarece que o conceito de práxis deve ser compreendido como inseparável da teoria do valor criada por Marx. Isto significa dizer que, no modo capitalista de produção, a relação entre sujeito e objeto se dá de maneira simultânea e dialética. A consciência seria formada no contexto de relações sociais próprias de determinados momentos históricos, que definem relações de produção. A partir destas relações, as pessoas se constituiriam simultaneamente como sujeito e objeto. Para Lukács, "Fatalismo e voluntarismo são contraditórios apenas em uma relação não dialética" (2003, p. 68). Ou seja, tanto a noção empirista que vê a sociedade como expectadora do processo histórico, quanto o utopismo que imagina os sujeitos como condutores da história, partem da interpretação comum de separação entre sujeito e objeto.

A obra de Marx inaugura a crítica ao empirismo e ao idealismo. Em Introdução à Crítica da Economia Política, Marx explicita sua visão contrária à ideia da determinação da vontade do sujeito ou de que se pudesse considerar o princípio de uma suposta "natureza humana" do sujeito individualizado. Para ilustrar sua crítica, Marx utiliza como analogia a imagem de "pequenas e grandes robinsonadas", referindo-se à fábula do sujeito idealizado no personagem de Robson Crusoé, que se afirma como personificação da vontade do indivíduo, quando se perde em uma ilha deserta (MARX, 2008, p. 236). Segundo a interpretação de Marx, no modo capitalista de produção só é possível conceber o sujeito como relação social, ou seja, como sujeito-objeto, já que a própria força de trabalho humana é convertida em mercadoria. 
A crítica ao positivismo e ao idealismo servirá de base em nosso estudo sobre a agricultura capitalista que, frequentemente, é associada à noção de desenvolvimento, tanto no contexto brasileiro quanto na conjuntura geopolítica internacional. Ao analisarmos a divisão internacional do trabalho, é possível distinguir os diferentes papéis das economias nacionais no capitalismo. Também é preciso lembrar que o capital já nasce mundializado. Sob essa perspectiva, não faz sentido falar em países desenvolvidos e atrasados. A visão desenvolvimentista gera a impressão de que não há contradições nos países centrais e que a função dos países periféricos seria simplesmente desenvolver suas forças produtivas até alcançarem um suposto patamar ideal. A visão desenvolvimentista ou a análise baseada no tempo como sucessão gera a noção de que seria possível alcançar outro tipo de capitalismo. Em outras palavras, de que haveria um tipo bom e um tipo mau de capitalistas ${ }^{11}$.

A ideia de que seria possível chegar a um modelo padrão de desenvolvimento perde o sentido na medida em que compreendemos que a própria produção e reprodução do capitalismo não ocorreriam sem que os países periféricos propiciassem a acumulação do capital. Nesse sentido, a periferia é tão moderna quanto o centro. Lênin vai mostrar tal processo em sua análise sobre o imperialismo, a partir da lógica da exportação de capitais e da formação de uma economia de monopólio (LÊNIN, 2008, p. 126). ${ }^{12}$ Portanto, quando estudamos o imperialismo, não se trata de imaginar que estamos diante de uma batalha maniqueísta entre vítimas e predadores ou do bem contra o mal, mas de desvendar uma lógica global de expansão-crise do capital, a partir de suas contradições.

É no período marcado pelo caráter monopolista ou imperialista do capital que se observa o processo de industrialização da agricultura, conhecido popularmente como agronegócio. A propriedade monopolista pressupõe a incorporação de todos os

${ }^{11}$ Como explica Alfredo: "Expressões como natureza perversa, globalização perversa, tão somente revelam os limites de uma crítica externa que, assim sendo, se faz como juízo de valor, porque não explicita em sua exposição e negatividade do objeto para com ele mesmo enquanto forma de ser do próprio pensar" (ALFREDO, 2009, p. 386).

${ }^{12}$ Para Lênin, "O que caracterizava o velho capitalismo, no qual dominava plenamente a livre concorrência, era a exportação de mercadorias. O que caracteriza o capitalismo moderno, no qual impera o monopólio, é a exportação de capital" (2008, p. 61). 
momentos da chamada cadeia produtiva, desde o controle sobre matérias primas até a circulação das mercadorias, considerando-se o papel essencial do capital financeiro. A mobilidade do capital faz com que se verifique esse movimento em nível mundial, mesmo com algumas características distintas, que são determinadas por um processo de territorialização a partir da apropriação da renda da terra nos moldes capitalistas. A partir dessa constatação, surge o debate sobre o papel de formas não capitalistas de produção e reprodução no meio rural ou de uma economia camponesa. 


\section{Capítulo 2 - Crise-Acumulação no Modo Capitalista de Produção}

\section{$\underline{\text { A industrializacão da agricultura }}$}

O estágio atual do capitalismo monopolista demonstra a relação de contradição e complementaridade entre o capital agrícola e industrial ou entre setores rurais e urbanos. O processo de expansão do capital no campo favorece setores industriais, caracterizados pelo monopólio de empresas transnacionais, através da implantação de um modelo altamente dependente de insumos químicos e máquinas agrícolas. Este modelo, que passou a ser conhecido como agronegócio, deve ser analisado a partir de uma determinação crítica, própria do desequilíbrio na composição orgânica do capital. A chamada industrialização da agricultura, portanto, se insere no âmbito da relação contraditória entre crise e acumulação do capital.

O Estado, por sua vez, cumpre o papel de mediador de empréstimos bancários para o agronegócio, o que representa transferência de trabalho acumulado ou de maisvalia social, para financiar insumos industriais na agricultura. Os juros, segundo Marx, seriam uma parte da mais-valia apropriada pelo proprietário de dinheiro e controlada pelo setor bancário. Este tipo de recurso, comumente chamado de investimento e interpretado como custo ou risco dos capitalistas, se constitui em transferência de maisvalia social para o setor privado.

Consequentemente, é possível concluir que o produto do agronegócio não seria, por exemplo, soja, gado, cana-de-açúcar, laranja ou eucalipto, mas sim apropriação de capital, seja na forma financeira, através de dívidas, ou da extensão da fronteira agrícola no sentido de apropriar forças produtivas naturais monopolizáveis como terra, água e biodiversidade. Tal constatação não significa que a natureza produz valor. Como vimos no capítulo anterior, de acordo com Marx, a propriedade da terra no modo capitalista de produção representa uma abstração que só se converte em valor a partir da produtividade do trabalho. Samir Amin refere-se a esse tipo de distinção e esclarece que:

Não se trata de saber se a natureza existe ou não; ela existe, bem entendido, intervenham ou não as 'forças da natureza' no processo produtivo, e é lógico que intervêm. A questão é saber quais as condições sociais que regulam o acesso à utilização destas forças (AMIN, 1977, p. 14). 
A análise de tais condições sociais reguladoras passa necessariamente por mecanismos estatais. Ao definir o conceito de complexo agroindustrial, Alberto Passos Guimarães tratou o papel do Estado na integração da agricultura extensiva à indústria e ao capital financeiro, explicando que haveria "um contexto regido segundo a estratégia ditada pelo Estado Industrial, ou, mais precisamente, pelo Capitalismo Monopolista de Estado" (GUIMARÃES, 1978, p. 122).

Entendemos que a criação do conceito de agronegócio, como forma de gerar uma moldura ideológica para a intensificação da industrialização da agricultura, se dá em um contexto determinado pela reprodução crítica do capital. Nesse sentido, é necessário retomar a reflexão sobre a relação simultânea de crise-acumulação no modo capitalista de produção. A economia política tradicional costuma relacionar as situações de crise com elementos conjunturais, como a queda no preço das mercadorias, as flutuações entre oferta e demanda ou o aumento do chamado preço de custo e dos salários dos trabalhadores. Porém, para Marx, a crise no modo de produção capitalista deve ser avaliada a partir das contradições internas do capital em busca constante por valorização. Essa é ao mesmo tempo a essência (ou o segredo) e a aparência (ou a forma de socialização) do capital, que Marx desvendou a partir da análise categorial da forma-mercadoria. O mesmo tema é tratado por Samir Amin, quando afirma que:

A mercadoria é a primeira chave do sistema: é veículo do valor de troca, oculta o valor de uso, é fetiche. (...) A redução da própria força de trabalho a uma mercadoria é a segunda chave do sistema. Esta mercadoria, cujo valor de uso tem a propriedade de criar mais valor do que o que consome, permite descobrir a fonte do excedente (...) apreender sua forma específica (a mais-valia), desmistificar a aparência (a da 'produtividade' do capital), apreender a natureza da ideologia do modo capitalista (o economismo) e suas relações com a infraestrutura (a dominância desta) (AMIN, 1977, p. 16).

Ao descrever a Fórmula Trinitária, que caracteriza a relação capital-terratrabalho no modo capitalista de produção, Marx contesta a percepção fetichista através da qual o produto do capital aparece como lucro, o produto do trabalho aparece como salário e a terra aparece como fonte de renda. O conceito de Fórmula Trinitária esclarece que estes três elementos são provenientes da mais-valia convertida em lucro de capital, salário dos trabalhadores e renda da terra através da forma particular que o trabalho abstrato assume nas relações sociais capitalistas:

(...) o capital não é uma coisa, mas determinada relação de produção, social, pertencente a determinada formação sócio-histórica. (...) Aqui temos, portanto, uma forma social determinada, à primeira vista muito mística, de um dos fatores 
de um processo social de produção historicamente fabricado.(...) Valor é trabalho. Mais-valia não pode ser, por isso, terra. Absoluta fertilidade do solo faz apenas com que certo quantum de trabalho dê certo produto, dependendo da fertilidade natural do solo. (...) E, por fim como terceiro elemento nessa união, um mero fantasma: "o" trabalho, que não é nada mais que uma abstração" (MARX, Livro III, Tomo II, 1985, p. 269-270).

O método utilizado por Marx para compreender o modo capitalista de produção em sua totalidade é essencial para chegarmos ao entendimento do que se constitui como crise. A visão de Marx se diferencia da corrente fisiocrata ou vulgar na economia política exatamente por perceber que as determinações críticas do modo capitalista de produção devem ser desvendadas a partir do fetiche da mercadoria. Referindo-se ao que chamou de "economia vulgar", Marx afirma que:

(...) toda a ciência seria supérflua se a forma de manifestação e a essência das coisas coincidissem imediatamente -, se exatamente aqui a Economia vulgar se sentisse completamente à vontade e essas relações lhe parecessem tanto mais naturais quanto mais a correlação interna está neles escamoteada, sendo, porém, correntes para a concepção comum (MARX, Livro III, Tomo II, 1985, p. 271).

Em O Capital, Marx utiliza constantemente a noção de aparência, no contexto da relação dialética entre essência e aparência ou abstração concreta, para identificar a interpretação fetichista da economia política sobre o capitalismo. Para Marx, a aparência é entendida como abstração que se expressa ou se concretiza nas relações sociais capitalistas; em outras palavras, na luta de classes. Em sua definição de fetichismo, Marx explica que "a forma mercadoria e a relação dos produtos de trabalho, na qual ele se representa, não tem que ver absolutamente nada com sua natureza física e com as relações materiais que daí se originam” (MARX, Vol. I, Tomo I, 1983, p. 71).

Como o movimento principal de desenvolvimento das forças produtivas no capitalismo se dá através da busca pela valorização do valor, a produção de mercadorias seria um mal necessário (GROSSMAN, 1929), pois a determinação principal é a acumulação de capital. Este movimento gera uma contradição do capital para com ele mesmo, pois a busca por valorização ou por aumento na taxa de lucro leva ao desequilíbrio em sua composição orgânica, ou seja, na relação entre trabalho vivo (capital variável) e trabalho morto (capital constante). Segundo Marx, "A verdadeira barreira da produção capitalista é o próprio capital, isto é: que o capital e sua autovalorização apareçam como ponto de partida e ponto de chegada, como motivo e finalidade da produção" (MARX, Vol. IV, Livro III, Tomo I, 1988, p. 180). O produto do capital, portanto, não pode ser entendido a partir de uma medida física ou 
quantitativa, mas deve ser considerado em seu aspecto fantasmagórico, representado na forma-mercadoria.

A partir desta definição, Marx observou que a queda tendencial da taxa de lucro é simultânea ao aumento da massa de capital, que se caracteriza em crise de superacumulação. Portanto, esta "mudança gradual na composição do capital" significa que: "o crescimento paulatino do capital constante precisa, em relação ao capital variável, ter necessariamente por resultado uma queda gradual na taxa de lucro geral, com taxa constante de mais-valia ou grau constante de exploração do trabalho pelo capital (MARX, Livro III, Tomo I, p. 154).

Esta citação esclarece que a chamada crise de superprodução não se dá pelo subconsumo ou por uma deficiência de oferta e demanda. O que ocorre é uma diminuição proporcional entre capital constante e variável. A busca por valorização leva a um aumento na composição orgânica do capital e a um aumento na produtividade do trabalho, o que significa, ao mesmo tempo, impossibilidade de explorar trabalho, impedindo a valorização, já que o trabalho é a única fonte de produção de valor. O processo de desenvolvimento das forças produtivas, particular ao modo capitalista de produção, se expressa através da concorrência entre capitais. Porém, não deve ser confundido com avanço tecnológico, pois a introdução de novas tecnologias para elevar a produtividade do trabalho ocorreu também no período pré-capitalista e não é própria de um determinado momento histórico. O que há de particular no modo capitalista de produção é a relação capital-trabalho. No livro A Questão Agrária e o Capitalismo, Samir Amin esclarece este ponto como parte de sua concepção metodológica:

(...) se o capitalismo é confundido com o uso do chamado 'fator capital' - os instrumentos - terá existido desde sempre, a menos que não o confundamos com a troca mercante, como é tão freqüente. (...) É necessário, para ver claro, aceitar desde o início uma outra visão da ciência social, baseada no conceito de modo de produção (AMIN, 1977, p. 11).

A singularidade da relação capital-trabalho no capitalismo é fundamentalmente o conceito de trabalho como abstração concreta, nos termos de Marx. O desenvolvimento das forças produtivas, que produz não-trabalho ou o chamado exército de reserva, não ocorre pela introdução de novas tecnologias, mas pela incapacidade de o capital explorar trabalho. A contradição, portanto, deve ser entendida a partir da relação entre capital constante e variável e não entre trabalhadores e máquinas (GROSSMAN, 1929). 
Em outras palavras, é preciso interpretar o capital como relação social. Nesse sentido, concluímos que o produto do capital é o valor ou a busca pela valorização do valor e, portanto, os avanços tecnológicos só serão estimulados se significarem maior possibilidade de extração de mais-valia. A concorrência serviria como fator determinante no desenvolvimento das forças produtivas e, simultaneamente (dialeticamente), como elemento de racionalidade ou de coerção, nos termos de Marx, em um movimento predominantemente irracional de crescente formação de monopólios ou concentração de capitais, gerado pela própria concorrência e, ao mesmo tempo, eliminando a concorrência capitalista ${ }^{13}$.

A tendência de valorização "imperfeita" ou "irracional", que constitui o limite do capital para com ele mesmo, pode ser compensada por momentos de crise. Marx explica que, "Se a mais-valia está dada, a taxa de lucro só pode ser aumentada mediante a diminuição do valor do capital constante exigido para a produção de mercadorias". É nesse sentido que entendemos certos mecanismos que podem atuar como "causas contrariantes" ao movimento da queda tendencial da taxa de lucro, que Marx descreve como "economia no emprego do capital constante", através "do aumento da mais-valia absoluta ou do prolongamento do mais-trabalho e, por isso, da jornada de trabalho". Outros mecanismos analisados por Marx incluem o controle da produção ou dos estoques de matérias primas agrícolas e minerais, que entrariam na composição do capital constante (MARX, Livro III, Tomo I, p. 59 a 102).

A partir dos elementos que Marx caracterizou como "causas contrariantes" à queda tendencial da taxa de lucro, Grossman (1929) identifica medidas que podem funcionar como "contra-tendências" em momentos de manifestação da crise no capitalismo. Estas contra-tendências compreenderiam, por exemplo, o aumento da extração de mais-valia ou da produtividade do trabalho e, consequentemente, do tempo de circulação; a desvalorização ou destruição de capital; a exportação de capitais para setores menos produtivos e a apropriação capitalista de matérias primas e de meios de subsistência. Estes fatores funcionariam temporariamente para retardar o movimento crítico do capital, porém não modificariam sua determinação interna, já que é possível

${ }^{13}$ Sobre este ponto, Marx entende que "Nenhum capitalista emprega um novo método de produção, por mais produtivo que seja ou por mais que aumente a taxa de mais-valia, por livre e espontânea vontade, tão logo ele reduza a taxa de lucro. (...) Mas a concorrência generaliza-o e submete-o à lei geral. Então se inicia o descenso na taxa de lucro (MARX, Vol. IV, Livro III, Tomo I, 1988, p. 189). 
verificar um aumento na taxa de mais-valia e, ao mesmo tempo, uma diminuição na taxa de lucro. Para Marx, "mais-valia e a taxa de mais-valia são, em termos relativos, o invisível e o essencial a ser pesquisado, enquanto a taxa de lucro e, portanto, a forma da mais-valia como lucro se mostram na superfície dos fenômenos" (MARX, Vol. IV, Livro III, Tomo I, 1988, p. 32).

É importante notar que Marx considera as chamadas "causas contrariantes" à queda tendencial da taxa de lucro no âmbito da totalidade do modo capitalista de produção e não como fatores externos ao capitalismo. Estes fatores se relacionam com a análise categorial do capital e, portanto, devem ser compreendidos no contexto da sua reprodução crítica, como limite interno. Para Marx, "Dentro de uma situação social dominada pela produção capitalista, também o produtor não capitalista está dominado pelas concepções capitalistas (MARX, Vol. IV, Livro III, Tomo I, 1988, p. 29).

Kostas Vergopoulos segue esse pressuposto para explicar que a diferenciação na composição orgânica do capital permite "fluxos e transferências" de mais-valia social, o que, segundo o autor, "não se apresenta como restrição externa e absoluta, mas como um limite interno constantemente deslocado pelo movimento do capital" (VERGOPOULOS, 1977, p. 80). O papel do comércio exterior no capitalismo, ou a incorporação de setores produtivos com uma composição orgânica menos elevada, é determinado, portanto, pela uma busca por valorização do valor. Em relação a este ponto, destacamos que a análise de Marx entende a unidade produção-circulação como momentos simultâneos do modo capitalista de produção:

(...) tempo de circulação e tempo de trabalho se entrecruzam em seu curso e, assim, ambos parecem determinar por igual a mais-valia; a forma original, em que capital e trabalho assalariado se defrontam, é disfarçada pela intromissão de relações aparentemente independentes dela; a própria mais-valia não aparece como produto da apropriação de tempo de trabalho, mas como excedente do preço de venda das mercadorias sobre seu preço de custo e por isso este último facilmente se apresenta como seu verdadeiro valor (MARX, Vol. IV, Livro III, Tomo I, 1988, p. 33).

Esta citação demonstra que Marx rejeita a ideia tradicional na economia política de que a mais-valia se originaria da venda das mercadorias acima de seu preço de custo, ou seja, de que o valor provém da circulação e não do processo produtivo. Para Marx, o segredo da forma-valor, que elucida o que constitui o "custo" de produção, está na "parte de valor da mercadoria que consiste em mais-valia e não custa nada ao 
capitalista, exatamente porque custa trabalho não pago ao trabalhador (MARX, Vol. IV, Livro III, Tomo I, 1988, p. 22). Tal análise nos ajuda a entender o movimento simultâneo de crise-acumulação do capital e sua determinação crítica, mesmo em momentos conjunturais de mistificação do processo de valorização, quando há aumento da força de trabalho empregada, da expansão comercial ou de maiores investimentos na forma de capital constante, o que representaria a visão fetichista de trabalho acumulado.

\section{O Imperialismo como mecanismo de acumulação capitalista}

A obra de Marx nos proporciona a base teórica para compreender o que outros autores, como Lênin e Rosa Luxemburg, vieram a descrever em seus estudos sobre o imperialismo. Ao retomar o tema da acumulação do capital, em contraposição à predominância do pensamento determinista no marxismo, a obra de Luxemburg vê o imperialismo como elemento essencial para a reprodução capitalista, que deve ser compreendida em seu movimento global ou como um "método específico de acumulação" (LUXEMBURG, 1985, p 336).

Para a autora, o imperialismo não seria uma fase do capitalismo, mas uma condição atemporal do mecanismo de acumulação. O militarismo, nesse sentido, exerceria um duplo papel. Primeiro, de possibilitar o aumento da produtividade do trabalho nos países imperialistas e da transferência desta mais-valia social para o Estado sob a justificativa de financiar a guerra. E, simultaneamente, a guerra teria como função a destruição de capital e representaria uma contratendência em um processo crítico de reprodução capitalista em busca de valorização. Entretanto, o militarismo é geralmente interpretado através da busca de ampliação do comércio externo ou da apropriação de mais-valia e matérias primas em países periféricos, o que realmente ocorre, mas estes fatores representam apenas a superfície da condição de crise do capital.

Rosa Luxemburg reconhece o aspecto crítico da reprodução capitalista, que constituiria o seu limite, na realização da mais-valia a partir de elementos exteriores, mas não externos ao modo capitalista de produção. Sua conclusão se assemelha à abstração feita por Marx para mostrar que a determinação crítica da acumulação constitui a própria lógica capitalista. "A análise de Marx não visa nenhuma 'sociedade capitalista isolada' e coexistente ao lado de outra não-capitalista, preexistente e totalmente diferente; e é igualmente certo que nem mesmo cheguei a mencionar 
nenhuma sociedade desse tipo onde quer que seja", diz a autora (LUXEMBURG, 1985, p. 394). Ao retomar o debate sobre a acumulação do capital, Luxemburg explica tal limite a partir do seguinte processo:

\begin{abstract}
Dessa maneira o capitalismo expande-se graças a suas relações recíprocas com os círculos sociais e com as nações não capitalistas, acumulando seu capital à custa destes; ao mesmo tempo que corrói a cada instante a outra entidade à qual se associa, procurará desalojá-la e assumir seu lugar. E à medida que vai crescendo o número de participantes dessa caçada em busca de novos campos de acumulação do capital (...) acabam constituindo verdadeiras cadeias de catástrofes (de ordem econômica ou política), representadas pelas crises mundiais, pelas guerras e pelas revoluções (LUXEMBURG, 1985, p. 335).
\end{abstract}

A obra de Luxemburg contesta a visão etapista, expressada por Karl Kautsky, ${ }^{14}$ que entende o imperialismo como indutor da industrialização em nível mundial, o que seria uma fase necessária de progresso e de busca por equilíbrio do capital para a chegada ao socialismo. Essa corrente de pensamento assumiu uma posição nacionalista no início do Século XX, um período marcado pela predominância do imperialismo nos moldes burgueses da nação-Estado. A divergência de Luxemburg com o pensamento positivista é explicitada em sua crítica à ideia de um "progresso técnico interminável" (LUXEMBURG, 1985, p. 364).

Referindo-se à sua discordância com Otto Bauer, Luxemburg afirma que, "Se admitirmos ainda, conforme Marx, que em decorrência do progresso técnico existe uma diminuição relativa e constante do capital variável em relação ao número de operários, sua teoria [de Otto Bauer] do 'equilíbrio' cai por terra" (LUXEMBURG, 1985, p. 392).

A noção linear e progressiva de desenvolvimento permanece na atualidade e é comumente utilizada para definir a situação econômica dos chamados países em desenvolvimento. Esta definição gera a impressão de que estes países estariam a caminho de um patamar ideal nos moldes capitalistas; seria somente uma questão de tempo. Tal visão ignora a determinação crítica da acumulação de capital. Sobre este ponto, Samir Amin defende a necessidade de se explicitar uma "crítica sistemática da

${ }^{14}$ De acordo com Löwy, "Como os positivistas, Kautsky tendia a assimilar natureza e sociedade, pretendendo que as leis da sociedade podiam ser definidas como leis naturais" (LÖWY, 2009, p. 135). O mesmo tipo de crítica é feito por Amin, referindo-se à posição de Kautsky sobre a agricultura: "A social-democracia formula a lei deste desenvolvimento em termos simples: a concorrência deve eliminar progressivamente os camponeses, em favor dos grandes capitalistas agrários que dispunham de capitais necessários à utilização da mecanização" (AMIN, 1977, p. 25). 
abordagem convencional de 'subdesenvolvimento', (...) e de uma crítica da visão linear do desenvolvimento, característico da filosofia mecanista da ideologia economista dominante" (AMIN, 1977, p. 33). Em uma perspectiva semelhante, o significado de desenvolvimento é descrito por Mônica Martins como:

Entendo que o subdesenvolvimento e o desenvolvimento não são estágios de crescimento; decorrem da difusão mundial do capitalismo e de sua lógica imperialista. Portanto, os referidos fenômenos pouco dependem de alocações de recursos, mas do modo como o capital deles se apropria, especializando os espaços nacionais e regionais para atender a seus interesses de acumulação (MARTINS, 2008, p. 23-24).

O movimento contraditório de crise-acumulação do capital foi identificado por Lênin em sua obra Imperialismo Fase Superior do Capitalismo, que relaciona o imperialismo com a análise do processo de exportação de capitais e não de mercadorias. Nesse sentido, a exportação de capitais expressaria a crise de valorização nos países centrais do capitalismo e sua busca por maiores taxas de lucro através da apropriação de mais-valia e da renda da terra em países onde os custos da força de trabalho e das matérias primas seriam menores. Lênin explica que este movimento é acompanhado pela concentração do capital bancário, ou seja, do capital financeiro, que passa a ser determinante no processo produtivo. Neste contexto, o Estado assume também o papel central de concessão de crédito para grandes empresas, o que estimula a formação de monopólios privados em setores econômicos estratégicos. Lênin observou a formação de uma oligarquia financeira que consolidou a monopolização de diferentes setores econômicos através da formação de trusts ou cartéis, eliminando a possibilidade de livre concorrência capitalista.

Samir Amin ressalta que a chamada industrialização da agricultura, ou a formação do agronegócio, tem inicio justamente no período do capitalismo identificado como imperialista, que é definido "a partir do momento em que o sistema mundial está constituído sob o bastão do capital monopolista" (AMIN, 1977, p. 25). De acordo com Mészáros (2004), naquele momento histórico que marcou o final da Segunda Guerra Mundial, o imperialismo moderno torna-se "um sistema de dependência estrutural neocolonial e neo-imperialista" (p. 29). Tal análise nos permite retomar a crítica à noção de desenvolvimento como um caminho linear no qual diferentes países se movem, apenas em posições diferentes, como se estivessem numa pista de corrida. 
Quando consideramos as contradições próprias do modo capitalista de produção, entendemos que a formação de monopólios evidencia que o produto do capital é a busca por valorização. Desta forma, a produção de mercadorias torna-se um mal necessário (GROSSMAN, 1929). Como a lógica do sistema capitalista é a produção de valor, o capital financeiro só irá migrar para setores produtivos mediante possibilidade de renda ou lucro suplementar. Mesmo a disponibilidade de crédito a partir da emissão de dinheiro e da geração de déficit orçamentário por parte do Estado não garante que estes recursos se transformem em capital produtivo. A concentração do capital financeiro gera um movimento especulativo em momentos de crise, através da apropriação de valor dos setores menos produtivos e da renda da terra por setores com produtividade mais elevada. É neste sentido que Lênin explica a relação entre o capital financeiro e a especulação com o mercado de terras:

O monopólio dos bancos funde-se neste caso com o monopólio da renda da terra. (...) O monopólio, uma vez que foi constituído e controla milhões e milhões, penetra de maneira absolutamente inevitável em todos os aspectos da vida social, independentemente do regime político e de qualquer outra particularidade (LÊNIN, 2008, p. 56-57).

Lênin retoma a concepção de Marx na qual o próprio espaço do capital é entendido em sua totalidade, como uma abstração, enquanto o tempo é expresso em simultaneidade. Portanto, não faz sentido imaginarmos que no modo capitalista de produção haveria diferença entre progresso e atraso ou desenvolvimento e subdesenvolvimento. As articulações formadas pelo capital financeiro transformam as fronteiras nacionais em abstração. Os chamados mercados futuros, que passaram a caracterizar as exportações de commodities, expressam a busca por valorização em um tempo de rotação que se expressa como simultaneamente.

Ao analisar a recessão mundial do início dos anos 1970, Ernest Mandel constata que a crise se dá após uma "onda longa expansiva" do capital, que tem início no período pós-guerra da década de 1940. Este período é marcado pela expansão de monopólios e maior concentração de capitais. Mandel explica que "A função objetiva da crise é justamente a de fazer com que caiam 'os ramos mortos', isto é, as empresas menos rentáveis" (MANDEL, 1990, p.65).

A formação de monopólios assegura poder suficiente para que grandes empresas possam demandar acesso a créditos bancários e subsídios estatais, o que expressa uma 
crise de sobreacumulação através do aumento da composição orgânica do capital e da impossibilidade de valorização do valor. Mandel chama este processo de "crise de supercapitalização" e explica que "a massa total de mais-valia disponível não permite mais assegurar a todos os capitais a taxa de lucro esperada" (MANDEL, 1990, p. 33). A partir desta situação de crise, acentua-se o processo de descolamento do capital-dinheiro em relação ao processo produtivo, estimulando maior exportação de capitais para a periferia do sistema, em busca de valorização. É neste contexto que se inserem, por exemplo, a crise das dívidas dos países periféricos na década de 1980 e a industrialização da agricultura, que veio a formar o chamado agronegócio no Brasil.

Chesnais (2005) analisa o papel do capital financeiro na atualidade a partir de políticas de desregulamentação do sistema de crédito iniciadas na década de 1950. A hegemonia econômica dos Estados Unidos e o projeto de "reconstrução" na Europa durante o período pós-guerra gerou acumulação de capital proveniente de salários e aposentadorias no sistema bancário. Além da concentração bancária, outras instituições passaram a comandar operações com o chamado "capital portador de juros", entre estas, fundos de pensão e empresas de seguros. Este movimento representou uma enorme transferência de mais-valia social para o setor privado. Chesnais observa que, "O afluxo de recursos não investidos se acelera no início dos anos 70, à medida que o dinamismo da 'idade do ouro' se esgota. Os governos foram obrigados a prolongar sua duração por meio de elevada criação de crédito" (CHESNAIS, 2005, p. 38). Entretanto, a forma encontrada para garantir a continuidade dos sistemas de crédito foi criar mecanismos para que as dívidas públicas dos Estados nacionais pudessem ser negociadas através de títulos no mercado financeiro.

Para Chesnais, a raiz deste processo está na forma particular ou na aparência que a propriedade adquire no modo capitalista de produção, caracterizada como "propriedade patrimonial", ou seja, através da figura do "proprietário-acionista" ou "rentista" (CHESNAIS, 2005, p. 48). Porém, a própria condição de especulação do mercado financeiro significa que, a propriedade privada, seja de títulos bancários ou de terra, não impede a tendência do movimento de crise-acumulação do capital e de perda de sua base de lucratividade, que só poderia se realizar no processo produtivo e, portanto, "relaciona-se ao caráter fetiche, perfeitamente mistificador, dos 'valores' criados pelos mercados financeiros" (CHESNAIS, 2005, p. 45). O autor utiliza outra concepção de Marx quando observa que a expectativa de rentabilidade dos mercados 
financeiros é derivada do caráter "fantasmagórico" que o dinheiro assume no capitalismo (CHESNAIS, 2005, p. 63).

Marx explica o papel dos juros no modo capitalista de produção como o momento em que:

(...) a relação-capital atinge sua forma mais alienada e mais fetichista. Temos aí D - D', dinheiro que gera mais dinheiro, valor que valoriza a si mesmo, sem o processo que medeia os dois extremos (...). O capital aparece como fonte misteriosa, autocriadora do juro, de seu próprio incremento (MARX, Livro III, Tomo I, 1985, p. 278).

Para Marx, este é o sentido do capital fictício, que aparece como criador de mais-dinheiro sem a passagem pelo processo produtivo, que seria a única maneira de encontrar a base material de valorização do valor através da exploração da mais-valia. É esta aparência de autovalorização do dinheiro que lhe dá um caráter puramente fetichista, comparada de maneira irônica por Marx com a capacidade "de uma pereira" que é "de dar peras" (MARX, Livro III, Tomo I, 1985, p. 279). Ou seja, o fetiche seria a naturalização da ilusão de autovalorização do dinheiro.

A partir da crise de superacumulação que marcou a década de 1970, novos mecanismos de desregulamentação do sistema financeiro internacional propiciaram o aumento do fluxo de capital fictício para países periféricos, o que veio a constituir, na década de 1980, a chamada crise da dívida do Terceiro Mundo. Neste período, se iniciam as políticas neoliberais, como forma de garantir novos fluxos de mais-valia social para empresas transnacionais, especialmente em setores de bens essenciais de consumo com potencial de gerar garantias de lucratividade, entre estes, energia, agricultura, mineração, telecomunicações, água, saneamento, saúde, educação. A privatização de fundos de previdência e aposentadoria aprofundou a acumulação financeira, combinada com os pagamentos de serviços da dívida externa a juros flutuantes (CHESNAIS, 2005).

Durante o mesmo período, a exportação de capitais para países periféricos ocorre como forma de aumentar a extração de mais-valia através da busca por força de trabalho mais barata e por apropriação de matérias primas. Esta estratégia foi facilitada pela formulação de políticas neoliberais de abertura comercial com o objetivo de facilitar o fluxo mundial de commodities. Este movimento global faz parte da lógica de acumulação do capital em sua fase monopolista, que se manifesta em forma de crise 
através do processo contraditório que combina "quedas nas taxas de lucro em fases de rápida acumulação" (CHESNAIS, 2005, p. 60).

\section{Capital financeiro e monopólios agroindustriais}

Oliveira (1998) explica que foi principalmente após a Segunda Guerra Mundial que se consolidou a concentração de monopólios privados na forma de empresas transnacionais, a partir da adoção do dólar como moeda internacional, o que gerou uma “disponibilidade financeira em todo o mundo capitalista" (OLIVEIRA, 1998, p. 202). O autor observa que no Brasil este período foi marcado pelo chamado "milagre econômico", quando se intensifica a industrialização da agricultura, principalmente com a entrada em maior escala de capitais internacionais e com o aumento das importações industriais.

No início dos anos 1970, este processo de aparente expansão resultou na crise econômica mundial. Os principais efeitos nos países periféricos foram oscilações cambiais e aumento das taxas de juros, que geraram a crise da dívida ou a chamada "década perdida" nos anos 1980. Segundo Oliveira, "Em 1986 o serviço da dívida chegou a corresponder a cerca de $96 \%$ das receitas brasileiras de exportações" (OLIVEIRA, 1998, p. 302-303). Naquele período, a prioridade do apoio estatal à agricultura extensiva e mecanizada é justificada pelo governo como necessária para saldar a dívida externa e equilibrar a balança comercial. Entretanto, verificamos que a própria dependência de insumos industriais na agricultura contribuiu para gerar números negativos na balança comercial. Oliveira esclarece, portanto, que o endividamento no Brasil "decorre da inserção do país no capitalismo monopolista mundial” (OLIVEIRA, 1998, p.307).

Delgado (1985) estudou o papel preponderante que o capital financeiro assume na agricultura brasileira, principalmente a partir dos anos 1960, como consequência de transformações econômicas estruturais. Entre tais fatores, o autor cita a substituição da base técnica agrícola por insumos industriais, que demandaram uma política particular de crédito governamental e de comércio exterior, e que incluiu incentivos fiscais e novos financiamentos para infraestrutura. A criação do Sistema Nacional de Crédito Rural (SNCR), que oferecia financiamento subsidiado através de bancos estatais, foi essencial para alavancar a industrialização do setor. 
Entre 1969 e 1976, o aumento médio anual do crédito rural no Brasil foi de 23,8\% (DELGADO, 1985, p. 46). Este ritmo de expansão do mercado de dinheiro para a agricultura está relacionado com elementos de instabilidade e crise econômica, que se revelam ao final da década de 1970. Como consequência, os anos 1980 foram marcados pelo estímulo à aplicação de políticas de ajuste estrutural de acordo com o receituário do Fundo Monetário Internacional (FMI). Delgado explica que a "articulação financeira e estatal" resultou em uma "crise do crédito e suas repercussões instabilizadoras sobre a produção agrícola" (DELGADO, 1985, p. 12).

Em relação ao crédito para comercialização, que incluía a garantia de preços mínimos, o autor observa que a prioridade era o apoio aos setores industrializados, como mostram os seguintes dados: $\mathrm{Na}$ safra de 1977-78 os produtores individuais receberam $13,3 \%$, as cooperativas $21,9 \%$ e a agroindústria e comércio 64,8\%; em 197879 os produtores individuais receberam $4,8 \%$, as cooperativas $22,5 \%$ e a agroindústria e comércio 72,7\%; e em 1979-80 os produtores individuais receberam 7,8\%, as cooperativas $23 \%$ e a agroindústria e comércio 69,2\% (DELGADO, 1985, p. 87). O autor explica que o papel do Estado era essencialmente regular "as margens de lucro para os diversos grupos componentes do Complexo Agroindustrial" (DELGADO, 1985, p. 48).

Ao abordar o papel do capital financeiro na agricultura capitalista, Delgado observa que sua determinação se constitui no movimento dinheiro - mercadoria dinheiro. Já na economia camponesa ou mercantil, a lógica é constituída por mercadoria - dinheiro - mercadoria. Por essa razão, na agricultura capitalista "o papel dos bancos passa a ser crucial, uma vez que detendo virtualmente o monopólio de uma mercadoria bastante especial, o dinheiro, por eles passarão necessariamente as demandas crescentes de crédito de curto e de longo prazo" (DELGADO, 1985, pp. 118119). Em um contexto no qual o capital financeiro determina o processo produtivo, é importante notar que a adoção de um sistema de juros flutuantes se constituiu como fator adicional que aprofundou a especulação financeira e a formação de monopólios agroindustriais, que tinham acesso privilegiado a juros subsidiados pelo Estado.

Como já mencionamos anteriormente, a função do capital financeiro é entendida como forma de compensar o limite de valorização gerado pelo desequilíbrio na composição orgânica do capital, que imobiliza uma fração maior de capital fixo e gera 
centralização de capitais e formação de monopólios empresariais. Delgado esclarece que, "neste contexto, a instância financeira assume cada vez maior dominância, como meio de alavancagem de recursos" (DELGADO, 1985, p. 133). Na agricultura capitalista, além de uma maior imobilidade de capital constante gerada pela dependência de insumos industriais, a terra como base produtiva também se constitui em um limite para a circulação de capitais.

O mercado de terras, caracterizado por operações financeiras com base em títulos de propriedade, assume então a função de "descongelar e financiar aplicações fixas de capital" (...) como "faces conexas mas distintas da operação autônoma do capital financeiro" (DELGADO, 1985, p. 194). O autor esclarece que o significado particular da propriedade da terra nos moldes capitalistas é explicado por ser "um bem natural não reproduzível", que se constitui em "títulos patrimoniais monopolizáveis (ações, obrigações e títulos da dívida pública) e, ainda, o dinheiro". E completa, "É da lógica financeira homogeneizar os diferentes rendimentos de diferentes títulos" (DELGADO, 1985, p.195-196). Esta afirmação esclarece a relação entre o mercado de terras e o mercado financeiro, que se entrelaçam no movimento de crise-acumulação de capital. A alternância entre momentos de circulação (expresso no mercado de dinheiro) e de imobilidade do capital (que se expressa em "ativos" financeiros das empresas, como terra e capital fixo) tem como objetivo apresentar tais ativos como "garantias" justamente para acessar crédito.

De acordo com Delgado (1985), a elevação do preço da terra tem a função de possibilitar o aumento da circulação de capital em sua forma financeira ou fictícia. No contexto brasileiro, a expansão do mercado de terras combinou a atuação de grandes empresas bancárias, seguradoras, imobiliárias e industriais. O Estado cumpriu um papel central neste processo, através da concessão de terras públicas para o setor privado, além de crédito e incentivos fiscais para grandes empresas (DELGADO, 1985, p. 203211).

$\mathrm{Na}$ atualidade, observamos a continuidade do papel do Estado como principal agente facilitador de financiamento para o agronegócio, que se combina com as determinações do capital financeiro. Para o autor, a expansão mais recente do agronegócio, principalmente no início dos anos 2000, foi propiciada por uma política que inclui a retomada da prioridade: 
(...) do sistema de crédito público, do mercado de terras e das cadeias agroindustriais, articuladas, pela política econômica de Estado como espaço de acumulação de capital. Essa articulação com caráter estatal-privada, originalmente configurada no regime militar, irá mais adiante ser reproduzida em outro contexto histórico (anos 2000) (DELGADO, 2012, p. 2).

È neste sentido que nossa pesquisa busca resgatar alguns fatores históricos que nos permitem esclarecer a lógica que marca o processo de crise-acumulação da agricultura capitalista, a partir das formas categoriais próprias deste modo de produção. Tal análise nos leva a investigar as determinações que resultaram na construção do conceito de agronegócio. 


\section{Capítulo 3 - $\underline{\text { O Conceito de Agribusiness }}$}

\section{A influência de John Davis e Ray Goldberg como ideólogos do agribusiness}

A palavra de agronegócio foi adaptada no Brasil a partir do conceito de agribusiness, que teve sua origem na School of Business Administration da Universidade de Harvard, com o estudo A Concept of agribusiness de John Davis e Ray Goldberg, publicado em 1957. Segundo Rawlins, “O termo agronegócio foi utilizado primeiramente por John H. Davis, da Harvard University, em 1955. Foi utilizado poucas vezes até 1960, mas durante aquela década ganhou ampla aceitação em nosso vocabulário de leitura e fala" (RAWLINS, 1980, p. 20) ${ }^{15}$.

O livro traz como premissa central a ideia de que o campo estaria passando por grandes transformações a partir de uma "revolução tecnológica", tendo como base o "progresso" científico utilizado na agricultura. Sob essa perspectiva, seria necessário formular políticas públicas de apoio à grande exploração agrícola diante do aumento dos custos de produção, transporte, processamento e distribuição de alimentos e fibras.

Os autores argumentam que o conceito de agricultura como parte integrante da indústria já teria existido há 150 anos quando, além de alimentos, os camponeses produziam seus próprios equipamentos, insumos, combustível, moradia, roupas e utensílios domésticos. A principal mudança observada nas "fazendas modernas" é que deixaram de ser autossustentáveis e passaram a ter função comercial, com sua produção baseada em monocultivos. Atividades como armazenamento, processamento e distribuição dos produtos foram transferidas para outras empresas, que também passaram a produzir produtos industriais utilizados neste modelo agrícola, como tratores, caminhões, combustível, fertilizantes, ração, pesticidas, entre outros. Consequentemente, haveria uma interdependência entre estes setores, mas segundo Davis e Goldberg, até então não existia uma palavra para descrever este processo de fusão entre agricultura e indústria. Daí a proposta de se utilizar o termo agribusiness, pois, segundo os autores, "nosso vocabulário não acompanhou o ritmo do progresso". Este "progresso", descrito no livro, significaria que "nossas fazendas não poderiam

15 Original em inglês:"The term agribusiness was first used by John H. Davis of Harvard University in 1955. It was used very little until late 1960's, but, during the last decade, it has gained wide acceptance in our reading and speaking vocabularies". 
operar nem por uma semana se estes serviços fossem cortados" (DAVIS \& GOLDBERG, 1957, p. 2).

A palavra agribusiness teria sido utilizada pela primeira vez em 1955, durante uma palestra de John H. Davis na conferência do Retail Trade Board em Boston. Na introdução do livro, a definição do termo é descrita como "o total das operações que envolvem manufatura e distribuição de suprimentos agrícolas; operações produtivas nas fazendas; e armazenamento, processamento, e distribuição de commodities agrícolas e produtos feitos a partir destas" (DAVIS; GOLDBERG, 1957, p. 2).

O objetivo do estudo, segundo os autores, seria "entender as relações existentes, particularmente entre funções dentro e fora da fazenda", a partir da hipótese de que "os problemas enfrentados por setores econômicos de alimentos e fibras seriam de natureza e abrangência do agribusiness e não da agricultura" (DAVIS; GOLDBERG, 1957, p. 2). A partir desta constatação, o texto propõe que a centralidade das políticas públicas seja voltada para este setor agrícola-empresarial ${ }^{16}$.

Davis e Goldberg argumentam que a industrialização da agricultura teria proporcionado uma melhora na "qualidade, variedade e nutrição" da comida para a população urbana, através de técnicas de desidratação, salinização, enlatados, preservação, concentração, congelamento e pré-cozimento de alimentos. Eles associam este suposto "progresso" com a "evolução da cadeia alimentar e dos supermercados como técnicas de propaganda de massa" (DAVIS; GOLDBERG, 1957, p. 5). Tal imagem, difundida na época, buscava aceitação da substituição de alimentos frescos por produtos industrializados.

\footnotetext{
${ }^{16}$ A descrição do livro Concept of agribusiness (1957) explica os objetivos deste estudo: "This study is an extension of the original purpose of the Agriculture and Business Program at the Harvard Business School. The original concept of the program was to analyze the complex interrelationships that exist between the farmer and those that supplied him with inputs and those that processed and marketed items that had their origin on the farm so that the private decision maker could take on more responsibility for the effective performance of U.S. agribusiness and its many segments. A concept of Agribusiness, by John II, Davis and Ray A. Goldberg, published in 1957, described these interrelationships and developed a conceptual scheme for portraying and analyzing alternative private and public policies for the U.S. agribusiness economy. This study moves from the description of the total agribusiness economy to a schematic analysis of the ever-changing structure and performance of a widely divergent group of commodity systems". Informações disponíveis no sítio da Universidade de Harvard: http://hbswk.hbs.edu/item/2348.html. Consulta em 20/07/2009.
} 
O "ímpeto da mecanização agrícola", de acordo com o texto, significava uma dependência crescente de produtos produzidos por segmentos da indústria, com destaque para máquinas, tratores e fertilizantes químicos, para compensar o esgotamento da fertilidade do solo. Este processo demandava grande quantidade de energia e estimulou a expansão da produção de petróleo. Ao mesmo tempo, a indústria genética e farmacêutica desenvolvia sementes transgênicas e métodos de inseminação artificial, o que aprofundava, por um lado a segmentação da produção agropecuária e, por outro, a construção de grandes monopólios industriais que se apropriavam da renda da terra.

Como parte do que formaria o chamado agribusiness, os autores incluem proprietários de terra e indústrias, associações de empresários, instituições de pesquisa, universidades, grupos de lobby, além do governo, que assumiria função de apoiar estudos e políticas de regulamentação e comércio. Segundo os autores, este "complexo, descentralizado, segmentado e diversificado" setor formaria "parte importante da economia-importante em tamanho e no fato de prover itens essenciais como comida e vestimenta" (DAVIS; GOLDBERG, 1957, p. 7).

A partir dessa constatação, os autores avaliam que o agribusiness representaria entre $35 \%$ e $50 \%$ da economia estadunidense. Para chegar a estes números, comparam o total que os consumidores americanos gastaram em 1954, US $\$ 236.5$ bilhões, com o que foi gasto em alimentos, bebidas, tabaco, sapatos, roupas e acessórios, que somaria cerca de US\$93 bilhões de dólares, ou 40\% do total consumido naquele ano (DAVIS; GOLDBERG, 1957, p. 8). O detalhamento deste cálculo mostra os seguintes montantes em bilhões de dólares: alimentos industrializados (26.3), alimentos não processados (10.0), gastos em restaurantes (16.4), produtos têxteis (11.0), produtos de couro (3.0), bebidas alcoólicas (1.5), lã e papel (3.0), tabaco (2.8), vendas no atacado e exportação (15.0), outros (3.0).

O percentual de $35 \%$ a $40 \%$ coincide com as estimativas dos ideólogos do agribusiness brasileiro, que baseiam sua estatística nas chamadas cadeias produtivas ou no modelo de novo mundo rural, incluindo o que é produzido dentro e fora da porteira $^{17}$. Tal relação permite que o cálculo do que representaria o peso da agricultura

\footnotetext{
${ }^{17}$ Esta concepção é apresentada em SILVA, José Graziano, O Novo Rural Brasileiro. Revista Nova Economia, Belo Horizonte, Vol. 7, n. 1, p.43-81, maio 1997.
} 
na economia nacional, ou no Produto Interno Bruto (PIB), inclua desde a produção de insumos químicos e industriais, até empresas de comercialização e varejo. As contas que levam a este percentual não consideram as diversas formas de subsídio público ou qualquer outro passivo econômico, social ou ambiental gerado pelo setor. O cálculo convencional do que seria o Produto Interno Bruto ignora a apropriação da mais-valia social ou da força de trabalho acumulada que é transferida para monopólios privados.

O livro de Davis e Goldberg cita fatores "negativos" em contraste com os "inumeráveis benefícios" deste modo de produção. Os autores expressam preocupação com "desajustes e desequilíbrios" em um "progresso evolutivo" que traria "problemas complexos" na relação entre "fazendas comerciais e famílias camponesas pobres" (DAVIS; GOLDBERG, 1957, p. 6). O estudo analisa as mudanças na estrutura econômica da agropecuária durante o período de 1947 a 1954, revelando contradições inerentes à mudança na composição orgânica do capital.

Em relação à mão de obra empregada no setor, o número de trabalhadores permaneceu estável, em cerca de 24 milhões, porém em relação ao total da força de trabalho empregada, houve uma diminuição de $41 \%$ para 37\% (DAVIS; GOLDBERG, 1957, p. 11). Por outro lado, houve um aumento considerável nos custos de produção, sendo que entre estes, $111 \%$ referem-se à depreciação de máquinas, $70 \%$ ao custo com operação de veículos, 57\% com fertilizantes, 35\% com sementes e 59\% com mão-deobra. O montante de vendas do setor, em termos absolutos, teve um crescimento de $56 \%$, porém a margem de lucro diminuiu em 19\% (DAVIS; GOLDBERG, 1957, p 15).

Os autores citam ainda dados sobre o "retorno realizado por hora de todo o trabalho e gerência das fazendas" (Realized Return per Hour to All Farm Labor and Management), ou seja, a taxa de mais-valia social no setor, que apresentou uma queda de 25.5\% entre 1947 e 1954 (DAVIS; GOLDBERG, 1957, p. 15). Esta diminuição contrasta com o aumento na produtividade do trabalho agrícola, estimada em $4 \%$, e com o volume produzido que obteve um crescimento estimado em $9 \%$ no mesmo período.

A contradição inerente ao desequilíbrio na composição orgânica do capital, como revelam esses dados, é ignorada nas conclusões e no próprio método de estudo de Davis e Goldberg, já que os autores mantêm uma perspectiva que imagina a própria história como um movimento contínuo, evolutivo, como se "modernidade" significasse um crescente desenvolvimento tecnológico capaz de dissipar possíveis problemas neste 
curso progressivo, linear e inevitável. O livro descreve a transformação no campo como "produto de uma complexa e evolutiva força, mais ou menos espontânea, sem um rumo ou direção central". Os autores fazem questão de frisar que "de nenhuma maneira é resultado de um plano preconcebido" (DAVIS; GOLDBERG, 1957, p. 6). A ideia de "revolução tecnológica" é apresentada como fórmula para solucionar "desajustes e desequilíbrios" em um "progresso evolutivo". Esta visão permeia a narrativa dos autores e aparece como solução para as contradições deste modo de produção.

A influência de John Davis e Ray Goldberg ultrapassa o meio acadêmico e se dá principalmente na disseminação do conceito de agronegócio como política governamental nos Estados Unidos e em outros países. Davis foi Vice Ministro da Agricultura durante o governo de Eisenhower e presidiu a Commodity Credit Corporation, além de organizar uma série de delegações para incidir em conferências internacionais sobre o tema. Como professor de Harvard, seu objetivo era "lançar uma grade iniciativa para reestruturar a forma de se pensar a agricultura no país"18.

\section{A Segunda Guerra Mundial e o avanco do agronegócio}

Em seu livro Farmer in a Business Suit, Davis apresenta sua visão das transformações no sistema agrícola de forma romantizada, a partir da história ficcional de um agricultor que se torna empresário. O livro mostra como a conjuntura proporcionada pela Segunda Guerra Mundial ocasionou o que Davis chama de "novos impulsos para a transição da agricultura para o agronegócio" (DAVIS, 1957, p. 159) ${ }^{19}$. Ele explica que, “Assim como as tecnologias eletrônica, aeronáutica e atômica foram impulsionadas em resposta às urgências da guerra, o desenvolvimento do agronegócio foi acelerado para atender os desafios das emergências em tempos de guerra" (DAVIS,

\footnotetext{
${ }^{18}$ Estas informações fazem parte da biografia de Davis em seu livro Farmer in a Business Suit (1957). Original em inglês: "Dr. John H. Davis served as Assistant Secretary of Agriculture in President Eisenhower's first administration and was also president of the powerful Commodity Credit Corporation in Washington. Two years ago he moved to Harvard, where the Graduate School of Business Administration was launching a major effort to reshape American thinking about the nation's agriculture. The core of this effort was the new concept of agribusiness worked out by Dr. Davis. He has served as member or chairman of many United States delegations to international food and agriculture conferences".

${ }^{19}$ Original em inglês: "the wartime conditions provided new propulsion for the transition from agriculture to agribusiness".
} 
1957, p. 160) ${ }^{20}$. Davis utiliza o patriotismo relacionado à guerra para promover os insumos industriais que iriam hegemonizar a agricultura. $\mathrm{O}$ seguinte trecho é emblemático:

Serviços e fábricas de armamentos ajudaram a cultivar um terreno que estava sendo plantado com uma gama de equipamentos melhorados para a agricultura e que em tempo iriam crescer como um 'cultivo do negócio', tão grande como a superfície agrícola da terra. Das pranchetas de desenho e das fábricas saem ondas de máquinas poupadoras de trabalho; dos tubos de ensaio e processadoras chegam mais e melhores fertilizantes, pesticidas, vitaminas concentradas, hormônios, antibióticos, plásticos, vacinas e remédios; da pesquisa genética e da produção em massa surgem variedades incríveis de espécies superiores de produtos que podem ser fabulosamente multiplicados através do desenvolvimento de plantas híbridas, tipos artificiais de gado e seleção de famílias superiores de frango e outros animais. E para melhor servir seu país na difícil tarefa de sobreviver à grande guerra, todos os agricultores foram convocados a prover sua fazenda com alguma ou todas essas coisas que aumentarão a produção agrícola (DAVIS, 1957, p. 156) ${ }^{21}$.

A conjuntura de guerra traz elementos essenciais para o entendimento da chamada industrialização da agricultura e também dos fatores que levaram à crise de superacumulação das décadas posteriores. Estes elementos ilustram nossa análise do processo de crise-acumulação do capital através da observação das relações sociais neste momento histórico. Ao adotar um tom ufanista para descrever aquele período, Davis revela alguns aspectos da estruturação do trabalho, por exemplo:

A agricultura americana foi convocada a aumentar a produção de comida para suprir a enorme concentração militar no exterior. (...) Fábricas de todo o tipo foram convertidas para a produção militar, e milhares foram construídas para atender o aumento da demanda por material de guerra. O clamor por trabalhadores tirou mão de obra das fazendas, donas de casa de suas casas, até idosos e deficientes deixaram sua aposentadoria por empregos nas fábricas militares, ou para substituir ocupações civis deixadas por outros mais

\footnotetext{
${ }^{20}$ Original em inglês: "Just as electronic, aeronautic and atomic technology surged forward in response to the urgencies of war, so also did agribusiness accelerate its development in meeting the challenge of wartime emergencies".

${ }^{21}$ Original em inglês: "armed services and war plants, helped plow a field that was being seeded to an array of improved supplies for farming that in time would grow a 'crop of business' as big as the earthbound part of agriculture itself. Off the drawing boards and out of the factories poured a flood of labor-saving farm machines; out of the test tubes and processing plants came more and better fertilizers, pest controls, vitamin concentrates, hormones, antibiotics, plastics, vaccines and medicines; from genetic research and mass-production breeding establishments came the amazing parentage for superior products that could be multiplied fabulously through such developments as plant hybridizing, artificial breeding of cattle and selection of superior families in poultry and livestock. And the better to serve his country in the grim task of surviving the big war, every farmer was urged to supply his farm with any or all of these things that would increase agricultural production".
} 
capacitados para assumir tarefas mais urgentes. Os impostos aumentaram e foi introduzido o sistema de impostos recolhidos na fonte. O público foi estimulado a comprar títulos para financiar os enormes custos da guerra. Controles de preços e salários foram estabelecidos. (...) Necessidades como comida e combustível eram racionadas. (...) Os Estados Unidos tinham oito milhões de homens nas forças armadas e dois terços estavam no exterior (DAVIS, 1957, p. $158)^{22}$.

Os elementos que marcaram a economia estadunidense no período pós-guerra refletem uma situação típica de crise de superacumulação, inclusive com o incentivo para converter as poupanças dos trabalhadores em capital financeiro, na forma de títulos da dívida do Estado. Na agricultura, o aumento da produtividade de grãos e a crescente demanda por investimentos para cobrir os custos com a mecanização geraram a necessidade da criação de diversas políticas governamentais de subsídios internos e para exportação. Para justificar tais medidas, os ideólogos do agronegócio disseminavam um discurso ufanista, relacionado com a imagem da promoção da 'paz mundial', como na seguinte citação:

O complexo do agronegócio na economia dos Estados Unidos é uma maravilha para o mundo. Provavelmente nenhuma nação, no passado ou no presente, tenha se alimentado tão bem e contribuído imensamente para o suprimento mundial de comida. (...) O complexo do agronegócio nos Estados Unidos é tão eficiente e produtivo que o governo federal teve que instituir vários tipos de controle para evitar a superprodução! (...) O sucesso e poder do agronegócio nos Estados Unidos tem potencial para gerar paz e segurança (ROY, 1967, p. 7) ${ }^{23}$.

Com o objetivo de entender o contexto político e ideológico no qual estavam inseridos os primeiros idealizadores do conceito de agronegócio, investigamos o

\footnotetext{
${ }^{22}$ Original em inglês: "American farming was urged to step up production of food in order to supply enormous quantities for our distant military concentrations. (...) Factories of almost every kind were converted to war production, and new plants by the thousands were constructed to expand our output of war materials. The clamor for workers drew the hired hands off the farms, took the housewives out of homes, even brought the elderly and the handclapped out of retirement for jobs in the war plants or to fill civilian occupations vacated by those capable of handling more urgent assignments. Taxes were increased and the withholding system for collecting income taxes was introduced. The public was urged to buy bonds to finance the staggering cost of the war. Price and wage controls were in effect. Necessities such as food and fuel were rationed. (...) The United States had eight million men in its armed services and two thirds of them were overseas".

${ }^{23}$ Original em inglês: "The agribusiness complex in the U.S. economy is the marvel of the world. Probably no nation, past or present, has been better fed itself and contributed so immensely to world food supplies as well. (...) The U.S. agribusiness complex is so efficient and productive that the federal government has had to institute controls of various kinds to see that overproduction is held back! (...) Such is the success and power of U.S. agribusiness and also its potential for world peace and security".
} 
trabalho de Ray Goldberg. Sua biografia revela a estreita relação com empresas do agronegócio, com instituições de crédito e com órgãos governamentais, como Commodity Futures Trading Commission, Agency for International Development, President's Food and Fiber Commission, the National Marine Fisheries Service, U.S. Comptroller of the Currency e National Academy of Sciences. Goldberg foi assessor de instituições privadas como World Food System Inc., Ford Foundation e Winrock International, além de institutos agrícolas na Nicarágua e no México. No meio acadêmico, fez parte do conselho editorial das publicações Food Policy Journal e American Journal of Agricultural Economics. Como professor de Harvard, coordenava um curso anual para "150 lideranças empresariais de vários países para analisar estudos de caso sobre a produção do agronegócio, marketing e situações financeiras" (CRAMER; JENSEN; SOUTHGATE, 2001, p. 46). ${ }^{24}$

\section{$\underline{\text { A exportação do modelo do agronegócio para a América Latina }}$}

Uma parte das publicações de Goldberg era voltada particularmente para a América Latina, principalmente para os países centro-americanos. Na introdução do livro Agribusiness Management for Developing Countries with Special Reference to the Central American o autor explica que, "O objetivo do estudo é proporcionar um modelo conceitual para a análise do sistema de commodities do agronegócio, que acreditamos ser útil para a educação dos participantes do agronegócio nos países da América Central" (GOLDBERG, 1974, p. 1-3). O livro é centrado na promoção de commodities que têm potencial de "satisfazer as necessidades de consumo nos Estados Unidos" (GOLDBERG, 1974, p. 3).

\footnotetext{
${ }^{24}$ A biografia de Ray A. Goldberg está no livro Agricultural Economics and Agribusiness (2001). Original em inglês: "Dr. Goldberg has served as an officer and director of numerous agribusiness films in the food and financial sectors of agriculture, and has been consultant to a diverse group of public and private agencies including the Commodity Futures Trading Commission, Agency for International Development, President's Food and Fiber Commission, the National Marine Fisheries Service, U.S. Comptroller of the Currency, National Academy of Sciences, World Food System Inc., Ford Foundation, Winrock International, institutes in Nicaragua and Mexico, and many other agriculturally oriented organizations. In addition, he is on the Editorial Board of the Food Policy Journal and similarly served for the American Journal of Agricultural Economics. About 150 Harvard M.B.A.s each year concentrate on an agribusiness major under Professor Goldberg's supervision. He directs the national and international agribusiness Continuing Education programs at the Harvard Business School. These programs bring together about 150 of the world's agribusiness leaders each year from private industry to analyze case studies of agribusiness production, marketing, and financial situations".
} 
Goldberg explica o chamado "sistema do agronegócio" a partir de sua integração com empresas de transporte, armazenamento, comercialização e financiamento, destacando o papel de uma instituição em particular, chamada Latin American Agribusiness Development Corporation (LAAD), que teria a função de coordenar este processo. Na introdução do livro, o autor explica que:

O sistema do agronegócio de commodities existe para atender as necessidades nutricionais do consumidor, seu estilo de vida, e das mudanças de valores na estrutura da sociedade. Inclui todos os participantes na produção, processamento e comercialização de um mesmo produto agrícola, como fornecedores, agricultores, operadores de estoques, processadores, comerciantes de atacado e varejo envolvidos no movimento de uma commodity, desde os insumos iniciais até o consumidor final. Também inclui todas as instituições e arranjos que afetam e coordenam os estágios sucessivos do movimento de uma commodity, como o governo, mercados, mercados de futuro, integração contratual, integração vertical, associações comerciais, cooperativas, fusões de empresas, parcerias financeiras, grupos de transporte e organizações educativas (GOLDBERG, 1974, p. 4$)^{25}$.

Goldberg avalia que a concepção de agronegócio passou a ter ampla aceitação por parte da opinião pública e foi incluída no planejamento estratégico do governo e do setor provado nos Estados Unidos. Em relação à influência dessas ideias no meio acadêmico, Goldberg avalia que "desde o desenvolvimento do conceito na Harvard Business School em 1957, foram estabelecidos programas e cursos em agronegócio em mais de 80 universidades nos Estados Unidos e pelo menos em 10 em outros países" (GOLDBERG, 1974, p. 5$)^{26}$.

\footnotetext{
${ }^{25}$ Original em inglês: "The agribusiness commodity system exists for the purpose of catering to the consumer's nutritional needs, his style of living, and his society's changing value structure. It encompasses all the participants in the production, processing, and marketing of a single farm product, including farm suppliers, farmers, storage operators, processors, wholesalers, and retailers involved in a commodity flow from initial inputs to the final consumer. It also includes all the institutions and arrangements that affect and coordinate the successive stages of a commodity flow, such as the government, markers, future markers, contractual integration, vertical integration, trade associations, cooperatives, corporate joint ventures, financial partners, financial entities, transport groups and educational organizations".

${ }^{26}$ Original em inglês: "The agribusiness commodity systems approach to private and public decision making has gained widespread acceptance in the United States in the strategic planning activities of private and public decision makers and in the development of a variety of agribusiness management courses and programs at a number of educational institutions. From the development of the concept at the Harvard Business School in 1957, agribusiness programs or courses have been established in over 80 universities in the United States and at least 10 in other countries".
} 
Em 1985 foi publicado o primeiro número da revista Agribusiness: An International Journal, voltada para empresários do agronegócio e para difundir sua ideologia no meio acadêmico. O editorial cita o livro de Davis e Goldberg como o primeiro a definir o termo 'agronegócio' e lembra que o primeiro curso especializado sobre o setor foi criado na Universidade de Harvard em 1956. Diz também que em 1985 havia mais de 60 cursos semelhantes em universidades dos Estados Unidos, que passaram a ser disseminados em outros países. Em relação ao contexto internacional, o editor afirma que:

O agronegócio é um setor importante na economia de praticamente todos os países. Com o desenvolvimento dos países, há uma tendência de avanço dos insumos industriais e do processamento de commodities, da industrialização da comida, e de empresas de distribuição que crescem enquanto o setor produtivo diminui em termos do número de pessoas empregadas (WOOLVERTON, 1985, p. $1-3)^{27}$.

O texto relaciona a adoção de "inovações tecnológicas" com a "relativa escassez de mão de obra" e reconhece que os agricultores passaram a "comprar praticamente todos os insumos de outros setores". O autor dá uma conotação positiva e atribui este processo ao "desenvolvimento dos negócios de insumos" (WOOLVERTON, 1985, p. 1$3)$.

A revista traz um artigo de Ray Goldberg intitulado "O Conceito de Sistema Alimentar Global e seu Uso por Gerentes Públicos e Privados ${ }^{28 \%}$. O texto define agronegócio como "o mais importante setor da economia mundial". Goldberg descreve sua visão de "sistema alimentar global" como sendo a relação entre consumidores, empresas de marketing, empresas processadoras, agricultores e empresas de insumos agrícolas. Segundo o autor, este "sistema" necessitaria de instituições "coordenadoras", que seriam órgãos governamentais, mercados de futuro, estruturas para facilitar a fusão entre empresas, acordos internacionais sobre o comércio de commodities, instituições de pesquisa e ensino, instituições financeiras multilaterais (como o Banco Mundial) e empresas multinacionais (GOLDBERG, 1985, p.9-11).

${ }^{27}$ Original em inglês: "Agribusiness is an important sector of nearly every country's economy. As countries develop, the input supply industries and commodity processing, food manufacturing, and distribution firms tend to evolve and grow while the production sector shrinks in terms of number of people employed".

${ }^{28}$ Ray A. Goldberg, A Concept of a Global Food System and Its Use by Private and Public Managers, p 5-23. In Agribusiness: An International Journal, Vol. 1, Number 1, Spring 1985. 
Ross (2000) explica que a base política e ideológica para a expansão do conceito de agronegócio na América Latina ocorre através da criação da Latin American Agribusiness Development Corporation (LAAD) por empresas e pelo governo estadunidense. Esta empresa começa a ser forjada no período da Guerra Fria e coincide com a difusão do programa "Aliança para o Progresso", estabelecido pelo então presidente John F. Kennedy, com o objetivo de frear a influência da revolução cubana na região.

Segundo Ross, a idealização da "Aliança para o Progresso" partiu de Raul Prebisch, que era diretor da Comissão Econômica para a América Latina da ONU (ECLA - UN Economic Commission for Latin America). Ross afirma que:

Os argumentos de Prebisch eram amplamente debatidos em Washington. Em uma jogada de mestre, desenhada para tirar a base do alto prestígio moral do modelo cubano de desenvolvimento, o presidente John F. Kennedy anunciou a Aliança para o Progresso em 1961 (ROSS, 2000, p. 11). ${ }^{29}$

Ross foi presidente da LAAD entre 1972 e 1998, mas sua influência em meios empresariais e governamentais nos países latino-americanos é anterior a este período. Através de sua relação com a ECLA, em 1962 torna-se professor do Instituto de Planejamento Econômico e Social da ONU no Chile e, posteriormente, trabalha no Banco Central do Paraguai. Em 1965, Ross atua no Peru como integrante da empresa Adela Investment Company formada por "um grupo de corporações multinacionais de vários países para promover investimentos de capital na América Latina” (ROSS, 2000, p. xiv).

O surgimento da LAAD em 1972 faz parte desta mesma concepção e tem como objetivo explícito "fortalecer empresas privadas do agronegócio na América Latina" (ROSS, 2000, p.3). Porém, de acordo com o próprio Ross:

Está claro que a principal motivação para o programa massivo de ajuda para a América Latina teve a intenção de conter a propagação da influência comunista e de fortalecer a ampla posição de segurança dos Estados Unidos e seus aliados (ROSS, 2000, p. 12). ${ }^{30}$

\footnotetext{
${ }^{29}$ Original em inglês: "Dr. Prebisch arguments were thoroughly debated in Washington. In a masterful move designed to take the moral high ground away from the Cuban approach to development, President John F. Kennedy announced the Alliance for Progress in 1961”.

${ }^{30}$ Original em inglês: "It is clear that the primary motivation for this massive aid program to Latin America was intended to stem the spread of Communist influence and to strengthen the overall security position of the United States and its allies".
} 
Algumas das principais empresas promotoras e financiadoras da LAAD foram Cargill, Monsanto, Borden Inc., Caterpillar Tractor Company, CPC International, Dow Chemical, Gerber Products, Ralston Purina, Standard Fruit and Steamship Company, Goodyear Tire and Rubber Company, além dos bancos Rabobank Nederland, Chase Manhattan, Bank of America, Girard Bank e Southeast Banking Corporation of Miami. Outras iniciativas formadas no mesmo período foram Private Investment Company for Asia (PICA), com sede em Tóquio, e Sociedade Internacional para o Financiamento de Investimentos na África (SIFIDA), com sede em Genebra (ROSS, 2000, p. 3-4). A sede escolhida para a fundação da Latin American Agribusiness Development Corporation (LAAD) foi o Panamá porque, segundo Ross, "seu governo não cobra impostos de empresas que atuam fora de suas fronteiras" (ROSS, 2000, p. 15).

Na avaliação de Ross, a atuação da LAAD durante três décadas na América Latina foi bem sucedida por se tornar uma "corporação lucrativa especializada em financiar investimentos em projetos do agronegócio", além de "recuperar a agricultura depois de décadas de estagnação e reforma agrária, iniciando parcerias dinâmicas no crescimento econômico da região" (ROSS, 2000, p. 4-5).

O autor critica as políticas de controle de preços dos alimentos por governos considerados "reformistas" e que teriam como função "conter o descontentamento popular em áreas urbanas" (ROSS, 2000, p. 12). Além disso, Ross expressa preocupação com os processos de reforma agrária em curso na região e cita como exemplos os casos do Chile, El Salvador, Peru e Bolívia. Segundo sua perspectiva:

Nesses quatro países, a produção agrícola ficou estagnada já que os agricultores eficientes foram afugentados de suas terras e substituídos por agricultores pobres e ineficientes. Esses novos agricultores foram acostumados a produzir para suas próprias famílias e não para o mercado. Eles não são financiáveis. Eles são analfabetos e incapazes de aprender novas tecnologias (ROSS, 2000, p. 14). ${ }^{31}$

A difusão da ideia de que os processos de reforma agrária e os modos de produção dos camponeses não eram "eficientes" serviu para facilitar os negócios de grandes empresas multinacionais na agricultura. A expansão do agronegócio na América Latina se caracterizou pela concentração de capitais multinacionais,

\footnotetext{
${ }^{31}$ Original em inglês: "In all four countries, agricultural production stagnated as efficient farmers were chased off their land and replaced by poor and inefficient farmers. These new farmers were accustomed to produce for their own families and not for the market place. They are not bankable. They were illiterate and unable to learn new technologies".
} 
principalmente no setor de maquinário, insumos químicos e processamento de alimentos.

A indústria de tratores, por exemplo, era controlada por apenas quatro empresas estadunidenses (John Deere, International Harvester, Ford e J. I. Case) e uma canadesnse (Massey Ferguson). A partir da década de 1960, essas empresas montaram subsidiárias na América Latina, principalmente nos países onde havia maior crescimento do agronegócio, possibilidades de acesso a incentivos governamentais e baixo custo de mão de obra, como Brasil, México e Argentina (BURBACH; FLYNN, 1980, p. 110-111).

Durante o período da ditadura militar no Brasil, Argentina, Chile e Uruguai verificam-se a diminuição média dos salários dos trabalhadores e o aumento do nível de exploração do trabalho. Como os custos dos insumos químicos e industriais eram padronizados em nível internacional, os países latino-americanos buscavam manter níveis aceitáveis de competitividade através da maior exploração dos trabalhadores rurais (BURBACH; FLYNN, 1980, p. 138).

Altieri (2000) explica que o uso intensivo de insumos químicos no sistema agrícola baseado em monocultivos gerou aumento de produtividade em um primeiro momento, mas a tendência é a diminuição ou a manutenção dos níveis de produção em relação à necessidade crescente do uso de pesticidas e fertilizantes. Alguns fatores que causam a queda da produtividade estão associados à perda de nutrientes naturais e à erosão do solo, além da poluição de fontes de água. Outro problema está relacionado com a resistência desenvolvida a certos tipos de agrotóxicos nos monocultivos, o que é agravado pela perda da biodiversidade.

As maiores produtoras de fertilizantes, que controlavam o mercado mundial no período de disseminação do agronegócio na América Latina, eram empresas estadunidenses, principalmente W. R. Grace, Monsanto, International Mineral \& Chemicals, Williams Companies, Beker Industries, Exxon e Allied Chemical. Inicialmente, essas corporações priorizavam a exportação de fertilizantes para países do chamado "Terceiro Mundo" e não a implantação de subsidiárias para a produção local. A exportação de fertilizantes era subsidiada nos Estados Unidos através da Agência para o Desenvolvimento Internacional (Agency for International Development - USAID), sendo que os principais mercados na América Latina eram Chile e Brasil. Em meados dos anos 1970, as multinacionais de fertilizantes passaram a estabelecer unidades em países latino-americanos, aproveitando financiamento de governos locais e de 
instituições como o Banco Interamericano de Desenvolvimento. Outras vantagens eram o acesso a fontes de energia a baixo custo e a falta de regulamentação ambiental (BURBACH; FLYNN, 1980, p. 112-115).

O mercado de pesticidas era controlado principalmente pelas empresas Dow Chemical, Eli Lilly, Dupont, Monsanto e Chevron, que comercializavam agrotóxicos em países do Terceiro Mundo como forma de escoar sua produção, inclusive de muitas substâncias banidas nos Estados Unidos, como o DDT. A proliferação desses produtos foi bastante ampla, inclusive entre pequenos agricultores, já que eram bem mais baratos se comparados aos fertilizantes químicos e ao maquinário, utilizados mais comunmente pela grande exploração agrícola (BURBACH; FLYNN, 1980, p. 117).

Algumas multinacionais do agronegócio que estabeleceram subsidiárias na América Latina concentravam tanto a produção para os mercados nacionais quanto a exportação de seus produtos, como é o caso da United Fruit, Swift and Armour e Cargill. Grandes bancos também participavam do mercado de exportações agrícolas, entre eles Morgan Guaranty Trust e Chase Manhattan. O papel de agentes financeiros e do monopólio na comercialização facilitou o aumento da especulação com produtos agrícolas nos mercados de commodities, incluindo os mercados de futuro (BURBACH; FLYNN, 1980, p. 131-132).

Os autores explicam que a relação entre a formação de monopólios privados de comercialização e a especulação com o preço de commodities agrícolas ocorre quando há "o controle de unidades processadoras e o seu enorme poder financeiro lhes permite fazer grandes compras quando o preço de mercado está baixo, estocar, e então obter lucros extraordinários quando o preço sobe" (BURBACH; FLYNN, 1980, p. 133). Em relação ao papel do Brasil, observam que apesar de o país ser grande exportador de produtos agrícolas, este comércio foi controlado por empresas estrangeiras. O Brasil era:

(...) o segundo maior exportador agrícola (depois dos Estados Unidos), [porém] seus capitalistas nacionais exercem um papel marginal no mercado internacional. Anderson Clayton é a maior exportadora do algodão brasileiro, uma subsidiária da Coca-Cola, Minute Maid, comercializa o suco de laranja brasileiro no exterior, Cargill é líder em exportação da soja e do óleo de soja do Brasil, enquanto a General Foods compra grande parte dos grãos de café do Brasil (BURBACH; FLYNN, 1980, p. 134).

$\mathrm{Na}$ década de 1970, apenas cinco empresas, operadas por oito famílias, controlavam $85 \%$ do mercado internacional de grãos: Cargill, Continental Grain, Bunge, Dreyfus e Andre-Garnac. A história destes grupos revela que o processo de 
maior monopolização de empresas do agronegócio ocorre no período pós-guerra e sua expansão na América Latina é facilitada pelas ditaduras militares a partir da década de 1960. O estudo de Burbach e Flynn mostra que:

Essas empresas mantêm estruturas de negócio integradas que se expandem da produção agrícola até os mercados externos. Nacionalmente, controlam estruturas de carregamento de grãos, containers para estocagem, sistemas de transporte e terminais portuários; operam empresas parceiras que controlam o escoamento para outros países (BURBACH \& FLYNN, 1980, p. 221-223).

Os autores esclarecem que apesar de sua influência em vários setores do agronegócio, a preferência destes grupos seria pelo controle da comercialização e não necessariamente da produção agrícola. Desta forma, estas empresas estariam livres de arcar com prejuízos em casos de situações adversas próprias da agricultura em determinadas safras e regiões. Por exemplo, certas condições climáticas ou instabilidade na conjuntura econômica e política podem interferir nos níveis de produtividade agrícola. Tal argumento justificaria a permanência de pequenos e médios produtores em determinados ramos da agricultura, porém, nestes casos, estariam "integrados" nas chamadas "cadeias produtivas" do agronegócio (BURBACH; FLYNN, 1980, p. 221223).

Apesar de se constatar o aumento do número de grandes propriedades rurais, principalmente em função do processo de "industrialização" da agricultura, verifica-se a manutenção de um setor significativo composto por pequenas e médias fazendas nos Estados Unidos (como veremos em dados apresentados mais adiante neste capítulo). Segundo Burbach e Flynn, é possível explicar a permanência de pequenas e médias unidades agrícolas pelo fato de arcarem com o 'risco' da produção rural, enquanto que para corporações multinacionais seria mais vantajoso concentrar suas atividades nos negócios de insumos, processamento e comercialização (BURBACH; FLYNN, 1980, p. 30-31).

Um dos mecanismos essenciais de controle do mercado internacional, utilizado por grandes empresas de comercialização de commodities, ocorre através de sua atuação nos mercados de futuro. Além das apostas relacionadas aos preços de commodities agrícolas, outras formas de especulação do agronegócio nos mercados de futuro incluem a negociação com contratos de espaços para cargas. Por exemplo, estes espaços podem ser comercializados, porém não utilizados com carregamento de grãos, de acordo com a necessidade de se influenciar seu preço no mercado internacional. Outra estratégia seria modificar o destino dos carregamentos de acordo com as vantagens vislumbradas de 
negócios em determinados países, principalmente quando há escassez de alimentos. Este tipo de transação permite ainda que as empresas de comercialização atuem de forma combinada nos mercados de câmbio, já que operam com moedas de diferentes países (BURBACH; FLYNN, 1980, p 224).

De acordo com a perspectiva das empresas do agronegócio, uma das funções deste modelo agrícola seria ampliar mercados para setores financeiros e industriais, além de possibilitar um excedente de trabalhadores e de alimentos a baixo custo para a indústria. A "exportação" deste modelo aprofunda a especialização dos monocultivos em determinados países e a divisão internacional do trabalho, a partir da herança colonial. Na América Latina, a expansão deste modo de produção na agricultura garante a manutenção do papel exercido historicamente por países da região, como fornecedores de matérias primas a partir da demanda mundial, principalmente de países industrializados.

Burbach e Flynn verificam uma crescente desproporção entre os preços das matérias primas agrícolas exportadas por países latino-americanos e sua relação com os insumos industriais importados. Os autores afirmam que:

Hoje a América Latina precisa vender maiores quantidades de commodities no exterior somente para importar a mesma quantidade de produtos manufaturados. Enquanto se precisava de 160 sacas de café para comprar um trator em 1960, são necessárias 400 sacas para comprar o mesmo trator em 1970 (BURBACH; FLYNN, 1980, p. 134).

$\mathrm{Na}$ América Latina, a concentração fundiária em grandes extensões de terra também é combinada com a exploração do trabalho e do excedente da produção camponesa como, por exemplo, nos sistemas de colonato. Neste caso, os chamados "colonos" são camponeses ou trabalhadores rurais que produzem alimentos em um lote de terra "cedido" pelo proprietário em troca de uma determinada quantidade de trabalho ou produto excedente.

As formas de subordinação do trabalho camponês são variadas e podem ocorrer através de contratos de fornecimento com empresas do agronegócio, que demandam um produto específico. Há também contratos de arrendamento de terras camponesas que passam a ser utilizadas por grandes empresas que praticam o monocultivo extensivo. Estes tipos de contrato normalmente causam endividamento dos pequenos agricultores e podem gerar até mesmo a perda da terra, já que os camponeses assumem os riscos da produção, mas dependem das flutuações dos mercados de commodities. 
Em muitos países da América Latina, a expansão do agronegócio, principalmente a partir da década de 1960, acentua os despejos de comunidades rurais, causando a migração massiva para os centros urbanos, o aumento do proletariado rural e do chamado "exército de reserva", ou seja, um contingente de trabalhadores "dispensáveis" que funciona para manter baixos níveis salariais tanto no campo quanto nas cidades. Apesar dos processos de êxodo rural, verifica-se que a produção camponesa segue como principal responsável pelo fornecimento de alimentos para mercados locais. Ao mesmo tempo, a luta de classes no campo se expressa através da organização de movimentos populares de luta pela terra (BURBACH; FLYNN, 1980, p. 146-149).

\section{$\underline{O}$ período pós-guerra e a crise de superacumulação}

A década de 1970 foi marcada por efeitos da crise econômica mundial, o que gerou instabilidade no mercado de commodities agrícolas. Goldberg (1985) interpreta este período de forma positiva, principalmente porque a crise estimulou os processos de fusões e a formação de novos monopólios entre empresas do agronegócio. Alguns exemplos deste processo foram fusões entre as empresas ADM, Intrade e Toepfer; e entre os grupos Continental Grain e A.E. Staley. Neste mesmo período a Cargill adquiriu outras empresas do ramo. Uma das principais mudanças na estrutura do agronegócio naquele momento se caracterizou pelo aprofundamento dos monopólios privados no setor de comercialização, que até então era majoritariamente controlado por órgãos governamentais (GOLDBERG, 1985, p. 12).

Dados coletados por Ingolf (1981) confirmam a crescente tendência de formação de monopólios entre empresas ligadas ao agronegócio durante os anos 1970. O autor identifica que, em 1979, 60\% da produção de insumos estavam concentradas em 15 empresas; $68 \%$ dos alimentos processados eram produzidos por 49 empresas; e $77 \%$ das vendas em atacado eram controladas por 44 empresas (INGOLF, 1981, p. 106).

A formação de monopólios se concretiza através dos processos chamados de “integração vertical e horizontal”. Este tipo de definição é utilizado por ideólogos do agronegócio para caracterizar fusões completas entre empresas ou as chamadas "parcerias contratuais", que estabelecem acordos comerciais entre setores de uma determinada "cadeia produtiva". Nos anos de 1970, este tipo de negócio ocorreu com 
frequência entre empresas de produção e distribuição e entre empresas de transporte e comercialização. Em relação à produção agrícola, Goldberg avalia que o nível de concentração foi menor, devido à permanência de um número significativo de pequenas e médias propriedades rurais nos Estados Unidos. Mesmo assim, verifica-se o aumento do número de grandes fazendas em decorrência da crescente necessidade de capitalização para cobrir os custos de mecanização das lavouras (GOLDBERG, 1974, p. 25-26).

Em um documento elaborado com o objetivo de assessorar a política agrícola do governo estadunidense para o período entre 1970 e 1980, Goldberg (1968) ${ }^{32}$ reafirma e defende a tendência de aumento na produção de alimentos processados. Segundo tal perspectiva, o processo industrial permitiria a propaganda de determinadas marcas de produtos, que poderiam ser dirigidos para públicos específicos como crianças, jovens e idosos. Seria possível ainda, de acordo com esta estratégia, promover alimentos com características "vendáveis", como aqueles de baixa caloria, percebidos como próprios para dietas.

A expansão da indústria de alimentos processados demandava altos custos com propaganda e marketing. Por sua vez, o alto custo com propaganda determinava que a distribuição desses produtos fosse feita de forma massiva. Desde o período pós-guerra, estima-se que os gastos do agronegócio com publicidade nos Estados Unidos tenham aumentado constantemente. Em 1960 foram gastos \$44.6 bilhões de dólares e em 1977 esta cifra subiu para $\$ 124$ bilhões de dólares, o que equivale a um aumento de $175 \%$ (RAWLINS, 1980, p. 158).

Os promotores do agronegócio reconhecem a relação entre a industrialização de alimentos e o processo de concentração de mercado, como identificamos na citação a seguir:

Serão desenvolvidas outras formas de alimentar as pessoas, não só nos Estados Unidos, mas também nas nações em desenvolvimento. (...) Novas formas de processamento, empacotamento, armazenamento e marketing. (...) Teremos um

32 Technical Paper by the National Advisory Commission on Food and Fiber (BIRD; ARTHUR; GOLDBERG, 1968). 
número menor de estabelecimentos de venda, mas serão maiores. Relações entre conglomerados prevalecerão (BIRD; ARTHUR; GOLDBERG, 1968, p. 2$)^{33}$.

O documento, intitulado Technical Paper by the National Advisory Commission on Food and Fiber (BIRD; ARTHUR; GOLDBERG, 1968), contém uma série de recomendações para o governo, principalmente em relação à política externa. $\mathrm{O}$ texto prevê a continuidade do envolvimento dos Estados Unidos em guerras, o que segundo os autores, aumentaria a demanda mundial e o preço dos alimentos. O documento defende programas de "ajuda alimentar" como forma de escoar o excedente agrícola dos Estados Unidos para outros países e propõe a negociação de garantias contratuais para empresas norte-americanas que atuam no exterior.

Os programas de "ajuda alimentar" promovidos pelo governo estadunidense, tanto nacionalmente quanto em outros países, exerceram um papel fundamental para a expansão agronegócio, como mostra a seguinte citação:

O Governo Federal instituiu programas de ajuda para os membros menos favorecidos da nossa sociedade. Programas elaborados para melhorar a dieta que, em compensação, promovem o aumento do mercado para produtos agrícolas. (...) Ajudar a alimentar as pessoas dos países subdesenvolvidos será importante nos próximos anos (BIRD; ARTHUR; GOLDBERG, 1968, p. 3$)^{34}$.

Segundo o documento, as recomendações de Bird, Arthur e Goldberg (1968) para o governo dos Estados Unidos incluem o aumento dos requisitos para a padronização de alimentos e das restrições de "controle de qualidade", o que serviria para dificultar a diversificação da produção e as importações de outros países.

A tendência de padronização e monopolização das empresas do agronegócio é defendida pelos autores como forma de compensar a suposta necessidade de diminuição da força de trabalho, causada pela pressão dos trabalhadores por aumento de salários e benefícios. O processo crítico de aumento na composição orgânica dos capitais do agronegócio, que na verdade perdem capacidade de explorar trabalho com a crescente

\footnotetext{
${ }^{33}$ Original em inglês: "There will evolve new ways and means of feeding people, not only in the United States, but in developing nations as well. (...) New ways of processing, handling, storing, and marketing them. (...) There will be fewer but larger food marketing establishments. Conglomerate relationships will be much more prevalent."

${ }^{34}$ Original em inglês: "The Federal Government has instituted many programs to aid the less fortunate members of our society. Programs designed for improving their diet will in turn provide a growing market for farm products. (...) Helping feed the people of underdeveloped countries will become important in the years ahead."
} 
mecanização, é mascarado através da ideia propagada pela economia política vulgar, que difunde a necessidade de corte de custos $^{35}$.

Bird, Arthur e Goldberg (1968) expressam tal visão quando afirmam que:

O aumento dos salários e benefícios dos trabalhadores nos países desenvolvidos, incluindo os Estados Unidos, exercerá pressão sobre as estruturas de custo e esse fator irá também acelerar a tendência à otimização das empresas. (...) As maiores mudanças esperadas são mais equipamentos para poupar trabalho; menor uso relativo de trabalho; e mais investimento de capital em construções, equipamento e infraestrutura. Empresas serão maiores e mais especializadas (BIRD; ARTHUR; GOLDBERG, 1968, p. 3) 3 . $^{36}$.

O documento prevê que a concentração de indústrias processadoras de alimentos demandaria a ampliação da escala do mercado e o aumento dos custos com propaganda e marketing. O texto afirma que:

(...) novas técnicas de processamento requerem máquinas complicadas e caras e futuramente será necessário mais capital na indústria de processamento. (...) Estes fatores tendem a concentrar a indústria nas mãos de poucos. Outro fator que parece afetar a competição no futuro é a promoção nacional de marcas de comidas processadas. (...) uma marca é um instrumento poderosoespecialmente se propagandeada em veículos de alto alcance como os programas nacionais de TV. Então, essas marcas devem ser vendidas nacionalmente e em grandes volumes para justificar os custos promocionais (BIRD; ARTHUR; GOLDBERG, 1968, p. 21)

\footnotetext{
${ }^{35}$ Marx explica que, na interpretação da economia vulgar, os custos aparecem na forma de salário, o que significa obscurecer o trabalho não pago: "Sob a rubrica dos custos, na qual cai o salário tanto quanto o preço de matérias-primas, depreciação de maquinaria, etc., a extorsão de trabalho não-pago aparece apenas como economia no pagamento de um dos artigos que entram nos custos (...). Assim, a extorsão de mais-trabalho perde seu caráter especifico; sua relação específica com a mais-valia é obscurecida; (...) isso é fomentado e felicitado pela representação do valor da força de trabalho na forma de salário" (MARX, Vol. IV, Livro III, Tomo I, 1988, p. 33).

${ }^{36}$ Original em inglês: "Rising wages and additional fringe benefits of labor in developed countries, including the United States, will keep pressure on the cost structures and this factor will also accelerate the trend towards optimized firms. (...) The main changes to be anticipated are more labor saving devices; relatively less labor used; and more capital investment in buildings, equipment, and facilities. Firms will be larger and more specialized".

${ }^{37}$ Original em inglês: "Since many of the newer processing techniques require complicated and expensive machines, the future will bring about higher capital requirements in the food processing industry. (...) Both factors would tend to concentrate the industry in the hands of fewer processors. A third factor that would appear to affect competition in the future is the national promotion of brand processed foods. (...) a brand is a powerful tool—especially if the brand is advertised using the high pressure techniques of national TV programs. Thus, branded items not only have to be sold nationwide; they have to be sold in large volumes to justify their high promotional costs".
} 
A indústria de comida processada foi impulsionada nos Estados Unidos principalmente durante a Segunda Guerra Mundial e era conhecida como "comida de combate" porque servia para alimentar os soldados no exterior. Com o objetivo de apoiar pesquisas neste setor, o Ministério da Defesa dos Estados Unidos criou uma divisão especial, denominada Natick Laboratory, que tinha a função de desenvolver "novos" alimentos. Os primeiros produtos criados neste laboratório foram alimentos enlatados. Posteriormente, foram produzidos alimentos congelados, desidratados e précozidos, além de bebidas solúveis e em pó (BIRD; ARTHUR; GOLDBERG, 1968, p. 26).

De acordo com Bird, Arthur e Goldberg (1968), o Estado exerceu papel central no financiamento e realização deste tipo de pesquisa: "Há pouca dúvida de que a maioria da despesa de tempo e dinheiro eventualmente será compensada, mas a questão é que uma empresa privada não pode arcar com os dólares e anos necessários” (BIRD; ARTHUR; GOLDBERG, 1968, p. 31) ${ }^{38}$.

Além do investimento em pesquisas com "novos" alimentos híbridos, o Estado foi o principal promotor da criação de equipamentos agrícolas, fertilizantes, inseticidas, métodos de transporte e armazenamento para distribuição em massa, além de mecanismos de comunicação e crédito para o agronegócio nos Estados Unidos. Particularmente, as agências envolvidas neste processo eram os Ministérios da Agricultura, Defesa e Interior. Estas agências contrataram um grande número de pesquisadores e fizeram parcerias com universidades, muitas das quais receberam doações de terras públicas para pesquisa e produção agrícolas. Estas universidades ficaram conhecidas como "land grand universities" (BIRD; ARTHUR; GOLDBERG, 1968, p. 46).

A prioridade do Ministério da Agricultura era desenvolver pesquisas em industrialização de alimentos e fibras. O foco da pesquisa no Ministério da Defesa era voltado para métodos de congelamento e desidratação de alimentos, técnicas de irradiação, preservação, empacotamento e armazenamento, inicialmente utilizadas para fins militares. A agência incluía também a fabricação de proteínas, sabores e aromas

\footnotetext{
38 Original em inglês: "there is little doubt that the vast expenditure of time and money will eventually pay off, but the point is that a private firm could not afford the dollars or the years".
} 
sintéticos, além de enzimas para detectar bactérias. Já o Ministério do Interior tinha como linha principal a manipulação de peixes e frutos do mar (BIRD; ARTHUR; GOLDBERG, 1968, p. 47-49).

O relatório de Bird, Arthur e Goldberg (1968) prevê que a ampliação da indústria de comida processada levaria ao incentivo no consumo de refrigeradores, freezers e fornos de micro-ondas, além de outros equipamentos domésticos como abridores de latas, trituradores, liquidificadores e facas elétricas. Este processo incluiria ainda a automatização de serviços como restaurantes fast-food e drive-inns, máquinas de venda, entre outros. Em síntese, significaria mudanças estruturais na indústria de alimentos, com maior índice de mecanização; mais necessidade de capital investido em equipamentos e infraestrutura; maior concentração de capitais através de fusões e aquisições, inclusive de empresas de diferentes setores como alimentos, tabaco, distribuidoras, empresas de alumínio e de eletrônicos. Este processo demandaria um sistema de produção em massa que justificasse a promoção de uma marca em larga escala, o que só poderia ser realizado por grandes empresas com poder de acessar um volume significativo de capital através de subsídios, crédito e de sua atuação nos mercados financeiros (BIRD; ARTHUR; GOLDBERG, 1968, p.42- 44).

Certamente a visão dos promotores do agronegócio não apresentava estes fatores de forma crítica. Pelo contrário, a linguagem utilizada no relatório de Bird, Arthur e Goldberg (1968) enfatiza uma visão ufanista para vender a ideia de um futuro próspero, principalmente para a classe média nos Estados Unidos e em especial para as mulheres. Alguns trechos do texto chegam a ser cômicos, quando apresentam a perspectiva futurista dos autores para as décadas seguintes. A citação do diretor da Comissão de Energia Atômica, Glenn Seaborg, utilizada para dar credibilidade à propaganda otimista de futuro, merece ser reproduzida:

O tempo de trabalho doméstico será reduzido e as esposas poderão devotar mais atenção a atividades fora de casa. Muitos lares terão cozinhas automatizadas. A dona de casa poderá preparar o cardápio para a semana seguinte, armazenar a comida necessária, e dar instruções a um computador. Em um momento prédeterminado, braços mecânicos irão selecionar, cozinhar e servir a comida. (...) Um empregado robô, treinado para atender as necessidades de uma determinada casa, poderá ser programado para realizar as tarefas domésticas básicas. Se a dona de casa do século 21 preferir serviçais vivos, ela terá essa escolha. (...) É possível que algumas espécies inteligentes de animais, como macacos, façam este trabalho manual. As casas que não tiverem um robô no armário das vassouras poderão ter um 'hóspede macaco' para fazer a limpeza e cuidar das crianças. Os homens poderão utilizar macacos bem treinados como motoristas 
da família, para cortar a grama, tirar a neve ou como ajudantes de golfe (In BIRD; ARTHUR; GOLDBERG, 1968, p.45) ${ }^{39}$.

É difícil imaginar que este tipo de pensamento, elaborado pelo diretor da Comissão de Energia Atômica dos Estados Unidos, poderia ser levado a sério e reproduzido em um documento técnico com o objetivo de assessorar políticas governamentais. Entretanto, este conjunto de ideias está de acordo com a percepção do que seria o chamado "sonho americano", ou seja, a noção de uma sociedade em constante "evolução", onde tudo funciona perfeitamente e, caso algo fuja à regra, seria um problema de falta de esforço ou disfunção pessoal.

Na década de 1970, outra estratégia do governo estadunidense em apoio ao agronegócio se expressa através das negociações do acordo de livre comércio conhecido como GATT (General Agreement on Tariffs and Trade), que tinha o objetivo de garantir maiores vantagens para suas exportações agrícolas. Um dos pontos centrais das negociações era a necessidade de manter controle sobre os estoques mundiais de grãos. Desta forma, o país poderia manter a possibilidade de especular com essas commodities, fomentando o aumento das exportações em um período de alta dos preços no mercado internacional e promovendo dumping em outros países quando o cenário era de queda dos preços. Burbach e Flynn descrevem o papel das exportações agrícolas e das políticas de "ajuda humanitária alimentar" como "uma arma importante no arsenal da política externa dos Estados Unidos” (BURBACH; FLYNN, 1980, p. 63).

O governo estadunidense se utilizou de diferentes mecanismos para lidar com a crise de superacumulação no setor agrícola a partir do período pós-guerra. A legislação conhecida como PL 480 (Public Law 480), aprovada em 1954, permitia que o montante equivalente ao envio de grãos fosse adquirido em moeda local pelos países importadores, através de crédito subsidiado do próprio governo estadunidense. Esta

\footnotetext{
${ }^{39}$ Original em inglês: "Housework will take less time and wives can devote more attention to activities outside the home. Many homes will have automated kitchens. The housewife may make out her menu for the coming week, put the necessary foods in storage spaces, and give instructions to her computer. At the prescribed time mechanical arms will select, cook, and serve the food. (...) A robot maid, trained to the requirements of a particular home, may be programmed to carry out standard household operations. If the housewife of the $21^{\text {st }}$ century prefers animated servants she may have a choice. (...) We may find it feasible to breed intelligent species of animals, such as apes, to perform manual labor. Houses not having a robot in the broom closet could have a 'live-in-ape' do the cleaning and babysitting. Men may find well-trained apes useful as family chauffeurs, lawn mowers, snow shovelers, or even as golf caddys."
} 
medida beneficiou principalmente empresas multinacionais do agronegócio que utilizaram a nova política para se instalar em diversos países, o que estimulou a desestruturação da produção local de alimentos, gerando dependência econômica e favorecendo regimes leais aos interesses do governo norte-americano. Na Ásia, por exemplo, a prioridade foi financiar a compra de grãos pelos governos do Vietnam do Sul, da Coréia do Sul e do regime de Ferdinando Marcos nas Filipinas. No Oriente Médio, a "ajuda alimentar" foi fundamental para que os Estados Unidos pudessem conquistar o apoio do Egito contra a luta pela criação do Estado palestino. Na América Latina, essa política serviu para fortalecer o regime de Augusto Pinochet no Chile (BURBACH; FLYNN, 1980, p. 70-77).

A exportação agrícola, portanto, se constituiu como peça fundamental, tanto para a economia quanto para o jogo da política externa dos Estados Unidos, que tinha o objetivo de intensificar acordos de abertura comercial para seus produtos. No período pós-guerra, o país passou a controlar metade de todo o volume das exportações mundiais de grãos. Além dos mercados europeu e japonês, prioritários durante o período de "reconstrução" pós-guerra, o acesso ao mercado soviético era fundamental. Em 1972, a União Soviética importou 18 milhões de toneladas de trigo dos Estados Unidos. Este montante representava um quarto da safra estadunidense de trigo naquele ano, o que gerou forte aumento do preço das commodities agrícolas, favorecendo o agronegócio e principalmente empresas como Cargill, Continental Grain, Dreyfus e Cook Industries, que se beneficiaram com a demanda soviética e com o aumento do preço dos grãos no mercado internacional (BURBACH; FLYNN, 1980, p. 50-52).

Nos anos posteriores, os Estados Unidos estabeleceram um acordo que garantia no mínimo a exportação anual de seis milhões de toneladas de grãos para a União Soviética. Em 1979, as exportações de milho e trigo dos Estados Unidos para o mercado soviético chegaram a 25 milhões de toneladas. Tal conjuntura iria se modificar no final daquele ano, em consequência do acirramento do conflito entre os dois países no Afeganistão. Naquele período, o governo de Jimmy Carter suspendeu o acordo de exportação de grãos para a União Soviética e passou a comprar o excedente dos agricultores que dependiam do mercado soviético (BURBACH; FLYNN, 1980, p. 60).

A interrupção das exportações de grãos para a União Soviética teve grande impacto durante os anos 1980, que se caracterizaram pela diminuição da produção 
agrícola estadunidense. Outro fator determinante para a queda da produtividade foi o aumento do custo deste modo de produção, que se tornou altamente dependente do uso intensivo de fertilizantes químicos e outros insumos à base de petróleo, o que gerou ainda a degradação dos melhores solos (BURBACH; FLYNN, 1980, p. 130).

Além de exercer um papel central na política externa, o modelo de agricultura extensiva determinou a legislação migratória dos Estados Unidos desde o início do século 20. Em 1917, o governo adotou medidas para facilitar a contratação de imigrantes mexicanos, principalmente na Califórnia. Estima-se que em 1920 o número de trabalhadores mexicanos nas lavouras do estado era de 70 mil e, em 1940, chegou a 400 mil. Durante a Segunda Guerra Mundial, outro acordo entre os governos do México e Estados Unidos criou o programa bracero, que estimulou uma nova onda de migração de trabalhadores rurais. Em 1965 o número de braceros em todo o país chegou a 450 mil e representava a maioria da força de trabalho no campo. Estes trabalhadores eram contratatos somente durante o período de safra, diretamente pelo governo e não pelas empresas. Enfrentavam condições degradantes e viviam em habitações improvisadas. Durante os 25 anos de duração do programa-que teve início em 1942 e continuou durante toda a chamada golden age (era de ouro), caracterizada pela modernização do agronegócio estadunidense —o salário dos braceros aumentou de US\$0,75 para apenas US\$1,25 por hora. Sua função, portanto, era garantir que a remuneração dos assalariados rurais permanecesse em um patamar mínimo (WALKER, 2004, p. 71-72).

\section{$\underline{\text { A influência da "economia evolucionária" na concepcão do agronegócio }}$}

No sentido de contextualizar a ideologia predominante no período pós-guerra e em particular o discurso em defesa do "desenvolvimento" do agronegócio, buscamos analisar a influência exercida pelo economista Kenneth E. Boulding, citado por John Davis e Ray Goldberg em seu livro The Concept of Agribusiness.

Boulding foi defensor da chamada "economia evolucionária" e acreditava que as leis econômicas seguiam o caminho do desenvolvimento biológico, através do "progresso tecnológico". Segundo ele, progresso econômico significaria desenvolvimento tecnológico e representaria:

(...) o mais importante elemento do sistema econômico (...) em contraste com as sociedades selvagens que mantêm os mesmos costumes, técnicas por gerações. (...) Nas sociedades civilizadas modernas, por outro lado, ocorrem mudanças 
constantes; estamos sempre melhorando nossos métodos (...) temos a sensação de grande superioridade tecnológica (...) progresso econômico não é uma coisa vaga e irreal, mas uma experiência real da humanidade, que pode ser experimentada mesmo durante o período de vida de um indivíduo (BOULDING, 1958, p. 22).

A noção de "progresso" e "desenvolvimento" sempre crescentes, movidos pela invenção de novas tecnologias, pressupõe que o "novo" ou o "futuro" será sempre superior e benéfico, como mostra a seguinte afirmação: "sempre que substituímos um método antigo por um novo método de fazer as coisas, comprovadamente melhor, ocorre progresso econômico. (...) Progresso econômico diz respeito somente aos meios, não à finalidade" (BOULDING, 1958, p. 23).

Para tentar explicar a relação entre desenvolvimento econômico e tecnologia, Boulding faz uma interpretação simplista da teoria de Adam Smith, que ilustra o tipo de pensamento que Marx denominou de economia vulgar, como verificamos na citação seguir:

Desenvolvimento econômico consiste naquilo que Adam Smith chamou de produtividade do trabalho. Significa que os homens podem produzir mais no mesmo período de tempo. (...) Outro fator para o desenvolvimento econômico seria a economia de tempo no processo de aprendizagem, já que só seria necessário aprender uma função específica no processo produtivo. Mas o fator mais importante, segundo Smith, seria o desenvolvimento de máquinas e do papel da ciência aplicada para melhorar os métodos da produção (BOULDING, 1964, p. 50).

De acordo com Boulding, a imagem do mundo "civilizado" e científico estaria relacionada à vida urbana e deveria triunfar devido à sua "superioridade": "O poder superior das imagens científicas geralmente asseguram o triunfo da imagem científica em competição com a imagem folclórica, mas mesmo assim a batalha deverá ser longa e dolorosa" (BOULDING, 1964, p. 56-57) ${ }^{40}$. O autor imagina que o desenvolvimento tecnológico teria a incrível capacidade de gerar uma espécie de bem-estar universal, onde não haveria espaço para a luta de classes. Este tipo de pensamento foi difundido também por seguidores da teoria keynesiana, como explica Mészáros (2004):

Keynes descreve o processo da reprodução produtiva de uma perspectiva 'materialista vulgar' mecanicista daquilo que ele próprio denomina 'a máquina econômica', declarando com otimismo ilimitado que a ciência, a eficiência

\footnotetext{
${ }^{40}$ Original em inglês: "The superior power of scientific images usually ensures the triumph of the scientific image over the competing folk image, but nevertheless the struggle may be long and painful".
} 
técnica e a acumulação de capital (...) estão perto de resolver, 'gradualmente', é claro, o 'problema econômico da humanidade (MÉSZÁROS, 2004, p. 61).

A crença em um tipo de crescimento linear e benéfico seria confrontada por fatores que Boulding chamou de "dificuldades de desenvolvimento econômico para os países pobres". A justificativa utilizada para explicar tal dificuldade seria atribuí-la ao:

(...) crescimento muito rápido da população nas cidades, às vezes pela chegada de refugiados de guerra ou realocação de fronteiras, e quase sempre porque o crescimento rápido da população nas áreas rurais força as pessoas dessas áreas para as cidades, simplesmente porque a economia rural só comporta um número constante de força de trabalho (BOULDING, 1966, p. 226) ${ }^{41}$.

A doutrina que tentou explicar as mazelas da sociedade através do argumento de que decorreriam do aumento populacional foi predominante no período pós-guerra, como revela a seguinte afirmação de Boulding:

Um dos problemas mais difíceis que a humanidade enfrenta no presente momento histórico é o controle de sua população. (...) a melhora na saúde da população e especialmente na saúde das crianças pode ser um desastre. (...) Quando a população de crianças e jovens é muito grande, torna-se mais difícil conceder recursos para educação, que são necessários para a sociedade passar para o mundo moderno (BOULDING, 1964, p. 121-123) ${ }^{42}$.

De acordo com este tipo de pensamento, não haveria contradição de classe na sociedade. $\mathrm{O}$ autor interpreta o processo de acumulação do capital como se fosse uma simples diferença entre o montante de bens produzidos e consumidos durante determinado período, ou como se o problema da acumulação se restringisse a fenômenos de oferta e procura. Segundo ele:

Produção é o processo que adiciona ativos a um montante total. Consumo é o processo que subtrai desse montante total. A diferença entre o índice de produção e o índice de consumo pode ser chamada acumulação real; é o índice de crescimento dos ativos (BOULDING, 1966, p. 13) ${ }^{43}$.

\footnotetext{
${ }^{41}$ Original em inglês: "This is due mainly to the very rapid growth in population of the cities, sometimes because of refugees from war or from relocation of frontiers, and almost always because of the rapid population increase in rural areas forces people out of these areas into the cities, simply because the rural economy is only adjusted to a fairly constant labor force".

${ }^{42}$ Original em inglês: "One of the most difficult problems facing mankind in the present historical era is the control of its own population. (...) a sudden improvement in the health of the people and especially in the health of children could prove to be a disaster. (...) When there is a very large population of children and young people, it becomes increasingly difficult to provide the resources for the kind of education which is necessary if society is to pass over into the modern world".
}

43 Original em inglês: "Production is the process of adding to the total inventory of stock. Consumption is the process of subtracting from this total inventory. The difference between the 
A análise de Marx desmonta a percepção de que a produção capitalista funcionaria a partir da relação entre oferta e procura, ou seja, de que as mercadorias tivessem a função de cumprir uma necessidade social. Este tipo de argumento serve para esconder o processo social através do qual a mais-valia se transmuta e aparece de forma positivada como salário, lucro ou renda da terra:

Note-se aqui de passagem que a 'necessidade social', isto é, o que regula o princípio da procura, é essencialmente condicionada pela relação das diversas classes entre si e por sua respectiva posição econômica, nomeadamente portanto, primeiro, pela proporção entre a mais-valia global e o salário e, segundo, pela proporção entre as diversas partes em que a mais-valia se divide (lucro, juros, renda fundiária, impostos, etc.); e assim evidencia-se também mais uma vez que absolutamente nada pode ser explicado pela relação entre procura e oferta (MARX, Vol. IV, Livro III, Tomo I, 1988, p. 134).

A influência das ideias de Boulding aparece com frequência no discurso dos promotores do agronegócio. De acordo com John Davis, a transformação da agricultura em negócio seria um processo evolutivo e inevitável, ocasionado pelo crescente melhoramento tecnológico. $\mathrm{O}$ trecho a seguir expressa tal visão:

Em geral, os porta-vozes de grandes interesses econômicos - incluindo líderes rurais, empresários, membros do governo, e mesmo especialistas profissionais tem demorado a compreender a magnitude das forças evolutivas que convertem agricultura em agronegócio e problemas agrícolas em problemas empresariais. Eles têm demorado a reconhecer a inevitabilidade das mudanças inerentes à aplicação de melhores tecnologias - mudanças como o aumento das unidades, organização, competência gerencial, conhecimento técnico, necessidade de capital, e potencial de mercado (DAVIS, 1957, p. 173) ${ }^{44}$.

A necessidade de relacionar a noção de "desenvolvimento" como um processo sempre crescente de evolução tecnológica está presente no discurso dos autores que continuaram a disseminar o conceito de agronegócio, após o início do uso do termo elaborado por Davis e Goldberg. É recorrente também, na análise de diversos autores, inclusive de Davis e Goldberg, o reconhecimento de fatores que indicam a permanência

rate of production and the rate of consumption may be called the rate of real accumulation; it is the rate at which the stock is increasing".

${ }^{44}$ Original em inglês: "In general, the spokesmen for major economic interests-including farm leaders, businessmen, public officials, and even professional experts-have been slow in comprehend the magnitude of the evolutionary forces which are converting agriculture into agribusiness and farm problems into business problems. They have been slow to recognize the inevitability of the changes which are inherent in the application of improved technologychanges in such factors as the size of unit, organization, managerial competence, technical skills, capital requirements, and market potentials". 
da crise na formação e expansão do agronegócio. Tais fatores, que avaliamos de forma crítica, são frequentemente apresentados por ideólogos do agronegócio como consequências naturais no processo de industrialização da agricultura.

Ao contrário de tal perspectiva, esta tese considera a relação capital-trabalho como fator central para o entendimento das contradições do modo capitalista de produção na agricultura. A análise da relação capital-trabalho, centrada no processo produtivo e não na simples relação de oferta e procura, revela o movimento de desequilíbrio na composição orgânica do capital na agricultura, com o aumento da parte constante em relação ao trabalho vivo a ser explorado. Ou seja, a chamada "industrialização" da agricultura gera aumento do capital constante em relação à possibilidade de exploração de mais-valia, que se constitui como única fonte de valorização do capital. A formação de monopólios expressa a determinação crítica deste processo e retroalimenta a crise, já que elimina a concorrência como força motora do desenvolvimento das forças produtivas e do próprio modo capitalista de produção. Portanto, este processo será necessariamente crítico, já que indica a impossibilidade de valorização do capital, que passa a depender dos sistemas de crédito e subsídios, ou do capital fictício, para se reproduzir.

Os porta-vozes do agronegócio, por sua vez, tentam explicar a formação de monopólios através da ideia da necessidade de "integração vertical e horizontal". Um exemplo deste tipo de discurso está presente no livro Exploring Agribusiness, uma espécie de publicação didática que serviu para propagandear o conceito de agronegócio no meio acadêmico. O seguinte trecho é emblemático:

O valor total comercializado pelos agricultores tem se mantido estável por muitos anos, mas como o número de agricultores tem decrescido, as vendas per capta aumentaram. Ou seja, a mesma torta é dividida entre um menor número de pessoas. Essa é uma boa tendência, porque significa que a renda agrária está se igualando à renda mais elevada nas ocupações não agrícolas. Mesmo o número de trabalhadores utilizados para o trabalho rural temporário tem declinado com sua substituição por máquinas. Outro fator que influi na renda dos agricultores é o aumento de programas governamentais que exercem o efeito de estabilização da renda agrícola (ROY, 1967, p. 12-13) ${ }^{45}$.

\footnotetext{
${ }^{45}$ Original em inglês: "The total value of farmers' marketing has stayed about the same for several years, but as the number of farmers has decreased, sales per capita have increased. That is, the same pie is divided among fewer people. This is a good trend, because it means that per capita farm incomes are trying to keep pace with higher per capita incomes in non-farming occupations. Even the amount of hired labor used for seasonable farm work is declining as farmers substitute machines for hand-labor. Another factor in farmers' income is the increasing
} 
Ainda de acordo com Roy (1967), os agricultores passaram a depender de insumos comprados de outras empresas, que substituíram os insumos antes desenvolvidos e produzidos na própria unidade agrícola. Por exemplo, dados da década de 1960 mostram que a quantidade de aço utilizada nas fazendas dos Estados Unidos era equivalente àquela necessária para a produção de cinco milhões de carros compactos. A quantidade de borracha seria maior do que a necessária para a fabricação de pneus para seis milhões de carros. O consumo de petróleo pelo agronegócio era maior do que o de qualquer outro setor, chegando a 15 bilhões de barris por ano. $\mathrm{O}$ autor observa que estes gastos demandavam linhas de crédito especiais por parte do governo (ROY, 1967, p. $11)$.

Roy reconhece ainda que o aumento da mecanização na agricultura dos Estados Unidos, entre 1910 e 1960, foi inversamente proporcional à utilização de força de trabalho, enquanto a área cultivada não se expandiu. Segundo o autor:

Quando consideramos terra, trabalho e capital como os principais fatores na produção agrícola, é evidente que a terra se mantém constante. Sua contribuição é cerca de $8,5 \%$ do total. O trabalho, por outro lado, diminuiu mais da metade, contribuindo com cerca de $30 \%$ atualmente, em comparação com 75\% em 1910. O item capital (infraestrutura, animais, máquinas, equipamentos, crédito, etc.) quadruplicou, contribuindo $61 \%$ no presente, em comparação com somente $17 \%$ em 1910. (...) a ênfase maior em especialização da pesquisa substitui as tecnologias descobertas pelos próprios agricultores (ROY, $1967 \mathrm{p}$. $25-26)^{46}$.

Outras atividades que antes eram realizadas nas próprias fazendas, como armazenamento, processamento e distribuição de alimentos e fibras, foram transferidas para grandes empresas. De acordo com Roy (1967), a maior concentração de capitais no agronegócio passou a se formar na indústria de embalagens, principalmente nos setores de enlatados, vidros, tubos e papel; assim como nos setores de fertilizantes, pneus e refinamento de petróleo. O autor observa que "Atualmente a economia do agronegócio

size of federal payments under various agricultural programs, which have the effect of stabilizing farm income".

${ }^{46}$ Original em inglês: "When we consider land, labor and capital as the prime factors in farm inputs, it is evident that land remains constant. Its contribution is about 8.5 per cent of the total. Labor, on the other hand, has dropped by more than a half, contributing about 30 per cent at present, compared with 75 per cent in 1910. Capital items (buildings, livestock, machinery, equipment, credit funds, etc.) have about quadrupled, contributing 61 per cent at present, compared with only 17 per cent in 1910 . (...) an increase in farm technology which puts more emphasis on specialization and research findings rather than on farmer-discovered technology". 
surge da difusão gradual das funções de agricultura para negócio” (ROY, 1967, p. 41$42)^{47}$.

Em relação à propriedade e uso da terra, o estudo de Roy (1967) mostra que, na década de 1960, 20\% do território dos Estados Unidos estavam destinados à agricultura, enquanto $28 \%$ eram utilizados para pastagens, $34 \%$ estavam cobertos por florestas e o restante de $18 \%$ era destinado para outros fins. Entre as décadas de 1940 e 1960, e principalmente com a crise de superprodução do período pós-guerra, 30 milhões de acres de áreas agrícolas foram reconvertidos em florestas e pastagens. As terras públicas, que representam cerca de um terço do país, passaram a ser reservadas para a conservação das florestas, consideradas indispensáveis para a produção de matérias primas, para a manutenção da fertilidade do solo, da umidade e da preservação dos rios, além de evitar enchentes e outros desastres naturais.

De acordo com o Censo Agrícola da década de 1960, das cerca de 3.5 milhões de propriedades rurais, um terço eram consideradas familiares, apesar da tendência de concentração de terras em grandes fazendas. Porém, as chamadas family farms, onde pelo menos $50 \%$ do trabalho realizado era tarefa de membros da família camponesa, aumentaram sua importância na produção agrícola daquele período, com $70 \%$ do total comercializado, em comparação com 66\% em 1944. Dos cerca de 400 milhões de acres utilizados para a agricultura, apenas 150 mil fazendas eram consideradas grandes propriedades. Porém, estas fazendas se tornaram mais especializadas e menos diversificadas, com o propósito de atender à demanda da produção de monocultivos para o agronegócio (ROY, 1967, p. 43-45).

O livro Agribusiness in Latin America (1974) é outro exemplo da influência de Ray A. Goldberg no meio acadêmico e em especial na América Latina. O autor, James Austin, foi professor da Harvard University Business Administration e do Instituto Centro-Americano de Administração de Empresas, onde foi diretor do Programa de Pós-Graduação em Agronegócio (Graduate School’s Agribusiness Program). Segundo seu resumo biográfico, trabalhou como consultor de agências internacionais e de diversas empresas do agronegócio na América Latina (AUSTIN, 1974, p. 312).

\footnotetext{
${ }^{47}$ Original em inglês: "The present agribusiness economy has come about by the gradual dispersion of functions from agriculture to business".
} 
No livro, o termo "agronegócio" é definido como um "sistema", que incluiria três componentes. O componente "operacional" seria composto por agricultores, empresas processadoras, empresas de armazenamento e distribuição. O segundo componente reuniria empresas de insumos, bancos de crédito e institutos de pesquisa. $\mathrm{O}$ terceiro componente deste sistema envolveria mecanismos de "coordenação", que incluiriam órgãos de governo, mecanismos jurídicos e contratuais, associações empresariais e mercados de futuro. O prefácio do livro, escrito por Ray Goldberg, enfatiza o mito de que a expansão do agronegócio seria a solução para a escassez mundial de alimentos, como na citação a seguir:

A atual escassez de comida em nível global demonstra que apesar do impressionante progresso tecnológico nos últimos anos, o mundo não está livre da séria ameaça da falta de alimentos. (...) em muitos países em desenvolvimento, o potencial agrícola tem sido desperdiçado pela inabilidade de levar tecnologias mais modernas e gerenciamento para resolver problemas de produção, processamento, armazenamento, distribuição e marketing. O Agribusiness Council, uma organização sem fins lucrativos a qual eu tenho a honra de servir como diretor, está dedicada a levar recursos e capacidades para empresas do agronegócio com a finalidade de gerar desenvolvimento econômico (AUSTIN, 1974, p. VI) ${ }^{48}$.

O livro de Austin (1974) segue a mesma abordagem de outros porta-vozes do setor que defendem a difusão do agronegócio em âmbito internacional e particularmente na América Latina. $\mathrm{O}$ autor considera que a agricultura para exportação deveria se manter como principal atividade econômica nos países latino-americanos. Seu estudo estima que $15 \%$ de toda a terra agrícola da região estariam voltados para a produção de quatro commodities - café, açúcar, banana e algodão. Na opinião de Austin, a economia latino-americana se beneficiaria com o aumento do nível de "industrialização" da agricultura. Entretanto, dados coletados pelo autor mostram que a produção de alimentos na América Latina cresceu apenas 1,9\% entre as décadas de 1950 e 1960, quando se impulsiona o modelo da chamada "revolução verde". Os argumentos

\footnotetext{
${ }^{48}$ Original em inglês: "The current global food scarcities and the concomitant rise in food prices demonstrate that in spite of the impressive progress made in agricultural technology in recent years, the world is not free from the treat of serious crop shortfalls. (...) in many of the developing countries, agricultural potential is being wasted because of the inability to bring more modern technology and management to bear on the problems of production, processing, storage, distribution, and marketing. The Agribusiness Council, a nonprofit, membership organization of which I have the honor to serve as chairman, is dedicated to bringing the resources and capabilities of agribusiness firms to bear on economic development".
} 
utilizados para explicar a "ineficiência" da produção agrícola nos países latinoamericanos voltam a defender a necessidade de maiores investimentos em tecnologia. $\mathrm{O}$ livro aponta ainda como causa da baixa produtividade a incapacidade de expansão do mercado interno devido aos baixos salários dos trabalhadores e a falta de treinamento adequado para gerenciar setores do agronegócio como um "sistema" integrado. Como forma de superar esta necessidade de treinamento, o autor sugere que seu livro serviria como instrumento para a "formação em agronegócio" na América Latina (AUSTIN, 1974, p. 4-6).

\section{$\underline{\text { A utilização do conceito de agronegócio no pensamento neo-malthusiano }}$}

O conceito de agronegócio, difundido inicialmente por Davis e Goldberg (1957), foi incorporado em uma série de publicações posteriores. Uma destas publicações, intitulada Agricultural Economics and Agribusiness (2001), define agronegócio como: “o total de operações envolvendo desde a manufatura até a distribuição de produtos agrícolas; produção nas fazendas; e armazenamento, processamento e distribuição de commodities agrícolas e itens feitos a partir destes" (CRAMER; JENSEN; SOUTHGATE, 2001, p. 9) ${ }^{49}$.

O livro traz como referência teórica o chamado "princípio da população", que está baseado no pensamento de Thomas Malthus, segundo o qual a expansão populacional levaria à humanidade a uma situação de "catástrofe" devido à impossibilidade de aumento da produção de alimentos na mesma proporção. Segundo os defensores do agronegócio, tal catástrofe poderia ser evitada com a expansão da atividade agrícola através da "abertura de novas terras", além do aumento do nível de mecanização e da produtividade da agricultura que, de acordo com este argumento, seria impulsionada pela expansão do uso de máquinas, fertilizantes e pesticidas (CRAMER; JENSEN; SOUTHGATE, 2001, p. 488-490).

Os autores estimam que $50 \%$ de todos os ativos das empresas estadunidenses fossem compostos por setores do agronegócio que, segundo eles, incluiria tanto grandes empresas quanto pequenos agricultores, instituições de crédito, empresas de insumos,

49 Original em inglês: "the sum total of all operations involved in the manufacture and distribution of farm supplies; production operations on the farm; and the storage, processing and distribution of farm commodities and items made from them". 
transporte e distribuição, assim como redes de supermercados e restaurantes. Em relação ao uso da terra, explicam que apesar do processo da concentração fundiária que ocorreu a partir do período pós-guerra, dados de 1987 mostram que as chamadas family farms (propriedades da agricultura familiar) representavam $87 \%$ das fazendas nos Estados Unidos. Ainda de acordo com o estudo, a principal característica que teria marcado o processo de "integração" dos agricultores familiares com o agronegócio seria a "especialização" ou a padronização da agricultura que passou a priorizar os monocultivos. ${ }^{50}$ Por outro lado, os autores identificam um crescente movimento de concentração econômica e formação de monopólios nas empresas de insumos, distribuição e comercialização agrícola (CRAMER; JENSEN; SOUTHGATE, 2001, p. 24).

O mito da escassez de alimentos, típico do pensamento neomalthusiano, é utilizado no livro para justificar a necessidade de expansão das exportações agrícolas pelos Estados Unidos. O livro defende a política estadunidense de assegurar preços elevados para o agronegócio em âmbito nacional, mesmo que seja através de dumping, ou seja, de exportações subsidiadas para outros países:

Devido à capacidade excedente dos Estados Unidos, o mercado exportador tem sido importante para o setor agrícola. No passado, as exportações se deram como dumping do excedente da produção, mas com as mudanças recentes na demanda por commodities agrícolas, parece que as empresas do agronegócio terão a oportunidade de melhorar suas vendas no mercado externo. Esse mercado torna-se especialmente relevante se a escassez de comida continuar em nível mundial e os controles da produção nos EUA não forem necessários para manter a renda agrícola (CRAMER; JENSEN; SOUTHGATE, 2001, p.455) ${ }^{51}$.

É possível identificar traços semelhantes nas análises dos ideólogos do agronegócio. Uma ideia recorrente se expressa na atribuição de conotação positiva ao

\footnotetext{
${ }^{50} \mathrm{O}$ aumento da concentração fundiária nos Estados Unidos se expressa pela diminuição do número de fazendas, que passou de 6.8 milhões em 1935 para cerca de 3 milhões em 1970, mantendo-se a mesma quantidade de terra cultivada. Ou seja, apesar da permanência de um número significativo de agricultores familiares, verifica-se a expansão de grandes propriedades rurais (COCHRANE, 1993, p. 132-133).

${ }^{51}$ Original em inglês: "Because of the excess capacity in the United States, the export market has been important for the agricultural sector. In the past, the export market has been a place to dump surplus production, but with the recent changes in the demand for agricultural commodities it appears that agribusiness firms will have an opportunity to sell more of their output in foreign markets. This market is especially relevant if worldwide food shortages continue to exist and production controls on U.S. agriculture are not needed to maintain farm income".
} 
avanço do modelo conhecido como "sistema do agronegócio", que é apresentado como solução para a fome no mundo, ocasionada, segundo eles, pelo aumento populacional. Outro argumento comum na defesa da expansão do agronegócio, principalmente a partir do período pós-guerra, se expressa no ufanismo em relação a possibilidades de "avanço tecnológico" como solução para resolver as situações de fome e crise na agricultura. Estas "novas" tecnologias, apresentadas como solução para aumentar a produtividade agrícola, incluiriam setores de maquinário, indústrias químicas e de biotecnologia. Porém, apesar de não abandonarem a defesa do avanço tecnológico como suposta fórmula mágica, a partir dos anos 1980 a própria conjuntura de crise força os analistas do agronegócio a estabelecerem algumas mudanças em seu discurso. Um exemplo de tal pensamento está presente na seguinte citação:

O valor do DDT como inseticida foi descoberto em 1939 pelo Dr. Paul Muller, que recebeu o Prêmio Nobel de Psicologia e Medicina em 1948. O DDT foi um dos principais componentes utilizados para controlar o mosquito da malária durante a II Guerra Mundial, e sua efetividade encorajou pesquisadores a desenvolver componentes semelhantes (...) de valiosos inseticidas. Ironicamente, muitos dos mais bem sucedidos pesticidas, que eram tão promissores inicialmente, tornaram-se inimigos do meio ambiente. (...) muitos devem ser declarados ilegais no futuro próximo (RAWLINS, 1980, p. 69$)^{52}$.

Entretanto, a explicação neomalthusiana para o problema da fome não é abandonada e parece ganhar força entre os defensores do agronegócio na década de 1970. Naquele momento de conjuntura de crise do capitalismo em nível mundial, que se expressa como "crise do petróleo", verifica-se que os preços das commodities agrícolas disparam principalmente em consequência do alto custo dos insumos a base de petróleo. Outro fator relevante foi o aumento do fluxo do comércio internacional de grãos, principalmente com os acordos de grandes volumes de exportação dos Estados Unidos para a União Soviética. Apesar de estes fatores serem bastante conhecidos, prevalece no discurso oficial, tanto de governos quanto dos porta-vozes do agronegócio, a visão simplista que procura justificar a fome no mundo como consequência do aumento populacional. Tal ideologia serviu inclusive para facilitar o fomento de políticas de

\footnotetext{
${ }^{52}$ Original em inglês:"The value of DDT as an insecticide was discovered in 1939 by Dr. Paul Muller for which he received the 1948 Nobel Prize in Physiology and Medicine. DDT was the major compound used to control malaria mosquitoes during World War II, and the effectiveness of this compound encouraged researches to develop other similar compounds as (...) valuable insecticides. Ironically, many of the most successful pesticides which provided so much promise in earlier years have become enemies of the environment. (...) numerous others will likely be declared illegal in the near future".
} 
controle de natalidade e esterilização forçada de mulheres em diversos países da América Latina, África e Ásia, financiadas por agentes estatais, como o Banco Mundial e USAID, e privados, como as fundações Ford e Rockefeller (BURBACH; FLYNN, 1980, p. 9-13).

Burbach e Flynn (1980) identificam o início do processo de “internacionalização" do agronegócio a partir da disseminação de sementes híbridas no México, desenvolvidas por Nelson Borlaug, conhecido como "pai" da chamada "revolução verde". O cultivo desse tipo de semente demandava todo um "pacote" tecnológico, que incluía desde estruturas de mecanização até irrigação e uso de fertilizantes químicos e de pesticidas (BURBACH; FLYNN, 1980, p. 116). Um marco na promoção da "revolução verde" foi a concessão do Prêmio Nobel da Paz para Norman Borlaug em 1970. Naquele período Borlaug trabalhava para o Centro de Melhoramento de Milho e Trigo (CIMMYT) no México, uma instituição financiada pela Fundação Rockefeller (PERELMAN, 1979, p. 143).

A ideia da necessidade de "industrialização" da agricultura ou da “internacionalização" do agronegócio, através de políticas de apoio à implantação deste sistema em nível mundial, continua a ser justificada como solução no combate à fome. Para isso, foi necessário difundir a noção de "desenvolvimento" da agricultura, associada à extensão territorial e aos processos de mecanização e padronização dos cultivos, que demandam grande quantidade de capital. A partir deste argumento, se justifica a expropriação da agricultura camponesa, com o propósito de aumentar tanto a disponibilidade de terra quanto de proletários rurais. Nos países do chamado Terceiro Mundo, a estratégia principal do governo estadunidense para promover o agronegócio foi gerar dependência especialmente em relação a insumos agrícolas e a canais de comercialização, controlados por grandes empresas (BURBACH; FLYNN, 1980, p. 4647).

Autores como Goodman, Sorj e Wikinson (1987) elaboram uma análise crítica sobre a formação do chamado "complexo agroindustrial” e sua internacionalização. Eles partem do princípio de que a substituição dos insumos de base natural por insumos químicos permitiu a reprodução de setores industriais e a transferência de valor da agricultura para a indústria, expandindo possibilidades de acumulação de capital. Os autores explicam que: 
Apesar do problema dos alimentos perecíveis, as commodities agrícolas, depois de colhidas, funcionam como qualquer outra matéria prima usada na indústria. As empresas de processamento geralmente surgem relacionadas com o capital comercial, como no caso do trigo e da farinha (...). Ou seja, sem a capacidade de sujeitar a produção rural na totalidade, algumas atividades rurais tornaram-se setores de acumulação de diferentes frações do capital industrial (GOODMAN; SORJ; WIKINSON, 1987, p. 6-7) ${ }^{53}$.

Além das matérias primas agrícolas, a indústria de processamento de alimentos passa a utilizar maiores quantidades de materiais químicos e sintéticos, através de fusões com o setor farmacêutico e petroquímico. Principalmente no período pós-guerra se intensifica a internacionalização das empresas do agronegócio, muitas vezes através de fusões e aquisições de empresas menores. A comercialização de novas marcas de comida processada gerou a necessidade de enormes gastos em propaganda, com o objetivo de criar a chamada "diferenciação do produto". Algumas empresas que detêm o monopólio deste mercado são, por exemplo, Unilever e Nestlé. Os monopólios estabelecidos nos setores de processamento e distribuição ampliam também a tendência de concentração de capitais para o setor de vendas a varejo, com a criação dos supermercados, que muitas vezes criam marcas próprias de produtos através de fusões e contratos especiais com fornecedores. Tal processo favorece contratos de promoção e propaganda de determinadas marcas. Este período marca uma crescente padronização no mercado internacional de alimentos, controlado por oligopólios multinacionais. Grandes redes de supermercados estadunidenses e europeias se instalaram nos países do hemisfério Sul. Outro desdobramento deste processo foi a multiplicação das lojas de conveniência e restaurantes fast-food (GOODMAN; SORJ; WIKINSON, 1987, p. 80$81)$.

\section{Análise histórica do conceito de agribusiness}

Entre 1950 e 1981, o comércio internacional agrícola teve uma expansão de 14\%. Entretanto, as exportações agrícolas dos Estados Unidos tiveram um aumento de 22\%, passando de \$6.7 bilhões em 1970 para \$44 bilhões em 1981. O volume exportado pelo país passou de 60 milhões de toneladas para 160 milhões de toneladas nesse período. O país se tornou o maior exportador de grãos no mercado mundial,

${ }^{53}$ Original em inglês: "Despite problems of perish-ability, agricultural commodities, once harvested, closely resemble other raw materials used as industrial inputs. Industrial processing operations often grew out of the trading activities of merchant capitals, as in the case of wheat and flour (...). That is, unable to subsume the rural production in toto, selected rural activities have become sectors of accumulation for different fractions of industrial capital". 
principalmente de trigo, milho e soja. $\mathrm{O}$ aumento das exportações ocorre principalmente devido à facilidade de acesso a crédito pelas empresas do agronegócio através da disponibilidade dos chamados 'petrodólares' e ao crescimento da demanda por grãos na União Soviética.

Dados do Ministério da Agricultura (USDA) de 1976 mostram que o Japão era o maior país importador de produtos agrícolas dos Estados Unidos, com um montante de \$3,3 bilhões de dólares anuais. O segundo era a União Soviética, com importações que somavam $\$ 1,86$ bilhões de dólares anuais. Outros grandes importadores eram Holanda (US\$1,76 bilhões), Alemanha Ocidental (US\$1,62 bilhões) e Canadá (US\$1,4 bilhões). O Brasil era o décimo terceiro país importador de grãos dos Estados Unidos e seu principal mercado na América Latina, com o equivalente a \$430 milhões de dólares anuais em importações agrícolas (RAWLINS, 1980, p. 12).

Mesmo com a chamada "crise do petróleo" nos anos 1970, a disponibilidade de combustível para o agronegócio nos Estados Unidos foi considerada prioridade. Em 1977 foram gastos $\$ 85$ bilhões de dólares em insumos petroquímicos no setor agrícola daquele país. Para efeito de comparação, estima-se que os gastos com salários de trabalhadores na agricultura somaram \$54 bilhões de dólares e com custos de empacotamento totalizaram \$15 bilhões de dólares (RAWLINS, 1980, p. 22-25).

Os insumos industriais utilizados na produção agrícola também exercem influência estratégica na pauta de exportações dos Estados Unidos. Algumas das principais commodities ligadas ao comércio internacional do agronegócio são petróleo e fertilizantes. Outras empresas relacionadas incluem setores de processamento, de vendas em atacado e de transporte e carregamento. Por exemplo, em 1990 a pauta de exportações agrícolas dos Estados Unidos foi de \$39,3 bilhões de dólares, enquanto os insumos industriais para tal produção somaram $\$ 62,8$ bilhões de dólares em valor agregado (ROSSON, 1994, p. 13).

Historicamente, a indústria automobilística esteve estreitamente ligada ao agronegócio. O início da mecanização da agricultura ocorre com a utilização de tratores de grande porte nos anos 1900 e se massifica com a produção de tratores menores que comportavam motores de automóveis, desenvolvidos por Henry Ford a partir de 1908. A produção de máquinas agrícolas manteve sua característica de monopólio até a atualidade, com apenas quatro empresas (Deere, International Harvester, Massey- 
Ferguson e Ford Motor Company) controlando 99\% do mercado mundial (RAWLINS, 1980, p. 61-62).

A concentração de capitais ocorre também na produção de insumos químicos. Segundo Rawlins (1980), este setor teve uma expansão de $172 \%$ entre 1960 e 1976 . As maiores empresas produtoras de pesticidas e fertilizantes têm ligação estreita com a indústria de petróleo e mineração. Entre os grupos que controlam a produção mundial de insumos químicos estão Ciba-Geigy, Monsanto, Elanco, Allied Chemicals, Phillips Petroleum Company, International Mineral and Chemical (IMC), Dow Chemical, e C.F. Industries (RAWLINS, 1980, 68-81).

De acordo com a análise de Rawlins (1980), a expansão do modo de produção conhecido como "agronegócio" é acompanhada por um processo de formação de monopólios na agricultura e "substituição de trabalho por capital", como mostra a seguinte citação:

Em 1900, o capital (incluindo a terra) contribuía com cerca de $25 \%$ no processo produtivo, e o trabalho com $75 \%$. Atualmente, cerca de $70 \%$ da produção de comida e fibras são atribuídos ao capital, e somente $30 \%$ ao trabalho. (...) Com o aumento do crédito, o pagamento de juros tem sido o custo agrícola que mais cresce. O índice de aumento dos juros dos agricultores aumentou de $32 \mathrm{em} 1956$ para 302 em 1970. (...) O Ministério da Agricultura estima que o total das dívidas agrícolas hoje seja maior do que $\$ 100$ bilhões, o que representa um aumento de mais de $300 \%$ desde 1960 (RAWLINS, 1980, p. 87) ${ }^{54}$.

O autor explica que o aumento da necessidade de crédito para cobrir os custos crescentes com capital constante na agricultura fez com que o governo dos Estados Unidos criasse o Sistema de Crédito Agrícola (Farm Credit System). Segundo sua avaliação: "todos os indicadores projetam uma maior necessidade de crédito agrícola no futuro, pois os agricultores continuarão a substituir trabalho por capital" (RAWLINS, 1980, p. 96).

\footnotetext{
${ }^{54}$ Original em inglês: "One of the major changes occurring in farming during recent years has been the substitution of capital for labor. Around 1900, capital (including land) contributed about 25 percent to the production process, and labor accounted for 75 percent. Currently, about 70 percent of the production of food and fiber is attributed to capital, while labor only accounts for 30 percent. (...) As a result of increasing borrowing, interest payments have been one of the fastest-growing costs of farming. The index of prices paid by farmers for interest rose from 32 in 1956 to 302 in 1970. (...) USDA reports estimate that total farm debt now exceeds $\$ 100$ billion, which represents an increase of more than 300 percent since 1960".
} 
Uma breve análise histórica da agricultura nos Estados Unidos nos ajuda a compreender a formação do sistema de produção que ficou conhecido como "agronegócio". Durante o século 19, foram introduzidas tecnologias mecânicas para aumentar a produtividade do trabalho na agricultura. No século 20, as principais mudanças ocorreram em relação a técnicas biológicas e químicas, introduzidas na agricultura principalmente a partir de 1930. Este processo de mudança nos padrões de produção, com a utilização de insumos industriais na agricultura, é intensificado principalmente na década de 1950 com o fim da Segunda Guerra Mundial (COCHRANE, p. 8, 1993).

A base científica aplicada à agricultura e posteriormente apropriada por empresas privadas foi desenvolvida inicialmente pelo Ministério da Agricultura (US Department of Agriculture - USDA) a partir de 1900. Cochrane (1993) identifica este processo como a base do que viria a se tornar o chamado "complexo do agronegócio" (“agribusiness complex"). Segundo o autor, o principal estímulo à industrialização da agricultura ocorre a partir de 1901, com a construção de motores à gasolina para tratores, o que permitiu sua utilização em grande escala. Em 1911, o número estimado de tratores em utilização nos Estados Unidos era de quatro mil. Este número se multiplicou nas décadas posteriores, passando para 264 mil em 1920 e para 920 mil em 1930 (COCHRANE, 1993, p. 108).

Neste período, cresce também o uso de insumos químicos entre agricultores nos Estados Unidos. A utilização de fertilizantes a base de nitrogênio teve um aumento estimado em 60\% entre 1910 e 1930. Entretanto, é importante observar que o aumento da produtividade na agricultura, tão propagado por defensores do agronegócio, não acompanhou o mesmo índice de crescimento dos insumos industriais. Foram registrados apenas 9\% de aumento da produção agrícola entre 1910 e 1920 e de $15 \%$ entre 1920 e 1930 (COCHRANE, 1993, p. 109-110).

Com a Primeira Guerra Mundial, verifica-se o aumento da demanda por exportação de grãos, principalmente dos Estados Unidos para a Europa. Este fato gerou forte aumento do preço dos alimentos, que praticamente dobrou entre 1916 e 1920. Aquele período foi marcado também pela especulação fundiária com imóveis rurais, que tiveram alta de $70 \%$ entre 1913 e 1920 . Porém, em meados da década de 1920, essa tendência se inverteu e houve uma queda de cerca de $50 \%$ nos preços dos alimentos. 
Ocorre então uma crise, praticamente generalizada, entre os agricultores nos Estados Unidos e muitos não puderam pagar suas dívidas imobiliárias. A crise no setor agrícola antecipou o colapso no mercado financeiro e a recessão na indústria, que culmina em 1929. Durante este período, conhecido como a Grande Depressão, a produtividade agrícola nos Estados Unidos permanece estável, mas a renda dos agricultores sofre uma queda de 50\% (COCHRANE, 1993, p. 100-101).

O setor agrícola volta a se expandir com a Segunda Guerra Mundial, quando há um aumento da demanda por alimentos e fibras, tanto no mercado externo quanto interno. Entre 1940 e 1946 houve um aumento de 138\% no preço dos produtos agrícolas. Este patamar se manteve no período pós-guerra através da intervenção estatal do governo estadunidense, que promoveu programas de garantia de preços aos agricultores para o mercado interno e gerou demanda externa adicional através de programas de "ajuda alimentar", principalmente em outros países afetados pela guerra (COCHRANE, 1993, p. 124).

O contexto de expansão econômica no período pós-guerra estimulou a massificação do uso de insumos químicos e da mecanização na agricultura, através da facilidade do acesso a crédito, subsídios e outros programas de assistência governamental. Em 1940, o número de tratores utilizados nos Estados Unidos era estimado em 1.6 milhões; passou para 3.4 milhões em 1950 e para 4.7 milhões em 1960. Em relação aos insumos químicos, houve um aumento do uso de fertilizantes à base de nitrogênio de 419 milhões de toneladas em 1940 para 7.459 milhões de toneladas em 1970; os insumos à base de potássio cresceram de 435 milhões de toneladas em 1940 para 4.035 milhões de toneladas em 1970 (COCHRANE, 1993, p. 125-126).

Segundo a visão de Cochrane (1993), este processo representou uma "revolução tecnológica" e foi acompanhado por uma mudança de modelo que o autor classificou como "revolução gerencial" (managerial revolution), caracterizada principalmente pela possibilidade de negociação de commodities agrícolas nos mercados de futuro. Porém, é importante notar que este tipo de mudança nos padrões de produção atingiu somente entre $10 \%$ e $15 \%$ do setor agrícola nos Estados Unidos. Este foi justamente o setor que passou a concentrar sua atuação no mercado internacional de commodities agrícolas (COCHRANE, 1993, p. 127-129). 
Entre 1933 e 1970, os agricultores nos Estados Unidos substituíram mais de 50\% dos insumos produzidos nas próprias unidades agrícolas por insumos industriais. Houve um aumento de $212 \%$ no uso de máquinas e de $1800 \%$ no uso de insumos químicos. No mesmo período, se registra uma diminuição de mais de $70 \%$ na mão de obra agrícola. Este é basicamente o processo caracterizado como a formação do agribusiness ou farming business (COCHRANE, 1993, p. 129-132).

Porém, a produtividade das principais lavouras comerciais não cresceu na mesma proporção. Dados do Ministério da Agricultura (Department of Agriculture) mostram que entre 1870 e 1940 a produção agrícola se mantém em patamares semelhantes: a produtividade de trigo por acre passa de $12.7 \mathrm{em} 1870$ para $15.7 \mathrm{em}$ 1950; a de milho passa de 26.1 em 1870 para 37.8 em 1950; e a de algodão aumenta de 174.2 em 1870 para 273.4 em 1950. Um novo aumento de produtividade é verificado após 1950, mas parece se estabilizar em um determinado patamar em 1970, quando esses números são: 31.8 para o trigo, 80.8 para o milho e 436.7 para o algodão (COCHRANE, p. 128).

\section{Crise estrutural de superacumulacão}

Com a permanência da crise estrutural de superacumulação que ocorre no período pós-guerra, o setor agrícola dos Estados Unidos dependia de subsídios estatais e da manutenção de programas para facilitar as exportações de grãos. Na década de 1990, mais de um terço da produção era destinado à exportação. Em 1992, o volume de grãos exportados dos Estados Unidos para outros países chegou a \$42 bilhões de dólares. A comercialização no mercado externo de produtos industrializados do agronegócio, com maior valor agregado, também tinha um peso significativo na balança comercial. $O$ volume destas exportações passou de \$28 bilhões de dólares nos anos 1960 para \$240 bilhões de dólares na década de 1990. O aumento das exportações de comida processada acaba por gerar uma maior demanda por importações de matérias primas agrícolas, que passaram de \$5.6 bilhões de dólares em 1970 para \$22,6 bilhões de dólares em 1990. Porém, este tipo de matéria prima necessária para suprir a indústria de alimentos processados nos Estados Unidos seria considerado como importação "não competitiva", já que funcionaria para complementar aquilo que não era produzido no país (ROSSON, 1994, p. 6-7). 
Para entendermos o processo que levou à crise de superacumulação nos Estados Unidos, partimos da análise do período de depressão econômica na década de 1930, quando se iniciou a chamada "industrialização" da agricultura que, por sua vez, veio a exercer um papel central na nova onda de acumulação, que culminou no período pósguerra.

Os alimentos enlatados, que inicialmente cumpriram o papel de alimentar as tropas militares durante a Segunda Guerra Mundial, tiveram um peso fundamental na cadeia do agronegócio. Outros tipos de alimentos processados que se massificaram a partir dos anos 1960 foram os congelados, desidratados e as misturas em pó. Para garantir a distribuição em massa desses produtos, são formadas grandes cadeias de vendas em atacado e varejo, como os supermercados. Este processo é denominado por mentores do agronegócio como "integração horizontal", que significaria a formação de monopólios através de fusões e aquisições de empresas que passam a exercer controle sobre um ramo específico de negócio. Já a chamada "integração vertical" caracterizaria o controle de vários setores do agronegócio por uma mesma empresa. Segundo os ideólogos do agronegócio, estes tipos de "integração" trariam diversas "vantagens" como, por exemplo, "garantir uma economia de escala, poder de acesso a maiores linhas de crédito, aproveitamento de gerentes, facilidade de entrada em novos mercados, proteção através de mercados amplos geograficamente, e maior efetividade na concorrência" (HAMPE; WITTENBERG; EDDS, 1980, p. 8-11).

Apesar de este tipo de discurso conter uma visão positiva sobre o desenrolar do processo de formação de monopólios no agronegócio, que marcou a chamada "industrialização" da agricultura, na verdade expressa a própria crise de superacumulação do setor, caracterizada pelo aumento do capital constante em relação ao trabalho vivo a ser explorado. A citação acima revela a necessidade de massificação da produção, da eliminação da concorrência representada por empresas menos produtivas e, principalmente, da necessidade de aumentar ativos como estratégia para acessar grande quantidade de crédito ou subsídio estatal.

O processo de acumulação de capital no setor agrícola estadunidense, gerado a partir da Segunda Guerra Mundial, foi precedido por uma série de medidas governamentais que tiveram início na década de 1930. Tais medidas incluíram garantias de preço para commodities agrícolas; controle do volume produzido através de 
incentivos econômicos para que os agricultores diminuíssem sua produção (através de leis como The Soil Conservation and Domestic Allotment Act of 1936), promovessem a conservação do solo e transformassem certas áreas em reversas florestais; através da compra governamental de produtos perecíveis; do mecanismo de dumping da produção excedente no mercado externo e de programas governamentais para estimular o mercado interno (HAMPE; WITTENBERG; EDDS, 1980, p. 61).

Em 1938, o Congresso dos Estados Unidos aprovou um pacote agrícola chamado Agricultural Adjustment Act, através do qual o governo poderia dar continuidade à política de financiamento aos agricultores que substituíssem os monocultivos intensivos por meios de conservação do solo. Este programa também incluía garantia de preços para determinados produtos agrícolas, estabelecia cotas de mercado para evitar a superprodução de determinadas commodities e aumentava o volume de recursos para compras governamentais de alimentos, que eram distribuídos para escolas e para famílias de baixa renda. Apesar de todas estas medidas, a superprodução agrícola persistiu principalmente nas lavouras de trigo. Em 1954, a produção de trigo foi de 983 milhões de sacas, enquanto em 1960 foi de 1,36 bilhões de sacas, mesmo com a redução de 16 milhões de acres cultivados. O Congresso estadunidense decide então expandir medidas para facilitar as exportações de grãos, autorizando o pagamento em moeda dos próprios países importadores e determinando que este recurso fosse utilizado para o "desenvolvimento econômico" local. Esta política foi complementada por programas de incentivo ao mercado interno de alimentos. Por exemplo, em 1961 o governo dos Estados Unidos inicia um amplo programa de "ajuda alimentar" para famílias de baixa renda, conhecido até hoje como Food Stamp Program, que poderia ser descrito como um "vale alimentação" governamental (HAMPE; WITTENBERG; EDDS, 1980 p. 74-77).

Além de diversas medidas governamentais de apoio ao agronegócio nos Estados Unidos, o acesso a crédito triplicou entre 1940 e 1962. Este aumento foi acompanhado pela massificação da utilização de insumos químicos. Durante o mesmo período, o uso de fertilizantes químicos duplicou, assim como a prática de fumigação aérea. Diversos modelos de máquinas agrícolas passaram a ser utilizados na preparação do solo e na colheita, tanto em grandes quanto em pequenas plantações. Este período foi marcado pela padronização dos cultivos e pela maior concentração fundiária, porém somente em 
termos relativos, já que as propriedades familiares continuaram a representar a maioria das fazendas (HAMPE; WITTENBERG; EDDS, 1980, p. 65-66).

De acordo com dados do Censo Agrícola do Ministério da Agricultura dos estados Unidos (USDA), desde 1930 ocorreu uma tendência de diminuição do número de fazendas e, ao mesmo tempo, um aumento de seu tamanho. Em 1960 eram 3,9 milhões de propriedades e em 1976 este número passou para 2,8 milhões, o que significa um decréscimo de 30\%. Porém, esta mesma percentagem foi verificada no sentido inverso em relação à extensão média das fazendas, que era de 297 acres em 1960 e passou para 389 acres em 1976 (RAWLINS, 1980, p. 37).

Por outro lado, o setor de distribuição e comercialização do agronegócio tomou uma característica cada vez mais monopolista, com a expansão, por exemplo, das redes de supermercados. Entre 1950 e 1960, o número de supermercados dobrou e suas vendas quadriplicaram, representando $70 \%$ do mercado de varejo nos Estados Unidos. Este processo foi acompanhado pela padronização dos alimentos e pela influência exercida por agências de publicidade na opinião pública, com o papel de disseminar determinadas marcas de produtos processados. Os supermercados cumpriam ainda a função de "cenário" para a exibição desse tipo de propaganda, além de combinar a venda de alimentos com outros tipos de produtos, como de limpeza, higiene, brinquedos, revistas e remédios (HAMPE; WITTENBERG; EDDS, 1980, p. 328).

Tal tendência de massificação e padronização da produção de alimentos se intensifica em um período de crise econômica mundial, que tem como alguns fenômenos mais aparentes o aumento no preço mundial de commodities, principalmente o petróleo, mas também produtos agrícolas. No início dos anos 1970, esta crise de superprodução nos Estados Unidos é descrita pelos próprios ideólogos do agronegócio como, "O velho problema agrícola, abundância, continua a ser uma praga na agricultura americana, escapando de todos os remédios utilizados durante todos esses anos, desde a Segunda Guerra Mundial" (HAMPE; WITTENBERG; EDDS, 1980 p. 79$)^{55}$.

A partir de 1980, em pleno período de disseminação do discurso neoliberal, o apoio estatal para a agricultura estadunidense atingiu seu maior nível em décadas. Em

\footnotetext{
${ }^{55}$ Original em inglês: "that old farm problem, abundance, continued to be a plague on American agriculture, having escaped all the remedies that have been tried over the many years since World War II."
} 
meados dos anos 1980, a recessão mundial causou a diminuição das exportações agrícolas do país, que não passaram de $\$ 26$ bilhões em 1986. A resposta do governo foi adotar um novo conjunto de leis, conhecido como Food Security Act, com o propósito de expandir subsídios e programas de apoio às exportações. Além desta medida, o governo estadunidense mantém uma política cambial favorável às suas exportações e direciona sua política externa para intensas negociações de tratados de "liberalização comercial", entre eles o GATT (General Agreement on Tariffs and Trade) e NAFTA (North American Free Trade Agreement) (ROSSON, 1994, p. 3-5).

Na década de 1980, a conjuntura de recessão econômica mundial torna mais difícil o convencimento do discurso sobre a "eficiência" do agronegócio. Naquele período, o próprio idealizador deste sistema de produção, Ray Goldberg, reconhece a instabilidade gerada pelas dívidas do setor nos Estados Unidos e a impossibilidade de o agronegócio se manter economicamente sem as diversas formas de intervenção do Estado, como crédito subsidiado e política cambial. Ele afirma que:

Em 1984 o custo dos juros por acre produzido com milho nos Estados Unidos era quase equivalente ao custo com fertilizante por acre, e dependendo das condições de mercado dentro do sistema do agronegócio, muitos produtores comerciais foram pegos nessa relação custo-preço, com suas operações quase não se pagando. As políticas de preço do governo tornaram-se mais necessárias, já que os produtores comerciais e empresas de insumos, assim como os processadores e distribuidores de produtos subsidiados com valor agregado, viram seus lucros e sua própria sobrevivência em risco. Entre todos os fatores, o câmbio do dólar parece ser o mais importante, influindo na competitividade dos Estados Unidos em um mercado global de commodities com preços flutuantes (GOLDBERG, 1985, p. 17) ${ }^{56}$.

A característica de priorizar subsídios para setores ligados ao agronegócio, em detrimento da pequena agricultura, faz parte da política estatal tanto nos Estados Unidos como em outros países. Dados de 2002 mostram que nos Estados Unidos 10\% dos agricultores recebiam dois terços dos subsídios. Na Inglaterra, $80 \%$ dos subsídios eram

\footnotetext{
${ }^{56}$ Original em inglês: "By 1984 interest cost per acre for producing corn in the United States was fast approaching fertilizer cost per acre, and depending on the terms of trade within the agribusiness system, many commercial producers have been caught in a cost-price squeeze with a high break-even for their farming operations. Government price policies become even more critical, as the commercial producer and farm supplier, as well as the processor and distributor of subsidized export value-added products, have not only their profitability at stake but their very survival. Of all the factors noted so far, the dollar exchange rate would seem to be one of the most important affecting U.S. competitiveness in a price-sensitive agricultural global commodity market".
} 
concedidos a $20 \%$ das maiores empresas agrícolas. Estes dados mostram que o agronegócio só é capaz de sobreviver economicamente através do acesso a subsídios estatais. Um dos fatores que demonstra tal necessidade pode ser avaliado através da análise do preço das commodities agrícolas, que é geralmente menor do que o custo de produção. O aumento do nível de produtividade, através da mecanização e do uso de insumos petroquímicos na agricultura, não é capaz de cobrir os altos custos de produção. Para se adaptar ao processo de mecanização, muitos agricultores passaram a priorizar os monocultivos, deixando de realizar práticas de diversificação de lavouras que contribuem com a manutenção da fertilidade natural do solo. Como consequência, a perda de fertilidade do solo acaba por afetar os níveis de produtividade e a exigir maiores gastos com insumos químicos, o que gera maior endividamento e a crescente necessidade de acessar subsídios estatais. Por sua vez, a necessidade de apoio estatal vai determinar o aumento da concentração de capitais (HODGE; MERRIFIELD; GORELICK, 2002, p. 5-7).

A concentração de mercado e o processo de formação de monopólios entre empresas do agronegócio teriam como função central garantir o acesso dessas empresas a recursos estatais. Como analisamos anteriormente, a concentração de ativos de uma empresa é utilizada como estratégia de barganha nos jogos de poder sobre as diversas esferas de Estado. Portanto, ao invés do discurso comumente propagado de "eficiência" ou "alta produtividade" do agronegócio, com conotação ufanista, nossa pesquisa demonstra uma situação de crise estrutural do setor. Esta análise pode ser confirmada através da avaliação de diversos autores, como na seguinte afirmação: "Esses enormes complexos industriais se expandem não porque são mais produtivos (eles são, de fato, muito menos produtivos), mas porque são sistematicamente apoiados por políticas governamentais" (HODGE; MERRIFIELD; GORELICK, 2002, p.8) ${ }^{57}$.

\section{A revolucão vende como base ideológica do agronegócio}

No mesmo período em que o conceito de agribusiness passa a ser difundido, a partir da década de 1950, é possível observar um conjunto de medidas impulsionadas por governos e instituições privadas que intensificaram a apropriação da renda da terra

\footnotetext{
${ }^{57}$ Original em inglês: "These huge industrial-style operations are thriving not because they are more productive (they are, in fact, far less productive), but because they are systematically supported by government policies".
} 
por setores industriais em todo o mundo. Em seu livro The Violence of the Green Revolution (1991), Vandana Shiva descreve tal processo e avalia que este pacote tecnológico teve uma função econômica, política e ideológica, ao ser vendido sob o nome de revolução verde.

Shiva (1991) explica que o conceito de "revolução verde" foi criado a partir da ideia de uma suposta neutralidade científica. A noção da ciência como desprovida de conteúdo político, ou seja, acima do "bem e do mal", significa que não deve ser questionada. Segundo a autora: "Apesar de a ciência ser produto de forças sociais e de seu conteúdo ser determinado por setores que podem mobilizar a produção científica, a atividade científica contemporânea recebeu a posição privilegiada de neutralidade social e política" (SHIVA, 1991, p. 21). ${ }^{58}$

Para implantar a série de políticas conhecida como "revolução verde" em nível mundial seria necessário criar uma imagem perante a opinião pública de que este modo de produção provinha de avanços tecnológicos reconhecidos de maneira universal ${ }^{59}$. Tal ideia vem acompanhada da propaganda sobre as supostas vantagens desta política agrícola para o aumento da produtividade, no sentido de gerar abundância de alimentos. Alguns dos elementos centrais para justificar este modo de produção na agricultura são a uniformidade e extensão dos cultivos, o uso de máquinas e insumos químicos, além da intensificação do uso de água e energia no processo produtivo. Ao analisar a difusão da "revolução verde” na África, Samir Amin (1977) explica que:

É rico o arsenal de meios administrativos posto em funcionamento para obrigar o camponês a produzir aquilo que querem que produza, da maneira como querem: há, desde uma ordem pura e simples, à velada (a da imposição pelo dinheiro, quando o ameaçam de lhe comprar um só produto) ou à obrigação decorrente da ação dita de promoção ou modernização dos serviços do 'quadro rural', (divulgação acompanhada de vendas de material praticamente forçadas: arados, semeadores, enxadas, inseticidas, adubos). (...) Aí está o segredo do atraso da 'revolução verde' na África tropical. Esta rentabilidade é obtida ao preço da pilhagem do solo, do desflorestamento, de formações de desertos (...). A rentabilidade é obtida, também, ao preço de uma remuneração, inferior ao

\footnotetext{
${ }^{58}$ Original em inglês: "While science itself is a product of social forces, and has a social agenda determined by those who can mobilize scientific production, in contemporary times scientific activity has been assigned a privileged epistemological position of being socially and politically neutral".

${ }^{59}$ Em relação ao pensamento geográfico, Oliveira (2004, p. 31) explica que a base doutrinária da objetividade ou neutralidade se constituiu a partir de "uma ideologia conservadora identificada com a ordem industrial/burguesa estabelecida", que representa a ideia de "uma ciência axiologicamente neutra”.
} 
valor da força de trabalho, que acaba inutilizada - como demonstram o alto índice de mortalidade, a desnutrição e a fome, devidas ao retrocesso das produções agrícolas, êxodo rural, etc. (AMIN, 1977, p. 37-38).

É possível identificar as origens da "revolução verde" a partir do período de Depressão Econômica, na década de 1930, quando o governo dos Estados Unidos adotou medidas para restringir a importação de alimentos e proteger a agricultura local. Esta política incluía subsídios, tanto para a produção de alimentos quanto para a garantia de preços, o que gerou produtos excedentes, principalmente grãos. Com isso, o governo passou a financiar a exportação e a utilizar o discurso de "ajuda alimentar" para inundar o mercado mundial de grãos, gerando dependência e destruição da agricultura local em muitos países. Além desta prática no mercado de grãos, conhecida como dumping, empresas do agronegócio estadunidense intensificaram a exportação de capitais. Isto significou a implantação de empresas subsidiárias, em diversos países, para produzir insumos contidos no chamado "pacote tecnológico" da "revolução verde". A partir dos anos 1970, empresas transnacionais do agronegócio também passam a se beneficiar de políticas de desregulamentação cambial e da predominância do capital financeiro na agricultura (McMICHAEL, 2000, p. 130-131).

Segundo Welch (2005), a "revolução verde" se constituiu como estratégia de internacionalização do modelo de agronegócio, que abrange a mecanização das fazendas e a intensificação do uso de agrotóxicos, além da liberalização comercial patrocinada pelo Estado. As pesquisas que deram origem a pesticidas e máquinas agrícolas foram iniciadas durante a Segunda Guerra Mundial, com o objetivo de produzir armas químicas e tanques de guerra.

No período pós-guerra, esta tecnologia foi adaptada para compor o setor denominado de agribusiness, que prometia promover prosperidade e paz. Shiva (1991) lembra que, em 1970, Norman Borlaug recebeu o Prêmio Nobel da Paz por ter desenvolvido as chamadas "sementes milagrosas". O cientista americano foi considerado como o "pai" da revolução verde. O significado do prêmio teve como consequência gerar a percepção de que, "A ciência foi premiada por ter uma habilidade mágica de resolver problemas de escassez material e violência” (SHIVA, 1991, p. 19) ${ }^{60}$.

\footnotetext{
${ }^{60}$ Original em inglês: "Science was awarded for having a magical ability to solve problems of material scarcity and violence".
} 
Para justificar a difusão de novas tecnologias na agricultura seria necessário gerar uma demanda ou dependência de insumos industriais por parte dos agricultores e, ao mesmo tempo, disseminar o medo da escassez de alimentos na opinião pública. Shiva (1991) explica que, no período anterior à adoção deste modelo, a produtividade agrícola na Índia era mais abundante e diversificada. A escassez de alimentos se agrava na medida em que prevalecem os monocultivos e a dependência de insumos industriais produzidos por empresas estrangeiras, causando redução da fertilidade do solo e da diversidade genética.

Segundo Shiva (1991) o modelo conhecido como "revolução verde" foi impulsionado inicialmente por duas instituições privadas, as fundações Ford e Rockfeller, em colaboração com agências do governo estadunidense, principalmente USAID, e com o Banco Mundial. A partir de 1952, as fundações Ford e Rockfeller passaram a financiar e promover pesquisas e treinamentos com base neste pacote tecnológico em vários países. Outra estratégia de difusão desta política foi a concessão de bolsas de estudo para pesquisadores estrangeiros estudarem em instituições norteamericanas.

Em 1958, o Instituto Indiano de Pesquisa Agrícola (Indian Agriculture Research Institute) foi reformulado e o diretor de pesquisa da fundação Rockfeller assumiu o comando da instituição. Em 1960, a fundação Ford cria o Programa de Desenvolvimento da Agricultura Intensiva (Intensive Agricultural Development Programme - IADP) na Índia, sob o argumento da necessidade de modernização agrícola. De acordo com os representantes da fundação Ford, os recursos naturais do país estariam sendo "subutilizados" e deveriam ser aproveitados de maneira "eficiente" (SHIVA, 1991, p. 29-35).

A partir da criação de uma demanda entre agricultores em diversos países, através da introdução deste "pacote tecnológico", instituições como as fundações Rockfeller e Ford, USAID e Banco Mundial abriram linhas especiais de financiamento para a compra de insumos químicos, incluindo fertilizantes, pesticidas e sementes, que passaram a ser importados por agricultores indianos. Ao mesmo tempo, essas agências promoviam políticas de "liberalização" comercial no país (SHIVA, 1991, p. 30).

Na América Latina, essa política teve início no México onde, desde 1945, a fundação Rockfeller atuava junto ao Ministério da Agricultura. Em 1961 a fundação 
Rockfeller cria o Centro Internacional de Melhoramento de Trigo e Milho (CIMMYT), que passa a monopolizar pesquisas com sementes. A padronização das sementes seria crucial para o sucesso do novo "pacote tecnológico", porque as espécies nativas não necessitavam do uso intensivo de insumos químicos. A pesquisa com as chamadas "sementes milagrosas" teve início com a contratação de Norman Borlaug, que havia trabalhado em um laboratório da Dupont durante a Segunda Guerra Mundial, pela fundação Rockfeller no México (SHIVA, 1991, p. 33-37).

Ao longo dos anos 1960 as fundações Ford e Rockfeller expandiram sua política em nível internacional, através da criação do Instituto Internacional de Pesquisa do Arroz (International Rice Research Institute ) nas Filipinas, do Centro Internacional de Agricultura Tropical (CIAT) na Colômbia e do Instituto Internacional de Agricultura Tropical (IITA) na Nigéria. Em 1971, estes institutos se articularam para formar o Grupo Consultivo Internacional de Pesquisa Agrícola (Consultative Group on International Agricultural Research - CGIAR) sob a coordenação do presidente do Banco Mundial na época, Robert McNamara (SHIVA, 1991, p. 43).

As principais fontes de financiamento deste grupo vinham das fundações Ford e Rockfeller e da USAID. Posteriormente, outros institutos de pesquisa com o mesmo propósito se incorporaram a esta articulação, incluindo o Centro Internacional da Batata (CIP) no Peru, West African Rice Development Association (WARDA) na Libéria, o Laboratório Internacional de Pesquisa em Doenças Animais (ILRAD) no Quênia, International Board for Plant Genetic Resources na Itália, International Livestock Center for Africa na Etiópia, International Food Policy Research Institute nos Estados Unidos, International Center for Agricultural Research in the Dry Areas na Síria e International Service for National Agriculture Research na Holanda. O Brasil fazia parte do grupo, que passou a receber recursos de governos, agências das Nações Unidas e empresas como Bayer, Chevron, Dow Chemical, Esso Engineering, Hoeschst, Monsanto, Shell, entre outras. Como veremos mais adiante, esta lista de empresas é semelhante à composição do setor que se caracterizou como complexo agroindustrial no Brasil e revela a conexão deste processo com a promoção da chamada revolução verde.

A influência do grupo Rockefeller no Brasil está documentada em uma carta de Alysson Paulinelli, Ministro da Agricultura durante o regime de Ernesto Geisel entre 1974 e 1979, que também foi presidente da Confederação Nacional da Agricultura 
(CNA). Na carta, endereçada a Rodman C. Rockefeller, o então ministro Paulinelli agradece o recebimento de cópia de uma palestra proferida por Rockefeller durante uma reunião do Agribusiness Council em 1975. A carta de Paulinelli diz:

Reitero meus agradecimentos, tanto pela gentileza de prontamente enviá-la, como por suas palavras de grande incentivo aos investidores para que tragam ao Brasil o benefício de sua tecnologia e do seu capital, proporcionando um maior desenvolvimento à agricultura brasileira ${ }^{61}$.

Kloppenburg (1988) descreve os impactos da "revolução verde" em nível internacional e também identifica as fundações Rockefeller e Ford como promotoras desta política. $\mathrm{O}$ autor revela que estas fundações financiaram os centros internacionais de pesquisa agrícola (International Agricultural Research Centers - IARCs) durante as décadas de 1960 e 1970. O modelo de produção difundido por estas instituições gerou a expansão de monocultivos, a especialização da produção, a migração de trabalhadores e camponeses, causando uma mudança significativa na estrutura fundiária e na forma de uso da terra em vários países.

Outro aspecto que caracterizou este modelo agrícola foi sua dependência de maquinários e insumos químicos, o que causou erosão genética, deterioração dos solos e especulação com o preço da terra. Em seu estudo, Kloppenburg revela que este processo tem início com a produção de sementes, que adquirem o papel de "veículos de acumulação de capital", ao contrário da ideia comumente difundida que "atribui uma lógica tecnológica imanente à descoberta científica" (KLOPPENBURG, 1988, p. 8). O autor compara este tipo de visão à "linearidade bíblica", atribuída ao conhecimento científico, que ignora o contexto social mais amplo onde se insere a ciência no modo capitalista de produção.

Assim como em outros setores do agronegócio, as empresas produtoras de sementes passaram por processos de fusões e aquisições nos anos 1970, quando o mercado mundial veio a ser controlado principalmente por transnacionais petroquímicas e farmacêuticas como Monsanto, Pfizer, Shell e ARCO (KLOPPENBURG, 1988, p. 16). Kloppenburg argumenta que o desenvolvimento tecnológico e científico deve ser

${ }^{61}$ Alysson Paulinelli (Ministro de Agricultura, 1974-1979) para Rodman C Rockefeller, 8 março de 1976, pasta 98, caixa 7, Série "Projects and Proposals", Coleção "International Basic Economy Corporation" Rockefeller Foundation Archives, Rockefeller Archive Center, Sleepy Hollow, New York. Agradeço a Clifford Andrew Welch por me passar cópia deste documento. 
analisado no âmbito da economia política, considerando-se a universalização da formamercadoria, a divisão internacional do trabalho e a apropriação de conhecimento genético em escala mundial, que ocorre na medida em que se expande o processo de acumulação primitiva com a separação dos trabalhadores de seus meios de produção. Para o autor "a pesquisa agrícola pode ser entendida como um meio importante de eliminar barreiras para a penetração do capital na agricultura" (KLOPPENBURG, 1988, p. 10).

Nesse sentido, as sementes adquirem um duplo papel, como meios de produção e como mercadorias na agricultura capitalista, já que podem ser comparadas ao "mito da Fênix, porque reemergem das cinzas no processo produtivo em que são consumidas" (KLOPPENBURG, 1988, p. 10). Por essa razão, a produção de sementes híbridas, que não possuem essa característica de reprodução natural, se constitui como fator determinante no sentido de "abrir novas fronteiras para a acumulação do capital", inclusive através de mecanismos jurídicos de propriedade intelectual (KLOPPENBURG, 1988, p. 11).

Atualmente, tal política agrícola, baseada nos moldes da "revolução verde", continua a ser disseminada no Brasil através da promoção do conceito de agronegócio. Este conceito também está relacionado à ideia de "progresso" e "evolução tecnológica", que serve para definir um modo de produção baseado na agricultura extensiva, associada ao monocultivo e dependente tanto de insumos químicos e industriais quanto de grande quantidade de terra e água.

Dados sobre a perda na fertilidade do solo em consequência do modelo agrícola dependente de insumos químicos geralmente são omitidos das estatísticas oficiais. Porém, a crescente dependência de fertilizantes à base de nitrogênio evidencia o desgaste causado aos nutrientes naturais, o que diminui a porosidade dos solos e a consequente disponibilidade de oxigênio. O sistema do agronegócio demanda, portanto, grande quantidade de energia fóssil, o que gera vulnerabilidade econômica em uma conjuntura de disputas geopolíticas por petróleo e gás natural, além da instabilidade causada pelo papel que estas commodities exercem no movimento especulativo do mercado financeiro. Para avaliar de forma mais precisa os custos e a suposta "eficiência" deste modelo agrícola, seria necessário ainda considerar seus impactos poluentes em fontes de água e na qualidade do ar (PERELMAN, 1979). 
A opção governamental de priorizar o financiamento da grande exploração agrícola ignora estudos que comprovam maior produtividade da pequena agricultura, levando em consideração sua menor dependência econômica de insumos industriais e custos mais baixos de distribuição em mercados locais. É possível constatar, portanto, que este tipo de opção não teria necessariamente uma base científica ou econômica, como é frequentemente propagado. Faria mais sentido admitir que todo o esquema de construção do agronegócio, ou do "pacote" tecnológico conhecido como "revolução verde", faz parte de um programa político para subvencionar grandes empresas que passam a atuar na agricultura, principalmente a partir da crise de superacumulação de capital no período pós-guerra.

Por exemplo, durante o período de promoção da chamada "revolução verde" e principalmente na década de 1970, a indústria de fertilizantes estava entre as quatro maiores do mundo, atrás somente dos setores de petróleo, aço e cimento. Segundo declaração do Economista Chefe da Agência do Departamento de Estado dos EUA para o Desenvolvimento Internacional, John W. Mellor, "no geral, a Revolução Verde é principalmente um esquema de fertilizantes" (PERELMAN, 1979, p. 169-171). Dados do Banco Mundial na época mostram que pelo menos metade da exportação de fertilizantes dos Estados Unidos para países do Terceiro Mundo era subsidiada pelo governo estadunidense. Tal política tornou-se essencial para a manutenção do controle sobre o mercado mundial de grãos e para garantir a dependência de outros países através de programas de "ajuda alimentar".

Alguns autores explicam as razões que levaram à disseminação deste modo de produção agrícola através da necessidade de grandes empresas ampliarem o mercado consumidor de produtos e insumos agroindustriais, além de compor uma estratégia para conter disputas políticas por terra e subjulgar a classe trabalhadora a uma situação mais vulnerável de exploração (PERELMAN, 1979, p. 146). È certo que, com o aumento dos custos de produção, a industrialização da agricultura gerou, por um lado, maior dependência dos agricultores e da força de trabalho em geral, tanto rural quanto urbana. Por outro lado, causou aumento do preço da terra, já que este cálculo necessariamente leva em conta os custos de produção com insumos industriais.

Apesar de realmente constatarmos este tipo de impacto gerado pela disseminação do agronegócio em âmbito internacional, o centro de nossa análise deve 
partir do processo produtivo ou da relação capital-trabalho na agricultura. Como esclarecemos anteriormente, entendemos que a chamada "industrialização" da agricultura faz parte de um movimento crítico próprio do modo capitalista de produção, que, nos termos de Marx, gera um desequilíbrio na composição orgânica do capital, ou seja, na relação entre trabalho "morto" acumulado (capital constante) e trabalho vivo representado pela exploração de mais-valia (capital variável). 


\section{Capítulo 4 - O conceito de Complexo Agroindustrial}

\section{$\underline{\text { A influência positivista na análise de políticas agrárias }}$}

Distintas correntes no marxismo analisam a questão agrária, porém com diferenças substanciais em relação à interpretação das ideias de Marx. Em seu livro $A$ Questão Agrária lançado em 1899 Kautsky expressa uma visão que pode ser considerada positivista ou etapista já que, ao estudar a passagem do feudalismo para o capitalismo, admite a permanência da parcelarização da terra em alguns contextos, mas principalmente centra sua tese nas vantagens da grande propriedade para a organização do trabalho, para o acesso à matérias-primas, máquinas e avanço tecnológico, afirmando que, "Foram criadas, assim, as condições técnicas e científicas da agricultura racional e moderna, a qual surgiu com o emprego de máquinas e deu-lhe, pois, a superioridade da grande exploração capitalista sobre a pequena exploração camponesa" (KAUTSKY, 1968, p. 317).

Löwy (2009) define o pensamento positivista que, tanto entre certas correntes do marxismo como a social-democracia, quanto nos meios científicos empiristas, assume a mesma característica: "Como os positivistas, Kautsky tendia a assimilar natureza e sociedade, pretendendo que as leis da sociedade podiam ser definidas como leis naturais" (LÖWY, 2009, p. 135). Samir Amin (1977) expõe o mesmo tipo de observação sobre a defesa de Kautsky em relação à agricultura extensiva, quando afirma que: "A social-democracia formula a lei deste desenvolvimento em termos simples: a concorrência deve eliminar progressivamente os camponeses, em favor dos grandes capitalistas agrários que dispunham de capitais necessários à utilização da mecanização" (AMIN, 1977, p. 25).

Apesar de manter sua opinião sobre as "vantagens" da grande exploração agrícola, é preciso mencionar algumas nuances no pensamento de Kautsky, que chegou a reconhecer o papel da agricultura camponesa, como constatamos na seguinte citação:

(...) a teoria marxista do sistema de produção capitalista não consiste simplesmente em reduzir a evolução deste à fórmula - Desaparecimento da pequena exploração diante da grande - que, uma vez decorada, nos pusesse por assim dizer no bolso a chave do edifício da economia moderna. Se se deseja estudar a questão agrária segundo o método de Marx, não se deve equacionar apenas o problema de saber se a pequena exploração tem ou não futuro na agricultura. Deve-se, ao contrário, pesquisar todas as transformações experimentadas por esta última no decurso do regime de produção capitalista. Deve-se pesquisar se e como o capital se apodera da agricultura, 
revolucionando-a, subvertendo antigas formas de produção e de propriedade, criando a necessidade de novas formas" (KAUTSKY, 1968, p. 24).

Kautsky defendia a tese de que a agricultura extensiva, baseada em grandes unidades produtivas de propriedade do Estado, possibilitaria liquidar a propriedade privada da terra. Segundo o autor, os camponeses representariam uma classe em transição entre as duas classes consideradas fundamentais no capitalismo - proletários e burguesia. Tal perspectiva tinha como premissa o momento em que o modo capitalista de produção se tornara dominante, como descreve a seguir:

É o antagonismo da classe dos capitalistas e do proletariado assalariado que move o nosso século e lhe dá a sua fisionomia. Mas o modo de produção capitalista não constitui a única forma de produção existente na sociedade de nossos dias. Ao lado dele se encontram ainda restos de modos de produção précapitalistas que se mantiveram até hoje (KAUTSKY, 1968 p. 21).

De acordo com Hobsbawm (1984), a posição de Kautsky não considerou o papel significativo da propriedade camponesa naquele período, já que a grande empresa agrícola não estava difundida na maioria dos países europeus. Hobsbawm observou que a situação dos camponeses na Europa era bastante diversa. Na França e Alemanha a maioria da produção era realizada em propriedades camponesas. Na Prússia prevaleciam médios proprietários e, em algumas regiões da Espanha, ainda se encontravam latifúndios semifeudais. Somente na Inglaterra se desenvolvia a produção capitalista em grande escala. (HOBSBAWM, 1984, p 154).

Samir Amin (1977) considera tal diferenciação entre os tipos de organização do trabalho agrícola em diferentes países, mas argumenta que, mesmo nos casos em que prevalece a agricultura camponesa, a totalidade do modo capitalista de produção deve nos remeter sempre à chave para entender a renda da terra, ou seja, à mais-valia:

Podemos, a grosso modo, distinguir a forma inglesa, onde a burguesia alia-se à grande propriedade capitalista da terra (os gentlemen farmers) até fundirem-se numa única classe, e a reforma francesa, onde a burguesia alia-se aos camponeses e opera uma reforma agrária radical, que assegura uma nova classe rural do tipo koulak. Seja qual for a forma desta aliança, é paga pela extração de uma fração da mais-valia em benefício da propriedade fundiária. Pode-se agora falar de renda capitalista em sentido pleno, já que é obtida da mais-valia (AMIN, 1977, p. 24).

Em sua obra História do Marxismo (1984) Hobsbawm traça um panorama sobre as divergências envolvendo correntes do marxismo em relação ao programa agrário socialista. Os principais debates incluíam opiniões distintas sobre a "eficácia" da concentração do capital agrícola em relação à produção camponesa. Cabe lembrar que 
essa discussão estava pautada por interpretações opostas sobre a suposta sucessão necessária dos modos de produção, como caminho teórico para entender o processo histórico.

No contexto europeu, ocorrera o processo de transição do feudalismo para o capitalismo. Porém, a adoção desta tese em outros continentes gerou correntes diversas de interpretação sobre a questão agrária, apesar de Marx ter esclarecido que sua análise sobre a acumulação primitiva partiu da situação particular da Inglaterra no período de transição do feudalismo para o capitalismo, o que não aconteceu de forma homogênea em nível mundial. Marx esclarece este ponto quando se refere à expropriação dos camponeses no contexto da acumulação primitiva: "A história desta expropriação assume diferentes aspectos em diferentes países, e passa por várias fases em ordens diferentes de sucessão, e em diferentes épocas históricas. Somente na Inglaterra, que consequentemente tomamos como exemplo, tem esta forma clássica” (MARX, 1977, p. 876) ${ }^{62}$.

No Brasil, algumas correntes teóricas entendem que o feudalismo teria garantido as condições históricas necessárias para o desenvolvimento das forças produtivas no modo capitalista de produção. Tal interpretação identifica restos feudais na sociedade atual como, por exemplo, algumas relações de trabalho não assalariado no campo. De acordo com essa tese, os camponeses seriam um resquício do feudalismo. Essa visão parte do pressuposto de que a história seria um processo linear que decorre em etapas progressivas e necessárias entre feudalismo e capitalismo, o que significaria imaginar que as relações feudais nos moldes europeus tivessem existido em outras partes do mundo. Caio Prado Jr. contesta este tipo de argumento e esclarece que:

É muito importante a caracterização precisa da verdadeira natureza das relações de trabalho na agropecuária brasileira (...), sobretudo porque em muitos casos o aspecto formal de que se revestem leva ou pode levar a confusões que na prática se revelam da maior inconveniência. É assim a qualificação que frequentemente se faz dessas relações como sendo de natureza "feudal" ou "semifeudal". Em rigor, a expressão "feudal" poderia servir, como qualquer outra de igual carga pejorativa e emocional, para designar certas formas extremamente brutais de exploração do trabalho. Seria uma simples questão de inconveniência lingüística, não fossem as conotações que o termo comporta, e os

\footnotetext{
${ }^{62}$ Original em inglês: "The history of this expropriation assumes different aspects in different countries, and runs through its various phases in different orders of succession, and at different historical epochs. Only in England, which we therefore take as our example, has it the classic form". (MARX, 1977, p.876).
} 
inconvenientes que daí derivam, tanto de ordem teórica, como prática (PRADO Jr., 2007, p. 65).

Mais do que uma simples diferença de opiniões teóricas, é preciso assinalar que Prado (2007) critica o tipo de equívoco metodológico que frequentemente confunde a própria compreensão sobre as formas categorias do modo capitalista de produção. A visão etapista ignora que a passagem do feudalismo para o capitalismo, considerada como situação particular no contexto europeu, ocorre a partir de uma ruptura violenta com as relações de trabalho anteriores, como descrevemos anteriormente em nossa análise sobre a acumulação primitiva. A partir da conversão da violência em "força produtiva", o modo capitalista de produção se reproduz como totalidade em escala mundial, alimentado por relações coloniais modernas.

\section{$\underline{\text { A definicão de Complexo Agroindustrial no contexto brasileiro }}$}

A corrente teórica que imagina resquícios do feudalismo no Brasil influenciou o debate sobre o processo de industrialização da agricultura, principalmente a partir da década de 1960. No caso brasileiro, a "integração" da agricultura à indústria foi descrita por Alberto Passos Guimarães em seu estudo sobre a formação do chamado complexo agroindustrial. Guimarães identifica que o conceito de complexo agroindustrial foi formulado nos Estados Unidos e Europa na década de 1950 e define a transposição deste processo para o Brasil como:

(...) modernização conservadora da agricultura brasileira resultará contraproducente, e até prejudicial, enquanto se limita tão-somente a melhorar os equipamentos e instrumentos mecânicos, como costuma acontecer, conservando-se sem alteração a estrutura anacrônica de propriedade (GUIMARÃES, 1978, p. 22).

A caracterização do modelo que se constituiu como a chamada "modernização conservadora" refere-se ao sistema agrícola dependente de insumos industriais e subsídios do Estado, que mantém a concentração da terra e o poder das oligarquias rurais. O autor menciona como parte deste processo a formação de monopólios industriais e financeiros, que impulsionaram a "integração" e "subordinação" da agricultura, o que teria gerado uma situação de crise estrutural em decorrência de:

(...) uma elevação inevitável das despesas de produção e também uma elevação da composição orgânica do capital, isto é, uma superioridade crescente do capital aplicado em meios de produção sobre o aplicado em mão de obra; e a consequência disso é a queda da taxa média de lucro (GUIMARÃES, 1978, p. $14)$. 
Uma análise comparativa dos censos agropecuários do IBGE (instituto Brasileiro de Geografia e Estatística), de 1940 a 1970, mostra que a produção triplicou no Brasil. Ao mesmo tempo, houve um aumento de vinte vezes no preço dos adubos, de oito vezes no custo de defensivos agrícolas, de trinta vezes nas sementes, mudas e rações, e de quatro vezes em animais, máquinas e veículos. Segundo Guimarães, o custo de produção passou de 7,25\% para 19,88\% em relação ao preço da produção agropecuária. Dados apresentados no livro mostram que em 1976 o setor acumulava uma dívida de 13 bilhões de dólares (GUIMARÃES, 1978, p.131-133).

A elevação do custo do capital constante coincide com a crescente presença de empresas estrangeiras na agricultura brasileira, que monopolizam a produção de insumos e maquinário. $\mathrm{O}$ estudo de Guimarães faz referência à dependência destes produtos, criada quando "agricultores são induzidos à utilização (...) tentados por uma propaganda que lhes promete melhorias milagrosas de produtividade" (GUIMARÃES, 1978, p. 133). O autor identifica a transferência de renda do setor agrícola para o industrial, através da dependência de máquinas e insumos químicos no processo de produção, assim como no momento da comercialização, ambos controlados por monopólios transnacionais.

Para Guimarães (1978), esta é a causa principal da situação que definiu como “crise agrária estrutural”. Esta crise é identificada também na dependência do setor agrícola em relação a subsídios estatais. O processo de formação do complexo agroindustrial agravaria o endividamento e aprofundaria a perda de autonomia dos agricultores em relação a todo o processo produtivo, desde a decisão sobre formas e espécies de cultivo até a comercialização. O autor observa que a propaganda disseminada por empresas do agronegócio acarretou inclusive uma mudança nos hábitos alimentares da população brasileira, através do estímulo ao consumo de comida industrializada.

Apesar de considerar aspectos críticos na formação do chamado complexo agroindustrial, Guimarães adota uma ideia linear de "progresso" em relação ao que significaria desenvolvimento das forças produtivas. Para ele, desenvolvimento seria sinônimo de avanço tecnológico e, portanto, sua análise não chega a aprofundar o aspecto contraditório gerado pelo desequilíbrio na composição orgânica do capital. A perspectiva crítica de Guimarães não é propriamente do modo capitalista de produção 
na agricultura, mas de um tipo de capitalismo, caracterizado como "conservador" ou "desigual". Tal visão é expressa no seguinte trecho:

(...) é bastante evidente que o desenvolvimento industrial, por uma parte, tem sido grandemente benéfico como acelerador do crescimento agrícola. Para fazer face ao considerável aumento da demanda mundial, decorrente do incremento da população e da renda, a agricultura só poderia ter a alternativa de industrializar-se (GUIMARÃES, 1978, p. 16).

Esta citação exemplifica a concepção que entende desenvolvimento como um movimento crescente, benéfico e inevitável, relacionado ao aumento populacional e a um suposto "progresso" agrícola que supriria a maior demanda por alimentos. O autor assume também uma perspectiva determinista quando afirma que a formação do complexo agroindustrial teria ocorrido como uma "transformação progressista, lenta, mas inelutável das forças produtivas pré-industriais da agricultura em forças produtivas industriais", considerada como "lei objetiva universal que conduz basicamente o processo evolutivo da atividade agrícola" (GUIMARÃES, 1978, p. 84). Para ele, a permanência de formas não capitalistas de produção no meio rural seriam "resquícios" de um período "arcaico", "feudal" ou pré-industrial. De acordo com esta perspectiva etapista, a própria história é entendida como um movimento linear, rumo a supostos patamares mais elevados de conhecimento e bem estar.

Mesmo identificando a situação de crise como estruturante na formação do complexo agroindustrial, Guimarães mantém a ideia positivista de que o "progresso" seria capaz, eventualmente, de minimizar as distorções no setor:

E, para contrabalançar o declínio de sua lucratividade, a alternativa foi avançar na utilização do progresso técnico, para alcançar um nível cada vez mais elevado de produtividade. Nesse estrito sentido, a crise agrária representou uma força propulsora dos mecanismos do crescimento agrícola (GUIMARÃES, 1978, p. 16).

Este tipo de argumento considera aspectos "positivos" e "negativos" na modernização da agricultura e, no seu limite, gera a imagem de que haveria um "bom" e um "mau" capitalismo. As características positivas estariam relacionadas ao "avanço" tecnológico, porém a implantação deste modelo significaria a impossibilidade de "autonomia, eficácia econômica e auto-sustentação" da agricultura (GUIMARÃES, 1978, p. 25). A ilusão de que a tecnologia teria a capacidade de solucionar a crise estrutural na agricultura é comum, tanto entre autores de correntes positivistas nos 
meios marxistas, quanto entre os porta-vozes do agronegócio, como verificamos em nossa pesquisa.

Uma das principais contribuições da obra de Guimarães foi perceber a tendência que iria transformar as relações de produção no meio rural através da apropriação da renda da terra por setores financeiros e industriais, referindo-se à "expansão do agropoder ou agribusiness" (GUIMARÃES, 1978, p. 18). Alguns fatores identificados por ele foram o aumento no preço da terra, a expansão da fronteira agrícola, a desnacionalização da agricultura, o êxodo rural, o aumento do desemprego no campo, a permanência dos latifúndios, a constante dependência de subsídios do Estado, a impossibilidade de autonomia na produção de alimentos e o abandono de um projeto de reforma agrária. $\mathrm{O}$ autor avalia que o:

(...) surto de revalorização da empresa rural, acontecimento tão significativo a ponto de ser tratado como uma redescoberta da agricultura,promete transformar o solo agrícola num dos alvos mais cobiçados pelo mundo das finanças internacionais, repetindo-se o que sucedeu com o subsolo minerífero na fase mais aguda das conquistas coloniais dos fins do século XIX (GUIMARÃES, 1978, p. 18).

Além da percepção da tendência de articulação entre o capital financeiro e a agricultura capitalista, Guimarães prevê que os cultivos agrícolas poderiam servir como alternativa para a substituição de combustíveis fósseis: "A fome de alimentos, apesar de ter custado à humanidade milhões de vidas, não irá ocupar, certamente, um lugar tão proeminente na história do capitalismo quanto a fome de petróleo" (GUIMARÃES, 1978, p. 20). As fontes de energia geradas a partir da biomassa representariam, portanto, outro setor estratégico que viria a ser controlado por monopólios industriais.

Dados apresentados no livro indicam que um aspecto central na formação do complexo agroindustrial foi sua relação com o sistema conhecido como cadeia produtiva. Guimarães define a estrutura do complexo agroindustrial incluindo setores industriais "a montante" da agricultura (ou seja, fornecedores de insumos químicos e máquinas agrícolas) e também "a jusante" da agricultura, que assumem o papel de "impor, à sua maneira, as quantidades e os tipos de produtos mais conformes com as exigências da transformação industrial” (GUIMARÃES, 1978, p. 134).

O estudo inclui uma tabela das maiores empresas multinacionais que atuavam no setor agroindustrial brasileiro naquele período. Esta lista, por ordem de faturamento, inclui: Ford Motor, Unilever, Hoechst, E. I. Du Pont de Nemours, Nestlé, British- 
American Tobacco, Phillips Petroleum, Fiat, General Foods, Borden Inc., Ralston Purina, Continental Can, Coca-Cola, CPC International, Phillip Morris, MasseyFerguson, Gervais Danone, Pepsico, Standard Brands, Central Soya, Quaker Oats, Del Monte, Kellog, Heubein, Anderson Clayton (GUIMARÃES, 1978, p. 135).

Além destas empresas, entre as maiores subsidiárias de corporações estrangeiras com negócios no Brasil estavam presentes os grupos Rockfeller, Bunge, Cargill, Basf e Aracruz Celulose. O autor avalia que o impacto da atuação destes grupos significaria que "o poder das proteínas é maior do que o poder atômico" (GUIMARÃES, 1978, p. 143-146). Tal poder é atribuído à formação de monopólios com capacidade de controle sobre a política de preços de produtos agrícolas, além da decisão sobre os tipos de cultivos privilegiados e da manutenção do modelo agrícola baseado no latifúndio.

Posteriormente à obra de Guimarães, a formação do chamado complexo agroindustrial foi descrita por Geraldo Müller (1989) através do que chamou de "transformações notáveis" na agricultura brasileira, iniciadas na década de 1960, caracterizadas pelo uso de insumos industriais e determinadas principalmente pelo mercado externo. Segundo o autor, o setor agrícola passa a ter importância significativa como "mercado comprador" de insumos industriais, o que significaria aprofundar uma "dupla dependência" da agricultura em relação a setores industriais e ao mercado internacional.

Uma das tendências identificadas, que se consolida principalmente nos anos 1970, foi a substituição de importações que priorizaram a utilização de insumos químicos na agricultura, o que Müller relaciona com o aumento da dívida externa (MÜLLER, 1989, p.31). Durante aquele período, metade dos insumos agrícolas no Brasil deixou de priorizar uma base natural e foi substituída por produtos industriais:

(...) no início dos anos 70, o país já apresentava um conjunto de setores agrícolas e industriais interdependentes entre si que pode ser designado complexo agroindustrial. Praticamente metade da produção agrícola era de interesse imediato dos setores demandantes de matérias-primas e praticamente metade das condições de produção na agricultura dependia da indústria de máquinas e demais insumos industriais. (...) algo como metade de seus insumos não mais provêm do "laboratório natural", mas da produção social, na qual comanda o capital industrial e financeiro de corte oligopólico (MÜLLER, 1989, p. 37).

Para Müller, a formação do complexo agroindustrial gerou a "extensão do mercado de dinheiro, de máquinas e insumos industriais para os setores agrícolas" 
(MÜLLER, 1989, p. 60). O autor descreve o papel do Estado como financiador deste processo através da concessão de créditos subsidiados, incentivos fiscais e apoio às exportações. Ele explica que:

(...) o Estado é o agente que possibilitou (no período de 1965-80) a conversão e que, efetivamente, converte o capital social total que opera na agricultura em capital em geral. É que o Estado erigiu-se como capitalista financeiro por excelência, facultando a existência de capitais agrícolas de alta composição orgânica (MÜLLER, 1989, p. 56-57).

Esta citação se refere à função do Estado como central na transferência de maisvalia social para possibilitar a formação de monopólios agroindustriais privados. Müller supõe que, se o Estado não fosse capaz de exercer este papel, ocorreria uma "desenfreada concorrência intercapitalista entre proprietários e as organizações que operam na agricultura industrializada" (MÜLLER, 1989, p. 58). Tal interpretação vê a atuação do Estado como fundamental para propiciar a tendência de monopolização do capital, contra as características típicas do capitalismo concorrencial. Porém, esta tese gera a impressão equivocada de que existiria oposição entre proprietários rurais e indústria capitalista.

A partir dos anos 1950, período conhecido como "desenvolvimentista" no Brasil, articula-se o que Müller chama de "tríplice aliança" entre o capital nacional, o capital internacional e o Estado, que seria "a forma nacional de expansão do capitalismo oligopólico do pós-guerra num país atrasado de periferia” (MÜLLER, 1989, p. 31). Este tipo de análise é direcionado a criticar um determinado tipo de desenvolvimento que, supostamente, seria incapaz de superar o "atraso" da periferia em relação ao centro do capitalismo.

Como resultado deste tipo de desenvolvimento, Müller cita dados sobre a diminuição da população rural no Brasil, que passa de $70 \%$ em 1940 para 30\% em 1980. O autor atribui estes números à suposta criação de uma "nova classe média" no campo brasileiro, que conviveria com uma "assombrosa pobreza da grande maioria". O livro descreve tal fenômeno como "desenvolvimento fáustico", e explica que, "O desenvolvimento é uma tragédia: Fausto finge que pode criar um novo mundo com mãos limpas, mas ele ainda não está preparado para aceitar a responsabilidade sobre a morte e o sofrimento humano" (MÜLLER, 1989, p. 17-26). 
O autor utiliza como base em sua análise uma visão positivista, inspirada em Kautsky, sobre a agricultura capitalista. O estudo relaciona as mudanças ocorridas para a formação do complexo agroindustrial no Brasil com "conquistas da ciência moderna". Este tipo de interpretação imagina que as causas determinantes para a industrialização da agricultura seriam o "progresso" e as chamadas "conquistas" tecnológicas. Müller, porém, traz algumas nuances e considera o complexo agroindustrial como "unidade analítica da acumulação de capital". Nesse sentido, observa particularidades que a atividade agrícola incorpora, principalmente pelo fato de ter a "terra como meio direto de produção" (MÜLLER, 1989, p. 23-31).

A visão "idealista" de desenvolvimento é contestada por McMichael (2000) em sua crítica à ideia de que o processo de industrialização seria o caminho natural para superar a divisão internacional do trabalho entre países industrializados e aqueles predominantemente agrícolas. O autor analisa o contexto geopolítico que levou os Estados Unidos a se converterem em uma "potência agrícola", através da passagem do sistema "agro-colonial" para o "agro-industrial". O modelo estabelecido na Inglaterra no início do período de industrialização intensificou a formação do proletariado internamente e incentivou a importação de matérias primas das colônias. A partir do Século XX, os Estados Unidos rompem com este modelo e incentivam políticas de "integração" entre agricultura e indústria. Tal sistema, que passou a ser chamado de "agronegócio", foi adotado também na Europa e nos países periféricos, porém com características que "intensificaram a divisão internacional do trabalho associada ao colonialismo" (McMICHAEL, 2000, p. 129).

È possível constatar que a formação do complexo agroindustrial aprofundou o papel do Brasil como país fornecedor de matérias primas agrícolas, a partir de uma demanda externa. Além disso, este modelo acarretou uma dependência crescente de acesso a créditos para cobrir custos de produção com maquinário e insumos químicos, controlados por empresas multinacionais. De acordo com Müller, este processo teria acarretado também uma modificação no papel da propriedade da terra, explicada no seguinte trecho:

(...) para produzir na agricultura, não basta mais ser proprietário de terras, ainda que esta seja um pressuposto da produção (...) deve-se levar em conta um certo montante de bens de capital sem o qual a produção agrícola pode ser rapidamente posta em xeque pela penalização dos valores. Neste sentido, a terra subordina-se ao capital. Na verdade, esta formulação é imprecisa. É o trabalho 
agrícola que se subordina ao capital industrial e financeiro, no contexto de uma industrialização crescente da agricultura, processo no qual a terra-matéria perde suas forças determinadoras das condições de produção em favor da terra-capital (MÜLLER, 1989, p. 39).

Müller observa que a chamada "industrialização" no campo brasileiro incorporou cerca de $30 \%$ do total de atividades agrícolas, ou seja, $70 \%$ da agricultura permaneciam nos moldes anteriores. Estes dados ilustram a conclusão do autor, que descreve a agricultura camponesa a partir da "subordinação efetiva dos tempos de trabalho necessário e excedente à dinâmica do capital em mercados com características crescentes de concorrência oligopólica" (MÜLLER, 1989, p. 67).

Delgado (2012), por sua vez, observa que o chamado "complexo agroindustrial", atualmente denominado de "agronegócio", é alavancado por um conjunto de medidas estatais que possibilitam a abertura de linhas de crédito especiais para o setor. $\mathrm{O}$ foco desta análise é o necessário entrelaçamento do agronegócio com o capital financeiro, como afirma o autor:

(...) a discussão dos complexos agroindustriais, ou cadeias agroindustriais como posteriormente se enfatizou, é suficientemente embasada para localizar um dos recortes empíricos então invocados. (...) Mas no caso brasileiro, o mercado de terras e o sistema de crédito rural, ambos sob patrocínio fundamental do Estado, são peças essenciais para possibilitar a estratégia de capital financeiro na agricultura (DELGADO, 2012, cap. 5).

Como já abordamos anteriormente, a investigação de Delgado (2012) sobre o papel do capital financeiro no processo de crise- acumulação da agricultura capitalista é fundamental, principalmente no sentido de desconstruir o discurso ufanista que exalta supostas "vantagens" do agronegócio. A seguir, utilizaremos uma pesquisa sobre o discurso oficial que propagandeou este modelo agrícola em sua fase inicial, entre as décadas de 1960 e 1980, como forma de exemplificar nossa tese.

\section{Política Agro-Pecuária no Brasil de 1960 a 1990: Análise do jornal Gazeta}

\section{$\underline{\text { Mercantil }}$}

Com a intenção de ilustrar o processo de transformação na agricultura brasileira, a partir da década de 1960, realizamos uma pesquisa no jornal Gazeta Mercantil. A escolha de concentrar a pesquisa daquele momento histórico neste jornal teve como objetivo desvendar o discurso considerado hegemônico entre as classes dominantes no Brasil, já que representava o principal periódico econômico da época. Os exemplares pesquisados foram selecionados com base em sua periodicidade e também na 
disponibilidade encontrada nos arquivos da Biblioteca Nacional no Rio de Janeiro, onde fizemos o trabalho. O período total pesquisado na Gazeta Mercantil abrangeu os anos de 1962 a 2002, mas dividiremos nossa exposição com base nas mudanças de linguagem e de conteúdo do jornal, principalmente em relação à palavra-chave utilizada para descrever o modelo agrícola predominante. A análise de reportagens e opiniões sobre a política agrícola contidas no jornal contribuiu com nossa compreensão sobre os processos sociais, econômicos e políticos que vieram a gerar o termo "agronegócio".

Em 1962, o jornal dedicava várias páginas de seu primeiro caderno ao tópico Agro-Pecuária. A maioria das matérias sobre agricultura tratava de temas como volume de produtos exportados, movimentação nos portos, cotação no mercado financeiro, atas ou declarações de associações agrícolas, notícias sobre linhas de crédito e políticas públicas. Naquele período, o café era o principal produto de exportação e as matérias do jornal demonstram que havia grande preocupação com a imagem deste setor no exterior. Por exemplo, a edição de domingo, 21 de outubro de 1962, traz como manchete principal: "Presidente João Goulart cria fundo agro-pecuário". O jornal destaca também: "Urge a intensificação da propaganda específica do café nacional, dentro dos moldes realizados por outros países produtores e exportadores de café" (p. 3).

Como a política agrícola brasileira historicamente esteve voltada para o mercado externo, o jornal dava destaque à cotação de produtos agropecuários nas bolsas de valores internacionais. Além do café, o jornal monitorava a cotação de outras commodities brasileiras, como carne, milho, açúcar, soja, trigo, leite, aveia, arroz, feijão, algodão, centeio, cacau, óleo de mamona, borracha, cravo da Índia, canela da Índia e couros. Havia ainda uma discussão em torno da possibilidade da criação da Associação Latino-Americana de Livre Comércio (ALAC), no sentido de facilitar a integração regional, além de um tratado centro-americano entre El Salvador, Honduras, Nicarágua, Guatemala e Costa Rica. Um artigo de 23 de outubro de 1962 afirma:

Progride o mercado comum na América Central [visando], eliminar barreiras aduaneiras, padronização das tarifas externas, início de um Banco Regional de Desenvolvimento, investimentos na indústria, melhoria na rede de transportes, diversificação agrícola, nova unidade monetária que circule entre as naçõesmembros (Gazeta Mercantil, 23/10/1962).

O jornal não se posiciona contra o regime militar no Brasil, porém defende relações regionais de comércio com a América Latina. Há certo espaço para o debate sobre a concentração da estrutura fundiária brasileira, mas a prioridade do jornal é 
expressar uma posição favorável ao apoio estatal para o setor agropecuário extensivo. A conjuntura internacional era marcada pela Guerra Fria e se iniciava o processo mais intenso de exportação de capitais, que permitiu certo nível de industrialização no país, mas que viria a resultar na dívida externa brasileira. Em 23 de outubro de 1962 a Gazeta Mercantil anunciava na primeira página que, "60 milhões de dólares em ouro brasileiro serão transferidos para banco de Nova Iorque”. Este artigo mostra também o poder que os militares exerciam no Brasil:

O Conselho de Segurança Nacional, do qual fazem parte todo o conselho de Ministros e os chefes de Estado Maior das pastas militares, em sua última reunião, concordou que sejam transferidas para o Federal Reserve Bank, de Nova Iorque, cerca de 60 milhões de dólares, em ouro, que o Brasil possui em suas minas de Morro Velho, para permitir condições ao Brasil de conseguir empréstimos junto ao Fundo Monetário Internacional (Gazeta Mercantil, 23/10/1962).

A mesma edição, de 23 de outubro, anuncia a política fundiária implantada no Peru, onde, ao contrário de outros países latino-americanos, havia um governo militar de esquerda. $\mathrm{O}$ artigo na explica a "Concepção da junta militar do Peru sobre as bases da reforma agrária do País":

A finalidade da reforma agrária, segundo expressa as "bases", consiste em estabelecer uma autêntica justiça social agrária, dotar progressivamente de terras a classe camponesa, elevar o nível alimentício nacional, corrigir os atuais defeitos da estrutura agrária, impedindo o latifúndio e o minifúndio, difundir a pequena e média propriedades e garantir o direito de preferência a terra ao camponês que a trabalha (Gazeta Mercantil, 23/10/1962, p. 7).

As próximas edições da Gazeta Mercantil que aparecem nos arquivos da Biblioteca Nacional têm início em setembro de 1975. A descontinuidade da disponibilidade do jornal para acesso público coincide com o período da ditadura militar no Brasil. Em 1975, ainda sob o regime militar de Ernesto Geisel, identificamos a permanência de artigos sobre políticas de integração do comércio regional latinoamericano. No dia 10 setembro de 1975 a manchete de primeira página anuncia: "Mais força para as Multilatinas - Necessidade de criação de um sistema econômico LatinoAmericano (SELA)". O artigo propõe a criação de uma "empresa de petróleo Argentina-Venezuela-México e do setor de alimentos", com o objetivo de "reduzir a dependência latino-americana de fontes, capitais e tecnologia estrangeira". Esta proposta foi feita pelo presidente mexicano Luis Echeverria, na VI Conferência Ministerial da Organização Latino-Americana de Energia (OLADE). 
As matérias sobre política agrícola demonstram que havia maior controle do Estado sobre estoques de alimentos e sobre as cotas de exportação no Brasil, além de maior grau de diversificação agrícola. A matéria de primeira página do dia 10 de setembro de 1975 indica estes fatores ao se referir ao caso do Rio Grande do Sul:

RS pode deixar de ser exportador: Com base no desempenho da pecuária e das principais lavouras no RS nos últimos 11 anos, os técnicos fizeram projeções que indicam que em 1985, quando o Estado terá entre 14 e 15 milhões de habitantes, o arroz, soja, trigo, lã, cebola e fumo serão os únicos produtos que apresentarão excedentes de oferta (excedente exportável). (...) Feijão, carne suína e bovina deixarão de figurar na pauta de exportação do Estado (Gazeta Mercantil, 10/09/1975, p. 1).

Estes dados se baseiam em uma pesquisa da Secretaria de Agricultura do Rio Grande do Sul. Apesar de identificarmos este tipo de preocupação com a disponibilidade de alimentos para o mercado interno, o periódico continua a destacar com regularidade o monitoramento da cotação de produtos agrícolas nas bolsas de valores internacionais. As principais commodities citadas eram café, milho, trigo, soja, feijão, açúcar, cacau, borracha e algodão.

No final da década de 1970, já se identificava uma tendência neoliberal no discurso oficial, com menção à necessidade de desregulamentação estatal e abertura comercial. Em 16 de agosto de 1977 a Gazeta Mercantil traz, em primeira página, uma declaração do Ministro do Comércio da Inglaterra, Edmund Dell, com a manchete:

Protecionismo do Brasil, segundo Dell: Por ser talvez o país mais desenvolvido entre aqueles considerados em vias de desenvolvimento, o Brasil desempenha um importante papel no concerto da economia mundial. Por isso, a nossa esperança é de que, na medida em que sua situação econômica melhore, o Brasil passe a contribuir também para a melhoria das relações de comércio internacional, abrindo mais seus mercados às negociações multilaterais (Gazeta Mercantil, 16/08/1977, p. 1).

Ainda segundo o Ministro, "O balanço das trocas comuns não tem mostrado privilégio para os britânicos”. A mesma edição do jornal indica que o Brasil tinha um superávit na balança comercial equivalente a US\$337 milhões de dólares naquele período.

O jornal mantinha uma página especial com o título Agropecuária. Em 16 de agosto de 1977, é possível notar uma tendência de maior desregulamentação do mercado agrícola, através da manchete: "Críticas à política oficial: Produtores criticam política do Instituto Brasileiro do Café (IBC) como excesso de intervencionismo do 
governo no mercado". A matéria explica que, com a queda do preço do café no mercado internacional, o IBC passa a centralizar a compra do produto. Seguindo essa mesma linha, uma matéria publicada no dia 30 de junho de 1979 mostra o papel do Estado na produção de cana-de-açúcar, através do Instituto do Açúcar e do Álcool (IAA), que admite intervir no setor:

Grupo Atalla: Governo espera que as usinas não venham a sofrer uma intervenção - Se uma usina açucareira paralisa suas atividades por 8 dias, o IAA é obrigado, juridicamente, a assumir a empresa, disse o Ministro da Indústria e Comércio João Camilo Penna, se referindo ao Estatuto da Lavoura Canavieira (Gazeta Mercantil, 30/06/1979, p. 9).

Este período foi marcado pela manifestação da crise econômica mundial, que teve como um dos principais efeitos a forte alta no preço do petróleo. Em 5 de julho de 1979 a manchete de primeira página da Gazeta Mercantil alerta para a "iminente economia de guerra". Na página 4, o editorial conclui que, "Finalmente, acordamos para o impasse energético" e elogia as "medidas enérgicas de contenção de consumo" anunciadas por João Figueiredo. Na mesma edição (p. 7), o jornal publica um discurso de Figueiredo que propõe: "Em grande escala e a custos aceitáveis só podemos definirnos imediatamente pelo álcool etílico e pelo carvão. Não obstante, não podemos desprezar outras soluções de baixo custo. Muito especialmente, a energia solar." $\mathrm{O}$ então Ministro do Planejamento, Mario Henrique Simonsen, segue a mesma linha e defende a "racionalização do consumo", além da intensificação da produção nacional de petróleo para diminuir a necessidade de importações. Em 12 de outubro de 1979, o jornal publica:

As metas do governo: 316 novas destilarias - a nova dimensão do Pró-Alcool, cuja meta inicial é a produção de 10,7 bilhões de litros por ano em 1985, exigirá a implantação de 316 novas destilarias, demandando a aplicação de recursos da ordem de US\$ 4 bilhões até aquele ano e a incorporação de 1,4 milhão de hectares de novas terras cultivadas de cana-de-açúcar (Gazeta Mercantil, 12/10/1979).

Um dos temas centrais tratados no jornal era o papel regulador do Estado em relação ao mercado agrícola, no sentido de garantir a produção de alimentos para atender a demanda interna. Em 30 de março de 1979, a página que trata de Política Agrícola traz uma entrevista com o Ministro da Agricultura na época, Delfim Neto. Segundo o jornal, ele era "considerado um dos principais teóricos do modelo exportador". $\mathrm{Na}$ entrevista intitulada "O papel da agricultura segundo Delfim", o ministro afirma que: 
A agricultura brasileira não deve pautar-se pelas oscilações de preços do mercado externo e nem mesmo pela imperícia dos exportadores. (...) $\mathrm{O}$ desenvolvimento agrícola brasileiro, antes de preocupar-se com exportações, visa aumentar a demanda interna de alimentos, ajudar a combater a inflação e só então, secundariamente, contribuir para o equilíbrio da balança comercial (Gazeta Mercantil, 30/03/1979, p. 12).

O posicionamento de Delfim Neto reflete a política do regime de João Figueiredo que anuncia, no mesmo período, apoio à produção de alimentos para o mercado interno como forma de diminuir o custo real da força de trabalho para a indústria, já que comida mais barata significa a possibilidade de se manter salários em um patamar mais rebaixado. Desta forma, os subsídios estatais para a produção de alimentos funcionam como meio de baratear os custos de reprodução dos trabalhadores, em um momento de industrialização no Brasil.

O debate sobre o modelo agrícola e fundiário continua a gerar polêmica nos artigos da Gazeta Mercantil. Uma matéria publicada no dia 3 de abril de 1979 demonstra que havia uma expectativa de que o governo poderia promover a reforma agrária. Dados daquela época indicam que a maioria da produção de alimentos estava a cargo da pequena agricultura, o que permanece até a atualidade, apesar de o Brasil apresentar um dos piores índices de concentração de terras no mundo, o que se constitui em um problema histórico, como podemos identificar no trecho a seguir:

A Confederação Nacional dos Trabalhadores na Agricultura e as 21 federações a ela filiadas emitiram nota criticando o desinteresse do Ministro Delfim Neto da Agricultura, pela reforma agrária, apesar de o presidente Figueiredo haver prometido dar prioridade a agricultura e de os pequenos proprietários, posseiros, parceleiros e arrendatários serem responsáveis por mais de $40 \%$ da produção agropecuária e por mais de $50 \%$ da produção de alimentos no País, mesmo trabalhando com somente $20 \%$ da área explorada. (...) O documento afirma que a decisão presidencial de dar prioridade a agricultura criou nova expectativa entre os trabalhadores em relação a uma possível reforma agrária ampla e massiva. (...) O desequilíbrio de nossa estrutura agrária é bem conhecido, situando-se o Brasil, atualmente, na faixa dos países com maiores índices mundiais de concentração da propriedade da terra, já que os latifundiários controlam mais de $70 \%$ das terras e canalizam a maior parte do crédito e dos incentivos, diz a nota (Gazeta Mercantil, 03/04/1979 p. 12).

Esta matéria sintetiza um quadro de monopólio da terra, que se mantém historicamente no Brasil. Da mesma maneira, não houve mudança em relação ao papel do Estado e sua prioridade em conceder crédito e subsídios para a agricultura extensiva. A seguinte citação aborda este tema a partir de estudo do economista Guilherme Delgado: 
Crédito rural: Discriminação aos pequenos - O 'saco agrícola' continua a discriminar os pequenos produtores, responsáveis por grande parte da produção de alimentos básicos. O novo critério-concessão de maiores créditos por maior produtividade - privilegia os grandes produtores, diz Guilherme Delgado, do Centro de Estudos e Pesquisas Rurais. (...) O critério de produtividade foi considerado elitista e a versão de que ele significa um estímulo à introdução de inovações tecnológicas no campo não foi aceita (Gazeta Mercantil, 30/06/1979 p. 10).

Na mesma edição, o jornal traz uma tabela com dados do Instituto Brasileiro de Geografia e Estatística (IBGE) indicando o peso da produção de alimentos da pequena agricultura, realizada em áreas menores de 50 hectares. A percentagem de sua participação na produção nacional era a seguinte: Milho: 64,2 / Feijão: 73,2 / Mandioca: 78,5 / Arroz: 43,3 / Algodão: 58,2 / Soja: 50,8 / Trigo: 36,7. Estes números são semelhantes aos encontrados nos censos mais recentes do IBGE e revelam que a agricultura camponesa produz a maior parte dos alimentos para consumo interno no Brasil, apesar de não contar com acesso a terra e crédito na mesma proporção que é concedida pelo Estado à grande exploração.

\section{$\underline{\text { A utilizacão do termo commodities }}$}

No início dos anos 1980 a Gazeta Mercantil passa a usar o termo commodities como subtítulo das páginas dedicadas aos temas relacionados à produção agropecuária. Em 1 de maio de 1980, o editorial tem como título, "A defesa natural das exportações de commodities”. Entretanto, é possível identificar um período em transição no discurso do jornal, que em algumas matérias adota a retórica neoliberal baseada no princípio do "livre comércio", porém mantém a defesa de que o Brasil fortaleça associações de comércio regional, como é o caso dos produtores de café na América Latina. A citação abaixo é parte do editorial:

É bastante imprecisa a classificação de cartel que vem sendo dada a Pan-café, empresa que deverá ser criada proximamente para possibilitar uma ação conjunta dos países latino-americanos exportadores de café para defesa dos preços do produto no mercado internacional. (...) O que se procura, portanto, não é constituir cartéis impossíveis, mas sim fazer uso de instrumentos que possibilitem relações de troca um pouco mais equânimes (Gazeta Mercantil, 01/05/1980, p. 4).

Ainda se identifica que o Estado exerce um papel significativo no controle de estoques de alimentos, através de políticas de subsídios que visavam reduzir as importações agrícolas, como mostra a seguinte matéria de primeira página: 
O subsídio do trigo pode acabar - É quase certo que, com a oferta de arroz assegurada, o subsídio ao trigo pra os consumidores possa, agora, ser retirado. O arroz poderá reocupar seu papel na dieta das populações de renda mais baixa que, com o preço do trigo subsidiado, acostumaram-se a substituir o arroz por farináceos como o macarrão (Gazeta Mercantil, 07/05/1980, p. 4).

O discurso neoliberal estava apenas começando a se tornar dominante no Brasil, mas passa a aparecer com mais frequência especialmente em função da cobertura dada às políticas econômicas adotadas na Inglaterra e Estados Unidos naquele contexto. Por exemplo, um artigo de primeira página intitulado "O estilo grave da Senhora Thatcher", avalia que:

Em seu primeiro ano como chefe de governo, Margaret Thatcher provou que cultiva, como poucos políticos, a virtude da coerência. Durante a campanha eleitoral, ela prometeu que diminuiria os gastos públicos, reduziria a dívida interna e a presença do Estado na sociedade, reforçaria a lei e a ordem e apararia o poder dos sindicatos (Gazeta Mercantil, 03/05/1980, p. 1).

Em 14 de junho, outra análise do jornal segue a mesma linha, desta vez tratando da influência que o modelo econômico adotado na Inglaterra estaria exercendo entre empresas e políticos do Partido Republicano nos Estados Unidos: "Os Estados Unidos assimilam a política de Thatcher - A política econômica do governo Thatcher está sendo observada atentamente pelos porta-vozes das empresas norte-americanas e pelos líderes republicanos" (Gazeta Mercantil, 14/06/1980, p. 4).

Em relação à conjuntura brasileira, o jornal ensaia um apoio tímido ao processo chamado de "abertura democrática", marcado por grandes protestos de operários, principalmente em São Paulo. A edição de 3 de maio de 1980 reproduz um artigo de opinião publicado originalmente no jornal americano Financial Times, que anuncia uma possível mudança política no Brasil, com a seguinte manchete: “Todos precisam acostumar-se ao novo tempo do Brasil”. O conteúdo do artigo destaca a prisão de Lula durante as greves do movimento sindical: “A detenção, pela polícia de São Paulo, de Luis Inácio da Silva, o Lula, o mais conhecido líder sindical do Brasil, é prova da dificuldade e complexidade do processo de liberalização em andamento no maior país da América Latina”. Na matéria seguinte é possível identificar o grau de repressão que persistia no Brasil: "Metalúrgicos: governo mantém proibição de assembléias públicas Uma nota do chefe do Deops, delegado Romeu Tuma, diz que a liberação dos logradouros públicos para manifestações valeu apenas para o dia do trabalhador" (Gazeta Mercantil, 03/05/1980, p. 4-5). 
No que diz respeito à política agrícola, o jornal destaca "novas tendências no mercado mundial", principalmente para anunciar o maior potencial de abertura de exportações de grãos do Brasil para outros países. Esta medida coincide com a permanência do boicote econômico dos Estados Unidos à União Soviética. Como vimos no capítulo anterior, antes do conflito entre os dois países no Afeganistão, a União Soviética era um dos principais mercados importadores de grãos dos Estados Unidos. $\mathrm{Na}$ década de 1980, empresas estadunidenses passam a facilitar o fortalecimento da produção de soja no Brasil, que tem seu mercado ampliado pelo aumento da demanda na China e em exportadores de petróleo como Venezuela e países no Oriente Médio. Por sua vez, os Estados Unidos e os países europeus buscavam expandir as exportações do setor industrial aplicado à agricultura em âmbito mundial, através do modelo conhecido como "revolução verde", que gerava maior dependência de máquinas e insumos químicos.

Em 10 de maio de 1980 a manchete de primeira página da Gazeta Mercantil possui uma conotação otimista em relação ao aumento das exportações brasileiras e prevê: "Ganhar com alimentos - A tendência até agora favorável dos preços dos principais produtos agrícolas de exportação deverá assegurar ao Brasil, este ano, a receita prevista de US\$ 7 bilhões com a comercialização do café, soja, açúcar e cacau”. Naquela mesma edição, o jornal traz uma matéria intitulada "Crédito para investimento", que revela o alto custo do subsídio governamental para a agricultura:

O governo já tem concentrado seus esforços no apoio ao produtor, mantendo a conta do financiamento de custeio em aberto e garantindo a compra de qualquer excedente de produção. Os recursos para crédito de custeio seriam, este ano, da ordem de Cr\$670 bilhões. Mas, segundo o ministro, estes números servem apenas para efeito de planificação do orçamento. 'Na realidade, não haverá limite para crédito de custeio. As agências do Banco do Brasil não têm recusado nenhum pedido desse tipo de financiamento,' diz o Ministro da Agricultura Amaury Stabile (Gazeta Mercantil, 10/05/1980, p. 11).

Para efeito de avaliação do peso orçamentário do crédito agrícola, verificamos que o câmbio do dia em que estes montantes foram publicados era de \$1 dólar para $\$ 50,135$ cruzeiros. Portanto, o governo anunciava um investimento equivalente à $\$ 13$ bilhões de dólares no setor enquanto a expectativa de receitas com exportações era de $\$ 7$ bilhões de dólares. Mesmo concedendo este volume de crédito, o governo foi alvo de críticas dos ruralistas, como mostra a matéria publicada em 28 de junho de 1980: "Política agrícola: Custeio - as críticas da CNA - Os produtores rurais agrupados na 
Confederação Nacional da Agricultura - CNA, não ficaram satisfeitos com os novos níveis de valores básicos de custeio (VBCs) fixados pelo governo" (p. 11). Segundo a tabela de dados publicada na mesma edição, o governo cobriria o custeio de vários produtos, nas seguintes proporções: Arroz: 81\% / Algodão 85\% / Amendoim 86\% / Feijão 86\% / Milho 79\% / Soja 69\% / Sorgo $73 \%$.

Os dados anunciados pelo governo mostram que o montante de investimentos públicos para as exportações agrícolas representava o dobro do saldo da balança comercial dos principais produtos exportados. Faria sentido, portanto, questionar a suposta "vantagem" de se investir tantos recursos neste setor. Porém, o discurso oficial destaca com frequência a suposta "importância" das exportações agrícolas para a economia brasileira.

Em uma entrevista publicada na Gazeta Mercantil em 14 de junho de 1980, o então Ministro da Agricultura, Amaury Stabile, afirma que o propósito do governo seria “tornar a agropecuária prioritária em relação aos demais setores econômicos (...) conter o aumento dos preços dos alimentos, permitir o aumento da renda real dos trabalhadores, gerar excedentes exportáveis". Esta citação revela que o governo visava assegurar que os preços dos alimentos se mantivessem baixos no mercado interno, como meio de prevenir eventuais pressões dos trabalhadores por aumento salarial, ao mesmo tempo em que financiava a exportação de commodities agrícolas. Em outro trecho da entrevista, o ministro prevê a necessidade de extensão territorial da agricultura: "Se o Brasil pretende realmente usar a agropecuária para sair da crise econômica atual, a área cultivada não poderá crescer a uma taxa anual inferior a 7\%" (Gazeta Mercantil, 14/07/1980, p. 9).

Durante aquele período, uma das prioridades do governo brasileiro era subsidiar a produção de cana, tanto para açúcar quanto para o programa de incentivo ao combustível denominado de Pró-álcool. A manchete de primeira página do dia 14 de junho de 1980 anuncia: "Será a maior safra de açúcar - O Brasil vai produzir este ano 7,8 milhões de toneladas de açúcar, 1,2 milhões a mais do que no ano passado e 4,1 bilhões de litros de álcool, 100 milhões a menos do que a meta projetada pelo Próálcool” (Gazeta Mercantil, 14/07/1980, p. 1). O Pró-álcool, iniciado como alternativa para minimizar os efeitos da crise econômica internacional e do aumento do preço do petróleo nos anos 1970, se manteve nos anos 1980 até a interrupção dos subsídios 
estatais, sem os quais muitas usinas faliram. É possível observar que naquele momento alguns setores expressavam preocupação com a expansão do monocultivo de cana e consequente substituição de lavouras de alimentos. A reportagem de 28 de junho de 1980 alerta que:

Avanço na cana preocupa - $\mathrm{O}$ avanço das lavouras de cana-de-açúcar é hoje uma das maiores preocupações de Mogi-Mirim, um município com cerca de 43 mil hectares de área, situado a $150 \mathrm{~km}$ de São Paulo. 'Nosso medo é que venha a acontecer o mesmo que aconteceu com Piracicaba, Americana e Santa Bárbara d'Oeste, municípios que hoje têm cerca de $90 \%$ do seu território ocupado com lavouras de cana', diz José Maria Molim, diretor do Dep. De Agricultura de Mogi (Gazeta Mercantil, 28/06/1980, p. 11).

A reportagem mostra ainda que, em resposta a tal preocupação, o município de Mogi-Mirim estabeleceu um zoneamento agrícola para impedir a expansão da cana sobre áreas de produção de alimentos: "O objetivo do zoneamento é fazer com que Mogi se abasteça de todos os gêneros agropecuários, pois aqui particularmente se produz tudo: feijão, arroz, milho, soja, algodão, café e produtos hortifruticulas" (Gazeta Mercantil, 28/06/1980, p. 11).

Verificamos também que os problemas trabalhistas eram frequentes na produção de cana. Por exemplo, em 10 de janeiro de 1985, o jornal apresenta uma cobertura da greve de trabalhadores rurais no setor canavieiro em Guariba (SP), que também ocorreu em outros municípios, como Ribeirão Preto, Barrinha, São Joaquim e Jaboticabal. No dia 21 de janeiro, o jornal destaca o desfecho das greves dos cortadores de cana no estado de São Paulo: "Bóias-frias conseguem diária de Cr\$12,5 mil - Quinze dias após o início do movimento grevista dos bóias-frias de Guariba, que se alastrou por toda a região canavieira de Ribeirão Preto, um acordo prevê o piso diário de Cr\$12,5 mil após o fim da greve" (Gazeta Mercantil, 28/06/1985, p. 6).

Naquele momento o câmbio era equivalente a $\$ 3,8$ cruzeiros para $\$ 1$ dólar. Portanto, os trabalhadores conseguiram um piso salarial de $\$ 3,2$ dólares por dia. A greve, considerada histórica, gerou reação por parte do Diretor da Organização de Plantadores de Cana de Guariba, Roberto Rodrigues, que defendeu a negociação com os trabalhadores para resolver o impasse causado pela multiplicação das greves. Contudo, a entrevista publicada em 22 de janeiro de 1985 trata da concessão de aumento de salários como justificativa para garantir "benefício social": 
Usineiros devem abrir mão de parte da renda, diz empresário - Se não houver uma investida séria no sentido de resolver as causas das greves que vêm acorrendo com os trabalhadores volantes da cana-de-açúcar, o problema sempre voltará. A intransigência dos usineiros apenas alimenta a situação de conflito. Eles precisam tomar consciência de que devem abrir mão de parte da renda pelo beneficio social (Gazeta Mercantil, 22/01/1985, p. 6).

Naquela época, em meados dos anos 1980, o discurso do jornal em relação à conjuntura brasileira passa a ser permeado pelo processo de "redemocratização", porém sem expressar críticas ao regime militar ainda vigente. Pelo contrário, a ideia da necessidade de se manter a "segurança" e a "estabilidade" do país, supostamente garantidas pela ditadura militar, permanecia naquele momento. $O$ seguinte texto editorial defende que, "O processo político evoluiu no sentido de permitir uma sucessão tranquiila, esperando-se que a abertura democrática se consolide com a convocação de uma Assembléia Nacional Constituinte, a partir das eleições de 1986" (Gazeta Mercantil, 29/12/1984, p. 4).

Um artigo publicado na mesma edição, intitulado "Liberdade, Base da Segurança" (p. 5), afirma: "O binômio 'segurança e liberdade' deve governar a nova etapa da vida política do País, que se iniciará com a provável eleição de Tancredo Neves no Colégio Eleitoral em 15 de janeiro". O jornal traz ainda dados sobre uma pesquisa do IBOPE sobre a disputa eleitoral, que indicava o apoio de $62,5 \%$ da opinião pública ao candidato Tancredo Neto e apenas 12,3\% para o oponente Paulo Maluf. A matéria menciona propostas de Tancredo Neves para a agricultura, que incluiriam:

(...) dobrar a produção de grãos de 50 milhões para 100 milhões de toneladas ao longo de 4 anos de mandato, continuar subsidiando o crédito rural tanto para produção quanto para comercialização. A agricultura ocupa lugar prioritário tanto para exportação quanto para mercado interno. Parte dos excedentes irá para programas alimentares de emergência (Gazeta Mercantil, 29/12/1984, p. $5)$.

É interessante notar que estas propostas combinam, ao mesmo tempo, apoio às exportações e ao mercado interno. Como verificamos anteriormente em relação à década de 1970, percebemos uma preocupação no discurso oficial com a manutenção de estoques de alimentos para consumo interno. A mesma edição do jornal traz uma manchete de primeira página que indica elementos de crise nos segmentos que dependiam do mercado externo:

Os desafios à exportação agrícola - Os principais produtos agrícolas que o País comercializa no exterior - café, cacau, açúcar, soja e derivados, suco de laranja e carne bovina, mantiveram, em 1984, a participação de $32 \%$ na receita 
brasileira de exportação. Neste ano que se inicia, os exportadores devem enfrentar obstáculos, como cotações em queda, um mercado internacional conturbado por um dólar firme, pela lenta recuperação da economia européia e pela crescente onda de protecionismo (Gazeta Mercantil, 29/12/1984, p. 1).

A matéria inclui uma tabela mostrando que em 1977 a exportação de produtos agrícolas chegava a 50,7\% do total produzido na agricultura brasileira e que, durante os anos 1980, este percentual caiu para cerca de $30 \%$. Estes dados poderiam indicar que a política agrícola do governo brasileiro passou a dar maior prioridade ao mercado interno, mas parece mais provável que tenham sido influenciados pelo contexto de recessão econômica mundial, que causou contração no mercado externo. Mesmo com o aumento da percentagem de alimentos comercializados internamente, o preço da cesta básica permanecia alto, como mostra a reportagem intitulada " $\mathrm{O}$ alto custo da alimentação". O texto indica que em 1984 a cesta básica em São Paulo custava o equivalente a $\mathrm{Cr} \$ 100.825,47$ enquanto o salário mínimo era de \$97.176,00 (Gazeta Mercantil, 29/12/1984, p. 3).

No dia 9 de janeiro de 1985, a Gazeta Mercantil anuncia na primeira página que o superávit comercial do Brasil teria alcançado US\$13 bilhões em 1984. Ainda de acordo com o jornal, este seria um "recorde histórico" e representava mais do que o dobro do ano anterior. Os números publicados indicavam que o setor agropecuário teria sido responsável por $32 \%$ das exportações brasileiras, considerando-se como principais produtos exportados suco de laranja (US\$1 bi), café (US\$2,8 bi) e soja (US\$2,5 bi). A cobertura positiva dada ao modelo de agricultura baseado em monocultivos extensivos se mantém como uma marca do discurso oficial. Este tipo de visão fica explícito, por exemplo, em uma entrevista com o então Presidente da Embrapa, Eliseu Alves, em defesa da utilização de insumos químicos:

O desafio de manter a produção sem agrotóxicos - A chamada agricultura orgânica representa um retorno à forma de cultivo existente no Brasil até 1940. Essa concepção de forma de produzir, que pretende isolar a agricultura do setor industrial, através da rejeição do emprego de qualquer produto químico, não é viável num país como o Brasil, que precisa alimentar 130 milhões de habitantes (Gazeta Mercantil, 15/01/1985, p.11).

Esta citação resume a ideologia que defende o sistema que passou a ser conhecido mais recentemente como "agronegócio". O discurso que coloca em dúvida a "viabilidade" da produção de alimentos com base em um modelo diversificado serve como justificativa para a continuidade da subvenção da agricultura intensiva em termos 
de sua dependência de insumos industriais e, ao mesmo tempo, extensiva territorialmente.

Entretanto, as contradições geradas pelo processo de "industrialização" da agricultura mostram-se de forma mais evidente no decorrer da década de 1980, que é marcada pela chamada "crise da dívida" no Brasil e em outros países da América Latina. È importante notar que naquele período a defesa dos processos de renegociação e de moratória das dívidas era comum. Por exemplo, uma matéria de primeira página publicada no dia 15 de janeiro de 1985 comemora: "Rolagem da dívida até o ano 2000 Renegociação da dívida externa brasileira é a maior já feita pelo sistema financeiro internacional - são US $\$ 43,5$ bi de amortizações que serão negociados". Neste mesmo dia, o editorial anuncia: "Começa hoje a Nova República - Hoje é um daqueles dias em que as nações têm quase que a percepção física de que estão virando uma página da sua História" (Gazeta Mercantil, 15/01/1985, p. 1).

A cobertura sobre o tema da dívida externa dá destaque à necessidade de processos de renegociação. Em 1 de março de 1985 o jornal anuncia na primeira página a "Renegociação da dívida com os Estados Unidos". O Brasil já havia renegociado sua dívida com Clube de Paris. Em 12 de março, também com destaque na primeira página, o jornal traz a seguinte notícia: "México assina com os bancos - Reescalonamento de US\$49 bilhões com bancos credores (...) considerada a maior operação de refinanciamento efetuada até hoje". O tema é novamente manchete no dia 8 de junho de 1985, quando o editorial afirma:

Em um momento em que o país está empenhado na fase três da renegociação da dívida externa, é significativo o editorial da revista britânica The Economist exortando os bancos internacionais a uma atitude de boa vontade para com o novo presidente brasileiro que será oficialmente escolhido no próximo dia 15 (Gazeta Mercantil 08/06/1985, p. 3).

Todavia, com o agravamento da crise da dívida, os artigos de opinião passam a defender mais abertamente políticas baseadas no receituário do Fundo Monetário Internacional (FMI), conhecidas como medidas de "ajuste estrutural". O editorial de 25 de janeiro de 1985 segue a fórmula do discurso neoliberal, porém contendo ainda um tom nacionalista em defesa do papel do Estado como regulador da economia através do déficit público, que marcou as décadas anteriores:

Condicionantes de redução do déficit público - O governo está tentando novamente reduzir o déficit público (...). O objetivo básico dessa atitude é, 
naturalmente, mostrar ao FMI que ele não pretende continuar a desastrosa política do ano passado (...) O governo deve tomar medidas sem perder de vista aspectos negativos e perigosos, que uma contenção impensada do déficit pode gerar. E lembrar ao FMI que os credores que nos aconselham uma política de austeridade, deveriam preocupar-se também com os astronômicos déficits de seus próprios países (...) O déficit publico é uma forma, legitima ou não, mas viável, de manter parcelas significativas da população em um nível de vida razoável (Gazeta Mercantil, 25/01/1985, p. 3).

Naquele período, fica claro também que os produtores de açúcar acumulavam enormes dívidas com o Estado, principalmente com o Instituto do Açúcar e do Álcool (IAA), que garantia subsídios para o setor. Uma reportagem publicada no dia 8 Março mostra estes números: "Dívidas de usinas junto ao IAA chega a US\$720 milhões - O endividamento de apenas cinco empresas do setor açucareiro - as cooperativas de produtores de açúcar e álcool dos estados do RJ, SP, PE e AL, e mais o Grupo Atala já ascende a US\$720 milhões" (p. 22). Outra matéria que revela a crise no setor denuncia que a mudança na direção do Instituto do Açúcar e do Álcool pode ter sido ocasionada por irregularidades financeiras:

Confirmado Vilela no IAA - José Vilela, presidente do IAA anunciou auditoria externa para apurar eventuais irregularidades na gestão passada. (...) O IAA avalizou créditos no valor de US\$761 milhões às usinas de açúcar que contraíram empréstimos em cruzeiros e em moeda externa. Embora exigisse garantias dos usineiros, o IAA jamais executou os empréstimos (Gazeta Mercantil, 21/03/1985, p. 18).

Além da falência de muitas usinas de produção de açúcar e álcool, outras commodities agrícolas tiveram seus preços rebaixados no mercado internacional. A preocupação com a crise nas exportações agrícolas brasileiras é expressa na manchete de primeira página publicada no dia 12 de março: “Queda na exportação - principais produtos agrícolas que o Brasil exporta: queda na receita do café, açúcar, suco de laranja, cacau, soja e derivados”. Em resposta a esta situação, o governo anuncia um enorme volume de recursos para viabilizar as exportações: "Comercialização da safra precisa de Cr8,5 trilhões - O Ministro da Agricultura estima em Cr8,5 tri a necessidade de recursos para viabilizar a comercialização da safra de grãos e a formação de estoques reguladores" (Gazeta Mercantil, 21/03/1985, p. 18).

Apesar de historicamente o modelo agrícola brasileiro ter priorizado o monocultivo para exportação, naquele período o discurso oficial procurava enfatizar a necessidade de garantir acesso à alimentação para o mercado interno. A produção de alimentos a baixo custo visava apoiar setores industriais como forma de baratear a 
reprodução da força de trabalho. Uma entrevista com o então Ministro da Agricultura, Pedro Simon, expressa tal posição:

Simon quer apoio dos produtores para elevar a oferta de alimentos - A hora é grave. Sabemos que o povo, na sua ansiedade, espera mais do que pode ser dado. Sabemos que as desilusões serão muitas e nos atingirão, mas não é desse desafio que haveremos de fugir. Não teremos justiça social se não tivermos pão na mesa de todos os brasileiros. (...) É essencial criar um mercado consumidor para impulsionar a produção, o que será alcançado com o fim do arrocho salarial (Gazeta Mercantil, 16/03/1985 p. 18).

A crise financeira internacional, que aparece no Brasil como crise da dívida, estimula o debate sobre o modelo agrícola. Como constatamos anteriormente, o discurso oficial neste momento oscila entre a defesa da necessidade de conter o aumento do preço dos alimentos no mercado interno e as supostas vantagens da grande exploração agrícola para exportação. Em um artigo de opinião, o então assessor da Secretaria de Agricultura de São Paulo, Francisco Pereira, critica a permanência da concentração fundiária e os benefícios estatais concedidos à agricultura extensiva:

A velha e concentrada estrutura agrária do Nordeste: De 1970 a 1980, o café, a soja, a cana-de-açúcar, o algodão e o feijão receberam $60 \%$ do crédito rural. (...) A velha estrutura agrária, mesmo quando se moderniza, conserva seus elementos fundamentais: a forte concentração fundiária e o alto grau de exploração da força de trabalho (Gazeta Mercantil, 08/06/1985, p.4).

Aquele período foi caracterizado pela transição política de "redemocratização" do país, o que estimulou a expectativa de que se poderia avançar em um programa de reforma agrária. De fato, o Plano Nacional de Reforma Agrária (PNRA) foi anunciado, como destaca uma reportagem publicada em 29 de junho. Porém, a mesma matéria revela a pressão exercida pelos ruralistas para impedir a implantação de políticas distributivas no campo, com a seguinte manchete: "Reforma Agrária - Produtores consideram plano coletivista". A preocupação expressa pela Confederação Nacional da Agricultura (CNA) com o PNRA teria como justificativa a "forma de apropriação comunitária da terra”. Seguindo a mesma linha, o jornal cita também a opinião do presidente da Sociedade Rural Brasileira na época, Flavio Telles de Menezes: "Este plano não pode ter somente uma visão social, ele precisa ter uma visão econômica. Somos o lado econômico e, por essa razão, precisamos participar dessa discussão" (p. 15). Este trecho é emblemático porque repete uma ideia comumente disseminada por entidades ruralistas, que se autoclassificam como setor "econômico", o que implica dizer que a pequena agricultura teria um caráter estritamente "social". 
A manchete publicada na Gazeta Mercantil no dia 10 de julho de 1985 mostra a preocupação dos ruralistas em expressar um discurso nacionalista: "Agropecuária produtores fazem pacto para defender uma política agrária nacional" (p. 14). Ao se referir a tal política os ruralistas defendem, na verdade, a manutenção do modelo de monocultivo extensivo voltado preferencialmente para exportação. A análise deste tipo de discurso nos leva a constatar que certos jargões se repetem entre representantes do agronegócio. Por exemplo, a ideia de que este sistema seria "eficiente" e gerador de "desenvolvimento" econômico. Além destes argumentos, as exportações agrícolas eram estimuladas como suposta solução para saldar a dívida externa brasileira.

O debate ideológico não era a única arma dos ruralistas. Em reação às pressões sociais exercidas naquele período, que geravam a expectativa de realização da reforma agrária, verificam-se reações violentas por parte do latifúndio através da ação de grupos armados no campo. Uma entrevista com o então Ministro da Reforma e do Desenvolvimento Agrário, Nelson Ribeiro, demonstra tal preocupação:

Milícias armadas não impedirão desapropriações de terra, diz Ribeiro - Não podemos mais aceitar a atual estrutura agrária brasileira. (...) $\mathrm{O}$ alto grau de concentração de terra em latifúndios improdutivos representa um sério entrave à modernização agrícola. Em 1984 se constatava a existência de 10,6 milhões de trabalhadores sem-terra ou com pouca terra. (...) O governo não tenciona retirar populações sem terra de seu estado par localiza-las em outro. (...) Isso desagrega a estrutura familiar. Vamos buscar terras para ocupação no próprio local de residência do lavrador. (Gazeta Mercantil, 18/06/1985, p. 14).

Esta afirmação visa contestar críticas à política conhecida como "colonização", adotada durante o regime militar, que promoveu a migração de camponeses sem terra de outras regiões para a Amazônia. É interessante notar também que o Ministro defende a reforma agrária como meio de promover a "modernização agrícola", em contraposição à “concentração de terra em latifúndios improdutivos". Verificamos que, mais recentemente, o conceito de agronegócio serviu para modificar a imagem do latifúndio, no sentido de dar uma conotação positiva de modernidade à grande exploração agrícola que anteriormente era considerada atrasada.

A transição política que ocorria ao final da década de 1980 propiciou o fortalecimento de movimentos sociais rurais que demandavam a realização da reforma agrária. A ascensão das lutas sociais era vista com preocupação por setores do governo, que entendiam a necessidade de mudanças na estrutura agrária brasileira como forma de evitar maior grau de violência no campo. A seguinte manchete retrata esta situação: 
Reforma agrária: Richa propõe elaboração de plano emergencial para áreas de conflito - O governador José Richa, do Paraná, propôs que, paralelamente ao PNRA, o governo da Nova Republica comece, desde já, a elaborar um projeto emergencial de assentamento de famílias em regiões onde as disputas pela terra estejam próximas a transformar-se em conflitos. Richa voltou a criticar a morosidade com que o Ministério da Reforma e Desenvolvimento Agrário (Mirad) vem trabalhando (Gazeta Mercantil, 10/12/1985, p. 15).

O Paraná era palco de grandes mobilizações por acesso a terra, como mostra a reportagem a seguir:

Propriedades invadidas no Paraná - Mais de 800 famílias de sem terras decidiram não aguardar mais pelo plano de reforma agrária do governo e invadiram cinco propriedades, exigindo imediato assentamento. Em declarações anteriores, Richa afirmava que em hipótese alguma aceitaria invasões de terras e as famílias que delas participassem não seriam contempladas com a reforma agrária no estado (Gazeta Mercantil,17/12/1985, p. 14).

As declarações do então governador do Paraná mostram que a ideia de punir as famílias que participassem de ocupações de terra com o impedimento do seu ingresso no programa de reforma agrária já estava presente nas esferas governamentais. A matéria revela ainda que os ruralistas estruturaram novas organizações em resposta direta ao PNRA. O caso desta ocupação de terra foi emblemático, pois a fazenda pertencia ao presidente da Sociedade Rural do Paraná que, segundo o jornal, foi "criada por latifundiários depois que o plano de reforma agrária foi anunciado pelo governo". A nova entidade serviria também para garantir a continuidade dos subsídios estatais ao latifúndio e o perdão de dívidas anteriores: "Sociedade Rural não acredita em estimulo sem perdão de dívidas", diz a manchete da reportagem publicada em 20 de dezembro de 1985 (p.18). Esta afirmação demonstra que os próprios ruralistas reconheciam a inviabilidade econômica de suas atividades.

Ao término de 1985, a conjuntura política do país refletia os efeitos do final da ditadura militar e da morte de Tancredo Neves. O então presidente José Sarney buscava um tom conciliador no campo da política interna, ao mesmo tempo em que o tema da dívida externa prevalecia no cenário latino-americano. A manchete de primeira página da Gazeta Mercantil em 30 de novembro descreve este contexto: "Distorções ameaçam a economia - A procura de formas mais justas de pagamento da divida externa, a defesa do regime democrático e a integração econômica binacional foram os temas dominantes nos discursos dos presidentes José Sarney, do Brasil, e Raúl Alfonsin, da Argentina”. Em relação à política agrícola, o jornal mostra que as propostas do governo incluíam 
maior controle sobre estoques e importações programadas de alimentos para abastecer o mercado interno:

O que muda na política de abastecimento - Contabilizas as perdas da safra de alimentos, comprometida pela seca (...). Montar programa de importação de alimentos necessários. Comprar no exterior o que for preciso, nos momentos necessários. Garantir estoques de alimentos e melhorar o sistema de transporte interno (Gazeta Mercantil, 30/11/1985, p. 1).

Em relação ao cenário internacional observa-se que o discurso representado no jornal passa a defender mais abertamente políticas de abertura comercial. Porém, como percebemos até a atualidade, a política que prevalece nos países centrais é de proteção estatal à indústria e à agricultura, enquanto negociam acordos de "livre" comércio com países periféricos. O texto editorial a seguir revela tal debate:

O protecionismo e a evolução do comércio mundial - $\mathrm{O}$ presidente Ronald Reagan corroborou a firme disposição anti-protecionista de seu governo ao vetar o projeto aprovado pelo Congresso criando novas restrições, pelos EUA, de produtos têxteis, de calçados e de artefatos de cobre (...). Apesar dos óbvios benefícios para o consumidor americano da importação de produtos baratos e de boa qualidade, fabricados em países em desenvolvimento, a força dos lobbies das indústrias locais é ainda muito intensa, recusando-se a aceitar o que pode ser considerado como uma evolução irreversível do comércio mundial (Gazeta Mercantil, 21/12/1985, p. 4).

A administração de Ronald Reagan nos Estados Unidos aprofunda os efeitos das políticas denominadas neoliberais, que pregavam a defesa do Estado mínimo e o corte orçamentário de programas sociais. Porém, durante o período considerado neoliberal, observa-se a manutenção do financiamento estatal para grandes empresas, enquanto se desmonta políticas de bem-estar social (Welfare State). Portanto, o Estado nunca foi mínimo para o capital.

Ao final da década de 1980, o contexto político no Brasil é marcado pelos efeitos da crise da dívida, que estimulam argumentos sobre a necessidade de enxugamento do Estado, como suposta solução para o endividamento. A agricultura voltada para exportação, altamente dependente de financiamento estatal, é fortemente afetada pela crise, como demonstra a manchete de primeira página:

Pouca esperança nos preços dos grãos - A retomada no desenvolvimento do setor agrícola em 1990, freada no último ano pela implosão no sistema de crédito rural e pela mais drástica escassez de recursos já enfrentada pelo campo, não encontrará no mercado um forte aliado. Para muitos dos produtos de exportação, as perspectivas de mercado são desfavoráveis e incompatíveis com a elevação dos custos financeiros de produção (Gazeta Mercantil, 30/12/1989, p. 1). 
Na mesma edição, o texto editorial descreve aquele momento político, que consideramos significativo no sentido de distinguir o início da prevalência de políticas neoliberais no Brasil. Tais políticas são caracterizadas pelas chamadas reformas estruturais, justificadas da seguinte forma:

O mundo verifica uma das maiores transformações por que já passou. Terminou a política da "guerra fria", os países do Leste europeu iniciaram, de uma maneira inesperada, uma rápida marcha para a liberdade (...). O Brasil em 89 não ficou fora das mudanças. No campo econômico sepultaram-se com o fracasso do Plano Verão muitas das idéias que procuraram explicar por muitos anos o sentido da crise brasileira. Reforçou-se, por outro lado, a idéia das reformas estruturais (Gazeta Mercantil, 30/12/1989 p. 4).

È interessante notar que a defesa de políticas neoliberais ganha força em âmbito internacional a partir do evento descrito como o "fim da guerra fria". Este momento se caracteriza pelo colapso econômico da União Soviética e é celebrado como se representasse uma vitória do capital sobre o Estado, como observamos no editorial que propõe a "necessidade de construirmos um novo Estado, com uma máquina pública mais ágil e eficaz" (Gazeta Mercantil, 30/12/1989 p. 4).

A mesma edição do jornal celebra a primeira eleição presidencial no Brasil depois que quase três décadas de ditadura militar: "Depois de 29 anos realizamos a mais ampla eleição para presidente que este país já viu. Elegemos um presidente sob a égide da paz e da tranqüilidade" (Gazeta Mercantil, 30/12/1989 p. 4).

Em relação à política agrícola, a Gazeta Mercantil passa a adotar o termo commodities com mais frequência a partir daquele período, reservando três páginas com esse título, que incluíam matérias sobre produção agropecuária e também sobre mineração. O jornal introduz ainda uma página sob o título de "meio ambiente". Na edição de 30 de dezembro de 1989, a página que trata do tema commodities destaca transformações no comércio internacional de café, iniciando o uso do termo "mercado livre" que segundo a reportagem:

(...) provocou queda de $50 \%$ nos preços e poderá reduzir plantio - $\mathrm{O}$ setor cafeeiro, em 1989, viveu um ano histórico. O rompimento das cláusulas econômicas do Acordo Internacional do Café (AIC), no último dia 3 de julho, instalou o mercado livre, estabelecendo uma competição acirrada entre os países produtores. Imediatamente os estoques existentes no mundo foram colocados em oferta e os preços internacionais caíram até $50 \%$ (...) No regime de liberdade de mercado, o preço médio do café brasileiro teve uma perda de 43,9\% (Gazeta Mercantil, 30/12/1989, p.19). 
Apesar dos números negativos apresentados acima, o início da década de 1990 sinaliza claramente uma mudança de discurso no jornal, que anteriormente destacava a importância do papel do Estado nas políticas agrícolas e passa a defender a ideia de livre comércio como benéfica para a agricultura. Entretanto, é preciso observar que ao mesmo tempo em que o discurso hegemônico ressalta os supostos benefícios da liberdade de mercado, o apoio estatal para a agricultura extensiva nunca foi interrompido. Este modelo agrícola continua a ser apresentado como importante fonte de divisas para o equilíbrio da balança comercial no Brasil.

Naquela época a Gazeta Mercantil começa a reservar maior espaço também para matérias sobre as tendências dos mercados de futuro, o que demonstra a crescente influência que o capital financeiro passa a exercer sobre a agricultura. Os principais produtos brasileiros negociados nas bolsas de valores eram cacau, suco de laranja, café, açúcar e soja. Nas páginas sobre agropecuária, verificamos que as manchetes mais comuns tratavam de notícias sobre a cotação de commodities no mercado internacional e sobre condições climáticas.

Nos anos 1990 verifica-se uma mudança no movimento da balança comercial brasileira ocasionada pelo aumento da liberalização das importações de alimentos. Esta tendência é apresentada no editorial de 19 de janeiro de 1990, que anuncia:

O aumento das importações - O país fechou a década com fluxo de comércio internacional recorde, alcançando US\$52,673 bi, sendo que este crescimento teve a participação decisiva no aumento das importações feitas pelo Brasil no ano de 1989. O quadro nos sugere um movimento importante e correto, quer seja o aumento das importações tão necessárias à economia brasileira que, devido a um ajuste externo perverso receitado para o Brasil nos últimos anos, foi obrigado a conter as importações e exportar mais (...) para fazer caixa para o pagamento do serviço da dívida externa (Gazeta Mercantil, 19/01/1990, p. 4).

Este texto reflete o duplo discurso do jornal que, ao contrário de sua posição anterior, passa a considerar as importações agrícolas como benéficas para a economia brasileira. O editorial volta a mencionar o efeito da dívida externa, caracterizado como "ajuste perverso", no sentido de explicar a tendência de liberalização da economia. De acordo com o jornal, a crise permanece no setor sucroalcooleiro, como mostra a seguinte matéria:

Insolvências: Ministro é a favor de desapropriar Grupo Atalla - O Ministro da Justiça, Saulo Ramos, é favorável à desapropriação do patrimônio do Grupo Atalla, avaliado em mais de US\$1 bilhão. O grupo deve US\$170 milhões ao estado do Paraná e NCz\$800 milhões ao IAA (...) O Ministro da Justiça destaca 
que o Grupo Atalla é devedor costumeiro e não pode navegar nas águas da impunidade (Gazeta Mercantil 13/01/1990, p. 31).

Esta citação revela que a prática da rolagem do endividamento é comum nas usinas de cana. Também é interessante notar que o Ministro propõe a desapropriação da empresa pelo Estado. Porém, este tipo de opinião perde força na medida em que prevalece a hegemonia do discurso neoliberal, baseado na defesa do Estado "mínimo". Apesar da manutenção de subsídios estatais para grandes empresas agrícolas e industriais, o discurso neoliberal passa a dominar o meio político e jornalístico naquele período. O editorial que avalia o novo governo mostra a posição do jornal em favor de políticas de "ajustamento do Estado":

Límpida postura política - A postura política do presidente eleito Fernando Collor de Mello, na delicada fase que precede a sua posse, tem primado pela coerência e limpidez (...). O presidente eleito está se comportando com absoluta lisura e discrição (...) O novo problema hoje é a gestão financeira do Estado (...) a sociedade brasileira exige do governo exemplos, ações e atitudes efetivas que demonstrem claramente que o problema de ajustamento começa pelo próprio Estado" (Gazeta Mercantil, 13/01/1990, p. 4).

Poucos dias depois, em 30 de janeiro, o texto editorial expressa uma posição semelhante, desta vez em apoio a uma reforma fiscal com o objetivo de sanear as finanças do Estado: "Restaurar a credibilidade - Os responsáveis pela política econômica estão preocupados com graves ameaças ao controle do déficit público no exercício de 1990 (...) O programa de Collor prevê uma reforma fiscal como indispensável para o saneamento financeiro do Estado" (p. 4). A mesma edição do jornal apresenta uma desconexão entre a defesa do "enxugamento" do Estado e o discurso que visa legitimar os subsídios estatais para a agricultura extensiva, como mostra a seguinte matéria:

Crédito rural - Produtor busca recursos com bancos privados - Na opinião de Roberto Rodrigues (presidente da Organização das Cooperativas Brasileiras) a insuficiência de crédito à comercialização cuja probabilidade atinge US $\$ 8$ bilhões conta com uma demanda estimada de US\$15 bilhões (Gazeta Mercantil, 30/01/1990, p. 19).

$\mathrm{O}$ discurso em defesa da necessidade de se realizar reformas do Estado vem acompanhado do argumento que avalia tais reformas como meios de resolver a crise da dívida externa. Este tipo de linguagem é encontrado, por exemplo, no editorial de 1 de dezembro de 1990, que expressa:

Apoio para a negociação da dívida em contrapartida à política de abertura - $\mathrm{O}$ governo brasileiro está pedindo à comunidade internacional, mais 
especificamente aos EUA, que sua política de abertura econômica seja reconhecida (...). Espera que tal reconhecimento seja manifestado em ações como negociação da dívida externa com credores privados e contrapartidas para as reduções tarifárias que vem promovendo (Gazeta Mercantil, 01/12/1990, p. 4).

Mas na medida em que avança a receita neoliberal, baseada nas políticas de privatização de serviços públicos, a chamada crise da dívida viria a se agravar, como mostra o seguinte texto editorial:

Por um novo começo - Estamos vindo de um período em que uma injusta divisão internacional do trabalho provocou uma profunda deteriorização de nossas contas externas, ao mesmo tempo que financiava a prosperidade do mundo desenvolvido durante a década de 80 (...) O presidente George Bush é aquele homem que foi capaz de fazer o discurso memorável em que propôs a criação de um bloco econômico panamericano e o conseguinte entendimento continental (...) O governo Collor desenvolveu uma política de abertura comercial que alterou sensivelmente o panorama (...) Em pouquíssimo tempo nosso saldo comercial se foi, o que potencialmente nos impedirá, no futuro, mantida essa política, de pagar o serviço da dívida (...) pagamos US\$80 bi em juros em oito anos e, além de tudo, ainda somos considerados maus pagadores (Gazeta Mercantil, 04/12/1990, p. 4).

Apesar de reconhecer a situação de crise econômica, o jornal continua a exaltar políticas de abertura comercial aplicadas pelo então presidente Fernando Collor no Brasil e por George Bush nos Estados Unidos, que aprofundaram a crise. A linha editorial mantém a defesa da ideia de Estado mínimo. Neste mesmo período, diversos artigos da Gazeta Mercantil transmitem uma imagem positiva sobre o processo de concentração do capital privado, expresso na formação de grandes monopólios ou joint ventures. A manchete de primeira página do dia 1 de dezembro de 1990 aborda este tema:

Dificuldades para investir no Brasil - A Mitsubishi Corp., o gigantesco grupo japonês com um volume anual de negócios de cerca de US\$ 150 bi estava em meio à discussão de um novo investimento no Brasil, uma joint venture na área agrícola, quando o governo decidiu suspender a remessa de dividendos das empresas estrangeiras, no inicio deste ano (Gazeta Mercantil, 01/12/1990, p. 1).

Nas edições posteriores do jornal, a página com o título "Agropecuária" é substituída por uma seção intitulada "Mercados / Commodities". Grande parte do conteúdo das matérias se limita a acompanhar as oscilações dos preços das commodities no mercado internacional e a avaliar o impacto de condições climáticas na produção agrícola. Artigos sobre temas como reforma agrária e agricultura local praticamente somem do noticiário. 
As consequências sociais e econômicas da crise que se instalou no Brasil durante os anos de 1980, conhecidos como a década perdida podem ser verificadas nos registros jornalísticos. Este período foi marcado pelo início da implantação de políticas neoliberais, tanto no meio rural quanto urbano. No campo brasileiro, tais políticas aprofundaram a constituição de monopólios privados que formaram o chamado complexo agroindustrial, mantendo a concentração fundiária e o poder dos latifúndios. O êxodo rural causou enorme impacto nas cidades e tornou-se notícia frequente, como mostra a seguinte reportagem:

Seis milhões ganham um quarto do salário mínimo nas metrópoles - Os pobres brasileiros concentram-se nas cidades. Este fenômeno mais recente de concentração de renda no país vem sendo conhecido como 'metropolização da pobreza', e poderá agravar-se de maneira perigosa na década de 90 (Gazeta Mercantil, 1 de dezembro de 1990, p. 3).

Em relação à conjuntura internacional, um dos temas mais frequentes naquela ocasião era o acompanhamento das negociações dos acordos de livre comércio, principalmente o GATT (General Agreement on Trade and Tariffs). A ideia central abordada neste contexto é de que a liberalização comercial serviria como saída para a crise da dívida. Além do GATT, outras propostas de acordos comerciais de países latino-americanos com a Europa e os Estados Unidos estavam em fase inicial:

Latinos querem acordos para zonas de livre comércio com os europeus - Oito ministros de finanças de países latino-americanos decidiram pedir à Comunidade Econômica Europeia (CEE) um plano semelhante ao do presidente George Bush para criar uma zona de livre comércio nas Américas. (...) O plano inclui também uma proposta para reduzir a dívida externa da América Latina de US $\$ 410$ bi e para incentivar investimentos na região (Gazeta Mercantil, 4/12/1990, p. 2).

Como veremos no capítulo a seguir, o tema da agricultura passa a ser central neste tipo de negociação comercial. No primeiro ano da década de 1990, se repetiam os argumentos de que a abertura comercial e as políticas de privatização de empresas estatais nos países periféricos seriam "recompensadas" pelos credores externos, como no trecho do seguinte editorial:

Da esperança à prosperidade - $\mathrm{O}$ presidente Bush considerou condição imprescindível a retirada da 'mão morta do controle estatal' e conclamou ‘a 'inabalável convicção quanto à importância e os benefícios da livre iniciativa'. Aqui, pode-se assegurar, nada ocorrerá se os agentes econômicos privados não souberem reconhecer os movimentos de desestatização e desregulamentação promovidos por diversos países do continente, entre os quais o Brasil (Gazeta Mercantil, 4/12/1990, p. 4). 
Este tipo de argumentação se intensificará no decorrer da década de 1990. Os meios de comunicação continuarão a disseminar a defesa do livre comércio e do Estado mínimo, ao mesmo tempo em que se mantêm mecanismos estatais de subsídios para setores empresariais. No caso do complexo agroindustrial, sua própria estruturação e posterior fortalecimento só foram possíveis através da intervenção estatal, como explica Delgado (2012):

O Sistema Nacional de Crédito Rural (SNCR), implantado a partir de 1965 com a Lei do Crédito Rural (lei no 4829 de 5/11/65) é a base principal sobre a qual se apoia a modernização técnica da agricultura brasileira. Esse sistema, desde sua origem até o presente, tem funcionado com diferentes arranjos de engenharia financeira, que em última instância reciclam recursos financeiros públicos e privados para aplicação nas atividades do setor rural, designados normativamente. Essas aplicações estão sujeitas à redução significativa de juros e de outras condições favoráveis, relativamente às condições do crédito bancário geral (DELGADO, 2012, cap. 5).

Esta citação explica o fundamento sobre o qual se constituiu o chamado agronegócio no Brasil, com a concessão de linhas especiais de crédito subsidiado, políticas de favorecimento comercial para commodities agrícolas, manutenção de grandes extensões de terras em poder de oligarquias rurais e acesso à infraestrutura, como veremos em mais detalhes no capítulo seguinte. 


\section{Capítulo 5 - O Conceito de Agronegócio no Brasil}

\section{$\underline{\text { A concepcão das chamadas cadeias produtivas na agricultura }}$}

No Brasil, o termo agronegócio, compreendido como o processo de industrialização da agricultura, tem sido utilizado para justificar a criação das chamadas cadeias produtivas, com o objetivo de agregar atividades agroquímicas, industriais e comerciais aos cálculos econômicos da agricultura. Este conceito é definido por Marcos Sawaya Jank, um dos ideólogos do setor, como:

O agronegócio nada mais é do que um marco conceitual que delimita os sistemas integrados de produção de alimentos, fibras e biomassa, operando desde o melhoramento genético até o produto final, no qual todos os agentes que se propõem a produzir matérias-primas agropecuárias devem fatalmente se inserir, sejam eles pequenos ou grandes produtores, agricultores familiares ou patronais, fazendeiros ou assentados (O Estado de São Paulo, 05/07/2005 ${ }^{63}$ ).

A ideia de que todos os segmentos sociais do campo brasileiro deveriam "fatalmente se inserir" neste modo de produção sugere que o autor vê este processo como uma fatalidade, ou seja, como um movimento natural e irreversível. Tal observação nos leva à necessidade de investigar o contexto das relações sociais no qual o conceito de agronegócio é construído e disseminado.

As contradições que marcam a dinâmica própria do modo capitalista de produção no Brasil têm sua origem histórica no período de colonização e, portanto, não constituem um processo natural ou inevitável. As características de monopólio da terra e de uma política agrícola voltada preferencialmente para o mercado externo obviamente não são novas. Caio Prado Jr. observa este ponto quando concebe o papel do Brasil colonial como país-empresa, fornecedor de produtos agrícolas e minerais para a Europa, no contexto capitalista. O autor explica que:

Se vamos à essência da nossa formação, veremos que na realidade nos constituímos para fornecer açúcar, tabaco, alguns outros gêneros; mais tarde, ouro e diamante; depois algodão e, em seguida, café para o comércio europeu. (...) Este início, cujo caráter manter-se-á dominante através dos séculos da

\footnotetext{
${ }^{63}$ Este artigo foi publicado no jornal O Estado de São Paulo em 05/07/2005 e está disponível também no sítio web do Ministério de Relações Exteriores, o que indica a influência deste pensamento no governo brasileiro. O acesso pode ser feito através do link: http://www.mre.gov.br/portugues/noticiario/nacional/selecao_detalhe3.asp?ID_RESENHA=146 329. Consulta em 20/01/2009.
} 
formação brasileira, gravar-se-á profunda e totalmente nas feições e na vida do país. Particularmente na sua estrutura econômica. E prolongar-se-á até nossos dias (PRADO Jr., 1970, p. 23).

É possível identificar tais elementos na política agrícola brasileira, que prioriza incentivos para a exportação de commodities agrícolas e minerais, desde o período colonial até a atualidade, quando se elabora a definição do chamado agronegócio. Ao analisarmos a adoção do conceito que ficou conhecido primeiramente como agribusiness no Brasil, percebemos que está baseado em uma perspectiva que adota a ideia de desenvolvimento como sinônimo de progresso tecnológico, que ocorre em etapas. Tal visão está presente na definição do que seriam as chamadas cadeias produtivas.

Em seu artigo Cadeias Produtivas e Complexos Industriais (2002) ${ }^{64}$ Victor Prochnik define cadeia produtiva como um "conjunto de etapas consecutivas", formado basicamente por três etapas: "extração, transformação e montagem". Para o autor, este conceito passou a ser necessário para responder a um "aumento das economias de escala e escopo das empresas" (Prochnik, 2002, p. 6).

A concepção de cadeia produtiva foi utilizada por ideólogos do agronegócio que atuam no Programa de Estudos dos Negócios do Sistema Agroindustrial (Pensa), da Universidade de São Paulo, para definir um método próprio de quantificação econômica dos Sistemas Agroindustriais (SAGs). Este método agrupa todas em empresas envolvidas nos setores de insumos (agrotóxicos, fertilizantes, sementes, máquinas agrícolas), agricultura, indústria de alimentos e fibras, distribuição por atacado e varejo, além de empresas de embalagens, transporte, combustíveis, armazenamento, concessionárias de rodovias e serviços portuários, para chegar ao que representaria o Produto Interno Bruto (PIB) do agronegócio (NEVES, 2005, p. 26-31).

O conceito de cadeia produtiva também foi adotado como referência metodológica para definir políticas públicas na Embrapa, de acordo com o artigo Cadeia Produtiva: Marco Conceitual para Apoiar a Prospecção Tecnológica (2002) 65

\footnotetext{
${ }^{64} \mathrm{http}: / /$ www.ie.ufrj.br/cadeiasprodutivas/pdfs/cadeias_produtivas_e_complexos_industriais.pdf (consulta em 28/07/11).

${ }^{65} \mathrm{http} / / /$ www.pee.mdic.gov.br/portalmdic/arquivos/dwnl_1197031881.pdf (consulta em 28/07/11).
} 
de Antônio Maria Gomes de Castro, Suzana Maria Valle Lima e Carlos Manuel Pedroso Neves Cristo. Os autores argumentam que "O conceito de cadeia produtiva é de natureza holística, e foi desenvolvido como instrumento de visão sistêmica" com o objetivo de "apoiar prospecção tecnológica". A ideia de "visão sistêmica" significa que "os diversos atores estão interconectados por fluxos de materiais, de capital e de informação, objetivando suprir um mercado consumidor final com os produtos do sistema" (Castro; Lima; Cristo, 2004, p. 1-2). As cadeias produtivas são descritas como "subsistemas" de um "sistema" mais amplo, denominado de agronegócio.

Segundo o texto, a Embrapa incorporou esta perspectiva a partir dos anos 1990 para incluir como "clientes" setores denominados "de fora da porteira da fazenda", mais especificamente empresas de insumos químicos, industriais, de infraestrutura e de comercialização agrícola. Os autores mencionam que essa estratégia foi adotada com base no pensamento de Davis e Goldberg (1957) em seu livro The Concept of Agribusiness e que passou a ser utilizada no Brasil inicialmente através da concepção de complexo agroindustrial, de negócio agrícola e, mais recentemente, de agronegócio (Castro; Lima; Cristo, 2004, p. 6).

A definição de cadeia produtiva tem origem no termo filière, em francês. Uma das características deste sistema seria abranger "ao mesmo tempo, a concentração do poder e a descentralização das tarefas produtivas e dos serviços". Essa descentralização é caracterizada através da implantação das chamadas "parcerias produtivas", nas quais "os diferentes atores organizam-se de forma hierárquica" (...) que "traduzem-se em relações de dominação/subordinação". Para Favero, essa subordinação seria positiva, já que ocorreria em consequência da necessidade de garantir qualidade dos produtos e de massificar a produção, no sentido de "aumentar a capacidade de competição de determinados atores em um mercado cada vez mais exigente e globalizado". De acordo com tal perspectiva, este tipo de subordinação teria o papel de garantir "regularidade" nos mercados mundiais e, por essa razão, este modelo teria "um disciplinamento rigoroso das relações entre as indústrias e os agricultores" (FAVERO, 1996, p. 281282).

Além de criar uma imagem de harmonia, eficiência e disciplinamento para o sistema que seria propagandeado como agronegócio, a definição de cadeia produtiva se originou com o propósito de justificar a articulação ou interdependência de pequenos 
agricultores com grandes empresas e de setores agrícolas e industriais. Entretanto, esta concepção passou a ser aplicada também por setores puramente industriais, o que significaria "eliminar o elo propriedade agrícola". Os autores explicam este processo como uma "evolução na direção da universalização do conceito", a partir de uma metodologia descrita como "visão sistêmica" (Castro; Lima; Cristo, 2004, p. 8-9). A adoção deste tipo de política pela Embrapa está inserida em um contexto mais amplo de fortalecimento de um modo de produção agrícola disseminado sob o slogan de revolução verde.

A revolução verde passou a ser difundida mundialmente a partir dos anos 1950. No Brasil, a principal mudança ocorrida na agricultura foi a substituição de uma base essencialmente orgânica por técnicas dependentes de insumos químicos e industriais. Kageyama (1987) descreve a origem deste processo a partir da transformação dos complexos rurais, voltados para o mercado externo e caracterizados principalmente pelos ciclos da cana e do café, que passaram a ser caracterizados como complexos agroindustriais. A autora analisa dados comparativos sobre o papel de produtos industriais na agricultura brasileira, que representavam $10 \%$ do custo de produção em 1949, passaram a 25\% no final da década de 1960 e chegaram a 40\% em 1980. O maior índice de elevação ocorre em 1965, quando houve aumento de $7 \%$ em relação ao ano anterior. O uso de fertilizantes apresentou uma alta anual de $13 \%$ entre 1950 e 1985, sendo que de 1867 a 1980 a elevação chegou a 17\% ao ano (KAGEYAMA, 1987, p. 120-128).

Em relação à utilização de máquinas agrícolas, até 1920 o único setor que adotava algum tipo de mecanização no Brasil era a produção canavieira. A partir de 1940, a mecanização foi parcialmente adotada na produção de café em São Paulo e de trigo e arroz no Rio Grande do Sul. A mecanização em grande escala ocorre principalmente a partir de 1960, nas plantações de soja, estimulada por créditos subsidiados. Empresas estadunidenses e europeias exerciam controle do setor, mesmo quando a fabricação destes insumos era feita no Brasil, com a implantação de fábricas subsidiárias. O monopólio na produção de tratores era exercido por três empresas Massey Ferguson, Ford e Valmet; e a produção de colheitadeiras era controlada principalmente pela Massey, Schneider Logemann (SLC) e New Holland, que foi incorporada posteriormente pela Ford (KAGEYAMA, 1987 p. 149-150). 
Como parte do pacote tecnológico conhecido através da propaganda da revolução verde, os chamados "defensivos" agrícolas foram disseminados mundialmente a partir do período pós-guerra. No Brasil, estes produtos passam a ser utilizados mais intensamente a partir de 1961, quando o Ministério da Agricultura elimina barreiras à importação de insumos químicos. Entre 1974 e 1981 o crédito subsidiado para estes insumos cresceu em 213\%, o que representou uma alta proporcionalmente maior do que o crédito para custeio geral da agricultura, que teve um aumento de $92 \%$ no mesmo período. A alta no preço do petróleo refletiu de forma significativa neste custo. Na década de 1980, o Brasil ocupava o quarto lugar em consumo mundial de herbicidas, fungicidas e inseticidas, sendo o maior consumidor de agrotóxicos na América Latina (KAGEYAMA, 1987, p. 139-140).

A utilização desses produtos no Brasil ocorre de forma indiscriminada, principalmente porque os órgãos de fiscalização não exerciam um monitoramento efetivo em relação aos impactos ambientais e para a saúde pública. Outro problema relacionado à substituição de uma base orgânica por agroquímicos resultou da dependência dos agricultores a este tipo de insumo. A autora avalia que "o uso continuado de inseticidas e fungicidas não só levou ao aparecimento de fenômenos de resistência, mas à multiplicação das pragas” (KAGEYAMA, 1987, p. 141-147).

Kageyama observa que até a década de 1970 o comércio mundial de fertilizantes era controlado por empresas transacionais com sede principalmente nos Estados Unidos e Europa. A partir dos anos 1980, verifica-se o aprofundamento da formação de monopólios de diferentes setores do complexo agroindustrial através de fusões ou joint ventures. Tal mudança se concretiza com base no acesso destas empresas a políticas governamentais de crédito, o que propicia o aumento da concentração de capitais agrícolas, industriais e bancários. A integração desses capitais estimulou a especulação e o mercado de terras no Brasil, que se caracterizou pela aquisição de vastas áreas territoriais por grandes empresas nacionais e estrangeiras (KAGEYAMA,1987, p. 123).

\section{$\underline{\text { A visão neoliberal e o agronegócio }}$}

Durante o período marcado pela implantação de políticas neoliberais, difunde-se uma perspectiva sobre a situação do campo brasileiro, segundo a qual tanto o latifúndio quanto o campesinato tenderiam a se modernizar. Um dos defensores desta corrente é José Graziano da Silva (1997) que, em seu artigo O Novo Rural Brasileiro, afirma: 
“está cada vez mais difícil delimitar o que é rural e o que é urbano". O autor entende que "essa integração terminou por se consolidar nos chamados complexos agroindustriais que passaram a responder pela própria dinâmica das atividades agropecuárias aí vinculadas ${ }^{66,}$.

Tal pensamento prevaleceu durante o governo de Fernando Henrique Cardoso, que implantou um programa agrário denominado de novo mundo rural, que tinha como alicerce uma política fundiária voltada para a privatização do mercado de terras, em detrimento de um programa de reforma agrária. Este tipo de concepção foi fomentado pelo Banco Mundial através da criação dos programas Cédula da Terra, Banco da Terra e Crédito Fundiário. Apesar desta política se basear na ideologia neoliberal de Estado mínimo, o Banco Mundial exigia uma contrapartida dos governos para seus projetos, o que comprometia o orçamento do Estado para a reforma agrária (MARTINS, 2004).

É importante observar que toda a política governamental que prevaleceu durante o período chamado de neoliberal representou, na verdade, maior transferência de maisvalia social para o setor privado através do aparato estatal, como no caso das privatizações de setores estratégicos da economia brasileira. Portanto, o suposto Estado mínimo nunca existiu para o capital.

Naquele mesmo período, os ideólogos do agronegócio no Brasil passaram a utilizar o termo agricultura familiar para denominar sua visão de que pequenos agricultores deveriam fatalmente se integrar às chamadas cadeias produtivas do agronegócio. Marcos Jank (2005), por exemplo, afirma que existiria uma "falsa dicotomia que contraporia o agronegócio à agricultura familiar”. Jank reconhece o alto nível de produtividade da pequena agricultura e cita dados do Censo agropecuário de 2006, mostrando que esta "representa boa parte da produção agropecuária: $84 \%$ da farinha de mandioca, $97 \%$ do fumo, $67 \%$ do feijão, $58 \%$ da carne, $52 \%$ do leite, $49 \%$ do milho, $40 \%$ das aves e ovos, $32 \%$ da soja e $31 \%$ do arroz". Porém, o autor utiliza estes

\footnotetext{
${ }^{66}$ SILVA, José Graziano, O Novo Rural Brasileiro. Revista Nova Economia, Belo Horizonte, Vol. 7, n. 1, p.43-81, maio 1997.
} 
números para concluir que "A agricultura familiar é, portanto, apenas um segmento central do agronegócio ${ }^{67, "}$.

Seguindo esta mesma linha, Jank (2006) prega a "verticalização" da agricultura brasileira, combinada à noção de cadeia produtiva ou "coordenação vertical", em uma perspectiva futurista que prevê a crescente especialização da produção agrícola:

(...) o agricultor do futuro tende a ser cada vez mais um gerenciador de contratos complexos com indústrias fornecedoras de máquinas e insumos mecanização, agricultura de precisão, irrigação, biotecnologia, etc. Contratos complexos e maior coordenação vertical também marcarão as relações entre o varejo, a agroindústria processadora e os agricultores, em decorrência da pressão por novos atributos de qualidade e sanidade de produtos, classificação, etiquetagem, certificação e rastreabilidade, entre outros ${ }^{68}$.

De acordo com a citação acima, o problema para os chamados "agricultores familiares", que estariam destinados a subordinar-se ao agronegócio, seria sua dificuldade de adaptação a um sistema gerencial "complexo", que incluiria controles mais rígidos de "qualidade". Ou seja, o autor reduz a análise das relações sociais no modo capitalista de produção a meras questões técnicas.

Valter Israel da Silva, integrante do Movimento de Pequenos Agricultores (MPA), faz uma análise crítica deste tipo de ideologia e avalia que a difusão de políticas para "integrar" os camponeses ao agronegócio, a partir do conceito de agricultura familiar, foi central na constituição deste modelo agrícola. $\mathrm{O}$ autor explica que:

As principais características desta proposta são: a especialização, o monocultivo ou monoprodução, a tecnologia externa, a integração à indústria, o uso de mão de obra familiar, adubos químicos e venenos, gera dependência da indústria e lucro para as multinacionais. (...) É um sistema que permite o maior nível de exploração das famílias camponesas pelas indústrias, através da externalização dos custos. (...) Este projeto foi amplamente apoiado pelos últimos governos no Brasil. Foi criado todo um sistema que engloba pesquisa, educação, assistência técnica, política de créditos (SILVA, 2011, p. 3-4).

Este modelo, que inicialmente foi denominado de novo mundo rural, determina que a agricultura camponesa faça parte das chamadas parcerias produtivas com o

\footnotetext{
${ }^{67}$ Jank, Marcos S., Agronegócio versus agricultura familiar? O Estado de São Paulo, 05/07/2005, p. A2, http://www.milkpoint.com.br/cadeia-do-leite/comerciointernacional/agronegocio-versus-agricultura-familiar-24457n.aspx. Consulta em 15/03/2012.

${ }^{68}$ Jank, Marcos S., Políticas para o futuro da agricultura, O Estado de São Paulo, 6/12/2006, p. A2, http://textospra.blogspot.com/2006/12/165-polticas-para-o-futuro-da.html. Consulta em $2 / 03 / 2012$
} 
agronegócio. Tal perspectiva pode ser identificada no pensamento de Abramovay (1992), segundo o qual, é no período entre a Segunda Guerra Mundial e o início da década de 1970 que surge a chamada agricultura familiar integrada ao agronegócio. Segundo o autor, "a agricultura familiar é um fenômeno tão generalizado nos países capitalistas avançados que não pode ser explicada pela herança histórica camponesa (...) o Estado foi determinante na moldagem da atual estrutura social do capitalismo agrário". Em outro trecho deste texto, o papel da agricultura familiar é atribuído à necessidade de "permitir que o peso da alimentação na estrutura de consumo dos assalariados fosse cada vez menor e portanto que os orçamentos domésticos pudessem consagrar-se crescentemente à aquisição de bens duráveis" (ABRAMOVAY, 1992, p.21-23). O autor reconhece o papel do Estado como determinante na aplicação de medidas que favoreceriam a produção de alimentos pela chamada agricultura familiar. Porém, sua interpretação se limita a imaginar que tal política teria o propósito de massificar o consumo de produtos industriais. Ou seja, o foco da explicação se desloca para a relação de oferta e demanda, desconsiderando as contradições centrais que a reprodução da classe trabalhadora exerce no processo produtivo.

O papel da agricultura familiar e sua integração ao agronegócio são normalmente interpretados por ideólogos do setor de forma positivada, como se fossem fenômenos naturais. Este tipo de pensamento pode ser sintetizado na seguinte afirmação:

(...) a agricultura familiar deseja, precisa e não sobreviverá se não for transformada em agronegócio. Um movimento defensável por boa parcela da sociedade brasileira seria o de transformar o agronão-negócio em agronegócio-transformando um agricultor de qualquer escala, e sem acesso a mercados, em agricultor produtor de bens e serviços desejados pelas sociedades urbanizadas no Brasil e no exterior (ZYLBERSZTAJN, 2005, p. 62-63).

A visão determinista do autor, que utiliza o argumento que o "agronão-negócio" fatalmente se transformará em "agronegócio", se expressa também em sua opinião sobre o trabalho na grande exploração agrícola. O trecho a seguir é tão absurdo que merece ser destacado, por apresentar as condições dos trabalhadores rurais, reconhecidamente degradantes, como se representassem um processo positivo de mobilidade e ascensão social:

A grande produção gera renda de modo significativo e representa em muitas áreas do País uma fonte de dinamismo econômico. Atualmente, é possível ver o trabalhador rural migrar temporariamente para colher cana em São Paulo, café 
na Bahia ou frutas em Pernambuco, com a qualidade de trabalho que muitos profissionais urbanos, nas condições atuais do Brasil, invejariam (ZYLBERSZTAJN, 2005, p. 63) ${ }^{69}$.

Como também observamos no capítulo anterior, os porta-vozes do agronegócio utilizam determinadas imagens e jargões como armas ideológicas disseminadas através dos meios políticos, acadêmicos e de comunicação. No sentido de esclarecer o propósito de nossa tese sobre o papel da batalha de ideias no processo de construção do conceito de agronegócio, faremos uma breve exposição de algumas referências teóricas sobre ideologia no modo capitalista de produção.

\section{O papel da Ideologia}

Ao analisar o papel da ideologia na sociedade e no pensamento filosófico, Marx e Engels inauguram o materialismo dialético como método de pesquisa científica. Este método se constitui como base para o desenvolvimento da crítica à economia política. Em $O$ Capital Marx elabora esta crítica através do conceito de fetiche da mercadoria, que permite a compreensão da teoria do valor no modo capitalista de produção. $\mathrm{O}$ conceito de ideologia foi descrito por Marx e Engels da seguinte forma:

As idéias se sistematizavam na ideologia—compêndio das ilusões através das quais os homens pensavam na própria realidade de maneira enviesada, deformada, fantasmagórica. A primeira e máxima ilusão, própria de toda ideologia, consistia justamente em lhe atribuir a criação da história dos homens. Sob o prisma da ideologia é que a história se desenvolve como realização da Idéia Absoluta, da Consciência Crítica, dos conceitos de Liberdade e Justiça e assim por diante (MARX; ENGELS, 2007, pp. XXI-XXII).

Esta citação faz referência à oposição de Marx e Engels em relação à ideia do sujeito como criador da história. Tal concepção, própria do pensamento iluminista, imagina o sujeito como detentor dos parâmetros de "liberdade e justiça". O texto critica ainda a percepção hegeliana de "Ideia Absoluta", ou seja, a noção de que as contradições das relações sociais no modo capitalista de produção chegariam a um momento de resolução, através da vontade do sujeito. Em sua obra A Ideologia Alemã, Marx e Engels se contrapõem aos pensadores idealistas e aos empiristas, afirmando que:

Não é a consciência que determina a vida, é a vida que determina a consciência. (...) Assim que esse processo de vida ativo é apresentado, a história deixa de ser uma coleção de fatos mortos-como é para os empiristas, eles próprios ainda

\footnotetext{
${ }^{69}$ Uma série de estudos sobre as condições degradantes do trabalho no monocultivo da cana está disponível nas publicações da Rede Social de Justiça e Direitos Humanos: www.social.org.br.
} 
abstratos-, ou uma ação imaginada de sujeitos imaginados, como para os idealistas (MARX; ENGELS, 2009, p. 32).

Ao elaborar o materialismo dialético como método de análise, Marx e Engels retomam o debate filosófico sobre sujeito e objeto, contrapondo-se tanto ao pensamento positivista quanto ao iluminismo idealista. Segundo Michael Löwy, Marx e Engels "desmascaram todas as outras correntes de pensamento, desvelando, sob a máscara de objetividade, universalidade e neutralidade, a sua verdadeira face: um ponto de vista de classe tendencioso e parcial" (LÖWY, 2009, p. 96). Para o autor, tanto as correntes positivistas quanto as historicistas mantém "a ordem natural das coisas", e explica: "natural significando para os positivistas a harmonia das leis naturais eternas da vida social e, para os historicistas conservadores, o crescimento histórico 'orgânico' das instituições" (LÖWY, 2009, p. 79).

O debate sobre o papel do sujeito e o materialismo dialético como método de estudo científico e filosófico é retomado por Marx quando escreve o Prefácio da Contribuição à Crítica da Economia Política, no qual explica que:

$\mathrm{Na}$ produção social da própria existência, os homens entram em relações determinadas, necessárias, independentes de sua vontade; essas relações de produção correspondem a um grau determinado de desenvolvimento de suas forças produtivas materiais. A totalidade dessas relações de produção constitui a estrutura econômica da sociedade, a base real sobre a qual se eleva uma superestrutura jurídica e política e à qual correspondem formas sociais determinadas de consciência. $\mathrm{O}$ modo de produção da vida material condiciona o processo de vida social, política e intelectual. Não é a consciência dos homens que determina o seu ser; ao contrário, é o seu ser social que determina sua consciência (MARX, 2008, p. 45).

Em Introdução à Crítica da Economia Política, Marx explicita sua visão contrária à ideia da vontade do sujeito como parte de uma suposta "natureza humana", individual. (MARX, 2008, p. 236). Para Marx, no modo capitalista de produção só é possível conceber o sujeito como relação social.

O livro de Lukács, História e Consciência de Classe, publicado originalmente em 1922, retoma o debate sobre a relação sujeito-objeto a partir de uma perspectiva dialética, em contraposição ao pensamento positivista comum nos meios marxistas da época. Posteriormente, Theodor Adorno aprofunda tal concepção em sua crítica à "razão subjetiva", segundo a qual o conceito de ideologia é entendido no modo capitalista de produção como ilusão de separação entre sujeito e objeto, já que essa relação é mediada pela forma-mercadoria. Adorno explica que "Se a estrutura 
dominante da sociedade reside na forma da troca, então a racionalidade desta constitui os homens; o que estes são para si mesmos, o que pretendem ser, é secundário" (ADORNO, 1969, p. 4).

Esta afirmação se contrapõe à imagem iluminista do sujeito autônomo, ou da vontade do sujeito, que serviria para esconder as relações de classe no capitalismo. Quando o trabalho se torna mercadoria, não há como separar a relação sujeito-objeto. Em outras palavras, considerando-se o modo capitalista de produção como totalidade, as relações sociais passam a ser determinadas por suas categorias fundamentais. Para Adorno, "o sujeito devora o objeto ao esquecer o quanto ele mesmo é objeto. Mas, a imagem de um estado originário, temporal ou extratemporal, de feliz identificação de sujeito e objeto, é romântica" (ADORNO, 1969, p. 2).

O debate sobre ideologia é central também na obra de Guy Debord, que emprega o termo "espetáculo" para explicar como a totalidade do modo capitalista de produção se constitui no que chama de "monopólio da aparência", a partir do conceito de fetiche. O autor define "espetáculo" como "autorretrato do poder na época de sua gestão totalitária das condições de existência. A aparência fetichista (...) esconde o seu caráter de relação entre homens e entre classes". Para ele, o espetáculo se materializa como "principal produção da sociedade atual" e tem como função a "demonstração geral da racionalidade do sistema" (DEBORD, 1997, p. 17-20).

Quando descreve a Sociedade do Espetáculo, Debord se refere não apenas ao papel exercido pelos meios de comunicação de massa, mas também ao papel do Estado, das relações de classe, do trabalho abstrato e principalmente da mediação da formamercadoria no capitalismo. Através do "triunfo" do espetáculo, que significaria a universalização da forma-mercadoria no modo capitalista de produção, o autor afirma que o pensamento positivista se impõe não somente como "pretensão ideológica", mas como "evidência". Este seria o fator fundamental que gerou a ilusão sobre o "fim da historia", ou seja, sobre a impossibilidade de transformação social, como se o processo histórico fosse natural ou inevitável. O autor define ideologia como "base do pensamento de uma sociedade de classes, no curso conflitante da história" (DEBORD, 1997, p. 137).

A ideologia é analisada na obra de Mészáros (2004), que parte do entendimento que seu poder "afeta tanto os que negam sua existência quanto os que reconhecem 
abertamente os interesses e os valores intrínsecos às várias ideologias" (p. 64). Esta citação significa que o autor rejeita a ideia de que seria possível chegar a um momento de desideologia ou esclarecimento do sujeito no capitalismo. Como as relações sociais de classe são mediadas por categorias próprias deste no modo de produção, não há possibilidade de se chegar a um estágio de equilíbrio ou racionalidade exterior a tais condições materiais. O trecho a seguir aborda este ponto:

(...) a ideologia não é ilusão nem superstição religiosa de indivíduos malorientados, mas uma forma específica de consciência social, materialmente ancorada e sustentada. Como tal, não pode ser superada nas sociedades de classe. Sua persistência se deve ao fato de ela ser constituída objetivamente (e constantemente reconstituída) como consciência prática inevitável das sociedades de classe (MÉSZÁROS, 2004, p. 65).

Uma das principais funções da ideologia seria justamente criar a ilusão de consenso e normalidade em uma sociedade definida pela exploração do trabalho. Para Mészáros (2004), “o que se espera das auto-imagens da ideologia dominante (...) é fornecer apenas uma explicação plausível, a partir da qual se possa projetar a estabilidade da ordem estabelecida" (p. 69). Portanto, quando o próprio trabalho ganha forma de mercadoria como abstração concreta (nos termos que Marx descreve em $O$ Capital), o segredo que constitui a forma categorial do valor ganha aceitação social sob a figura de fetiche.

A crítica à ideia de neutralidade e objetividade como formas de camuflar posições políticas e ideológicas dos meios de comunicação foi elaborada por Edward Herman e Noam Chomsky em seu livro Manufacturing Consent (1988). Os autores analisam a difusão de determinadas ideologias através de mecanismos que chamam de "filtros" de um "modelo de propaganda". Segundo essa análise, o papel ideológico da mídia seria principalmente criar a ilusão de neutralidade e objetividade para difundir agendas políticas particulares como se representassem um suposto pensamento universal. Desta forma, a função dos meios de comunicação seria estabelecer "escolhas, ênfases e omissões" de temas e opiniões, que se tornam senso comum.

Os autores citam diversos exemplos referentes principalmente à política externa estadunidense, para mostrar que a repetição de ideias e o contexto dado a determinados fatos têm efeitos poderosos, inclusive determinando situações de guerra ou paz. ${ }^{70} \mathrm{O}$

\footnotetext{
${ }^{70}$ Este tema é analisado também por Norman Solomon em seus estudos. No livro War Made Easy, o autor afirma: "Oceanos de tinta e milhares de horas de transmissão se concentram em
} 
primeiro "filtro" identificado por Herman e Chomsky está relacionado ao controle da mídia comercial por monopólios privados, visando o lucro. A principal consequência desse modelo é a exclusão da consciência de classes, com resultados bem mais "efetivos", segundo eles, do que a censura estatal em tempos de ditadura.

Um estudo de Ben Bagdikian (1990) demonstra que cerca de 20 empresas controlam mais da metade de todos os veículos de comunicação nos Estados Unidos e em suas filiais em outros países. Isso significa controlar a produção de agências de notícias, jornais, revistas, livros, filmes, programas de rádio e televisão, além da indústria musical e digital. Bagdikian argumenta que essas empresas constituem um "Ministério Privado de Informação e Cultura". O autor identifica corporações de outra natureza (bancos, empresas bélicas, de energia, entre outras.) que detêm controle acionário de grandes veículos de comunicação. Por exemplo, a General Electric (que produz desde lâmpadas até material bélico e nuclear) controla a RCA e a rede de TV NBC; o Wall Street Journal (que estabelece a agenda do noticiário econômico mundial) é controlado pela Dow Jones.

O segundo "filtro" identificado por Herman e Chomsky é a própria estrutura da mídia comercial, cujo principal objetivo é vender os produtos dos anunciantes. Seu conteúdo, portanto, é voltado especialmente para as classes sociais consumidoras desses produtos. Antes de se estabelecer essa estrutura, os jornais, por exemplo, dependiam da venda de exemplares para cobrir seus custos de produção. Atualmente, esses custos são cobertos por propaganda de grandes empresas e de governos. Dessa forma, esses veículos podem massificar sua produção e vender jornais por um preço muito mais baixo, o que dificulta a sobrevivência de publicações não comerciais e facilita a massificação da ideologia hegemônica.

A partir dessa perspectiva, compreendemos que o produto vendido pelas empresas de comunicação a seus clientes (que são as empresas anunciantes) é o grupo de expectadores ou leitores com maior poder econômico para consumir o que é anunciado. Os interesses levados em conta são representados pela necessidade de

disputas sobre como e quando iniciar uma guerra. Não importa se estão vendendo comida do McDonald's ou carros da General Motors ou uma guerra do governo, a repetição é crucial para fazer a propaganda pegar". Original em inglês: "Oceans of ink and thousands of airtime hours concentrated on disputes over how and when to go to war. Whether you're selling food from McDonald's or cars from General Motors or a war from the government, repetition is crucial for making propaganda stick" (2005, p. 26). 
vender expectadores com poder aquisitivo para consumir os produtos anunciados nas empresas de comunicação. Para isso, é necessário construir a ilusão de neutralidade e objetividade, no sentido de gerar consenso a partir dos interesses capitalistas. Ao considerar que o produto da mídia comercial é o público expectador, os autores questionam a concepção de autonomia do sujeito no modo capitalista de produção.

Tal tese pode ser constatada quando se analisa como a mídia comercial cobre a atuação de movimentos sociais no Brasil, sejam rurais ou urbanos. Por exemplo, em relação ao Movimento Sem Terra (MST), suas ações geralmente são apresentadas com verbos de conotação violenta como invadir, saquear, destruir, obstruir. Já o latifúndio é retratado como eficiente, moderno ou gerador de riqueza e prosperidade. Mesmo quando um trabalhador rural é vítima de violência, as manchetes normalmente são: "sem-terra morto em conflito" ou "tiroteio mata sem-terra" (mesmo que só um dos lados tenha atirado), omitindo assim o agente da violência (pistoleiro, jagunço ou policial) e o substituindo por um sujeito difuso ${ }^{71}$.

De acordo com o estudo de Herman e Chomsky, a maioria das fontes de informação utilizada pela mídia comercial e considerada "confiável" é aquela expressada por órgãos oficiais ou "especialistas". Essa prática constitui o terceiro "filtro", já que normalmente exclui opiniões divergentes da ideologia dominante. A influência de setores ligados a órgãos de governo ou empresas através de lobby constitui o quarto "filtro". A pressão pode ocorrer de forma direta, através de contato com a direção dos veículos de comunicação sobre o conteúdo da programação, ou de forma indireta, através do apoio a grupos que organizam campanhas de cartas, mobilizam acionistas e outros setores influentes.

\footnotetext{
${ }^{71}$ O livro A História da Luta pela Terra e o MST (2001, pp. 218-220) traz um resumo de um estudo que realizamos em 300 matérias publicadas sobre o MST entre 20 de abril e 20 de agosto de 1999, nos jornais Folha de São Paulo, O Estado de São Paulo, O Globo e Jornal do Brasil. Dessas 300 matérias, apenas oito tinham uma conotação positiva ou neutra sobre o movimento. Nas manchetes que descreviam as ações do MST, a regra dos jornais foi utilizar verbos que expressavam violência como bloqueiam, ameaçam, incendeiam, saqueiam, invadem. No caso da descrição de assassinatos de trabalhadores sem-terra, os jornais atribuíram estes fatos a conflitos, tiroteios (mesmo que os trabalhadores estivessem desarmados) ou desocupação (omitindo o agente da violência, por exemplo, policial ou pistoleiro).
} 
Herman e Chomsky citam como exemplo o governo dos Estados Unidos, que investe pesadamente nos setores de comunicação do Pentágono, da Casa Branca e do Departamento de Estado, e que possuem milhares de funcionários e um enorme orçamento, com o objetivo de influenciar os meios de comunicação nacionais e internacionais. Outro órgão estratégico é a Câmara de Comércio dos Estados Unidos, que possui uma rede de cerca de 150 mil lobistas para difundir a ideologia do "livre mercado" (HERMAN; CHOMSKY, 1988).

Os estudos de Antonio Gramsci sobre o papel da hegemonia como forma de gerar consenso na sociedade foram fundamentais para o pensamento crítico sobre o tema. Para o autor:

O exercício 'normal' da hegemonia, no terreno tornado clássico do regime parlamentar, caracteriza-se pela combinação da força e do consenso, que se equilibra de forma variada, sem que a força suplante em muito o consenso, mas, ao contrário, tentando fazer com que a força pareça apoiada no consenso da maioria, expressado pelos chamados órgãos da opinião pública - jornais e associações —,os quais, por isso, são artificialmente multiplicados (GRAMSCI, 2007, p. 95).

Tais referências teóricas serviram de base em nossa análise sobre a construção do conceito de agronegócio, através de pesquisas em meios acadêmicos, políticos, econômicos e de comunicação. Nossa tese procurou identificar elementos e imagens comumente difundidas, que passaram a permear a opinião pública e as políticas estatais para a agricultura. É necessário esclarecer que nosso ponto de partida foi a busca da compreensão das relações sociais no modo capitalista de produção, no âmbito de suas formas categoriais como trabalho abstrato e valor, mediadas pela forma-mercadoria.

A análise de Delgado (2012) ilustra a aplicação do conceito de hegemonia para explicar o papel da agricultura na acumulação capitalista. De acordo com o autor:

A história econômica brasileira do período militar revelou um processo concreto de articulação do grande capital agroindustrial, do sistema de crédito público à agricultura e à agroindústria e da propriedade fundiária para estruturar uma estratégia econômica e política de modernização conservadora da agricultura. Esse processo, do ponto de vista da acumulação de capital, tem o caráter de um pacto da economia política, em sua acepção clássica, e é fundamentado na organização dos interesses hegemônicos de classes sociais no interior do aparelho do Estado (DELGADO, 2012, cap. 5).

O texto esclarece que a construção de hegemonia é própria das relações de classe e do papel exercido pelo Estado no capitalismo. Como parte de nossa investigação sobre 
a representação midiática da agricultura capitalista, que mais recentemente ganhou o nome de "agronegócio", verificamos que inicialmente a imprensa brasileira utilizava a palavra em inglês - agribusiness. Identificamos o uso frequente deste termo no jornal Folha de São Paulo, que foi pioneiro em sua utilização e, por ser um veículo de grande circulação nacional, consideramos relevante realizar uma pesquisa específica com base nesta palavra-chave. Nossa pesquisa abrange ainda matérias publicadas na Gazeta Mercantil, em função de elementos que começamos a investigar no capítulo anterior.

\section{O uso do termo Agribusiness no Brasil}

A palavra agribusiness foi localizada inicialmente na edição do dia 7 de dezembro de 1990 da Folha de São Paulo, quando o jornal anuncia em primeira página o impasse na principal negociação multilateral da época, o GATT (General Agreement on Trade and Tariffs), com a manchete: "Colapso da Rodada do GATT em Bruxelas Cai entusiasmo pela importação".

Aquela edição traz pela primeira vez o termo agribusiness no contexto de uma entrevista com Ray Goldberg, autor do livro A Concept of Agribusiness (1957). A reportagem intitulada "A contribuição do Agribusiness", resume as ideias de Goldberg, que representam um marco por sua influência sobre políticas agrícolas em todo o mundo, como descrevemos no terceiro capítulo deste trabalho. A seguir, incluímos um longo trecho da entrevista, por seu conteúdo emblemático que expõe o pensamento hegemônico sobre o setor chamado de agribusiness:

O mundo está numa nova encruzilhada. Se o sistema agroalimentar, que emprega metade da população economicamente ativa do planeta, responde por $50 \%$ dos ativos mundiais e produz alimentos que correspondem à metade das despesas globais de consumo, não for bem administrado, não haverá um efetivo desenvolvimento econômico, afirmou ontem o norte-americano Ray Goldberg, Diretor do Programa de Agribusiness da Harvard School of Business Administration. Goldberg está no Brasil a convite da Agroceres e participou do encontro internacional de Agribusiness. (...) Ao lado de seu colega de Harvard, John Davis, Goldberg cunhou o termo 'agribusiness' nos anos 50, para designar o conjunto de operações do complexo agroindustrial que envolve desde a produção e distribuição de insumos, a produção agrícola propriamente, até a fase após a porteira da fazenda, que inclui armazenamento, comercialização, processamento e distribuição de produtos de origem agrícola para o consumidor final. O agribusiness corresponde a uma economia de US\$5,5 trilhões em níveis mundiais. (...) Embora se constitua no maior setor da economia mundial, ele passa por uma fase de mudanças rápidas e institucionais, decorrentes da globalização dos mercados. (...) Qualquer problema em um dos elos da cadeia, diz ele, será um problema para toda a cadeia, daí a importância para que se reforcem as alianças estratégicas entre supermercados, processadoras, 
cooperativas, produtores e fabricantes de insumos. Segundo estudo da Agroceres, embora a agricultura tenha perdido expressão na composição do Produto Interno Bruto, o complexo agroindustrial é ainda hoje responsável por $32 \%$ do PIB brasileiro.

A entrevista cita a Agroceres como principal anfitriã de Goldberg no Brasil. Esta empresa, que foi fundada inicialmente para realizar a modificação genética de sementes, continua a atuar no país com foco em "tecnologias agroquímicas, genética e nutrição animal”. Em seu sítio web, é descrita como "um grupo sólido, diversificado e de atuação internacional, que se reiventa a cada dia e continua a abrir novos horizontes de eficiência, crescimento e rentabilidade para o agronegócio ${ }^{72,}$.

A matéria sobre a visita de Goldberg mostra ainda que o termo cadeia produtiva já era utilizado no Brasil e se insere na descrição do sistema que assumiria o título de agribusiness. Como mencionamos anteriormente, entendemos que tal discurso se insere em um contexto de crise-acumulação do capital e expressa a necessidade de se construir uma moldura ideológica para encobrir o movimento de apropriação da renda da terra por setores industriais, nacionais e estrangeiros. $\mathrm{O}$ trecho seguinte da reportagem que incluiu a entrevista com Goldberg faz referência ao crescente movimento de formação de monopólios no setor, através de fusões e aquisições de empresas dos diferentes ramos do agronegócio. Este processo é exaltado como forma de garantir a viabilidade deste modelo de agricultura e recebe a denominação de "aliança estratégica". Em relação à situação do Brasil, o jornal afirma:

Agribusiness: Mudanças estruturais no mercado mundial exigem maior integração - No Brasil a compra de insumos representa US\$10 bi (...). As mudanças que estão ocorrendo no setor exigem que o setor privado assuma um papel ativo na condução dos negócios (...) elas envolvem a globalização dos mercados com alianças estratégicas entre empresas, 'joint ventures'(...) em meio a uma grande disseminação de pontos de venda de 'fast-foods' e de marcas globais (Folha de São Paulo, 7/12/1990, p.15).

È interessante observar que naquele período, em que se inicia a década de 1990, era comum a imprensa brasileira defender a privatização de empresas estatais sob o argumento de que seria necessário acabar com "monopólios" para garantir "eficiência" de serviços. Por outro lado, o texto acima ilustra a conotação positiva que o jornal oferece para descrever o crescimento de monopólios privados ou joint ventures. Nesse mesmo sentido, a continuação da entrevista com Goldberg é emblemática:

\footnotetext{
${ }^{72}$ http://www.agroceres.com.br/empresa_historia.jsp. Consulta em 01/04/2013.
} 
Quem imaginaria, há sete anos, que sete ou oito cadeias dominariam o setor de super-marcados na Europa, ou que a Coca-Cola e a Nestlé se juntariam na produção de chá? disse Goldberg (...) A integração do complexo agro-industrial não se esgota nas fronteiras de cada país (...) O maior produtor de suco cítrico no Brasil é parceiro estratégico da Coca-Cola nos Estados Unidos (Folha de São Paulo, 7/12/1990, p.15).

Enquanto o processo de crescimento de monopólios privados é caracterizado de maneira positiva como "alianças estratégicas", o discurso em favor das privatizações de setores públicos da economia ganha força nos meios de comunicação. Por exemplo, no dia 29 de dezembro de 1990 a Gazeta Mercantil noticia em primeira página: "US\$2 bi para privatizar serviço público". A manchete faz referência à liberação de recursos do Banco Nacional de Desenvolvimento Social e Econômico (BNDES) para financiar a privatização de empresas estatais de energia e transporte. Apesar de ter anunciado que as privatizações ocorreriam com verbas públicas, a mesma edição do jornal traz um artigo que dissimula esta informação e deixa a impressão de que o setor privado estaria financiando estes negócios:

A disposição das grandes empreiteiras, consumidores intensivos de energia e fornecedores de equipamentos para obras públicas de investirem em serviços públicos, advém da consciência de que o Estado não tem mais condições de bancar essas inversões, essenciais para o bom andamento dos negócios do capital privado (Gazeta Mercantil, 29/12/1990, p. 3).

A partir de 1995 a Gazeta Mercantil passa a manter uma página específica com o título de Agribusiness, que prioriza temas relacionados ao comércio exterior. Naquele momento verifica-se que o processo de privatização já teria sido institucionalizado mais amplamente no Brasil, especialmente com a criação do Conselho Nacional de Desestatização, como mostra a seguinte manchete: "Decreto permitirá participação de estrangeiros no setor de serviços - A reunião do Conselho de Desestatização (...) pode inaugurar uma nova fase do programa de privatização". Esta nova fase descrita pelo jornal incluiria a privatização de bancos, dos setores de energia elétrica, água e saneamento, além da autonomia do Banco Central (Gazeta Mercantil, 27/02/1995, p. 3).

Outra empresa que sofreu modificações naquele período, sob o argumento da necessidade de "quebra de monopólio", foi a Petrobrás. No dia 21 de dezembro de 1995 a Gazeta Mercantil noticia mudanças na estrutura da empresa e publica uma manchete de primeira página intitulada, "As idéias do governo para a Petrobrás”. A matéria afirma que "O Ministro de Minas e Energia, Raimundo Brito, apresentou, ontem, ao Conselho Nacional de Desestatização (CND) o anteprojeto de lei que regulamenta a quebra do 
monopólio da Petrobrás na exportação de petróleo.” Na mesma edição, o editorial reforça a opinião de que as privatizações poderiam solucionar a crise da dívida trazendo "receitas" para o país, além de enfatizar a defesa do Estado mínimo: "A privatização é de importância fundamental, tanto pelas receitas que proporciona quanto pelo seu efeito reformista, ao reduzir o papel do Estado" (Gazeta Mercantil, 21/12/1995 p. A 2).

Este mesmo tipo de discurso predomina no jornal, também travestido do slogan que promovia uma "nova ordem econômica". A manchete de primeira página publicada em 28 de março de 1995 é categórica ao anunciar:

Prioridade é a nova ordem econômica - O governo decidiu correr com a tramitação das emendas constitucionais da ordem econômica, ou seja da flexibilização dos monopólios estatais, e discretamente frear a reforma da previdência social até que as mudanças sejam mais bem digeridas pela opinião pública. O presidente FHC deverá voltar ao rádio e a televisão, em cadeia nacional, para insistir que essa reforma é imprescindível (Gazeta Mercantil, 28/03/1995, p. 1).

Nesse mesmo dia, o editorial reforça os ataques ao que chama de "monopólios estatais" que, segundo o texto, eram defendidos por setores políticos de esquerda considerados "atrasados". O artigo foi publicado poucos meses depois da eleição do presidente Fernando Henrique Cardoso, que exercia o papel de reforçar o ideário neoliberal de Estado "mínimo" ao mesmo tempo em que prosseguia com o financiamento público para as privatizações. $\mathrm{O}$ texto editorial afirma:

Sabotagem desmascarada - O Presidente FHC recebeu das urnas um lídimo e inconfundível mandato para realizar as reformas estruturais indispensáveis para que o País possa desenvolver-se e tornar-se uma sociedade mais justa. (...) a indignação do presidente FHC ao desmascarar, em termos veementes, a 'falsa esquerda' que hoje se coloca na 'vanguarda do atraso', aferrando-se à defesa de grandes corporações estatais e dos monopólios (Gazeta Mercantil, 28/03/1996, p. 4).

No dia 6 de março de 1995 o jornal publica notícias sobre a reforma agrária, que não eram publicadas com frequência naquela época, já que a prioridade das matérias sobre agricultura era a cobertura de temas relacionados ao monitoramento do mercado de commodities. O trecho da reportagem abaixo revela que a questão fundiária volta à pauta do governo:

Reforma agrária - Nova proposta de desapropriação - O Ministro da Agricultura, José Eduardo de Andrade Vieira, deve encaminhar hoje ao presidente $\mathrm{FHC}$, proposta de desapropriação de 575 mil hectares de terras consideradas improdutivas, que deverão integrar o Programa de Reforma Agrária. No inicio de janeiro, o ministro já havia encaminhado proposta de desapropriação de outros 415 mil hectares. Com isso, já são cerca de 1 milhão 
de hectares que o governo se dispõe a desapropriar nestes primeiros meses do ano (Gazeta Mercantil, 6/3/1995, p. 3).

A cobertura do debate sobre a questão agrária é estimulada por uma conjuntura que permitiu o crescimento de mobilizações sociais no campo em defesa da reforma agrária e da agricultura camponesa. Por exemplo, em 23 de março de 1995, a Gazeta Mercantil publica a seguinte matéria:

Novos protestos no Sul - cerca de 10 mil trabalhadores rurais (...) participaram ontem de uma mobilização em Passo Fundo. Segundo dados da FETAG existem hoje no estado perto de 430 mil pequenas propriedades responsáveis pela produção de $84 \%$ do feijão, $84 \%$ da mandioca, $40 \%$ da soja, $70 \%$ do milho e $75 \%$ do leite (...) informa o documento elaborado pela entidade (...). A crise da pequena propriedade levará ao aumento do êxodo rural, tendo por conseqüência o aumento da fome (Gazeta Mercantil, 23/03/1995, p. 3).

Apesar da pressão dos movimentos sociais rurais para que o governo priorizasse políticas de apoio à produção de alimentos para abastecer os mercados locais, como forma de lidar com o problema da fome, o que ocorria naquele período era um crescente processo de privatização dos estoques de alimentos. A manchete de 23 de março enaltece tal política: "Agribusiness - Solução para o desvio dos estoques é a privatização, afirma Vieira" (Gazeta Mercantil, 23/03/1995, p. 21).

A defesa das privatizações de setores públicos da economia se contrasta com a cobertura do processo fusões e aquisições de empresas do agronegócio, apresentado como benéfico e essencial. O tema ganha espaço no jornal, principalmente nas páginas com título de agribusiness. A matéria abaixo, por exemplo, faz apologia ao controle que a multinacional Cargill passa a exercer sobre a produção de soja no Brasil: "Cargill arrenda unidade industrial na Bahia - A Cargill agrícola fechou contrato de arrendamento da fábrica de processamento de soja da Olvebasa (...) cuja capacidade é de 265 toneladas por ano" (Gazeta Mercantil, 28/03/1995, p. 17).

Com conteúdo semelhante, o artigo publicado em 7 de dezembro de 1995 comemora a entrada crescente de capital internacional em países latino-americanos e, mais uma vez, descreve as fusões entre capitais privados e empresas estatais como "alianças estratégicas". O jornal promove a opinião de "analistas internacionais" sobre o tema, como demonstra a entrevista com Peter Pekan Jr., consultor da empresa americana Booz-Allen \& Hamilton:

É tempo de alianças estratégicas - Tradicionalmente, a América Latina tinha fortes controles governamentais, regras econômicas incertas e instáveis e discriminação contra 
investimento estrangeiro (...). Hoje estão ocorrendo dramáticas mudanças para economias de mercado (Gazeta Mercantil, 7/12/ 1995, p. C1).

Seguindo esta mesma linha, em 5 de dezembro de 1995 o jornal publica a seguinte manchete: "Kraft e Bunge, a união que emplacou no Brasil - A Kraft, maior fabricante de alimentos nos Estados Unidos e a segunda no mundo, controlada pelo grupo Philip Morris, cujas vendas atingiram US\$60 bilhões por ano, poderá instalar uma fábrica no Brasil já em 1997”. Mais uma vez, a Gazeta Mercantil repete sua linha editorial que exalta os monopólios privados e difunde a ideologia neoliberal de apoio a um suposto Estado mínimo.

Entretanto, é possível encontrar neste mesmo periódico algumas notícias que demonstram que o Estado brasileiro nunca deixou de ser máximo para grandes empresas e para o latifúndio, que receberam continuamente subsídios e outras formas de financiamento estatal. Verificamos, por exemplo, dados sobre constantes rolagens de dívidas de empresas do agronegócio com bancos estatais. Em 1 de dezembro de 1995, a Gazeta Mercantil noticia: “Agribusiness - Dívidas rurais são prorrogadas - O Tesouro Nacional irá emitir os títulos que permitirão a securitização de $\mathrm{R} \$ 7$ bilhões das dívidas (...) O prazo de pagamento é de sete anos com um ano de carência” (p. B16).

O histórico de rolagem de dívidas da agricultura extensiva reforça nossa tese de que o principal negócio do chamado agronegócio é o acesso a créditos públicos e, portanto, seu produto não seria soja, cana, laranja, eucalipto ou qualquer outro cultivo, e sim a própria dívida. Como observamos em estudos anteriores, há uma relação simbiótica entre o agronegócio, o Estado, o mercado financeiro e o mercado de terras. $\mathrm{O}$ próprio movimento de concentração de capitais e formação de monopólios tem como determinação principal inflar os ativos das empresas e com isso aumentar seu poder de barganha para acessar crédito e subsídios estatais, mesmo que tenham um histórico de acumular dívidas impagáveis. È neste sentido que entendemos a predominância do capital fictício nos negócios do agronegócio. A elaboração de Delgado (2012) sobre o tema esclarece que:

Como historicamente a estratégia de capital financeiro na agricultura depende desses mercados organizados - de terras, de crédito e dos complexos agroindustriais; e como esses mercados dependem essencialmente da regulação (ou desregulação conforme o caso) e provisão estatal, o capital financeiro na agricultura irá se configurar como virtual pacto de economia política entre cadeias agroindustriais, grande propriedade fundiária e o Estado, tendo em vista viabilizar uma pareceria estratégica (DELGADO, 2012, cap. 5). 
O setor canavieiro se destaca como exemplo deste tipo de articulação, pois historicamente e até a atualidade acumula constantes rolagens de dívidas ${ }^{73}$. A matéria abaixo revela a situação de crise nas usinas de cana-de-açúcar na década de 1990:

Acuada por dívidas, Usina Santa Bárbara é desativada - O grupo Costa Pinto vai desativar a Usina Santa Bárbara, uma das mais antigas e importantes de Piracicaba. Com 74 anos de atividade industrial, a usina vinha enfrentando uma sucessão de problemas políticos, ambientais e de falta de investimentos. (...) $\mathrm{Na}$ área ambiental, a Santa Bárbara acumulou US\$17 milhões em multas da CETESB pela queima da palha da cana-de-açúcar (...). Nenhuma das multas chegou a ser paga (Gazeta Mercantil, 7/12/1995, p. B16).

Apesar de toda a propaganda que imperou durante aquele período, exaltando o modelo das privatizações como solução para a crise da dívida, no início de 1999 quando o receituário neoliberal já estava bastante avançado, verificamos que a imprensa continuava a noticiar um panorama de crise. O seguinte editorial da Gazeta Mercantil expõe tal situação, porém defende a necessidade de manter a política econômica:

Avanços que devem ser perseguidos - $\mathrm{O}$ desempenho da economia brasileira no ano que acaba de se encerrar não confirmou as expectativas otimistas projetadas pela equipe econômica (...). A balança comercial fecha o período amargando um saldo negativo de aproximadamente US\$6,3 bi - o quarto déficit consecutivo (...). Os índices de desemprego podem não ser alarmantes, mas são preocupantes o bastante a ponto de levar combativos sindicatos a homologar contratos de trabalho 'flexíveis', abrindo mão de pontos considerados intocados há questão de poucos anos (...). Ainda que este cenário inspire apreensão, importantes e consistentes progressos foram registrados. Merece destaque, nesse sentido, o avanço do programa de privatizações (...) o governo federal encerrou $\mathrm{o}$ ano privatizando 17 estatais e reforçando o caixa do Tesouro (Gazeta Mercantil, 04/01/1999, p. A2).

O editorial menciona ainda a crescente vulnerabilidade dos sindicatos com a introdução de medidas de flexibilização dos direitos trabalhistas. O texto revela a relação entre o aprofundamento do programa de privatizações e o aumento do nível de exploração do trabalho. Aquele período foi marcado também pela flexibilização da legislação ambiental, como mostra a manchete de primeira página publicada em 12 de janeiro:

\footnotetext{
${ }^{73}$ Ver MENDONÇA; PITTA; XAVIER, A Agroindústria Canavieira e a Crise Econômica Mundial (2012). Disponível no sítio:

http://www.social.org.br/relatorioagrocombustiveis2012.pdf.
} 
Agricultor livre de recuperar florestas - O presidente FHC acaba de baixar uma Medida Provisória que reduz a área a ser preservada em propriedades rurais, dispensa o agricultor de recuperar florestas degradadas e permite que ele cultive toda a sua área, criando uma reserva legal fora de sua gleba principal. A MP 1736-31 também reduz de $80 \%$ para $20 \%$ a área a ser preservada em propriedades nas manchas do Cerrado da região amazônica (Gazeta Mercantil, 12/01/1999, p.1).

Verifica-se, portanto, um movimento simultâneo de expansão territorial do agronegócio, com consequente aumento da exploração de recursos naturais, ao mesmo tempo em que ocorre maior intensificação da concentração de capitais. Este é o tipo de combinação de elementos que nos leva a analisar o processo de construção do agronegócio em um contexto simultâneo de crise-acumulação de capital. $\mathrm{O}$ anúncio de novas fusões entre empresas, chamadas de "parcerias estratégicas", ilustra tal cenário, como vemos na notícia publicada na página com título de Agribusiness:

Monsanto faz parceria com Scotts na área de jardinagem - A Monsanto Co., empresa da área de biotecnologia agrícola, e a Scotts Co., maior empresa de produtos para jardinagem, formaram uma joint venture (...). As empresas vão produzir gramas transgênicas resistentes ao herbicida Roundup da Monsanto (...). Esta é a mais recente aliança feita pela Scott, que fatura US\$1,1 bi (...). Até agora a Scott concentra operações na fabricação de produtos para o tratamento de plantas (Gazeta Mercantil, 04/01/1999, p. B24).

A reportagem publicada no dia 12 de janeiro segue a mesma linha, com ênfase na fusão de capitais de empresas de arroz com um grupo de negócios financeiros nos Estados Unidos. Segundo a matéria, esta negociação seria positiva por trazer "capital global" para um setor "pulverizado" e "atrasado":

Agribusiness: A globalização chega ao arroz - A compra de $50 \%$ da Camil Alimentos S.A. pelo fundo norte-americano de investimentos Trust Company of the West (TCW), e a incursão da Agrevo no mercado de sementes de arroz, inauguram a chegada do capital global a um dos segmentos da cadeia agroalimentar mais pulverizados e atrasados do ponto de vista mercadológico (Gazeta Mercantil, 12/01/1999, p. B20).

A ideia de atraso é usada em contraposição à interpretação dada à imagem de modernidade do agronegócio, relacionada com a formação de monopólios privados e maior participação de empresas estrangeiras neste setor ${ }^{74}$. A conotação positiva

\footnotetext{
${ }^{74}$ Mészáros (2004) esclarece que a ideia de "modernidade" definida como contrária ao que seria "tradicional" ou "atrasado" significa que este tipo de interpretação permite "escolher bem arbitrariamente os termos de seus pressupostos definidores" (p. 73). Ou seja, este tipo de classificação é arbitrário porque "modernidade" é uma categoria que implicará sempre em se considerar o contexto das relações sociais no capitalismo.
} 
empregada pelo jornal para descrever tal política pode ser contestada através de dados sobre o preço dos alimentos. Como veremos na matéria a seguir, a desregulamentação da política agrícola causou aumento no preço dos alimentos para consumo interno, principalmente em produtos produzidos pelas empresas chamadas de "gigantes" do agronegócio e "líderes no mercado":

Cesta básica pressionada - (...) os aumentos se concentraram principalmente nos itens de alimentação e higiene pessoal com marcas líderes no mercado. $\mathrm{O}$ café em pó das marcas Pilão e Caboclo da empresa União, com $20 \%$ do mercado, ficou 3,90\% mais caro. O óleo de soja da Ceval (grupo Bunge) aumentou 2,78\%, com tendência de alta. As margarinas também líderes no mercado, Claybon e Doriana, da gigante Gessy Lever, apresentaram altas de $1,22 \%$ e 1,15\% (Gazeta Mercantil, 25/01/1999, p. 1).

Naquele mesmo dia, o editorial da Gazeta Mercantil procura justificar a continuidade das políticas neoliberais, mesmo frente à clara situação de crise econômica. Com o título À procura de um ponto de equilíbrio, o texto atribui problemas econômicos ao que chama de "fardo do Estado" e à necessidade de "ajuste" na "máquina administrativa":

Ao desengessar a economia, derrubando a política de câmbio controlado, monoliticamente conduzida nos últimos 50 anos, o governo (...) deu oportunidade para que as forças de mercado pudessem operar com liberdade. (...) Um passo na direção correta que o País deve tomar: o da implementação das reformas que ajustem a máquina administrativa e removam o fardo do Estado sobre empresas e contribuintes (Gazeta Mercantil, 25/01/1999, p. 2).

Este tipo de abordagem é típico das análises políticas acríticas em relação às contradições inerentes ao modo capitalista de produção. Consequentemente, o debate comumente travado sobre a política econômica se limita a discutir medidas administrativas, ignorando o próprio papel do Estado moderno no capitalismo. Desta forma, o escopo da discussão passa a ser puramente mecânico, entre uma posição que defende o desmonte do Estado de bem-estar social e aquela que apoia a manutenção de certas políticas reguladoras exercidas pelo Estado no capitalismo. Porém, excluídas as ilusões sobre as supostas diferenças entre o que representaria um bom e um mau capitalismo, tanto as políticas baseadas no pensamento neoliberal quanto no keynesiano manterão o Papel do Estado de transferir mais-valia social para o setor privado. Outro pressuposto da teoria keynesiana é imaginar que o progresso técnico seria a solução para problemas econômicos. Como explica Mészáros (2004), Keynes “oferece o prêmio moral-religioso da 'recompensa final' aos indivíduos - para quem a terra prometida 
está no além, (...) aceitando assim com santa resignação a ordem estabelecida das coisas" (p. 63).

No início dos anos 2000, as páginas da Gazeta Mercantil sobre agricultura priorizam notícias sobre condições climáticas das safras agrícolas e sobre o mercado de commodities. Outro assunto frequente continua sendo a cobertura de fusões entre grandes empresas do agronegócio, sempre com conotação positiva ao mesmo tempo em que o jornal combate os "monopólios" estatais. A matéria de primeira página, publicada em 23 de julho de 2002, ilustra essa tendência:

A Bunge fica com a Cereol e é líder na soja - A Bunge Ltda. assumiu a liderança mundial no processamento de soja com a compra da francesa Cereol por $\$ 1,58$ bi de Euros. Com o negócio, a Bunge passará a esmagar 34 milhões de toneladas de grãos por ano e supera as rivais Archer Daniels Midland (ADM) e Cargill, que esmagam cerca de 30 milhões de toneladas cada uma (Gazeta Mercantil, 23/07/ 2002, p1).

É interessante observar que as empresas que se constituem como monopólios privados recebem sempre adjetivos positivos como "líderes" ou "gigantes". As aquisições de empresas menores por grandes grupos econômicos do agronegócio ocorrem também, e de forma bastante intensa, no segmento de comercialização internacional de grãos, como revela a seguinte matéria:

Trigo: Cargill e Graincorp levam a Goldman Fielder - A Cargill e a Graincorp anunciaram a aquisição dos ativos do setor de farinha de trigo da australiana Goldman Fielder por US\$109 milhões. O negócio torna as duas empresas controladoras da maior compradora de trigo para pão no País (Gazeta Mercantil, 19/08/2002, p. B16).

O tema da rolagem da dívida do agronegócio continua a aparecer nos noticiários, como ilustra a reportagem publicada na página sob o título de Agribusiness, que indica um endividamento de pelo menos dez bilhões de reais no final da década de 1990:

Produtores atrasam pagamento da dívida securitizada - O Banco do Brasil recebeu apenas $30 \%$ da segunda parcela das dívidas agrícolas securitizadas em 1995, que venceram no dia 31 de outubro de 1998, no valor de $\mathrm{R} \$ 1,2$ bi. Cerca de $70 \%$ deste total teve que ser prorrogado. Os produtores rurais já não haviam quitado, em outubro de 1997, a primeira prestação dos débitos, no total de $\mathrm{R} \$ 800$ milhões (...). Em outubro deste ano vencerá a terceira parcela, também no valor de $\mathrm{R} \$ 1,2$ bi. $\mathrm{O} \mathrm{BB}$ tem a receber dos produtores rurais, em dívidas antigas, um total de R\$10 bi (Gazeta Mercantil, 12/01/1999, p. B19).

Temas e tendências como endividamento e crise na agricultura, assim como a crescente concentração de terra e capital, permanecem na pauta política até a atualidade. No capítulo a seguir vamos investigar como a palavra agronegócio passa a ser usada 
frequentemente na imprensa brasileira e a fazer parte do senso comum em relação à política agrícola. 


\section{Capítulo 6 - A difusão do termo agronegócio na Brasil}

\section{De agribusiness a agronegócio: análise da representação na imprensa}

através do jornal Folha de São Paulo

Com o objetivo de ilustrar o processo social que popularizou o termo agronegócio no Brasil, utilizamos como exemplo o jornal Folha de São Paulo, por ser pioneiro na utilização do termo e se constituir como um dos veículos de maior circulação diária na imprensa brasileira durante o período pesquisado. A palavra agronegócio começa a ser utilizada no jornal em 1994. De 1994 a 1997 a palavra só aparece seis vezes no jornal e, em 1998, 14 vezes. A partir de 2000, o termo passa a ser utilizado com mais frequência e naquele ano aparece em 27 artigos. Nos anos seguintes a frequência é: em 2001, 60 vezes; em 2002, 132 vezes; em 2003, 238 vezes; em 2004, 378 vezes; em 2005, 452 vezes e a partir de 2006 se mantém nessa média. Naquele período o jornal também usa o termo agrobusiness (com a grafia errada em inglês), inclusive em subtítulos das páginas sobre o tema.

A primeira vez em que aparece o termo agronegócio na Folha de São Paulo é em um artigo de José Eli da Veiga, em 16 de janeiro de 1994. O título "Negociando a extinção da fome" sugere a posição do autor, que propõe um "pacto social" entre a sociedade brasileira e o chamado "agronegócio". De acordo com Veiga, não se deve apontar "vilões", mas sim dividir a "responsabilidade" pela fome no país entre "cada um de nós". Porém, o problema, segundo ele, seria "O atual discurso do representante do agribusiness", que descreve como "um forte indício de que ainda não amadureceram as condições subjetivas necessárias ao estabelecimento desse tipo de contrato social".

Veiga identifica que o discurso do setor é "de cunho puramente ideológico" e defende uma política de produção abundante e acessível de alimentos baratos como forma de distribuição de renda. Um dos argumentos contestados seria a reclamação dos produtores, que dizem ter investido fortemente em tecnologia, porém obtêm menores lucros com a oferta maior e a queda dos preços dos alimentos. Veiga rebate este argumento e cita dados da publicação Informações Fipe, de janeiro de 1993, que 
indicam que "nos últimos quatro anos o custo da alimentação tendeu a se fixar em um nível $11 \%$ superior ao de 1980,75 .

$\mathrm{O}$ texto identifica que medidas em apoio à produção de alimentos para $\mathrm{o}$ mercado interno seriam essenciais em um projeto de distribuição de renda no Brasil. Porém, o autor justifica a ausência deste tipo de política como se dependesse de "condições subjetivas" para se alcançar um "pacto social". Seu argumento se dilui ainda mais quando coloca a responsabilidade em "cada um de nós". Com isso, Veiga imagina que esta questão se resolveria se a sociedade assumisse sua "culpa" e, dessa forma, os "vilões" do agronegócio poderiam ser convencidos a realizar o tal "pacto social". Para além da narrativa que lembra filmes de mocinho e bandido, o autor omite a opção ideológica do Estado brasileiro por um determinado modelo agrícola, baseado na grande exploração. Além disso, ignora as contradições próprias da agricultura capitalista.

Como vimos no terceiro capítulo, os próprios representantes do agronegócio reconhecem que a predominância do modelo de monocultivo extensivo na agricultura, combinado à intensificação do uso de insumos químicos e industriais, gerou uma tendência de diminuição da taxa de lucro. É necessário, portanto, retomarmos a teoria de Marx sobre a renda da terra como fonte de sobrelucro que tende a ser apropriada por capitais mais produtivos. A criação do chamado agronegócio se caracteriza por aprofundar a tendência de desequilíbrio na composição orgânica do capital, que significa o aumento relativo da parte constante em relação ao capital variável. Com isso, há uma diminuição na própria possibilidade de valorização do valor, em outras palavras, na capacidade deste capital explorar mais-valia. As contradições identificadas neste modelo agrícola devem ser analisadas a partir de seu caráter ao mesmo tempo objetivo e subjetivo, como as relações sociais no modo capitalista de produção.

A segunda vez em que a palavra agronegócio aparece na Folha de São Paulo é também em um artigo de José Eli da Veiga, em 20 de abril de 1994, intitulado "O caminho (esquecido) do combate à pobreza". ${ }^{76} \mathrm{O}$ autor reitera o papel dos preços e acesso a alimentos como essencial para a distribuição de renda, porém coloca a ênfase de sua explicação em "alterações do balanço global entre disponibilidade e consumo de

\footnotetext{
${ }^{75}$ http://www1.folha.uol.com.br/fsp/1994/1/16/dinheiro/5.html. Consulta em 04/02/2011.

${ }^{76}$ http://www1.folha.uol.com.br/fsp/1994/4/20/dinheiro/4.html. Consulta em 04/02/2011.
} 
alimentos". De acordo com esta afirmação, a questão se resumiria a um problema de oferta e procura. O trecho a seguir reforça tal argumento: "O quadro 'Disponibilidade 'per capita' de calorias' mostra que a disponibilidade calórica não mais voltou ao nível de 1980, em clara sintonia com a estagnação do consumo. E é esse empate que impede o barateamento da comida". O texto defende que a solução seria aumentar a produtividade da agricultura e, ao mesmo tempo, ter políticas distributivas. Porém, a própria lógica capitalista segundo a qual o aumento da produção causaria a diminuição de preços se torna inviável quando a agricultura extensiva seria incapaz de gerar lucro. Como analisamos nos capítulos anteriores, o produto da agricultura capitalista é a busca por valorização e não a produção de alimentos.

A tese de Veiga imagina que "É necessário, portanto, conseguir que a oferta de alimentos supere sistematicamente a demanda. Isto só se tornará possível se agricultores e indústrias alimentares estiverem engajados na corrida tecnológica". Novamente identificamos a ideia de que o avanço tecnológico resolveria problemas como fome, pobreza e que, ao mesmo tempo, os agricultores capitalistas ficariam felizes através de um "contrato social" com os pobres. Ora, a chamada "corrida tecnológica" defendida por Veiga é justamente um dos fatores da inviabilidade deste modelo agrícola.

A ideia da necessidade de promover avanço tecnológico na agricultura é recorrente entre defensores do agronegócio, como mostra o artigo de Antonio Kandir intitulado "São Paulo deve apostar firme na modernidade", publicado em 9 de janeiro de 1994. O autor se refere ao período do governo de Juscelino Kubitschek como "alavanca" do desenvolvimento e de um "ciclo de expansão econômica". Ao mesmo tempo, adverte que houve uma "desconcentração industrial" no país através de "processos de inovação tecnológica que impulsionaram o agrobusiness em outras regiões do país- e a crise do modelo de desenvolvimento baseado na substituição de importações ${ }^{77,}$.

A palavra agrobusiness (com grafia errada) aparece 15 vezes na Folha de São Paulo em 1994. O centro do argumento dos artigos sobre o tema permanece focado no desenvolvimento tecnológico como suposta saída para a crise na agricultura, que se expressa pelo processo mais acelerado de liberalização comercial (descrito na citação acima como "substituição de importações").

\footnotetext{
${ }^{77}$ http://www1.folha.uol.com.br/fsp/1994/1/09/dinheiro/7.html. Consulta em 04/02/2011.
} 
Verificamos que o discurso baseado na defesa do avanço tecnológico torna-se bastante conveniente no sentido de conciliar as ideologias desenvolvimentista e neoliberal. Ou seja, permanece a defesa da necessidade de investimento estatal no agronegócio e, ao mesmo tempo, da liberalização comercial. Por exemplo, Kandir exalta as "vantagens para a produção intensa em tecnologia e conhecimento" no estado de São Paulo, que seriam consequência da "presença da ponta mais avançada da indústria nacional e transnacional". O artigo conclui que, para ganhar a "aposta na modernidade" seria necessário "uma reforma profunda da máquina do governo e novas formas de parceria entre o setor público e a iniciativa privada, sobretudo para dar um grande salto à frente nos campos da educação e do desenvolvimento tecnológico", 78

A tendência de crise e desindustrialização na agricultura paulista coincide com um processo de avanço de monocultivos de cana e laranja, para atender a demanda do mercado externo, ao mesmo tempo em que o jornal noticia e diminuição de outros cultivos no estado. Duas matérias publicadas em 18 de janeiro de 1994 demonstram este processo. A primeira, intitulada "Agrobusiness dita novo perfil agrícola", traz uma entrevista com Marcos Jank, então assessor para Assuntos Internacionais da Secretaria de Agricultura de São Paulo, que descreve tal cenário: “O novo perfil da agricultura paulista mostra que a estrutura agrária do Estado está baseada em duas grandes monoculturas: um produto energético e outro de comércio exterior". O próprio Jank alerta que, "Os dois produtos correm riscos. A cana por ser sustentada por programa de governo e a laranja, sem base de mercado doméstico, está sempre sujeita às instabilidades do mercado internacional". A matéria demonstra que, "Boi, café e algodão migraram para o Centro-Oeste, em busca de infraestrutura e terras mais baratas. Ficaram no interior paulista culturas selecionadas pelo agrobusiness e capazes de oferecer maior rentabilidade por hectare". ${ }^{79}$ Mais uma vez, percebe-se a incoerência do discurso que exalta a suposta possibilidade de obtenção de lucro com o modelo chamado de "agrobusiness", porém reconhece que este setor é dependente de subsídios do Estado e das especulações do mercado internacional.

A autora da matéria, jornalista Bety Costa, entrevista também Nelson Martin, pesquisador do Instituto de Economia Agrícola (IEA), que afirma:

\footnotetext{
${ }^{78}$ http://www1.folha.uol.com.br/fsp/1994/1/09/dinheiro/7.html. Consulta em 05/02/2011.

${ }^{79} \mathrm{http}: / / \mathrm{www} 1$. folha.uol.com.br/fsp/1994/1/18/agrofolha/2.html. Consulta em 05/02/2011.
} 
(...) o debate que se travava em relação à agricultura na década de 60 , que envolvia duas correntes. A primeira preconizava a reforma agrária para criar uma ampla classe de produtores rurais de médio porte. A segunda corrente defendia a modernização da agricultura através do desenvolvimento do capitalismo no campo. No caso de São Paulo, foi realizado um esforço crucial para viabilizar a presença do capital no interior, desde a geração de tecnologias, que propiciaram ganhos significativos, até políticas consolidando o complexo rural. Cada região do Estado respondeu de forma específica. (...) Num extremo está situada a chamada agricultura de mercado, praticada nas regiões de Campinas e Ribeirão Preto. Com um complexo rural diversificado nas agroindústrias, ela envolve grupos industriais e cooperativas. No outro extremo está a agricultura de baixa renda, concentrada nos bolsões onde o agrobusiness não chegou, como no Pontal do Paranapanema e Vale do Ribeira (Folha de São Paulo, 18/01/1994) ${ }^{80}$.

Esta entrevista reflete o tipo de discurso que propaga a imagem do "agrobusiness" relacionada com o "desenvolvimento do capitalismo", em oposição a um projeto de reforma agrária, que seria associado à "agricultura de baixa renda". Mais uma vez, observamos que tal posicionamento busca defender o modelo agrícola extensivo e a liberalização comercial como meios de gerar desenvolvimento rural.

Sob o título "Cana e laranja roubam espaço do boi em SP", outra matéria publicada naquela edição traz dados do Instituto de Economia Agrícola (IEA) que constatam o aumento dos monocultivos no estado de São Paulo:

Cana e laranja tomaram espaço do boi, café e algodão nos últimos 20 anos em São Paulo. Juntas as duas culturas ganharam 2,1 milhões de hectares entre 1972 e 1993, praticamente a mesma área que o café, o algodão e as pastagens perderam no período. (...) A cana incorporou 1.065.057 hectares em 20 anos, saltando de 729.933 ha (72) para 2.333.990 ha em 93. Um ganho de área de $220,19 \%$. Neste período a laranja cresceu $236,28 \%$, de 222.000 ha para 746.538 ha. Nos últimos quatro anos, porém, perdeu 43.200 ha, cedendo espaço também para a cana. As duas culturas, que em 70 representavam 14\% do valor bruto da produção agropecuária do Estado, hoje respondem por $42 \%$. O maior aumento percentual de área foi para a soja, com 434,63\%, passando de 93.551 ha, em 72, para 500.150 ha em 93. As pastagens, que haviam perdido 1.841 .443 ha $(15,7 \%)$ entre 72 e 89 , conseguiram recuperar $6,10 \%$ (613.508 ha) entre 89 e 93. (...) O café, que já foi a grande vedete da agricultura paulista, perdeu terreno, enquanto lavouras como mamona e amendoim estão desaparecendo do mapa agrícola do Estado. A forte queda dos preços internacionais reduziu em quase $60 \%$ a área do café (de 789.966 ha para $323.200 \mathrm{ha}$ ) entre 72 e 93 . A mamona, que ocupava 58.288 ha em 72 , está limitada hoje a 1.940 ha. O amendoim perdeu, no mesmo período, 288.573 ha, caindo de 485.693 ha para 197.120 ha. Com preços baixos e sofrendo a concorrência das importações, o algodão também perdeu espaço. De 645.587 ha em 72, sua área foi reduzida para 142.820 ha em 93, com queda de $77,8 \%$. O

\footnotetext{
${ }^{80}$ http://www1.folha.uol.com.br/fsp/1994/1/18/agrofolha/2.html. Consulta em 05/02/2011.
} 
trigo, que chegou a crescer $71,54 \%$ entre 1972 e 1989 , atingindo 198.159 ha, "encolheu" 155.704 ha nos últimos quatro anos. ${ }^{81}$

Os dados acima demonstram a tendência de diminuição da diversificação agrícola como consequência da expansão do modelo do agronegócio. Outras reportagens publicadas naquele período tratam do impacto desta política na produção de alimentos. O editorial do caderno Agrofolha, de 1 de maio de 1994, alerta que "Se o país crescer, pode faltar comida". O título faz referência à expectativa de que a política de controle da inflação possa promover uma retomada do crescimento econômico no país. A defesa de políticas de "ajuste fiscal" era predominante e se apresentava em contraposição ao que teria representado o momento anterior de maior intervenção estatal na economia. "O retorno da política de crédito subsidiado, praticada durante as décadas de 60 e 70, está fora de questão", diz o texto. O mesmo artigo prevê a necessidade do aumento de crédito para a agricultura extensiva, além do crescimento da área cultivada: “Terra não falta. A região dos cerrados, no Brasil Central, possui cerca de 85 milhões de hectares próprios para a agricultura, o suficiente para se produzir mais de 400 milhões de toneladas de grãos ${ }^{82, "}$

A difusão da ideia de que a agricultura nos moldes do agronegócio seria a solução para resolver a escassez de comida no mundo tem sido difundida principalmente a partir dos anos 1950, através do modelo que ficou conhecido como "revolução verde". Nos anos 1990, defensores da ideologia neoliberal se utilizam deste tipo de mensagem para reivindicar recursos públicos para o agronegócio.

Na mesma edição de 1 de maio de 1994, a Folha de São Paulo traz uma matéria que afirma: "Ministério da Fazenda dita política agrícola". A constatação faz sentido já que o tema central em pauta naquele período era a necessidade de "controlar a inflação". Fica claro que o modelo agrícola baseado no monocultivo para exportação é parte integral da política econômica neoliberal, sob o argumento da necessidade de se desenvolver esse setor como forma de equilibrar a balança comercial e compensar a liberalização das importações. O editorial do caderno Agrofolha afirma que "Os

\footnotetext{
${ }^{81} \mathrm{http} / / /$ www1.folha.uol.com.br/fsp/1994/1/18/agrofolha/2.html. Consulta em 05/02/2011.

${ }^{82} \mathrm{http}: / /$ www1.folha.uol.com.br/fsp/1994/5/01/caderno_especial/30.html. Consulta em 05/02/2011.
} 
representantes do agrobusiness, cadeia responsável hoje por mais de $30 \%$ do PIB nacional, vêm conquistando maior influência nas decisões da política agrícola ${ }^{83}$ ".

Naquele período era negociada a Rodada do Uruguai do GATT (General Agreement on Trade and Tariffs), que representou o primeiro passo para a criação posterior da Organização Mundial do Comércio (OMC). O artigo de Luiz Antonio Pinazza, "Desafios e lições com o fim da Rodada Uruguai", publicado em 29 de março de 1994, observa que "Pouco tem sido comentado sobre o assunto no Brasil, provavelmente pelo alto grau de fechamento da nossa economia". Ao reclamar do suposto "fechamento da nossa economia", o autor revela sua opinião sobre a necessidade de maior abertura comercial, o que, segundo ele, teria como protagonista o "agrobusiness nacional, que possui alta competitividade internacional ${ }^{84 "}$.

O argumento de Pinazza é bastante conhecido e tem sido repetido com frequência por porta-vozes do agronegócio. $\mathrm{O}$ autor reclama da "resistência das nações ricas para manter o elevado subsídio e protecionismo em seus complexos agroindustriais". Ao mesmo tempo em que ataca o "protecionismo dos países ricos", Pinazza conclui que no Brasil "por absoluta falta de política agrícola, o campo sofreu abrupta descapitalização”. A razão para a crise no campo brasileiro, segundo ele, seria justamente a abertura de seu mercado agrícola: "Com a liberalização dos mercados internos, tivemos intempestivas importações de grãos, carnes e produtos lácteos subsidiados na origem. A triticultura e a cotonicultura nacional foram duramente castigadas. Somente no algodão, mais de 200 mil brasileiros perderam emprego." A incoerência no texto se repete, quando a conclusão volta a criticar a política protecionista:

Evidentemente, não sobram motivos para o Brasil discordar do nível brutal de protecionismo com que o agrobusiness é tratado pelos países desenvolvidos. Mas é imprescindível entender as razões pelo qual isto é feito. E até aprender

\footnotetext{
${ }^{83} \mathrm{http}: / /$ www1.folha.uol.com.br/fsp/1994/5/01/caderno_especial/30.html. Consulta em 07/02/2011.

${ }^{84} \mathrm{http} / / /$ www1.folha.uol.com.br/fsp/1994/5/01/caderno_especial/30.html. Consulta em $07 / 02 / 2011$.
} 
que a vitalidade econômica de uma nação depende, em muito, do fortalecimento do mercado interno (Folha de São Paulo, 29/03/1994) ${ }^{85}$.

Fica a impressão de que os ideólogos neoliberais não conseguem se decidir. Afinal, querem o fim dos subsídios, a liberalização dos mercados nos países "ricos" e a negociação de acordos de "livre" comércio ou defendem uma política agrícola que priorize o mercado interno, sem abrir mão da defesa do apoio estatal para o agronegócio? A confusão no discurso neoliberal esconde a inevitabilidade da criação de impasses neste tipo de acordo comercial, que só se resolveriam se os países centrais deixassem de proteger suas economias, o que só os repetidores do slogan contra os malvados subsídios dos países ricos parecem acreditar. A possibilidade mais provável é sempre de que os países periféricos se submetam às regras estabelecidas nestes espaços multilaterais.

A corrente de pensamento contrária ao discurso neoliberal pode ser identificada na análise da economista Maria da Conceição Tavares, através de um artigo intitulado "Feliz ano velho para o país do futuro", publicado em 2 de janeiro de 1994. A autora utiliza o termo "agrobusiness" a partir de uma perspectiva de crítica ao "grande capital agrário" e em defesa da reforma agrária, afirmando que: "A 'grande empresa capitalista' continua usando o latifúndio e relações de trabalho supostamente 'pré-capitalistas' para avançar nos grandes negócios de gado, extração de madeira, agrobusiness e finalmente, como sempre, valorização patrimonial das terras". O artigo chama a atenção para o êxodo rural, que é acompanhado por uma crescente desigualdade econômica. Segundo Tavares, a crescente pobreza urbana é parte de um processo de "modernização" próprio do neoliberalismo, que aprofunda a precariedade do trabalho em nome da "estabilização" econômica:

Mais da metade da pobreza contemporânea foi depositar-se nas grandes metrópoles, num movimento migratório espantoso que realizou em 40 anos uma mudança na demografia econômica que levou 80 anos para ocorrer nos EUA e mais de 200 nas antigas "civilizações camponesas" europeias (Folha de São Paulo, 02/01/1994).

Em 1995 a Folha de São Paulo continua a usar o termo "agrobusiness" (com grafia errada), que aparece 19 vezes no jornal. A posição expressa nos artigos mantém a

\footnotetext{
${ }^{85}$ http://www1.folha.uol.com.br/fsp/1994/3/29/agrofolha/4.html. Consulta em 07/02/2011.
} 
defesa da agricultura extensiva e da liberalização comercial. Em 31 de outubro, José Eli da Veiga publica o artigo "Lobby do açúcar deve manter privilégios na nova lei agrícola", ${ }^{86}$ referindo-se aos produtores nos Estados Unidos. O título do texto demonstra uma crítica ao "protecionismo" e aos subsídios do governo estadunidense em relação a sua produção agrícola.

Ao mesmo tempo em que se constrói a ideia dos "países ricos" como "vilões protecionistas", o lobby ruralista brasileiro volta a negociar rolagens de dívidas com o governo; uma prática que ocorreu historicamente e continua vigente. A matéria de 1 de julho revela a pressão deste lobby doméstico:

FHC recebeu em seu gabinete 14 lideranças rurais, entre presidentes de cooperativas, sindicatos e empresas do agrobusiness. Segundo Roberto Rodrigues, presidente da Sociedade Rural Brasileira, a reunião foi convocada pelo próprio presidente. (...)As lideranças e o presidente decidiram formar uma comissão para analisar os problemas do setor, como o endividamento e a queda de renda. Segundo os líderes, FHC abriu a reunião reconhecendo que a agricultura está pagando caro pela estabilização da economia. (...) O presidente, segundo os líderes rurais, ficou de apresentar aos governadores uma proposta de trocar a redução do ICMS para produtos da cesta básica, insumos e produtos de exportação pela rolagem da dívida (Folha de São Paulo, 01/07/1995 ${ }^{87}$ ).

No dia 2 de julho de 1995, o jornal publica o artigo intitulado "Vilões ou heróis?", de Francisco Graziano, que exprime a ideologia em defesa de subsídios estatais para o agronegócio. O texto inicia com uma contestação da ideia de que o Brasil seria "o celeiro do mundo", pois, segundo o autor, isso seria um "mito". Ele afirma que:

$\mathrm{Na}$ verdade, a prática da agricultura moderna em zonas tropicais, como a brasileira, mostra enormes dificuldades para ser produtiva, rentável e sustentável. Tecnicamente, os solos tropicais são ácidos e frágeis. Com o cultivo seguido, a fertilidade se esvai, os adubos se perdem e a erosão aparece ameaçadora. As pragas e doenças são, por aqui, quase incontroláveis, tornando os agrotóxicos pouco eficientes. Os ecossistemas tropicais são mais complexos, mais suscetíveis à desequilíbrios ecológicos graves (Folha de São Paulo, 02/07/1995) ${ }^{88}$.

\footnotetext{
${ }^{86}$ http://www1.folha.uol.com.br/fsp/1995/10/31/agrofolha/8.html. Consulta em 7/2/2011.

${ }^{87}$ http://www1.folha.uol.com.br/fsp/1995/7/01/brasil/44.html. Consulta em 7/2/2011.

${ }^{88}$ http://www1.folha.uol.com.br/fsp/1995/7/02/dinheiro/4.html. Consulta em 7/2/2011.
} 
A partir desse argumento, Graziano defende uma maior "compreensão" com os "agricultores verdadeiros", que segundo ele "usam tecnologia adequada para produzirem o alimento e as matérias-primas que suprem as cidades e as indústrias, não recebem da sociedade a valorização devida". Em defesa deste setor, que seria mal interpretado por "idéias confusas [que] contaminam a mídia e provocam julgamentos equivocados", Graziano avalia que a discussão sobre o financiamento rural passa a impressão de que os agricultores seriam "malandros que buscam ganhar dinheiro à custa do pobre contribuinte ${ }^{89,}$.

O artigo justifica a necessidade de apoio estatal para o agronegócio a partir de dados sobre o aumento da oferta de alimentos que, segundo o autor, teria gerado uma queda nos preços combinada com a elevação do custo de insumos e máquinas. Com base em tal argumento, Graziano afirma que:

Esse movimento perverso dos preços penalizou gravemente os agricultores. Em alguns casos, a perda de renda é de $70 \%$. Na média, quase $30 \%$ de queda. (...) A população mais pobre dá graças a Deus -ou ao Real- pois hoje pode comprar mais comida. (...) Mas tem o outro lado da moeda. O setor agropecuário mergulhou numa crise que está provocando enorme inadimplência junto aos bancos, cooperativas e indústrias e insumos (Folha de São Paulo,02/07/1995).

Este trecho revela a incoerência do pensamento neoliberal, pois os dados apresentados no próprio artigo mostram que "os juros do crédito rural são negativos: menos 4\%". Ao mesmo tempo, Graziano defende "uma renegociação das dívidas" para o "segmento profissional da agricultura" ou para o setor identificado com as "lideranças do agrobusiness", que são classificadas no texto como "heróis". Na avaliação do autor, estes devem ser diferenciados de "especuladores de terras e latifundiários". Com este tipo de discurso, Graziano tenta criar a impressão de que haveria um setor agrícola "moderno" do "agrobusiness", que estaria em oposição a outro "atrasado" identificado através de sua relação com a bancada ruralista no Congresso Nacional. A proposta do texto pode ser resumida na seguinte afirmação: "Enquanto a sociedade continuar confundindo nunca se formará uma opinião pública favorável às suas reivindicações,

${ }^{89}$ http://www1.folha.uol.com.br/fsp/1995/7/02/dinheiro/4.html. Consulta em 7/2/2011. 
mesmo que justas. Essa deficiência do marketing rural é trágica para o desenvolvimento do setor ${ }^{90 "}$.

Parece que o objetivo do artigo seria suprir essa suposta "deficiência do marketing rural" no sentido de propagar a ideologia que defende o modelo agrícola do chamado agribusiness. As próprias afirmações dos defensores desse setor mostram a constante necessidade de renegociação de dívidas, já baseadas em juros negativos, o que nos leva a concluir que a crise estrutural deste modelo só se sustenta através de subsídios do Estado, ou seja, de apropriação de mais-valia social.

Neste contexto, observamos que o termo agribusiness (ou "agrobusiness", como era frequentemente utilizado) é relacionado à imagem do que seria moderno e estaria associado à necessidade de novas tecnologias e de integração com setores industriais. Na reportagem intitulada "Formação deixa de ser só agrária" fica clara a relação entre os termos agribusiness e cadeia produtiva:

O engenheiro agrônomo não é mais aquele profissional que trabalha exclusivamente na terra. Sua formação abrange técnicas de adubação, mecanização, planejamento e comercialização da safra. Atualmente, um importante mercado de trabalho é o 'agrobusiness' (setor que alia produção, industrialização e venda de produtos agrícolas) (Folha de São Paulo, 9/10/1995).

Em 1996 a palavra agronegócio aparece somente uma vez na Folha de São Paulo, em um artigo intitulado "A laranja explosiva" 91 de Evaristo Marzabal Neves, diretor da ESALQ (Escola Superior de Agricultura Luiz de Queiroz). O título se refere a uma crítica aos protestos que os produtores de laranja em São Paulo organizaram contra a queda do preço no mercado internacional, principalmente em decorrência de um maior grau de produtividade na Flórida. Neves defende que "é preciso pôr ordem na corte". Segundo ele, "A desorganização e a desestabilização atuais ferem um dos setores mais dinâmicos do agronegócio brasileiro, e a citricultura paulista, que se orgulha de seu elevado poder competitivo internacional, certamente recolherá os respingos amargos e azedos da explosiva laranja". Como solução para um problema que decorre do próprio modelo agrícola adotado pelo Estado brasileiro, Neves propõe como solução a "arte de

\footnotetext{
${ }^{90} \mathrm{http} / / / w w w 1 . f o l h a . u o l . c o m . b r / f s p / 1995 / 7 / 02 /$ dinheiro/4.html. Consulta em 7/2/2011.

${ }^{91}$ http://www1.folha.uol.com.br/fsp/1996/7/20/dinheiro/9.html. Consulta em 7/2/2011.
} 
negociar" e afirma: "Negociação é a palavra-chave no comércio mundial, mas saber negociar, antes de tudo, é arte. É dominar a informação, as condições atuais e previsões de oferta e demanda mundiais e internas e, acima de tudo, o conhecimento das políticas econômicas domésticas e externas e das regras de mercado". Porém, não fica claro o que realmente estaria em jogo nessa negociação, já que o próprio processo de formação de monopólios agroindustriais, combinado ao monopólio da terra no Brasil e a um modelo agrícola dependente da demanda externa, gerou maior vulnerabilidade no setor.

Em 1997 a palavra agronegócio aparece três vezes na Folha de São Paulo. O primeiro artigo, de Evaristo Marzabal Neves, tem como título "Olhai a agricultura"92. Esse texto é emblemático por sua defesa de subsídios para o setor, com o argumento de que os produtos agrícolas representariam a âncora do Plano Real para conter a inflação. Segundo Neves, "Seria possível nos apoiarmos em outros indicadores, que revelariam que a agricultura e a cadeia agroalimentar 'seguraram a barra' da cultura inflacionária do país e representaram, efetivamente, a âncora (verde) do Plano Real”. O conteúdo do artigo visa propagar a ideia de que haveria uma "dívida" da sociedade e do governo com o agronegócio, como mostra o seguinte trecho:

E olhem que, no balanço sobre as ações propostas para cinco metas prioritárias (estabelecidas no documento 'Mãos à Obra, Brasil', de 94), o governo federal ainda está devendo à agricultura e, por extensão, à cadeia agroalimentar. Para o tempo que resta ainda, visando a efetivação da proposta de governo, é de acreditar que o setor agroalimentar poderá corresponder ainda mais se atendido em suas reivindicações socioeconômicas (Folha de São Paulo, 01/10/1997).

O conceito de cadeia produtiva, travestido de agronegócio, é utilizado para reivindicar que o governo adote "ações sistêmicas" para atender a "complexidade da cadeia agroalimentar" e garantir sua "capacidade competitiva". Este tipo de jargão é usado para justificar a continuidade de acesso a crédito, subsídios e outros tipos de vantagens estatais para o agronegócio, como mostra o seguinte trecho:

A agricultura já não é mais vista como um setor isolado (dentro da porteira), mas fortemente interligado com os demais setores da economia. Mundialmente, é reconhecido que o agronegócio é a mais longa cadeia de qualquer economia internacional. É sabido, também, que ações pontuais para o setor não têm obtido o resultado desejado e têm eficácia comprometida. Consciente disso, o governo

\footnotetext{
${ }^{92}$ http://www1.folha.uol.com.br/fsp/1997/1/10/dinheiro/4.html. Consulta em 8/2/2011.
} 
federal vem entendendo que a complexidade da cadeia agroalimentar requer ações sistêmicas, que exigem atenções e correções em todos os elos, diante do pressuposto de que 'nenhuma corrente é mais forte do que seu elo mais fraco'. É este, afinal, que dita a capacidade competitiva da cadeia e que acaba comprometendo a eficiência de outros elos. Nesse sentido surge, em tão boa hora, o Fórum Nacional da Agricultura, coordenado por Roberto Rodrigues (pela iniciativa privada) e por Ailton Barcelos, secretário executivo do Ministério da Agricultura (Folha de São Paulo, 01/10/1997).

A citação acima revela que o lobby exercido pelo agronegócio é organizado através de espaços políticos e instituições de classe. No sentido de investigar o contexto no qual estão inseridos os porta-vozes do agronegócio, verificamos que existem diferentes tipos de organizações do setor no Brasil, com o intuito de articular determinados grupos econômicos, de exercer pressão sobre órgãos governamentais, de buscar representação no Congresso Nacional, de fazer a luta ideológica e exercer repressão contra movimentos sociais no campo. De acordo com um estudo sobre o perfil destas organizações, haveria uma diferenciação entre:

(1) aquelas criadas com o objetivo de fortalecimento do "setor" geralmente por cultura ou por segmento econômico - é o caso da ÚNICA [União da Agroindústria Canavieira de São Paulo], APROSOJA [Associação dos Produtores de Soja do Estado do Mato Grosso], AMPA [Associação Matogrossense dos Produtores de Algodão] e ABAG [Associação Brasileira de Agribusiness] e Departamento de Agronegócio da FIESP (DEAGRO); (2) entidades criadas em resposta a pressão de movimentos de luta por terra e em decorrência da instituição de políticas públicas mais diretamente ligadas à questão fundiária - é a situação da APR-MT [Associação dos Produtores Rurais de Mato Grosso] e do MNP [Movimento Nacional dos Produtores]; (3) e finalmente as entidades historicamente constituídas - Sindicato patronal (sistema CNA), Sociedade Rural Brasileira, Organização das Cooperativas Brasileiras (BRUNO; CARNEIRO \& SEVÁ, 2008, p. 19).

Este tipo de estrutura organizacional do agronegócio tem sido eficiente para garantir a continuidade de acesso a créditos subsidiados, rolagem de dívidas e incentivos fiscais. Um destes incentivos foi estabelecido pela chamada Lei Kandir que, a partir de 1996, isentou o ICMS (Imposto sobre Circulação de Mercadorias e Serviços) para a exportação de produtos primários brasileiros.

A reportagem intitulada "Indústria reduz processamento de soja" mostra os efeitos desta medida: "Antes da lei, a soja em grão pagava $13 \%$ de ICMS, o farelo $11,1 \%$, e o óleo $8 \%$ ". A matéria relata que a isenção de impostos, que inicialmente beneficiava apenas os produtos não processados, gerou uma queda na produção de óleo de soja. Por esta razão, o então secretário-executivo da Câmara do Comércio Exterior 
José Frederico Álvares afirma em entrevista que "o óleo de soja foi incluído na lista de produtos que recebem financiamento para a exportação (Folha de São Paulo, $10 / 01 / 1997)^{93}$.

Diferentes formas de subsídios estatais para a agricultura extensiva ganham força naquela época, em plena era "neoliberal". Um dos defensores do agronegócio é Luiz Moricochi, engenheiro agrônomo e economista da Escola Superior de Agricultura "Luiz de Queiroz" (ESALQ - USP), identificado pela empresa de consultoria The Coffee Traveler como "um fundamentalista, ou seja, que se baseia nos fundamentos do mercado ${ }^{94 "}$. Apesar de ser conhecido por adotar uma visão liberal ortodoxa, Moricochi chama atenção para a situação de crise e desvalorização de produtos agrícolas no mercado futuro, em seu artigo "Produtor deve ficar atento à evolução do mercado" publicado na Folha de São Paulo em 29 de janeiro de $1997^{95}$. O exemplo utilizado é a crise gerada na produção de café que, em 1992, teve um custo de produção de US\$80 por saca e foi vendido a US\$40 por saca. O autor defende maior apoio estatal para o setor e afirma que:

Como estudioso de economia e política cafeeira, lembro, com indignação, a maneira insensível com que as angústias dos cafeicultores eram tratadas pelas autoridades federais da época. (...) Medidas emergenciais deveriam ter sido tomadas na ocasião para evitar o sucateamento de parte do parque cafeeiro nacional (Folha de São Paulo, 29/01/1997).

Em outro trecho do artigo, Moricochi admite que os movimentos especulativos do mercado de commodities, assim como o monopólio da comercialização, geram uma situação crítica especialmente para a pequena agricultura: "Pequenos produtores precisam ter ainda uma preocupação adicional: diversificar suas atividades (dentro de certos limites, é claro) visando a obtenção de renda mais estabilizada.” Ao final, o autor prevê uma "nova fase de preços baixos" e cita como uma das causas "a ação dos

\footnotetext{
${ }^{93}$ http://www1.folha.uol.com.br/fsp/1997/9/02/agrofolha/4.html. Consulta em 10/02/2011.

${ }^{94} \mathrm{http}: / /$ coffeetraveler.net/tendencias-de-precos-de-cafe-luiz-moricochi/. Consulta em 31/05/ 2010.

${ }^{95}$ http://www1.folha.uol.com.br/fsp/agrofolh/fa290108.htm. Consulta em 31/05/ 2010.
} 
grandes fundos de 'commodities', que, mesmo não tendo interesse direto no mercado de café, chegam a controlar até $70 \%$ de seus contratos futuros ${ }^{96}$."

Em 1998, o termo agronegócio aparece oito vezes na Folha de São Paulo. O primeiro artigo naquele ano, publicado no dia 17 de janeiro, é de Evaristo Marzabal Neves, diretor da Escola Superior de Agricultura Luiz de Queiroz (ESALQ). No texto intitulado "A agricultura e a lição de casa" Neves repete a interpretação de que o agronegócio seria a "âncora” da estabilidade econômica:

Início de ano, balanço geral. Particularmente, cada setor da economia contabiliza ativos e passivos e seja o que Deus quiser. Nesse cenário do Plano Real, a agricultura e o agronegócio exercitam também o seu balanço do ano que acabou. Indicadores econômicos e estimativas evidenciam que o mundo agrícola brasileiro vem "segurando o rojão" na dura missão da estabilidade econômica (Folha de São Paulo, 17/01/1998).

A afirmação acima se baseia em dados que indicam que o aumento no preço dos alimentos em 1997 foi menor do que a taxa de inflação. Segundo o autor, em São Paulo a taxa de inflação foi de $4,82 \%$ enquanto os alimentos tiveram alta de $3,60 \%$. Outro argumento diz respeito ao peso do agronegócio na balança comercial, que teve resultado negativo naquele ano. "As previsões iniciais sinalizavam um déficit que ultrapassaria US\$ 12 bilhões em 97. Para surpresa geral, deve ter ficado em torno de US\$ 8,5 bilhões”, diz o artigo. Para exaltar o agronegócio, Nevez sustenta que a situação poderia ser pior: "Outra vez, no lado das exportações, produtos do agrobusiness brasileiro foram responsáveis por um fluxo comercial negativo menor". Com esse argumento, o texto defende que para garantir o que chama de "desenvolvimento sustentado e equilibrado, crescimento econômico e bem-estar social", seriam necessárias "políticas agrícolas de médio e longo prazos, que privilegiarão, mediante vantagens comparativas e competitivas, uma agricultura profissional, eficiente, capitalizada ${ }^{97 "}$. Novamente observamos que, apesar da crise e do déficit comercial, se reforça a noção de que o agronegócio, caracterizado como "agricultura profissional, eficiente, capitalizada" deve receber privilégios.

Em 31 de março de 1998, uma reportagem sobre o evento chamado "Agrishow

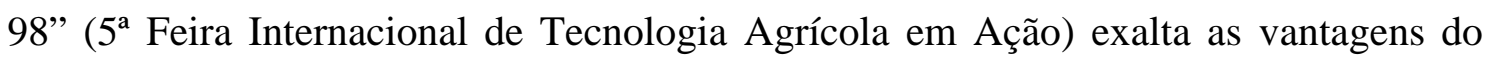

\footnotetext{
${ }^{96} \mathrm{http} / / /$ www1.folha.uol.com.br/fsp/agrofolh/fa290108.htm. Consulta em 31/05/ 2010.

${ }^{97}$ http://www1.folha.uol.com.br/fsp/dinheiro/fi170112.htm. Consulta em 30/05/ 2010.
} 
setor que, segundo a texto, "espera movimentar cerca de US\$ 600 milhões". O jornal cita como fonte Antonio Herminio Pinazza, então diretor executivo da Associação Brasileira de Agribusiness (Abag): "Para Pinazza, com a globalização e a estabilidade econômica, o agrobusiness brasileiro se transformou no maior negócio do país. O setor representa hoje $40 \%$ das exportações brasileiras e 35\% do PIB (soma das riquezas produzidas no país)". A matéria traz também a opinião de Persio Luiz Pastre, que era vice-presidente da Associação Nacional dos Fabricantes de Veículos Automotores (Anfavea), segundo a qual não iriam faltar financiamentos para o agronegócio: "o agricultor brasileiro tem disponível o que há de mais avançado em termos de tecnologia. Este ano, o agricultor contará com dois bancos (Banco do Brasil e Bradesco) para financiamentos". 98

Em contraste com a imagem de eficiência do agronegócio, chamado de "maior negócio do país”, no dia 13 de outubro de 1998 a Folha de São Paulo noticia nova prorrogação de dívidas: "O Ministério da Agricultura encaminhou para a aprovação do Conselho Monetário Nacional proposta prorrogando por mais dez anos as dívidas securitizadas com vencimento este mês ${ }^{99 "}$.

Naquele período, o termo "agrobusiness" (com grafia errada, mas inspirado na palavra agribusiness em inglês) passa a ser adotado oficialmente nas definições de políticas públicas. A matéria de 25 de agosto de 1998 anuncia a criação do Conselho Nacional do Agronegócio (Conagris), com o objetivo de "promover a modernização de toda a cadeia produtiva do agrobusiness, melhorar a competitividade dos produtos brasileiros no exterior e propor medidas para reduzir o chamado custo Brasil”. Segundo a reportagem, o Conagris agregaria "desde fabricantes de insumos agrícolas, passando pelos agricultores, cooperativas e bancos, até as indústrias de alimentos". Estes segmentos demandavam que o governo cumprisse "10 bandeiras do agronegócio". Algumas destas "bandeiras" foram descritas como acesso a fontes "alternativas" para a captação de recursos, "modernização" da comercialização, redução de impostos e privatização dos portos ${ }^{100}$.

\footnotetext{
${ }^{98}$ http://www1.folha.uol.com.br/fsp/agrofolh/fa31039809.htm. Consulta em 30/05/ 2010.

${ }^{99} \mathrm{http}: / /$ www1.folha.uol.com.br/fsp/agrofolh/fa13109804.htm. Consulta em 30/05/ 2010.

${ }^{100}$ http://www1.folha.uol.com.br/fsp/agrofolh/fa25089807.htm. Consulta em 30/05/ 2010.
} 
O pensamento neoliberal que imperava nos meios de comunicação combinava o discurso em defesa da "modernização" da agricultura com a necessidade de expandir as privatizações. No artigo "Privatizando a gestão da agricultura brasileira"101", publicado em 15 de setembro de 1998, Benjamin Steinbruch, que na época era presidente dos conselhos de administração da Companhia Siderúrgica Nacional, da Metropolitana e da Vale do Rio Doce, argumenta que "só com um aumento expressivo das exportações o país conseguiria reduzir a sua dependência dos humores dos mercados internacionais". Entretanto, o texto não esclarece como um país que prioriza o monocultivo para exportação poderia se tornar "independente" em relação às oscilações no mercado internacional.

A continuação do artigo sugere que "Os tempos do Brasil "essencialmente agrícola', com sua economia fortemente dependente do algodão, do milho, da cana-deaçúcar e do café, ficaram para trás". Porém, como forma de superação destes "tempos", o autor propõe uma "grande arrancada" baseada em "alicerces", que caracteriza como a suposta "abundância" de terra e água no Brasil. Ora, como deixar de ser um país "essencialmente agrícola" (supostamente "atrasado") se os fatores que permitiriam essa "grande arrancada" estariam baseados na expansão da apropriação de recursos naturais como terra e água? Ainda de acordo com Steinbruch, a ideia de "modernidade" estaria associada ao desenvolvimento de tecnologias "eficientes". Ele afirma que:

A terra é o principal insumo, realmente. Mas não se avançará um milímetro se não houver conhecimento e educação que permitam ao pequeno ou ao grande produtor tirar partido das novas tecnologias e dos avanços da genética e ampliar a eficiência dos seus recursos humanos e materiais visando aumentar a produtividade e melhorar as condições de competição (Folha de São Paulo, 15 de setembro de 1998).

$\mathrm{O}$ autor utiliza o termo agribusiness associado à noção de cadeia produtiva. A fórmula encontrada para explicar o sistema de cadeia produtiva é bastante conveniente no sentido de inflar o peso do agronegócio no Produto Interno Bruto (PIB) e, assim, justificar maiores subsídios públicos para o setor. O artigo utiliza este argumento: "A produção agrícola superou os $\mathrm{R} \$ 80$ bilhões no ano passado, mas o chamado "agribusiness", que engloba produtos e serviços diretamente ligados à atividade, superou R \$ 300 bilhões, respondendo por cerca de 1/3 do nosso PNB”.

${ }^{101}$ http://www1.folha.uol.com.br/fsp/dinheiro/fi15099828.htm. Consulta em 03/06/2010. 
A visão de Steinbruch é um pouco original se comparada à de outros colunistas que defendem o aumento de subsídios estatais para o agronegócio. Para ele, "É preciso que a visão da agricultura seja empresarial e privada. Subvenções, incentivos fiscais, vantagens oficiais se mostraram incapazes de alavancar a agricultura brasileira ${ }^{102}$,. O autor admite, portanto, que apesar de contar com recursos públicos, a agricultura extensiva não consegue superar uma situação de crise. Como conclusão do artigo, Steinbruch exalta os mecanismos de negociação de commodities chamados de "mercados futuros" com o propósito de "privatizar a gestão dos recursos". O texto defende ainda que seria preciso "romper" as barreiras dos países "protecionistas" e vê a privatização de serviços públicos como solução para saldar o que chama de "dívida social". Este trecho sintetiza algumas de suas propostas:

$\mathrm{O}$ produtor poderia vender o fruto de seu trabalho antes mesmo de plantar a semente, usando as modernas técnicas de compra e venda "futura", que são o sustentáculo dos mercados internacionais. Vamos esquecer a obrigatoriedade da intermediação do Estado na viabilização da produção agrícola. (...) Precisamos ser agressivos e modernos inclusive na ação diplomática que nem sempre consegue enfrentar as barreiras protecionistas com que as grandes economias dificultam a entrada de produtos brasileiros. Na indústria e nos serviços o governo avançou em um programa de privatização que está contribuindo para aprimorar as condições de competição de importantes empresas e libera recursos oficiais para investimentos destinados a resgatar a nossa dívida social. $\mathrm{Na}$ agricultura não há grandes empresas oficiais à venda. Vamos adiante, assim mesmo, privatizando a gestão da agricultura brasileira e, dessa forma, ajudando a construir um país mais rico e socialmente mais justo (Folha de São Paulo, 15 de setembro de $1998^{103}$ ).

Outro texto emblemático, publicado em 2 de outubro de 1998, é o artigo intitulado "Subsídios e sobrevivência"104 de João Carlos de Souza Meirelles, que se define como "pecuarista e colonizador, secretário de Agricultura e Abastecimento de São Paulo e presidente licenciado do Conselho Nacional da Pecuária de Corte". Meirelles traça um quadro que inclui dados sobre os subsídios agrícolas dos países membros da OCDE (Organização para Cooperação e Desenvolvimento Econômico), que chegariam a US\$ 335 bilhões, ao mesmo tempo em que reconhece o movimento especulativo do mercado internacional de commodities e seus impactos no Brasil:

\footnotetext{
${ }^{102}$ http://www1.folha.uol.com.br/fsp/dinheiro/fi15099828.htm. Consulta em 03/06/2010.

${ }^{103}$ http://www1.folha.uol.com.br/fsp/dinheiro/fi15099828.htm . Consulta em 03/06/2010.

${ }^{104}$ http://www1.folha.uol.com.br/fsp/dinheiro/fi02109816.htm. Consulta em 03/06/2010.
} 
Os preços mundiais de muitos produtos exportados pelo Brasil estão em queda. Segundo estudo da Unctad, órgão da ONU que trata de assuntos de comércio, de dezembro de 1997 a abril, os preços das commodities haviam caído 4,5\%. Nessa baixa, ressaltamos as perdas no valor de café $(15,3 \%)$, cacau $(0,6 \%)$, açúcar $(25,1 \%)$ e carne bovina $(3,1 \%)$ (Folha de São Paulo, 02/10/1998).

A resposta encontrada para tal situação de instabilidade de preços no mercado internacional seria demandar proteção estatal, sob o seguinte argumento: "A renda do produtor brasileiro precisa de proteção. Segundo a Organização das Cooperativas Brasileiras, só esse setor perdeu $26 \%$ em exportações agrícolas no primeiro semestre do ano, faturando US\$ 423,8 milhões, contra US\$ 533,9 milhões no ano passado”. O artigo exalta a "modernização e profissionalização" do agronegócio e propõe que o Brasil aposte nas negociações da Organização Mundial do Comércio (OMC) para aumentar suas exportações, acreditando que os países centrais pudessem fazer concessões em relação à proteção de sua própria agricultura: "Um recente estudo da Confederação Nacional da Agricultura indica que o Brasil poderia aumentar suas vendas de agroprodutos aos Estados Unidos em US\$ 5 bilhões se esse país reduzisse as barreiras não-alfandegárias, que restringem a venda de 80 diferentes produtos". No sentido de obter este resultado, Meirelles propõe:

(...) exigir de governos estrangeiros e organismos internacionais a redução das barreiras ao livre comércio; instalar adidos de agronegócio nas embaixadas e foros internacionais; construir e formar negociadores multidisciplinares e especializados em agronegócio (Folha de São Paulo, 02/10/1998).

Este trecho sugere que o autor defende a "liberalização" comercial a partir de medidas baseadas na intervenção estatal e na criação de estruturas governamentais específicas para cumprir tal tarefa, com o objetivo de organizar a política externa em função do lobby do agronegócio. De certa maneira, este tipo de política se manteve ao longo dos anos, mesmo com os repetidos e previsíveis "fracassos" das negociações, principalmente no âmbito da OMC.

\section{A ideologia do livre comércio}

Desde a sua criação em 1995, o principal papel da OMC tem sido expandir seu poder de regulamentação de políticas comerciais em 147 países. Apesar de difundir a ideologia do livre comércio, a OMC possui uma complexa estrutura de normas utilizadas para estimular a formação de monopólios no acesso a mercados internacionais. A abrangência dos acordos contidos na OMC vai além de temas 
relacionados ao comércio internacional, incluindo propriedade intelectual e privatização de setores de serviços.

Apesar da propaganda do Estado mínimo difundida principalmente durante a década de 1990 no o período conhecido como neoliberal, o papel central dos Estados nacionais continuou a ser a transferência de mais-valia social para o setor privado. Podemos concluir, então, que o chamado Estado mínimo nunca existiu para o capital. O que ocorreu foi o desmonte das políticas que constituíram o chamado Estado de bemestar social, em um processo de ampliação de monopólios privados.

A expansão de uma economia agrícola de monopólio, associada à chamada "liberalização" comercial, é descrita pelo então diretor-presidente da Embrapa Alberto Duque Portugal no artigo "A cadeia do leite no Brasil ${ }^{105 ", ~ p u b l i c a d o ~ e m ~} 15$ de dezembro de 1998. O autor alerta que a "abertura econômica" e "um forte processo de ajustamento estrutural" geraram “concentração de produção". De acordo com o texto, os impactos desta política teriam:

(...) excluído muitos agentes econômicos, principalmente pequenos produtores, com poucas alternativas dentro ou fora do setor. Esse ajustamento rápido está trazendo um custo social alto, representado pela saída de pequenos produtores do mercado, com a redução do emprego rural e do número de pequenas e médias indústrias que compõem o agronegócio do leite. (...) refletido na falta de emprego, na renda e na miséria (Folha de São Paulo, 15/12/1998).

Na opinião de Portugal, a alternativa não seria mudar esta política, mas simplesmente "fazê-lo de forma um pouco mais lenta, reduzindo os custos sociais". O exemplo utilizado no texto é a indústria do leite, porém o autor reconhece que em todo o setor agrícola ocorreu o impacto da política conhecida como dumping, que ele descreve como: "abertura para importação a preços que estão abaixo do custo de produção". O artigo conclui que, "Do ponto de vista puramente econômico, o ajuste estrutural acelerado pode fazer sentido, porque está maximizando o uso da capacidade ociosa da agricultura brasileira. Todavia, seu custo social é alto e pode levar a um processo de desenvolvimento desequilibrado". Este texto exemplifica como o discurso neoliberal pode conter um viés desenvolvimentista, já que ambas correntes defendem as chamadas políticas de livre comércio para a agricultura.

${ }^{105}$ http://www1.folha.uol.com.br/fsp/dinheiro/fi15129804.htm. Consulta em 10/05/2010. 
A crise entre produtores de leite no Brasil é descrita também em uma reportagem publicada em 15 de junho de 1999, que confirma os seguintes números: "Cem mil produtores desistiram do leite ${ }^{106 "}$. Segundo a matéria, “A não adaptação às mudanças e inovações aceleradas da pecuária de leite levou cem mil produtores brasileiros a deixarem a atividade nos dois últimos anos." Os dados foram comentados pelo professor Luís Fernando Laranja, da Faculdade de Medicina Veterinária da Universidade de São Paulo, que afirma:

'O desajuste entre os elos que compõem o agronegócio proporciona uma variação violenta nos preços pagos ao leite, o que torna o planejamento impossível'. O professor reconhece também que 'Houve uma enxurrada de leite importado nos dois últimos anos, e a indústria pagou o que queria ao pecuarista (...). Some-se a isso, a chegada de novas tecnologias, como os tanques de resfriamento do leite na fazenda, que contribuíram para deixar à margem os pequenos' (Folha de São Paulo, 15/06/1999).

As explicações mais comuns para a exclusão de pequenos e médios produtores da cadeia do agronegócio são sua falta de acesso ou dificuldade de adaptação a novas tecnologias e sua suposta incapacidade de cumprir com normas sanitárias. Porém, como analisamos nos capítulos anteriores, o próprio movimento de crise-acumulação do capital gera um processo de formação de monopólios que elimina os "elos" mais "fracos" da cadeia produtiva, ou seja, os segmentos menos produtivos no sentido de utilizar uma maior percentagem de trabalho vivo em relação ao capital constante. Marx explica que:

É essa separação entre condições de trabalho aqui e produtores lá que forma o conceito de capital: inaugura-se com a acumulação primitiva (...), aparece depois como processo constante na acumulação e concentração de capital e por fim se expressa aqui como centralização de capitais já existentes em poucas mãos e como descapitalização de muitos (nisso é que agora se transforma a expropriação). Esse processo levaria em breve a produção capitalista ao colapso, se tendências contrárias não atuassem constantemente (MARX, Vol. IV, Livro III, Tomo I, 1988, p. 177).

A citação acima esclarece que, ao eliminar os "ramos mortos" (MANDEL, 1990) do processo produtivo, modifica-se a diferença que existia entre a taxa de lucro destes capitais e daqueles com maior produtividade que antes apropriavam sobrelucro com base na taxa média, gerando uma tendência geral de diminuição. É nesse sentido que Marx entendeu a queda tendencial da taxa de lucro, que se constitui em crise com a

\footnotetext{
${ }^{106}$ http://www1.folha.uol.com.br/fsp/agrofolh/fa15069913.htm. Consulta em 08/05/2010.
} 
crescente impossibilidade de valorização do capital: "A queda da taxa de lucro não nasce de uma diminuição absoluta, mas de uma diminuição relativa do componente variável do capital global, de sua diminuição comparada com o componente constante (MARX, Vol. IV, Livro III, Tomo I, 1988, P. 158).

Um dos setores do agronegócio que se caracteriza pela maior concentração de capitais é a comercialização, com grandes empresas que controlam o comércio internacional. Abordamos este tema no terceiro capítulo, que descreveu elementos da conjuntura mundial no período pós-guerra. Como vimos anteriormente, o principal negócio das grandes empresas do agronegócio é o acesso a subsídios estatais. A concorrência capitalista gera uma tendência de aumento da produtividade, entendida como o aumento do capital constante em relação ao capital variável, que demanda crescentes investimentos na agricultura. Tal processo resultou na chamada crise de superprodução ou de superacumulação. Um dos efeitos foi a geração de excedentes de grãos no mercado mundial, que ocasionou as políticas de dumping e a maior especulação nos mercados de commodities. Apesar de aparecer como um problema entre oferta e demanda, a crise de superprodução do capital tem como ponto central o processo produtivo $^{107}$.

Na década de 1990, o movimento global do capital financeiro e a especulação nos mercados futuros e de commodities são facilitados por políticas de ajuste estrutural, identificadas com o modelo econômico neoliberal. Naquele período se aprofundam as políticas de abertura comercial, que estimularam o dumping de produtos agrícolas no mercado brasileiro. A matéria de 23 de fevereiro de 1999, intitulada "Governo desmente importação de trigo dos EUA" exemplifica este cenário. O texto afirma que em 1998 o Brasil havia importado 6,4 milhões de toneladas de trigo dos Estados Unidos. Segundo a matéria, "O alimento entraria no país com um prazo de 20 anos de pagamento" o que "serviria como desestímulo à produção nacional ${ }^{108, "}$.

107 Para Marx, devemos entender a crise como "superprodução de capital, não de mercadorias individuais - embora a superprodução de capital sempre implique superprodução de mercadorias - significa, por isso, apenas superacumulação de capital. (MARX, Vol. IV, Livro III, Tomo I, 1988, p. 177).

${ }^{108}$ http://www1.folha.uol.com.br/fsp/agrofolh/fa23029910.htm. Consulta em 19/05/2010. 
A adoção de novas tecnologias, tão propagada como solução para resolver a crise na agricultura, não é capaz de evitar a queda nos índices de produtividade no Brasil, como mostra a reportagem intitulada "Cana perde produtividade na região Centro-Sul nesta safra”, publicada na Folha de São Paulo em 23 de fevereiro de 1999. Segundo a matéria, a diminuição no índice de produtividade na safra 98/99 gerou também uma renda mais baixa em relação ao ano anterior: "o faturamento da safra passada ficou em torno de $\mathrm{R} \$ 24 / \mathrm{t}$ de cana, contra $\mathrm{R} \$ 30 / \mathrm{t}$ de cana da safra de 97 ". Estes dados ilustram a incoerência da ideia de avanço e desenvolvimento interpretada como se significasse um movimento linear, não contraditório, do modo capitalista de produção rumo a um suposto patamar ideal.

Este tipo de pensamento pode ser identificado na linha editorial da Folha de São Paulo, que promove a imagem do agronegócio como gerador de divisas e desenvolvimento. No artigo "Agronegócio já é 40\% da economia”, publicado em 11 de junho de 1999, o jornalista Clóvis Rossi diz que a renda do setor em 1998 foi de R 358 bilhões, que representaria 39,7\% do Produto Interno Bruto (PIB) brasileiro. O texto traz a seguinte afirmação: "agricultura apenas é coisa do passado; hoje a palavra certa é agronegócio" que, segundo o autor "significa tudo que nasce no campo, mas ganha valor agregado (laranja, por exemplo, é agricultura; suco de laranja é agronegócio)". A matéria inclui uma entrevista com Luís Haffers, presidente da Sociedade Rural Brasileira na época, que reclama dos "subsídios concedidos pelos países ricos a seus produtores".

Como destacamos anteriormente, o discurso sobre a suposta vocação agrícola brasileira, no sentido da defesa do modelo econômico baseado no monocultivo para exportação, é reforçado repetidamente nos meios de comunicação. Outro mote frequente é o cálculo do peso do agronegócio no Produto Interno Bruto (PIB), sucessivamente estimado entre $30 \%$ e $40 \%$. Estes números reforçam a ideia de que o setor geraria desenvolvimento econômico e saldo positivo na balança comercial. Entretanto, a comparação entre o saldo comercial agrícola e os recursos investidos na produção mostra falhas nos cálculos sobre a suposta vantagem econômica do agronegócio.

A reportagem do dia 29 de dezembro de 1999, intitulada "Agronegócio segura balança, diz Pratini”, projeta a imagem do setor como âncora comercial. Em entrevista, o então ministro da Agricultura, Marcus Vinicius Pratini de Moraes, prevê que em 2000 
“o agronegócio no Brasil deverá gerar um superávit comercial de US\$ 15 bilhões”. A continuação da entrevista revela que, "Este ano, apenas esse segmento deverá apresentar um saldo positivo na balança comercial, de cerca de US\$ 12 bilhões. A balança total, de janeiro a novembro, já está com um déficit de US\$1,447 bilhão”. Se compararmos estes números com os montantes de rolagens de dívidas anunciados naquele período, fica evidente que o saldo econômico seria negativo. Por exemplo, uma matéria publicada na Folha de São Paulo em 18 de agosto de 1999 anuncia que o governo havia negociado o perdão de $\mathrm{R} \$ 18$ bilhões em dívidas do agronegócio naquele ano. Portanto, somente considerando este socorro governamental, é possível constatar que o produto do agronegócio é dívida.

Naquele momento, um dos motivos de preocupação do governo era a infecção do gado pela febre aftosa, que poderia impactar ainda mais a exportação brasileira. Na entrevista publicada em 29 de dezembro de 1999, o ministro Pratini diz esperar que "o Congresso norte-americano aprove cotas de exportação para a carne bovina brasileira", pois, segundo ele "Fizemos nossa lição de casa". A afirmação mostra que, na busca por vantagens comerciais para o agronegócio, o governo brasileiro teria a preocupação de cumprir a "lição de casa". Este tipo de discurso se baseia na ideia de que os países centrais poderiam ajudar o Brasil, principalmente se o país seguisse o receituário neoliberal.

O debate sobre as negociações em torno da liberalização do comércio mundial era frequente na pauta da mídia brasileira. Uma matéria do jornalista Clovis Rossi, membro do Conselho Editorial da Folha de São Paulo, destaca: "Seminário em São Paulo mobiliza o setor privado para discussão de negociações internacionais Agronegócio desperta para setor externo". O seminário seria uma preparação para o início das negociações da Rodada do Milênio da Organização Mundial do Comércio (OMC), que ocorreria em Seattle, nos Estados Unidos. O texto, publicado em 4 de agosto de 1999, traz a opinião de Luiz Fernando Furlan que era vice-presidente da Federação das Indústrias do Estado de São Paulo (FIESP):

Tão numeroso público se explica: o agronegócio, que já responde por 39,7\% da produção de riquezas do país (seu PIB, Produto Interno Bruto), vê nas negociações internacionais que se iniciarão no começo de dezembro, a grande chance de expandir seus mercados. Como? Se das negociações resultar, como esperam empresários e o próprio governo brasileiro, a derrubada, mesmo que parcial, do muro de proteção que os países ricos ergueram em torno de seus produtos agrícolas (Folha de São Paulo, 04/08/1999). 
A matéria cita o então secretário de Agricultura de São Paulo, João Carlos de Souza Meirelles, dizendo que "o agronegócio é a grande fronteira de geração de empregos e negócios". Outro entrevistado é o chanceler brasileiro na época, Luiz Felipe Lampreia, que expressa opinião semelhante: "a agricultura é, de longe, a principal prioridade (do Brasil) nas negociações comerciais internacionais". O conteúdo das entrevistas se repete também quando inclui reclamações contra o apoio estatal que os Estados Unidos e os países europeus concedem à sua agricultura. A reportagem destaca a expectativa de que o ministro da Agricultura, Pratini de Moraes:

(...) cobrasse, tanto da Europa como dos Estados Unidos, datas para eliminar os três tipos de proteção a seus agricultores: subsídios para exportações (só os subsídios dos EUA à sua soja representam mais que toda a renda da exportação de soja pelo Brasil); derrubada das elevadas tarifas ainda praticadas no setor; e eliminação dos esquemas de ajuda para a produção destinada ao mercado interno (Folha de São Paulo, 04/08/1999).

A probabilidade de impasse nesse tipo de negociação é levantada pelo jornalista Clovis Rossi, que destaca um ponto fundamental normalmente minimizado - as contrapartidas exigidas pelos Estados unidos e União Europeia em troca de promessas sobre a abertura de seus mercados para produtos agrícolas brasileiros - que seriam maiores concessões do Brasil para a entrada de empresas multinacionais em setores industriais, financeiros e de serviços, além da aceitação de acordos de propriedade intelectual. Rossi indica que:

Ficou faltando apenas dizer o que o Brasil está disposto a dar em troca da abertura do mercado agrícola de seus parceiros ricos. O único a tocar no assunto, assim mesmo tangencialmente, foi o ministro do Desenvolvimento, Clóvis Carvalho, que adotou tom protecionista. Para ele, o Brasil deve jogar na ofensiva, para derrubar as barreiras, mas também na defensiva, para que não tenha que ceder em outras áreas, como a dos produtos industriais, como ocorreu em outras negociações (Folha de São Paulo, 04/08/1999).

De maneira geral, o tom da cobertura dessas negociações comerciais na imprensa brasileira passa a impressão de que realmente seria possível que o governo conseguisse algum sucesso neste tipo de "ofensiva". A citação acima se parece com a narração de um jogo esportivo, que descreve posições "ofensivas" e "defensivas" do Estado brasileiro, voltado para os interesses do agronegócio.

Em 26 de Outubro de 1999, a Folha de São Paulo traz um artigo de Marcos Jank que expressa o mesmo tipo de avaliação sobre as negociações da chamada Rodada do Milênio na OMC, que ocorreria em novembro daquele ano em Seattle. Na época, Jank 
era professor da Escola Superior de Agricultura Luiz de Queiroz (ESALQ) e pesquisador do Programa de Estudos dos Negócios do Sistema Agroindustrial (PENSA). O teor do texto repete as reclamações corriqueiras dos defensores do agronegócio sobre os subsídios que os países da OCDE concedem à sua agricultura. $\mathrm{O}$ autor reconhece que as negociações dos acordos de "livre" comércio não alteraram este quadro: "Entre o início da Rodada Uruguai e o início da Rodada do Milênio houve uma deterioração nos níveis do protecionismo mundial. A OCDE estima que os subsídios totais ao produtor atingiram, em 98, US\$ 362 bilhões/ano, contra US\$ 320 bilhões no período 1986-1988.” Apesar de destacar estes números, Jank afirma que a solução para a economia brasileira seria continuar apostando nas negociações da OMC. Ele utiliza como argumento o suposto peso do agronegócio no PIB brasileiro:

O agronegócio responde por $32 \%$ do PIB (Produto Interno Bruto) brasileiro (cerca de US\$ 250 bilhões/ano), 38\% da pauta de exportações (US\$ 20 bilhões/ ano) e mais de $40 \%$ da população economicamente ativa. O Brasil enfrenta um preocupante desequilíbrio na balança de pagamentos. Para reverter esse quadro, é necessário exportar mais. A meta de US\$ 100 bilhões em exportações até 2003 (US\$ 44 bilhões no agronegócio) depende das negociações na OMC (Folha de São Paulo, 26/10/1999).

O artigo sugere que o governo brasileiro insista em pedir aos países "desenvolvidos" que eliminem seus subsídios para exportação, reduzam suas tarifas para importação e seus subsídios internos. Apesar de fantasiosa, essa expectativa se mantém no discurso dos porta-vozes do agronegócio e de sucessivos governos. Em pleno auge do período neoliberal, Jank reconhece que os países centrais aplicavam políticas exatamente opostas àquelas defendidas no Brasil:

As palavras de ordem da agricultura na maioria dos países desenvolvidos são preços de sustentação administrados pelos governos, restrições às importações, barreiras técnicas (sanitárias, de qualidade, e agora ambientais e sociais), formação de estoques públicos, ajudas diretas aos produtores, salvaguardas especiais, compras governamentais e comércio dominado por monopólios públicos e privados. Fechando o ciclo da proteção, os excedentes são exportados por meio de abundantes subsídios e créditos governamentais (Folha de São Paulo, 26/10/1999).

Após o "fracasso" das negociações da OMC em Seattle, um artigo de Clóvis Rossi intitulado "O muro agrícola e o Brasil" retrata a impossibilidade de se implantar este tipo de agenda comercial:

Se o ministro da Agricultura, Marcus Vinicius Pratini de Moraes, fosse o chefe da delegação brasileira na $3^{\text {a }}$ Conferência Ministerial da OMC (Organização Mundial do Comércio), ele chutaria o pau da barraca. 'Se não constar do documento final a eliminação dos subsídios à agricultura, é melhor que não haja uma nova rodada', dispara Pratini (Folha de São Paulo, 03/12/1999). 
A “ira” do ministro Pratini é explicada na matéria pelo fato de a União Europeia não aceitar eliminar os subsídios à sua agricultura, como já era esperado. Entretanto, o ministro, desapontado, diz: "Suspeito que o Brasil vai sair de Seattle sem obter o seu máximo objetivo, que era abrir o mercado agrícola dos países ricos para a sua própria e competitiva exportação". Rossi conclui o artigo com um tom crítico:

Não deixa de ser uma ironia que o país chegue às portas de um novo milênio dependendo de exportações de bens que foram os primeiros a serem comercializados no planeta, séculos ou milênios atrás. E ainda por cima encontra um muro de resistências que justificam a ira de seu ministro da Agricultura (Folha de São Paulo, 03/12/1999).

Um texto do próprio ministro Pratini de Moraes, publicado na Folha de São

Paulo em 5 de setembro de 1999, revela o pensamento que permeava o governo, baseado na expectativa de que ocorreria maior "integração" do comércio mundial. O artigo intitulado "O futuro da agricultura está no mercado" defende também o aumento da liberalização do capital financeiro:

Com o processo de globalização da economia e a crescente integração das nações em blocos econômicos, a sobrevivência de uma atividade como a agricultura torna imprescindível a busca da competitividade. Confiabilidade, sanidade e qualidade são precondições para conquistar novos mercados. Além disso, no anúncio do Plano Agrícola 1999/2000, o presidente da República determinou a adoção de providências para aperfeiçoar as condições de proteção de safra, por meio de operações nos mercados futuros. O que se está buscando é um mercado de maior liquidez, com maior número de participantes, inclusive permitindo aos investidores não-residentes no Brasil realizar aqui suas aplicações. Ao autorizar os investidores externos a operar nos mercados futuros agrícolas brasileiros, o Conselho Monetário Nacional (CMN) acabou com o tratamento diferenciado que impedia investidores estrangeiros de operar em nosso país, visto que os brasileiros já estavam autorizados a operar nas Bolsas estrangeiras (Folha de São Paulo em 5 de setembro de 1999).

Este artigo é emblemático por demonstrar o aprofundamento da política governamental de estímulo a medidas que permitissem maior dependência do agronegócio em relação ao capital financeiro, através da aposta nos mercados de futuro. A intenção do texto é defender a medida como fonte de "segurança" e "proteção de preços" para commodities agrícolas. Mas o que ocorreu com a introdução de novos mecanismos de especulação financeira foi o aumento da situação de instabilidade no mercado de commodities. Porém, o ministro Pratini de Moraes alegava que ocorreria justamente o contrário:

À exceção do café, o mercado de futuros agrícolas no Brasil é incipiente. O total de contratos negociados não atinge $1 \%$ da safra. Existem no Brasil contratos futuros para açúcar, algodão, café, milho, soja e boi gordo. Com a perspectiva 
de dinamização dos negócios, os produtores, as cooperativas, os comerciantes, as indústrias e os exportadores terão melhores condições para operar, dando liquidez ao mercado e maior segurança para a realização de contratos de médio prazo (Folha de São Paulo em 5 de setembro de 1999).

Em outro trecho do artigo, a retórica de Pratini repete o conhecido jargão de que "O Brasil é um dos países com maior potencial de crescimento da produção agrícola do mundo. Somos a última fronteira agrícola do planeta”. Este discurso ufanista serve como preâmbulo para a descrição da crise no agronegócio, expressa na seguinte preocupação: "A agricultura brasileira vive um momento difícil: a renda caiu, inúmeros agricultores não têm condições de honrar os seus compromissos ou precisam de uma prorrogação de dívida". Como saída para a crise, o ministro propõe "derrubar fronteiras e fortalecer toda a cadeia de produção, o que nos permitirá exportar nossos produtos com mais agressividade". O ministro admite ainda que, para conseguir a esperada "renda", o agronegócio deveria recorrer aos "mercados futuros". A impossibilidade de rentabilidade do agronegócio é mencionada também na seguinte citação:

Todavia esse potencial só será aproveitado em sua plenitude se houver mercado e perspectivas de rentabilidade para o setor. (...) Nessas condições, o país terá na agricultura um seguro alicerce para atender às expectativas da sociedade, quanto à geração de mais renda e emprego. Porém não se faz agricultura sem renda (Folha de São Paulo em 5 de setembro de 1999).

Em 28 de dezembro de 1999 a Folha de São Paulo publica uma matéria com dados do Instituto de Pesquisa Econômica Aplicada (IPEA) afirmando que o maior saldo comercial da agricultura brasileira viria de regiões com "produções que não exigem a compra de muitos insumos importados ou tecnologia estrangeira para funcionar". A reportagem conclui que "Esse é o único setor em que o país tem superávits, de cerca de US\$ 10 bilhões por ano, pois tem vantagens naturais”. Estas informações revelam que o suposto superávit (que, como vimos anteriormente, é menor do que o montante de subsídios estatais para o setor) só se materializa a partir da crescente apropriação de forças produtivas baseadas em recursos naturais como água e fertilidade do solo. Tal constatação desfaz a imagem de eficiência da grande exploração agrícola baseada em insumos industriais. A necessidade de expansão territorial pode ser analisada como forma de minimizar as contradições da agricultura capitalista através do monopólio sobre forças produtivas que não são fruto do trabalho humano. O caráter extensivo do agronegócio se mantém através da aliança com a oligarquia latifundista. 
Em sua análise crítica sobre o agronegócio na atualidade, Delgado (2012) explica que as chamadas vantagens naturais da economia brasileira se referem à apropriação da renda da terra, a partir da manutenção de um contexto, segundo o qual:

Nas condições atuais, as razões do sucesso conjuntural dos vários "setores" que crescem á frente dos demais - agricultura, mineração, hidroeletricidade e exploração de petróleo, decorrem de um conjunto de condições econômicas externas que ressaltam as vantagens comparativas naturais e a apropriação da renda fundiária como principais motores de acumulação de capital no sistema econômico brasileiro (DELGADO, 2012, p. 2-4).

\section{Neoliberalismo e Desenvolvimentismo}

O discurso sobre a suposta vocação agrícola do Brasil está relacionado com a noção de desenvolvimento como se representasse um processo linear e progressivo, rumo a um patamar ideal. Este tipo de pensamento pode ser identificado tanto entre os ideólogos do neoliberalismo quanto entre correntes consideradas desenvolvimentistas. Por exemplo, o artigo de Benjamin Steinbruch, que era presidente dos conselhos de administração da Companhia Siderúrgica Nacional e da Companhia Vale do Rio Doce, anuncia que teria surgido "A nova agricultura" no momento das "comemorações dos 499 anos do descobrimento". O texto lembra a carta de Pero Vaz de Caminha, que é chamada de "certidão de nascimento" do Brasil e, referindo-se a terra, diz que seria "tão boa e generosa que em se plantando dar-se-á nela tudo". Para Steinbruch, tal "profecia" não teria se realizado pelo seguinte motivo:

(...) falta a sociedade e as autoridades entenderem a importância da prioridade agrícola nesta hora difícil da nossa economia (...) é preciso agir logo, com força e determinação, para inserir o Brasil, de uma vez, no mundo da nova agricultura. Na nossa terra não se dará tudo só por causa da profecia de Pero Vaz (Folha de São Paulo, 27/04/1999).

Depois de fazer essa recomendação, Steinbruch adverte para o baixo nível de produtividade da agricultura brasileira, com base em dados que mostram que a safra de 98/99 fora menor do que a do ano anterior. Entretanto, o autor reafirma sua aposta no "futuro" de um de um "país essencialmente agrícola". O texto alega que "mesmo antes da crise da economia asiática, do vendaval das Bolsas mundiais e do choque da desvalorização do real, a agricultura (e os agronegócios) já aparecia como grande solução para recolocar o Brasil no rumo do desenvolvimento" (Folha de São Paulo, 27/04/1999). 
Para chegar a este tipo de "desenvolvimento", Steinbruch recomenda maiores investimentos em "atualização tecnológica", sob o seguinte argumento: "O agronegócio está se transformando a grande velocidade, em todo o mundo". Como proposta para aumentar a produtividade agrícola no Brasil, o autor defende investimentos na "indústria e no comércio de insumos". De acordo com sua visão, "Essa revolução começa a ocorrer em uma hora em que o produtor brasileiro descobre que a terra, o solo, que há 30 ou 40 anos representava $60 \%$ a $80 \%$ do investimento agrícola, hoje não passa de 5\% a 10\% do custo nas maiores culturas" (Folha de São Paulo, 27/04/1999). O processo chamado por Steinbruch de "revolução" caracteriza a tendência de crise que observamos nos capítulos anteriores, quando analisamos a chamada industrialização da agricultura como fator que estimulou o desequilíbrio na composição orgânica do capital. Steinbruch reconhece a elevação do custo de insumos industriais na produção agrícola, mas utiliza estes dados para defender o aumento do apoio estatal para o agronegócio:

O presidente Fernando Henrique bem que poderia alçar a agricultura à condição de primeira meta no seu plano de retomada do desenvolvimento. Para isso, o governo precisará fazer a sua parte, completando a infra-estrutura necessária a nos transformar em uma grande potência agrícola. (...) Esse programa não terá apenas o apoio de todos os que estão presentes na produção agrícola e nos agronegócios. Ele terá a parceria de todos os brasileiros que acreditam na terra. Suas respostas rápidas e eficazes vão mexer com todo o Brasil. E é um industrial que lembra, neste texto, que não podemos adiá-lo mais (Folha de São Paulo, 27/04/1999).

O texto acima procura difundir uma imagem nacionalista do agronegócio ao sugerir que o apelo para que governo conceda maior apoio e infraestrutura para a agricultura extensiva viria de "todos os brasileiros". Uma reportagem intitulada "Pacto visa consumo interno", publicada pela Folha de São Paulo em 28 de setembro de 1999, revela que a crise nos monocultivos para exportação gerou propostas em defesa de políticas agrícolas para o mercado local, porém sem alteração na prioridade da concessão de subsídios estatais para a grande exploração. A matéria se refere a uma campanha para incentivar o consumo interno de suco de laranja, articulada por "representantes de citricultores, indústrias de suco, trabalhadores rurais, fabricantes de agrotóxicos e governo do Estado de São Paulo no Pacto pelo Emprego no Agronegócio de Citros". A reportagem mostra que o mesmo tipo de "pacto" foi negociado no setor sucroalcooleiro:

Assim como foi feito no segmento da cana-de-açúcar no mês passado, agora será a vez da laranja, segunda cultura mais importante no Estado de São Paulo. No caso da cana, governo do Estado, governo federal, montadoras de veículos, 
produtores, distribuidores e trabalhadores do setor sucroalcooleiro assinaram um pacto para tentar conter o desemprego nos canaviais paulistas (Folha de São Paulo, 28/09/1999).

A articulação de lobbies que incluem diferentes elos da cadeia do agronegócio tem como propósito demandar políticas adicionais de subsídios. Naquele contexto, a resposta estatal foi aumentar a concessão de isenção fiscal:

O governo do Estado se comprometeu, por exemplo, a dar isenção de $100 \%$ no IPVA (Imposto sobre Propriedade de Veículos Automotores) de 99 e 2000 para quem comprar carro a álcool até 31 de dezembro deste ano. (...) Na laranja, entre as medidas analisadas, consta a isenção de ICMS (Imposto sobre Circulação de Mercadorias e Serviços) para o suco e para a fruta (Folha de São Paulo, 28/09/1999).

Outra matéria que relata a permanência da crise no agronegócio foi publicada no dia 23 de fevereiro de 1999. Com o título, "Cana perde produtividade na região CentroSul nesta safra", a reportagem afirma que "a região Centro-Sul deverá ter um rendimento menor na safra atual devido à queda de produtividade nas lavouras". Dados divulgados pela União da Agroindústria Canavieira do Estado de São Paulo (UNICA) mostram que a queda de produtividade gerou uma redução de $2 \%$ no "rendimento industrial" do setor. Uma das causas identificadas na reportagem seria a "redução do uso de insumos, como adubos e herbicidas, usados no preparo da lavoura desta safra. A explicação para a diminuição no uso de insumos é a perda de renda do setor sucroalcooleiro, que foi $30 \%$ menor na colheita passada em relação à safra 97/98" (Folha de São Paulo, 23/02/1999). O texto demonstra, por um lado, a dependência de produtos químicos na produção agrícola e, por outro, como o custo destes insumos acaba por gerar a diminuição da renda e da produtividade.

Em 20 de janeiro de 1999, um artigo de João Carlos de Souza Meirelles, que usa as credenciais "pecuarista e colonizador, é secretário de Agricultura e Abastecimento do Estado de São Paulo", traz dados adicionais sobre a crise na agricultura extensiva com ênfase na diminuição dos postos de trabalho. Como analisamos nos capítulos anteriores, o processo de industrialização da agricultura gera um movimento de reprodução crítica do capital que reduz sua capacidade de explorar trabalho, ou seja, de valorização. Seguem os números daquele período com base no Censo do IBGE:

Em dez anos, São Paulo eliminou um terço dos empregos no campo, segundo revela o Censo Agropecuário divulgado no final de dezembro pelo Instituto Brasileiro de Geografia e Estatística (IBGE). Em todo o Brasil, foram extintos mais de 5 milhões de vagas na agricultura, caindo o contingente desses 
trabalhadores de 23,3 milhões em 1985 para 17,9 milhões em 1995. Nesses três últimos anos, a situação, se mudou, foi para pior (Folha de São Paulo, 20/01/1999).

Meirelles explica o desemprego no campo como se resultasse "da globalização da economia" e lamenta que haja menos possibilidade de se explorar trabalho, considerando tal situação como "inaceitável o desperdício social da inatividade". O autor ressalta supostas vantagens das chamadas cadeias produtivas, que classifica como "fronteira para a mais rápida e eficiente expansão econômica. (...) Essa deve ser, portanto, a via pela qual se fará a inserção da agropecuária no mercado globalizado, observando-se o conceito de agronegócio compreendido nas cadeias produtivas". O artigo exemplifica um tipo de discurso comum entre os porta-vozes do agronegócio, que justificam problemas sociais a partir de um viés determinista. O texto cita o economista John Kenneth Galbraith que "prevê o inexorável avanço da globalização". Portanto, Meirelles considera o processo histórico a partir de uma perspectiva de inevitabilidade e linearidade, que seria movido pelo "avanço da globalização". Sem aparente conexão com os dados apresentados pelo próprio autor, a conclusão do artigo apresenta um tom ufanista que defende:

(...) o agronegócio como a alternativa mais viável para o desenvolvimento econômico, capaz de resolver o problema da ocupação com a exploração das vocações agronômicas e zootécnicas próprias de cada região, de forma que leve à máxima viabilização econômica, pela integração das cadeias produtivas. Essas cadeias, agregando o máximo de valor ao produto, dinamizam a atividade local integrada regionalmente, o que amplia as fronteiras do desenvolvimento dentro do necessário crescimento sustentado (Folha de São Paulo, 20/01/1999).

Como vimos anteriormente, as definições de cadeia produtiva e agronegócio foram forjadas no meio acadêmico e difundidas através dos meios de comunicação, servindo de aparato ideológico para apoiar políticas de Estado que historicamente favoreceram esse setor. Uma notícia publicada no caderno Agrofolha, em 23 de fevereiro de 1999, exemplifica como estas definições passaram a integrar os currículos das universidades brasileiras e, com isso, criar a impressão de que o agronegócio seria um campo promissor de geração de empregos:

Com o objetivo de atender aos jovens profissionais que querem se atualizar com o sistema agroindustrial brasileiro, o $7^{\circ}$ Curso Pensa de Agribusiness 1999 está ampliando a sua programação. Organizado pelo Pensa (Programa de Estudos dos Negócios do Sistema Agroindustrial) Fundação Instituto de Administração da FEA/USP, de São Paulo, o curso irá acontecer de abril a junho próximos (...). Gerenciamento de sistemas agroindustriais, análise de sistemas específicos, marketing e comportamento do consumidor estão entre os temas que serão 
abordados pelo cronograma. O professor Samuel Ribeiro Giordano, outro organizador do evento, diz que o curso atende a uma ampla gama de profissionais que atuam no agribusiness em todas as suas fases, desde os insumos, a produção rural, a agroindústria, as cooperativas, as redes de distribuição chegando até aos consumidores (Folha de São Paulo, 23/02/1999).

Além de fazer parte do vocabulário oficial das universidades, as concepções de agronegócio e cadeia produtiva foram incluídas nas instituições de governo, como mostra a seguinte reportagem:

$\mathrm{Na}$ próxima semana, começam as articulações para formar o Conselho do Agronegócio, proposta do Fórum Nacional de Agricultura feita ao governo federal. A idéia é aumentar as exportações. (...) O secretário paulista de Agricultura, João Carlos de Souza Meirelles, esteve com o ministro Celso Lafer e pediu esforço concentrado na adequação das leis brasileiras às normas do mercado internacional e maior ênfase às cadeias de produção (Folha de São Paulo, 05/02/1999).

As matérias citadas acima demonstram como a difusão da imagem de eficiência do agronegócio serviu para impulsionar a criação de estruturas estatais, nos campos econômicos, políticos, acadêmicos e jurídicos, em apoio às chamadas cadeias de produção formadas por capitais agrícolas, industriais e financeiros, em simbiose com a oligarquia latifundista. O discurso ufanista que relaciona o agronegócio à ideia de desenvolvimento se mantém até a atualidade.

Como vimos através de nossa pesquisa em jornais de grande circulação, que promovem tal discurso através de determinados porta-vozes ou formadores de opinião, o sentido contraditório e crítico do processo de industrialização da agricultura é omitido. Na década de 2000, observamos a relação entre a crise financeira internacional e um novo impulso na acumulação de capital com base na renda da terra, que aparece como expansão de monocultivos e de outros setores primários da economia no Brasil, como energia e mineração. Delgado (2012) analisa este cenário a partir do seguinte contexto:

(...) processo de reinserção do Brasil no comércio mundial de "commodities", conjunturalmente superar os limites de constrangimento externo a que estivera submetido na fase ultra-liberal do Governo FHC I. Tais limites são repostos pelo recrudescimento do déficit em Conta Corrente já a partir de 2008 e se mantêm até o presente. Essa inserção primário-exportadora - da agricultura e da mineração, empurra o sistema econômico para um duplo processo superexploração de recursos naturais e de trabalho humano, sob pressão de oferecer relativo equilíbrio às transações externas de mercadorias e serviços. Certo período de 'boom' dos preços das "commodities" ao longo dos anos 2000 cria a ilusão de solução estrutural ao desequilíbrio externa, já desmanchada pelas evidências factuais. Mas o modelo segue seu curso externo com o avanço 
acentuado das exportações primárias, ao que corresponde internamente uma também notória estratégia privada e estatal de apropriação da renda fundiária das terras rurais, das jazidas minerais e dos campos petroleiros (DELGADO, 2011, p. 2-4).

Para o autor é importante esclarecer que a opção por um modelo econômico que prioriza a exportação de "commodities agrícolas e minerais (...) não tem condições de gerar equilíbrio externo na Conta Corrente, mas ao contrário aprofunda o desequilíbrio externo da economia brasileira em médio prazo" (DELGADO, 2012, cap. 6). O autor demonstra os limites da estratégia agroexportadora a partir de dados da última década e afirma que:

(...) é absolutamente inviável como solução estrutural ao desequilíbrio externo, até mesmo porque a persistência do 'déficit' no quadriênio 2008-2011evidencia um custo de remuneração ao capital estrangeiro que não pode ser compensado por saldos comerciais, gerados pelas 'vantagens corporativas' das exportações primárias (DELGADO, 2012, cap. 5).

Delgado investiga o processo atual que chama de "novo pacto da economia política do agronegócio", como uma fase posterior que mantém elementos econômicos semelhantes aos da conjuntura que propiciou a industrialização da agricultura no Brasil entre as décadas de 1960 e 1980, mas que acabou por gerar a crise da dívida:

O que fica evidente nos anos 2000 é o relançamento de alguns complexos agroindustriais, da grande propriedade fundiária e de determinadas políticas de Estado, tornando viável um peculiar projeto de acumulação de capital para o qual é essencial a captura da renda de terra juntamente com a lucratividade do conjunto dos capitais consorciadas no agronegócio (DELGADO, 2012, cap. 5).

Recentemente, empresas do agronegócio, principalmente ligadas à Associação Brasileira do Agronegócio (Abag), buscaram se dissociar da ideia de negócio e valorizar o a imagem de agro. Para isso, patrocinaram uma campanha publicitária com o slogan Sou Agro. É possível interpretar que tal campanha tenha sido motivada pela possibilidade de desgaste deste modelo agrícola para a opinião pública, que é estimulada pela ação de entidades e movimentos sociais no sentido de revelar a crise estrutural do setor. Alguns aspectos tornaram essa crise mais aparente, entre eles o aumento do preço dos alimentos, as diversas denúncias de violência no campo e destruição ambiental, além de estudos sobre os impactos dos agrotóxicos, entre outros.

Esta nova roupagem do agronegócio é analisada por Regina Bruno a partir da necessidade que a classe patronal teria de dar continuidade à disputa por hegemonia na sociedade. Ela explica que, "Se na década de 1960 as elites rurais defendiam um 'Brasil 
vocação agrícola', hoje os porta-vozes do agronegócio apregoam que 'o planeta é agro"” (BRUNO, 2012, p. 5). Bruno vê continuidade entre a imagem criada pela propaganda Sou Agro e a visão difundida historicamente, que apresenta o Brasil como "celeiro do mundo":

Na primeira metade da década de 1980, dois aspectos eram muito caros aos representantes dos grandes proprietários de terra e empresários agroindustriais: o fortalecimento de uma assessoria jurídica e a renovação da assessoria responsável por propaganda e marketing. Hoje, juntamente com o processo de construção da hegemonia do agronegócio (...), o recurso à mídia e ao marketing na construção da imagem assume um papel cada vez mais expressivo (BRUNO, 2012, p. 18).

A aposta das associações do agronegócio em campanhas publicitárias tem como objetivo continuar a projetar a imagem de eficiência e progresso, em um contexto de crise e vulnerabilidade econômica ${ }^{109}$. O slogan Sou Agro serve também para associar o agronegócio à ideia de que este segmento serviria a toda sociedade. Além de procurar dissimular a persistência da concentração fundiária no Brasil, a campanha publicitária promovida pelas empresas do agronegócio repete mensagens conhecidas. Ray Goldberg, por exemplo, continua a ser citado como referência teórica.

Em artigo publicado no jornal $O$ Estado de São Paulo em 26 de setembro de 2012, Decio Zylbersztajn lembra o estudo Agribusiness Coordination (1968), no qual Goldberg promove "a necessidade de aprimorar os mecanismos de coordenação agroindustrial; e o crescente poder da indústria e da distribuição de alimentos”. Segundo Zylbersztajn, este tipo de mecanismo serviria para mostrar que, "Do valor total gerado nos sistemas produtivos de base agrícola, uma parcela crescente caberia ao processamento e distribuição, prenunciando que as margens da fase agrícola seriam mais apertadas”. Esta afirmação mostra que Zylbersztajn reconhece, de alguma forma, a crise de valorização do agronegócio. Porém, inspirado em Goldberg, ele propõe "cooperação" entre os agentes do setor e afirma que:

Os preços não são suficientes para a coordenação dos sistemas agroindustriais modernos. Mecanismos contratuais são adotados refletindo estratégias conjuntas de geração e compartilhamento de valor. Elaborar estratégias conjuntas não significa que os conflitos são eliminados, só que são explicitados e gerenciados.

\footnotetext{
${ }^{109}$ Dados disponíveis em MENDONÇA; Maria L.; PITTA; Fábio T.; XAVIER, Carlos V. A Agroindústria Canavieira e a Crise Econômica Mundial. Editora Outras Expressões, São Paulo, 2012. http://www.social.org.br/relatorioagrocombustiveis2012.pdf.
} 
A ideia central é cooperar para gerar valor com base em regras de compartilhamento de resultados e riscos (Estado de São Paulo, 26/09/2012 $2^{110}$ ).

Nos vários períodos que pesquisamos o pensamento dos ideólogos do agronegócio, encontramos referências à situação de crise deste modelo agrícola, desde nossa análise sobre a criação do conceito a partir do livro A Concept of agribusiness de John Davis e Ray Goldberg, publicado em 1957, até esta recente sistematização a partir da construção do termo na imprensa brasileira.

${ }^{110}$ O Estado de S. Paulo, 26/09/2012.

http://www.noticiasagricolas.com.br/noticias/agronegocio/111356-harmonizacao-agroindustrial-por-decio-zylbersztajn.html. Consulta em 12/11/2012. 


\section{Consideracões finais}

Os diversos elementos que compuseram esta tese nos levaram a concluir que a chamada industrialização da agricultura ocorre em um contexto crítico, que entendemos como parte da crise do modo capitalista de produção, mas que aparece como acumulação, ou de maneira idealizada nas denominações fetichistas de crescimento e desenvolvimento econômico. Neste sentido, o produto do agronegócio é a própria dívida, que se expressa na busca por valorização de capitais financeiros e industriais a partir da renda da terra.

A pesquisa sobre a representação do agronegócio na imprensa brasileira sugere que a ideia de desenvolvimento, crescimento e avanço tecnológico, tendo como significado um movimento progressivo e linear, marca tanto o pensamento das correntes desenvolvimentistas quanto das neoliberais. Ambas defendem apoio estatal para a agricultura extensiva, baseada nas chamadas cadeias produtivas, ou seja, no sistema do agronegócio. É possível observar que os elementos que integram os períodos de expansão do setor coincidem com aqueles identificados como determinantes para gerar crise. Portanto, concluímos que tais fatores de estímulo à acumulação se convertem em limites na realização do produto do agronegócio que seria a valorização de capitais.

A sistematização das ideias difundidas pelos porta-vozes do agronegócio nos órgãos de imprensa pesquisados nos leva a perceber que sua interpretação de progresso tecnológico está associada ao pensamento desenvolvimentista que prevalece na década de 1960 e que, posteriormente, se transmuta na ideologia neoliberal. Em relação à defesa do modelo agrícola extensivo e industrializado, ambas correntes de pensamento coincidem ao defender o apoio estatal para o setor inicialmente chamado de complexo agroindustrial e que, mais recentemente, foi denominado de agronegócio.

Identificamos ainda que tanto no período considerado desenvolvimentista, quanto naquele chamado de neoliberal, prevalece a defesa de uma política estatal de apoio ao modelo agroexportador, com base no argumento de que seria a forma possível de se garantir equilíbrio na balança comercial brasileira. Entretanto, verificamos que nos diversos períodos pesquisados, os subsídios estatais para o agronegócio superaram o saldo deste setor na balança comercial agrícola. Em 1980, por exemplo, o governo concedeu perdão de uma dívida de US\$13 bilhões de dólares ao agronegócio, montante que representava o dobro de seu saldo na balança comercial. 
Historicamente, a agricultura brasileira esteve voltada principalmente para o mercado externo. Apesar da prevalência do modelo agroexportador, até os anos 1970 percebe-se que o Estado brasileiro exercia um papel significativo sobre estoques de alimentos, estabelecendo cotas para exportação, além de políticas comerciais de controle de importações agrícolas. Durante aquele período, a política de apoio estatal para a produção de alimentos buscava atender, em certa medida, o mercado interno. Esta política tinha como função principal subsidiar a reprodução da força de trabalho para a indústria, com o propósito de manter salários em um patamar mais baixo e, desta forma, garantir maior extração de mais-valia. No início dos anos 1980, o debate sobre a estrutura fundiária brasileira volta a permear o cenário político, com grandes mobilizações de luta pela terra e o fortalecimento de sindicatos rurais e organizações populares no campo, como o Movimento Sem Terra (MST).

A conjuntura internacional pós-guerra, nos anos 1950, marcou um período de superacumulação de capital e, posteriormente, o contexto da Guerra Fria se caracterizou pela intensificação da exportação de capitais dos países centrais para a periferia do capitalismo, o que acabou por gerar a chamada crise da dívida na América Latina. $\mathrm{O}$ debate regional naquele momento destacava a necessidade de se estabelecer acordos comerciais de integração entre países latino-americanos. Em consequência deste cenário, acirram-se disputas políticas contra a declaração de moratória de diversos países que buscavam negociar o pagamento da dívida externa.

È neste contexto que a ideologia neoliberal começa a ser difundida mais amplamente, sob o pretexto de enxugar o Estado com medidas de ajuste estrutural, propagandeadas como solução para saldar a dívida externa na periferia do capitalismo. Tais políticas ganham força principalmente a partir do governo de Margareth Thatcher na Inglaterra e com a eleição de Ronald Reagan nos Estados Unidos. Estes países inauguram o discurso em favor da desregulamentação comercial e condenam o protecionismo e intervencionismo do Estado brasileiro na agricultura.

O fim da ditadura militar no Brasil coincide com a difusão de um discurso em defesa de políticas de austeridade fiscal e livre comércio. As reformas neoliberais eram apresentadas como solução para a crise da dívida externa. Os anos 1990 foram marcados por políticas de privatização de empresas estatais, inclusive com a desregulamentação dos estoques de alimentos. As demandas sociais por reforma agrária 
não se concretizam e, portanto, aumenta o processo de êxodo rural e o agravando da chamada metropolização da pobreza.

Nesta nova ordem econômica a elevação da concentração de capitais privados é caracterizada pelas chamadas parcerias produtivas ou joint ventures, que intensificam a formação de monopólios em diferentes setores da economia, inclusive no agronegócio. Muitos destes negócios são financiados com recursos estatais, principalmente do Banco Nacional de Desenvolvimento Econômico e Social (BNDES). Nossa pesquisa verificou que os mesmos ideólogos que pregavam o enxugamento do Estado saudavam a formação de monopólios privados, que chamavam de alianças estratégicas.

A constituição de monopólios privados no controle da produção e comercialização agrícolas ocorre simultaneamente a um processo de crescente predominância do capital financeiro na agricultura, com o fortalecimento dos mercados de futuro e de outros mecanismos financeiros utilizados pelo agronegócio, além da continuidade de concessão de créditos especiais para o setor. Outra característica deste momento foi o aumento da especulação com commodities agrícolas, gerando instabilidade nos preços dos alimentos. Esta crise se agrava em função da desregulamentação comercial, que facilitou mecanismos de dumping.

Entretanto, a imagem da grande exploração agrícola continuamente projetada nos meios acadêmicos, políticos e de comunicação, apresenta este setor como gerador de riqueza e desenvolvimento. Um dos assuntos mais frequentes diz respeito ao suposto peso do agronegócio no Produto Interno Bruto (PIB) brasileiro, calculado sempre entre $30 \%$ e $40 \%$. A fórmula que permite inflar a percentagem do agronegócio no PIB está baseada na formação das chamadas cadeias produtivas, com o objetivo de justificar a inclusão de atividades agroquímicas, industriais e comerciais aos cálculos econômicos da agricultura. A partir dessa lógica, o setor é visto como gerador de divisas e equilíbrio econômico.

Além da imagem de âncora comercial, os créditos subsidiados e as constantes rolagens de dívidas do agronegócio são anunciados como indispensáveis no sentido de se alcançar avanços tecnológicos na produção agrícola. Assim, as políticas de livre comércio, que visam consolidar vantagens comerciais para o setor agrícola baseado no monocultivo para exportação, são articuladas com uma série de medidas de lobby, acesso a mercados e infraestrutura. Um exemplo foi a aprovação da chamada Lei Kandir 
que a partir de 1996 possibilitou novas formas de incentivos fiscais para a exportação agrícola.

Apesar de seu acesso a diversos tipos de incentivos fiscais, verificamos que a situação de endividamento permaneceu para o agronegócio. Da mesma forma como ocorreu nos anos 1980, em 1999 o governo concedeu perdão a uma dívida de US\$18 bilhões de dólares ao setor, quando o superávit comercial anunciado era de US\$10 bilhões de dólares. Apesar do conhecimento sobre estes números, tanto os ideólogos de correntes desenvolvimentistas quanto os neoliberais seguem defendendo forte apoio estatal para o agronegócio. Ambos insistem em condenar o protecionismo dos países ricos e a defender uma política de maior acesso a mercados ou abertura comercial para commodities brasileiras. A política externa governamental em favor do agronegócio é projetada sob a justificativa de que seria necessária para assegurar estabilização econômica.

A construção do conceito de agronegócio, inicialmente forjada nas universidades dos Estados Unidos como agribusiness, foi importada através de meios acadêmicos e políticos no Brasil e serviu de base ideológica para explicar a continuidade do apoio estatal para o latifúndio e para a intensificação do uso de insumos industriais na agricultura. $\mathrm{Na}$ atualidade, o conceito de agronegócio continua a ser difundido nos meios de comunicação, associado à imagem de eficiência e desenvolvimento. O jornal Valor Econômico, por exemplo, que representa hoje um dos periódicos econômicos de maior circulação no país, mantém uma seção dedicada a agronegócios.

O discurso atual dos porta-vozes do setor permanece focado no lobby em favor de subsídios e outros mecanismos governamentais para a expansão de monocultivos para exportação, inclusive com recentes pressões políticas que resultaram no desmonte do Código Florestal. As mudanças na legislação ambiental tiveram como objetivo permitir maior avanço do agronegócio, principalmente em áreas com acesso a infraestrutura, vastas bacias hidrográficas e biodiversidade, que coincidem com elementos que analisamos nos capítulos anteriores sobre a renda da terra.

A difusão da ideia de crescimento econômico, que permanece na atualidade, serve pare esconder a dimensão que a crise mundial toma no Brasil, que se expressa na concentração de capitais no campo e no movimento de capitais financeiros que migram para o setor de commodities. O resultado é a geração de uma bolha especulativa, que 
tem causado forte aumento no preço da terra, além de estimular fusões entre a oligarquia latifundista e grandes empresas nacionais e multinacionais. A lógica do agronegócio está baseada na superexploração do trabalho e da renda da terra. Portanto, comunidades camponesas, indígenas e quilombolas sofrem constante repressão. Somente a transformação do modo capitalista de produção seria capaz de superar as crises simultâneas no âmbito econômico, social e ambiental. 


\section{Bibliografia}

ABRAMOVAY, R. De Camponeses a Agricultores: Paradigmas do Capitalismo Agrário em Questão, Editora UNICAMP, Campinas, 1992.

ADORNO, Theodor. Sobre Sujeito e Objeto. 1969. Disponível em: http://adorno.planetaclix.pt/tadorno2.htm. Consulta em 10/08/2010.

ALFREDO, Anselmo. Modernização e Reprodução Crítica. Agroindústria do Leite e Contradições do Processo de Acumulação. Em Geousp. Espaço e Tempo. Revista de Pós-Graduação, DG-FFLCH-USP, n. 24, 2008, p. 63-108.

. Negatividade e a Crítica à Crítica Crítica: Sobre Espaço, Tempo e Modernização. Em Cidades, Grupo de Estudos Urbanos (GEU), vol. 6, n. 10, julho a dezembro de 2009. p. 381-415.

ALTIERI, Miguel A. Ecological Impacts of Industrial agriculture and the Possibilities for Truly Sustainable Farming. In Hungry for Profit: The Agribusiness Threat to Farmers, Food, and the Environment. Monthly Review Press, New York, 2000.

AMIN, Samir. O capitalismo e a renda fundiária. In A Questão Agrária e o Capitalismo, Paz e Terra, Rio de Janeiro,1977.

ANDRADE, Manuel Correia de. A Terra e o Homem no Nordeste, Cortez Editora, São Paulo, $7^{\mathrm{a}}$ edição, 2005.

AUSTIN, James E. Agribusiness in Latin America, Praeger, New York, 1974.

BAGDIKIAN, Ben H. The Media Monopoly, 3rd ed., Beacon Press, Boston, 1990.

BOULDING, Kenneth E. Principles of Economic Policy, Englewood Cliffs, New Jersey, 1958. Economic Analysis, Vol. II, Harper \& Row, New York, 1966. The meaning of the Twentieth Century: The Great Transition,

Harper \& Row, New York, 1964.

BRUNO, Regina. Movimento Sou Agro: marketing, habitus e estratégias de poder do agronegócio. Artigo apresentado no $36^{\circ}$ Encontro da ANPOCS, Fortaleza, 2012.

; Carneiro, Olavo; Sevá, Janaina. Pesquisa sobre Representação

Patronal no Campo. Universidade Federal Rural do Rio de Janeiro, 2008.

BURBACH, Roger; FLYNN, Patricia. Agribusiness in the Americas, Monthly Review Press, 1980, New York.

CASTRO, Antônio Maria Gomes; LIMA, Suzana Maria Valle e CRISTO, Carlos Manuel Pedroso Neves. Cadeia Produtiva: Marco Conceitual para Apoiar a Prospecção Tecnológica (2002).

http://www.pee.mdic.gov.br/portalmdic/arquivos/dwnl_1197031881.pdf (consulta em 28/07/11). 
CARVALHO-FILHO, J.J. e CASTELLO, A.M. A Ação do Estado e as Possibilidades da Pequena Produção. Análise Econômica, Ano 8, nº 13, Março/1990, Porto Alegre, UFRGS.

CHAYANOV, Alexander V. La Organización de La Unidad Económica Campesina. Ediciones Nueva Visón SAIC, Buenos Aires, 1974.

CHESNAIS, François. A Finança Mundializada, Boitempo Editorial, São Paulo, 2005.

CHOMSKY, Noam. Necessary Illusions: thought control in democratic societies, South End Press, Boston, 1989.

COCHRANE, Willard W. The development of American Agriculture: A Historical Analysis, University of Minnesota Press, Minneapolis, 1993.

COUTINHO, Carlos N. O Estruturalismo e a Miséria da Razão. Expressão Popular, São Paulo, 2010.

CRAMER, Gail L; JENSEN, Clarence W ; SOUTHGATES, Douglas DeWitt. Agricultural Economics and Agribusiness, John Wiley, New York, 2001.

DAVIS, John H., GOLDBERG, Ray A. A Concept of agribusiness. Harvard University Graduate School of Business Administration, Boston, 1957.

DAVIS, John Herbert ; HINSHAW, Kenneth. Farmer in a Business Suit. Simon and Schuster, New York, 1957.

DEBORD, Guy. A Sociedade do Espetáculo. Contraponto, Rio de Janeiro, 1997.

DELGADO, Guilherme C. Capital Financeiro e Agricultura no Brasil: 1965-1985. Campinas, Editora da UNICAMP/Ícone Editora, 1985.

Do Capital Financeiro na Agricultura à Economia do Agronegócio: Mudanças Cíclicas em Meio Século (1965-2012), (Mimeo do autor) Editora da UFRGS, 2012.

ENGELS, Friedrich. Do Socialismo Utópico ao Socialismo Científico. Centauro Editora, São Paulo, 2005.

ETC Group. Who will feed us? Questions for the Food and Climate Crises. Ottawa, Canadá, Novembro, 2009.

http://www.etcgroup.org/upload/publication/pdf_file/ETC_Who_Will_Feed_Us.pdf (consulta em 25/11/2010).

FAVERO, Celso Antonio. O Mercosul e a reestruturação da agricultura: As "filières" de cereais e a exclusão social. Em Cadernos de Ciência \& Tecnologia, Brasília, v.13, n.3, p.279-302, 1996.

FERNANDES, Bernardo M; MARQUES, Marta I. M.; SUZUKI, Julio C (org.). Geografia Agrária: Teoria e Poder. Expressão Popular. São Paulo, 2007. 
Folha de São Paulo, edições de 2 de janeiro de 1994, 16 de janeiro de 1994, 29 de março de 1994, 20 de abril de 1994, 1 de maio de 1994, 2 de julho de 1995, 1 de julho de 1995, 9 de outubro de 1995, 31 de outubro de 1995, 20 de julho de 1996, 2 de setembro de 1996, 29 de janeiro de 1997, 1 de outubro de 1997, 17 de janeiro de 1998, 31 de março de 1998, 25 de agosto de 1998, 15 de setembro de 1998, 2 de outubro de 1998, 13 de outubro de 1998, 15 de dezembro de 1998, 20 de janeiro de 1999, 5 de fevereiro de 1999, 23 de fevereiro de 1999, 27 de abril de 1999, 11 de junho de 1999, 15 de junho de 1999, 4 de agosto de 1999, 5 de setembro de 1999, 28 de setembro de 1999, 26 de outubro de 1999, 3 de dezembro de 1999, 28 de dezembro de 1999, 29 de dezembro de 1999.

FIGUEIRA, Ricardo Resende - Pisando Fora da Própria Sombra: A escravidão por dívida no Brasil contemporâneo, Ed. Civilização Brasileira, Rio de Janeiro, 2004.

Gazeta Mercantil, edições de 21 de outubro de 1962, 23 de outubro de 1962, 10 setembro de 1975, 16 de agosto de 1977, 30 de junho de 1979, 5 de julho de 1979, 30 março de 1979, 30 de junho de 1979, 1 de maio de 1980, 3 de maio de 1980, 10 de maio de 1980, 14 de junho de 1980, 28 de junho de 1980, 29 de dezembro de 1984, 9 de janeiro de 1985, 10 de janeiro de 1985, 15 de janeiro de 1985, 21 de janeiro de 1985, 22 de janeiro de 1985, 25 de janeiro de 1985, 1 de março de 1985, 8 Março de 1985,12 de março de 1985, 16 de março de 1985, 8 de junho de 1985, 29 de junho de 1985, 10 de julho de 1985,18 de julho de 1985, 30 de novembro de 1985,10 de dezembro de 1985, 17 de dezembro de 1985, 20 de dezembro de 1985, 21 de dezembro de 1985, 30 de dezembro de 1985, 30 de dezembro de 1989, 19 de janeiro de 1990,13 de janeiro de 1990,1 de dezembro de 1990, 4 de dezembro de 1990, 7 de dezembro de 1990, 29 de dezembro de 1990, 27 de fevereiro de 1995, 6 de março de 1995, de 23 de março de 1995, 29 de março de 1995, 1 de dezembro de 1995, 5 de dezembro de 1995, 7 de dezembro de 1995, 21 de dezembro de 1995, 4 de janeiro de 1999, 12 de janeiro de 1999, 25 de janeiro de 1999, 23 de julho de 2002.

GOLDBERG, Ray Allan. Agribusiness Management for Developing Countries-Latin America, Ballinger Pub. Co., Cambridge, 1974.

; BIRD, Kermit Molyneaux ; ARTHUR, Henry B . The

Technological Front in the Food and Fiber Economy, Technical Paper by the National Advisory Commission on Food and Fiber, Washington, DC, August 1967.

GOODMAN, David ; SORJ, Bernardo ; WILKINSON, John . From Farming to Biotechnology: a Theory of Agro-Industrial Development, Basil Blackwell, Oxford, 1987.

GRAMSCI, Antonio. Cadernos do Cárcere. Volume III, Civilização Brasileira, Rio de Janeiro, 2007.

GROSSMAN, Henryk. Law of the Accumulation and Breakdown, 1929 http://www.marxists.org/archive/grossman/1929/breakdown/ch03.htm. Consulta em 20 de julho de 2011.

GUIMARÃES, Alberto Passos. A Crise Agrária. Paz e Terra, Rio de Janeiro, $3^{\text {a }}$ edição, 1978.

Formação da Pequena Propriedade: Intrusos e Posseiros

(1963), Em Camponeses Brasileiros, Vol. 1, Editora UNESP, São Paulo, 2009. 
HAMPE, Edward C ; WITTENBERG, Merle ; EDDS, Lillian. The Food Industry: Lifeline of America, Cornell University, Ithaca, N.Y., 1980.

HARVEY, David. O Novo Imperialismo. Edições Loyola, São Paulo, 2003.

Editorial, São Paulo, 2010. O Enigma do Capital e as Crises do Capitalismo. Boitempo

HEGEL, G. H. F. Philosophia da Natureza. Impressora Comercial, São Paulo, 1936.

HERMAN, Edward S.; CHOMSKY, Noam. Manufacturing Consent: The Political Economy of the Mass Media. Pantheon Books, New York, 1988.

HOBSBAWM, Eric J. História do Marxismo, Volume 4, Paz e Terra, 1984.

HODGE, Helena Norberg; MERRIFIELD, Todd; GORELICK, Steven. Bringing the Food Economy Home: Local Alternatives to Global Agribusiness. Zed Books, London, 2002.

HURT, Douglas R. Problems of Plenty: The American farmer in the twentieth century. Ivan R. Dee, Chicago, 2002.

IBGE, Censo agropecuário 2006.

http://www.ibge.gov.br/home/estatistica/economia/agropecuaria/censoagro/brasil_2006/ Brasil_censoagro2006.pdf (consulta em 20/02/2010).

KAGEYAMA, Angela ET ALII. O novo padrão agrícola brasileiro: docomplexo rural aos complexos agro-industriais. In DELGADO, Guilherme, Agricultura e Políticas Públicas IPEA. 127. UNICAMP,Campinas (SP), 113 - 223. (1987).

KANT, Immanuel. Crítica à Razão Pura. Abril Cultural, São Paulo, 1980.

KAUTSKY, Karl. A Questão Agrária. Editora Laemmert, Rio de Janeiro, 1968.

KLOPPENBURG, Jack R. First the seed: The political economy of plant biotechnology. Cambridge University Press, Cambridge, 1988.

KONDER, Leandro. A Derrota da Dialética. Expressão Popular, São Paulo, 2009.

KURZ, Robert. O Colapso da Modernização. Paz e Terra, São Paulo, 2004.

Razão Sangrenta: Ensaios sobre a crítica emancipatória da modernidade capitalista e de seus valores ocidentais. Editora Hedra, São Paulo, 2010.

LAMARCHE, Hugues (coord.). A Agricultura Familiar: comparação internacional. Editora da Unicamp, Campinas, 1998.

LAPPÉ, Frances M; COLLINS, Joseph; ROSSET, Peter. World Hunger: Twelve Myths. Grove Press Books, New York, 1998.

LEFEBVRE, Henri. Critique of Everyday Life, Volume II, Verso, London, 2008.

La Presencia y La Ausencia: Contribución a la teoría de las representaciones. Fondo de Cultura Económica, México DF, 1983. 
LÊNIN, Vladimir. Imperialismo Fase Superior do Capitalismo. Centauro Editora, São Paulo, 2008.

Paulo, 1982. O Desenvolvimento do Capitalismo na Rússia. Abril Cultural, São

LOUREIRO, Isabel Maria. Rosa Luxemburg: os dilemas da ação revolucionária, Editora UNESP, São Paulo, 2a edição, 2003.

LÖWY, Michael. As Aventuras de Karl Marx contra o Barão de Münchhausen. Editora Cortez, São Paulo, 2009.

LUKÁCS, Georg. História e Consciência de Classe, Martins Fontes, São Paulo, 2003.

LUXEMBURG, Rosa. A Acumulação do Capital. Editora Abril Cultural, São Paulo, 1985.

MANDEL, Ernest. A Crise do Capital. Editora da Unicamp, Campinas, 1990.

MARTINS, Mônica Dias. Açúcar no Sertão: A ofensiva capitalista no Nordeste do Brasil, Annablume, São Paulo, 2008.

2004.

(Org). O Banco Mundial e a Terra, Editora Viramundo, São Paulo,

MARX, Karl. O Capital. Livros I, II e III. Editora Abril Cultural (Série “Os Economistas"), São Paulo, 1983.

Capital, Volume I, Vintage Books, New York, 1977.

. Contribuição à Crítica da Economia Política, Ed. Martins Fontes, São

Paulo, 2003.

Elementos Fundamentales para la Crítica de la Economía Política

(Grundrisse). Siglo XXI, México, 1997.

Miséria da Filosofia. Expressão Popular, São Paulo, 2009.

; ENGELS, Friedrich. A Ideologia Alemã, Ed. Martins Fontes, São

Paulo, 2007.

McMICHAEL, Philip. Global Food Politics. In Hungry for Profit: The Agribusiness Threat to Farmers, Food, and the Environment. Monthly Review Press, New York, 2000.

MENDONÇA; Maria L.; PITTA; Fábio T.; XAVIER, Carlos V. A Agroindústria Canavieira e a Crise Econômica Mundial. Editora Outras Expressões, São Paulo, 2012. http://www.social.org.br/relatorioagrocombustiveis2012.pdf.

MÉSZÁROS, István. O Poder da Ideologia. Boitempo Editorial, São Paulo, 2004.

2009. . A Crise Estrutural do Capital. Boitempo Editorial, São Paulo, 
MINKOWISK, H. Espaço e Tempo, In: A. Einstein. Fundação Calouste Gulbendian, Lisboa, 1989.

MORISSAWA, Mitsue. A História da Luta pela Terra e o MST, Expressão Popular, São Paulo, 2001.

MÜLLER, Geraldo. Complexo Agroindustrial e Modernização Agrária. SP, Editora Hucitec, São Paulo, 1989.

NEVES, Marcos F. Caracterizando e Quantificando Cadeias Produtivas: O Método do Pensa. Em Agronegócio do Brasil, Editora Saraiva, São Paulo, SP, 2005.

NEWTON, Isaac. Definições, Axiomas ou Leis do Movimento. Edusp, São Paulo, 1990.

O Estado de São Paulo, edição de 05/07/2005. Consulta em 20/01/2009.

O Estado de São Paulo, 6/12/2006, p. A2, http://textospra.blogspot.com/2006/12/165polticas-para-o-futuro-da.html. Consulta em 2/03/2012.

O Estado de S. Paulo, 26/09/2012.

http://www.noticiasagricolas.com.br/noticias/agronegocio/111356-harmonizacaoagroindustrial--por-decio-zylbersztajn.html. Consulta em 12/11/2012.

OLIVEIRA, Ariovaldo U. O Modo de Produção Capitalista. São Paulo, Ed. Ática, 1986.

. A Inserção do Brasil no Capitalismo Monopolista Mundial.

Em Ross, Jurandyr - Geografia do Brasil. SP, EDUSP, 1998.

Geografia e os Movimentos Sociais, Conferência

Perspectiva Agrária, Unioeste Colegiados de Geografia, n. 3, 2007.

. Agricultura e Indústria no Brasil. CAMPO-TERRITÓRIO:

Revista de Geografia Agrária, v. 5, n. 10, p. 5-64, agosto 2010.

; MARQUES, Marta Inez Medeiros (orgs.). O Campo no

Século XXI, Editora Casa Amarela, São Paulo, 2004.

OLIVEIRA, Francisco de. Crítica à Razão Dualista. Boitempo Editorial, São Paulo, 2003.

PAOLIELlO, Renata M. Posse da Terra e Conflitos Sociais no Campo.

PPGAS/UNICAMP, Campinas, 1992.

PATEL, Raj. The Long Green Revolution. Journal of Peasant Studies, 40:1, 1-63, Routledge, London, 2013.

PAULINO, Eliane T; FABRINI João E (org.). Campesinato e Territórios em Disputa. Expressão Popular, São Paulo, 2008.

PERELMAN, Michael. Farming for Profit in a Hungry World. Allanheld, Osmun

Publishers, Montclair, 1979. 
PITTA, Fábio T. - Modernização Retardatária e agroindústria sucroalcooleira paulista: o Proálcool como reprodução fictícia do capital em crise. Dissertação de Mestrado em Geografia Humana, FFLCH-USP, São Paulo, 2011.

; MENDONÇA, Maria Luisa. O Etanol e a Reprodução do Capital em Crise. Revista Agrária, v. 13, p. 4-33, Universidade de São Paulo (USP), 2012.

POSTONE, Moishe. Time, Labor and Social Domination: a Reinterpretation on Marx Critical Theory. Cambridge University Press, 1993.

PRADO Jr., Caio. História Econômica do Brasil. Editora Brasiliense, São Paulo, 1970. edição, 2007. . A questão agrária no Brasil. Editora Brasiliense, São Paulo, $5^{\mathrm{a}}$.

PROCHNIK, Victor. Cadeias Produtivas e Complexos Industriais. Em Firma, Indústria e Mercados, HASENCLEVER, L. \& KUPFER, D. Ed. Campus, São Paulo, 2002.

RAWLINS, N Omri. Introduction to Agribusiness. Englewood Cliffs, New Jersey, 1980.

ROSS, Robert L. Mission Possible: The Story of the Latin American Agribusiness Development Corporation (LAAD). Transaction Publishers, New Brunswick, 2000.

ROSSON, C Parr. International Marketing for Agribusiness: Concepts and Applications, GEMS, Global Entrepreneurship Management Support, 1994.

ROY, Ewell Paul. Exploring Agribusiness, Interstate Printers \& Publishers, Danville, 1967.

SILVA, José Graziano da. O Novo Rural Brasileiro, Revista Nova Economia, Belo Horizonte, Vol. 7, n. 1, p.43-81, maio 1997.

SILVA, Valter Israel. A lógica da Economia Camponesa e Elementos para o Debate sobre o Campesinato. Mimeo do autor. Movimento dos Pequenos Agricultores (MPA), 2011.

SHIVA, Vandana. The Violence of the Green Revolution. The Other India Press, Goa, India, 1991.

SOLOMON, Norman. War Made Easy: How presidents and pundits keep spinning us to death, John Wiley \& Sons, Inc., New Jersey, 2005.

STÉDILE, João P. (Org.). A Questão Agrária Hoje, Editora da UFRGS, Porto Alegre, 1994.

Paulo, 2005. . (Org.) - A Questão Agrária no Brasil, Vol. 3, Expressão Popular, São

THOMPSON, E. P. Senhores e Caçadores. Paz e Terra, Rio de Janeiro, 1987.

VELHO, Otávio. O Conceito de Camponês e sua Aplicação à Análise do Meio Rural Brasileiro. Em Camponeses Brasileiros, Vol. 1, Editora UNESP, São Paulo, 2009. 
VERGOPOULOS, Kostas. Capitalismo disforme: o caso da agricultura no capitalismo. Em A Questão Agrária e o Capitalismo, Paz e Terra, Rio de Janeiro,1977.

VOGELER, Ingolf. The Myth of the Family Farm: Agribusiness Dominance of U.S. Agriculture. Westview Press, Boulder, Colorado, 1981.

WALKER, Richard A. The Conquest of Bread: 150 Years of Agribusiness in California. The New Press, New York, 2004.

WELCH, Clifford. Agribusiness: Uma breve história do modelo norteamericano. Anais do X Encontro de Geógrafos da América Latina, Universidade de São Paulo, 2005.

; MALAGODI, Edgard; CAVALCANTI, Josefa; WANDERLEY, Maria N. (Org.), Camponeses Brasileiros, Vol. 1, Editora UNESP, São Paulo, 2009.

WOLF, Eric R. Guerras Camponesas do Século XX. Global Editora, São Paulo, 1984.

WOOLVERTON, Michael, Ed. Agribusiness: An International Journal, John Wiley \& Sons, New York, Vol. 1, Number 1, Spring 1985.

WRIGHT, Angus. The Death of Ramón González: The Modern Agricultural Dilemma. University of Texas Press, Austin, 1990.

XAVIER, Carlos Vinicius; PITTA, Fábio T; MENDONÇA, Maria Luisa. Monopólio na Produção de Etanol no Brasil: A fusão Cosan-Shell. São Paulo, Rede Social de Justiça e Direitos Humanos, 2011. http://www.social.org.br.

ZYLBERSZTAJN. D. À Fogueira com os Livros de Agronegócios. Em Agronegócio do Brasil, Editora Saraiva, São Paulo, SP, 2005. 